Gustavo Henrique Siqueira

\title{
Almofada de apoio de compósito de cimento para ligações em concreto pré-moldado
}

Dissertação apresentada à Escola de Engenharia de São Carlos, da Universidade de São Saulo, como parte dos requisitos para obtenção do Título de Mestre em Engenharia de Estruturas

Orientador: Prof. Tit. Mounir Khalil El Debs 

Candidato: Engenheiro GUSTAVO HENRIQUE SIQUEIRA

Dissertação defendida e julgada em 30/03/2007 perante a Comissão Julgadora:

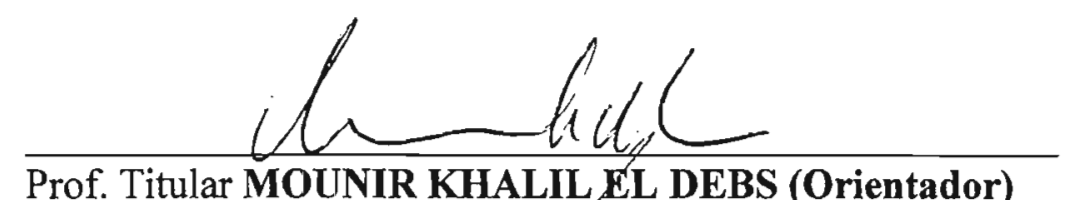

(Escola de Engenharia de São Carlos/USP)

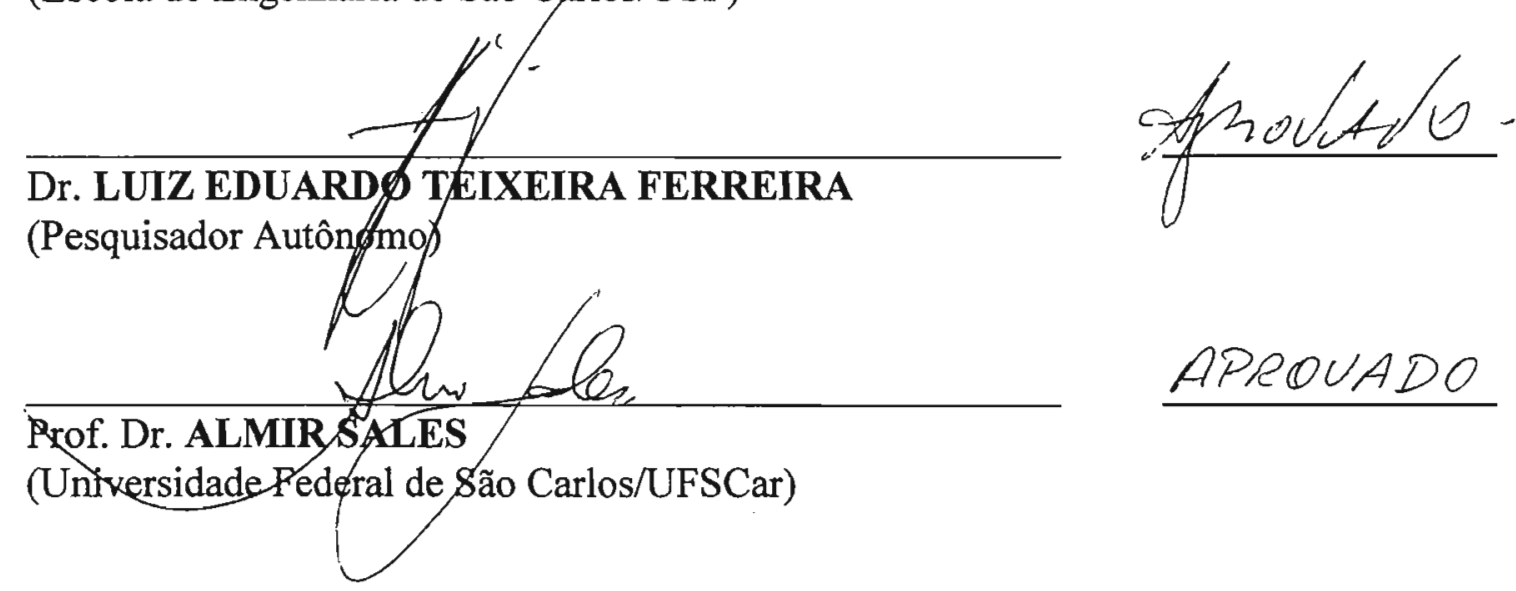

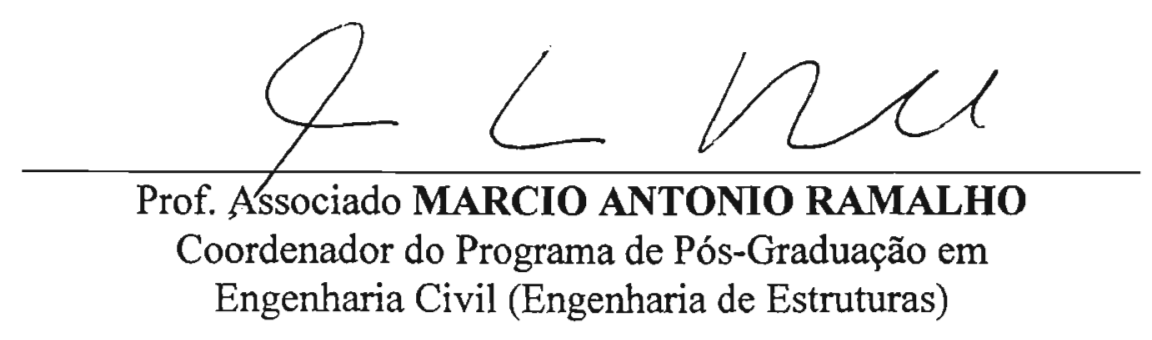

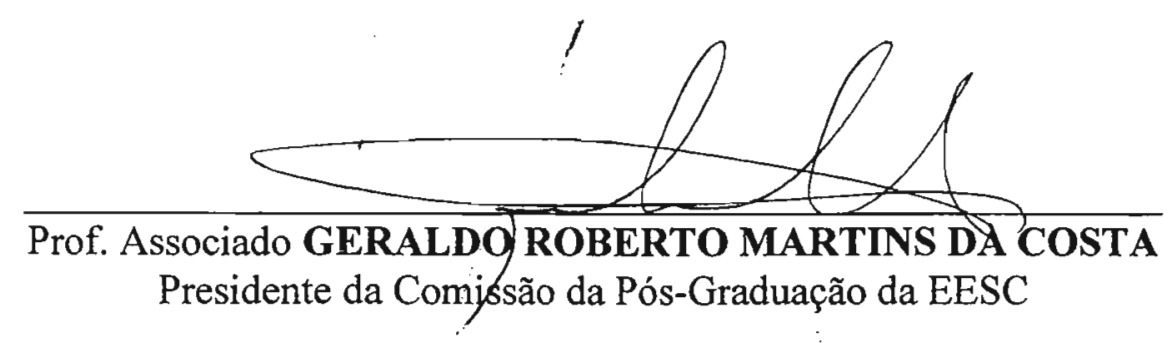



À Deus, pela proteção em mais essa etapa. Aos meus pais, José Carlos e Adelina, e irmãos pelo amor e carinho incondicionais durante todos esses anos. À minha noiva, Ana Paula, pelo amor e compreensão durante a realização deste trabalho 



\section{Agradecimentos}

À Deus, pelo amor e proteção durante todas as etapas de minha vida.

Aos meus pais, José Carlos e Adelina, meus irmãos Fábio, Júnior e Érica, minhas cunhadas Vanessa e Luciana, meu avô, João Siqueira, pessoa muito simples mas de sabedoria ímpar e, à minha noiva, Ana Paula e sua família, que sempre me deram apoio e amor durante esta fase.

Aos meus grandes amigos da graduação, a galerinha mais ou menos, sem vocês a faculdade de engenharia não teria a menor graça.

Ao meu orientador, Mounir Khalil El Debs, pela confiança, paciência, dedicação, amizade e os preciosos ensinamentos desde a iniciação científica.

À professora Aline Barboza, pelo apoio e ajuda durante toda minha iniciação científica e pelo incentivo durante todo o mestrado.

Aos funcionários do Laboratório pela ajuda e pelo profissionalismo na montagem e execução de todos os ensaios desta pesquisa.

À todos os professores e funcionários do SET, que contribuíram para a conclusão deste trabalho.

Aos amigos Paulino, Vinícius, Guilherme Said, Estevam, Guilherme David e Eric, com os quais tive a oportunidade de passar os momentos de lazer e descontração durante esses anos.

À todos os membros da sala 03, Danilo, Kenneth, João, Antônio e Rafael e os amigos caçulas que fiz neste último ano de mestrado. 
Aos grandes amigos que fiz no início do mestrado, Filipe, Denis, André, Saulo, Edmar, Gláucia, Iara, Karenina, Lívia, Ronaldo, Tiago, Elian, Alice, Ricardo, Danusa, Thais, Othavio, Walter, Eduardo, Gustavo, Edson, Paccola, Claudius e Luciano, pois todos tiveram uma grande e importante participação em minha vida durante esse período.

De forma especial agradecer a dois amigos que conheci no início do curso de mestrado, Luiz Carlos e Marlos, que sempre estiveram presentes em todos os momentos dessa conquista e me ajudaram muito durante esse período.

À CNPq pelo apoio financeiro e as empresas Fitesa e Ciminas pela doação de materiais para a realização desta pesquisa. 


\section{Sumário}

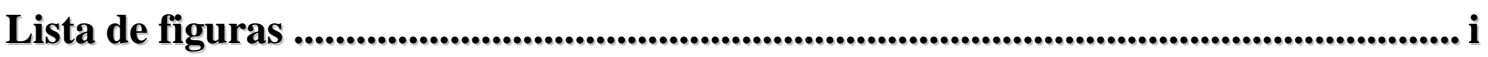

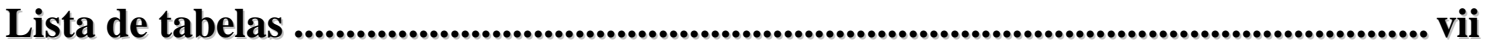

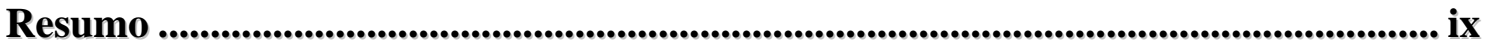

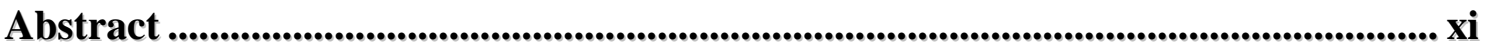

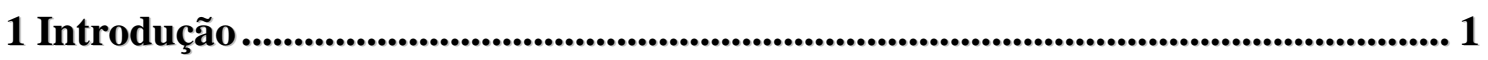

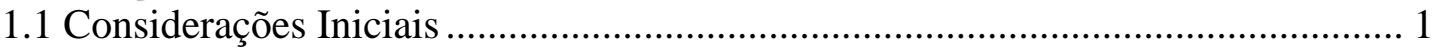

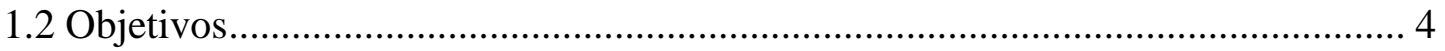

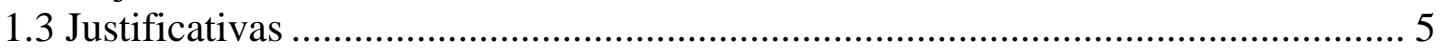

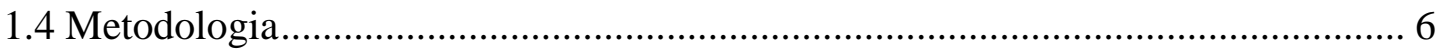

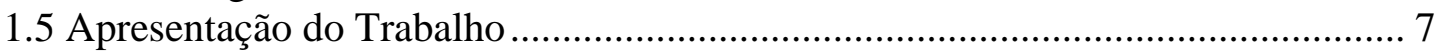

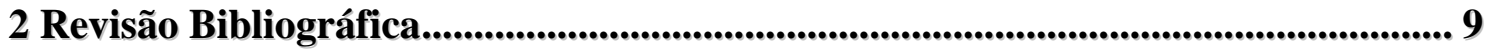

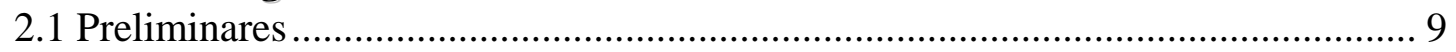

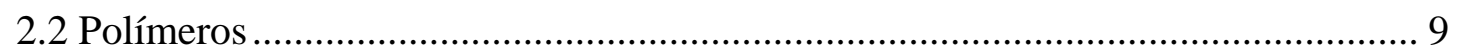

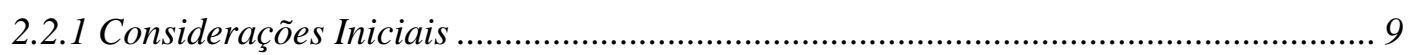

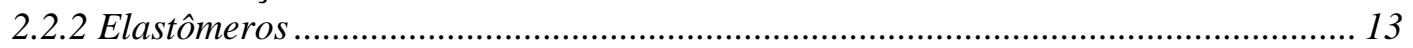

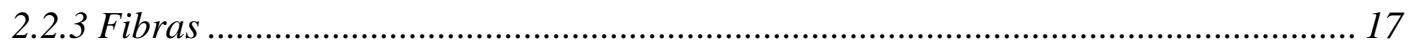

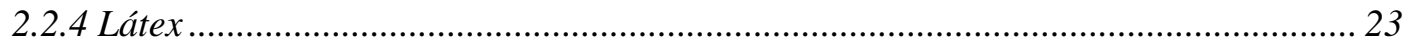

2.3 Argamassas modificadas com látex estireno-butadieno..................................... 31

2.4 Almofadas de apoio de compósito de cimento ...................................................... 36

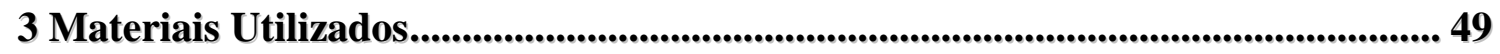

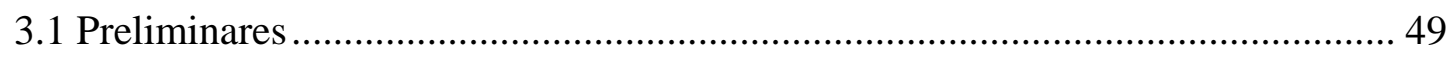

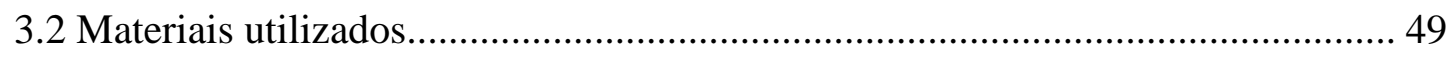

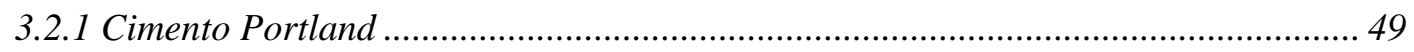

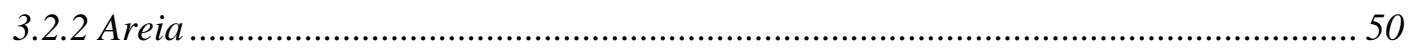

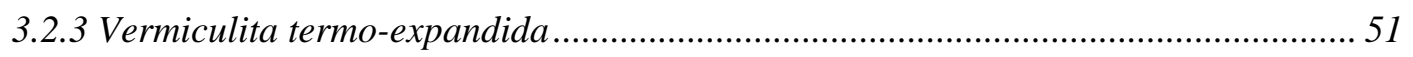

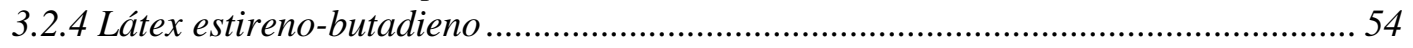

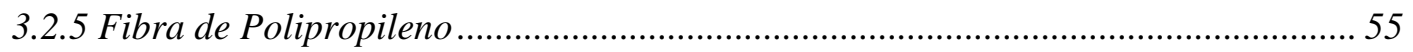

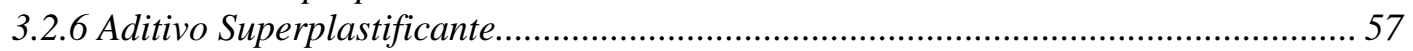

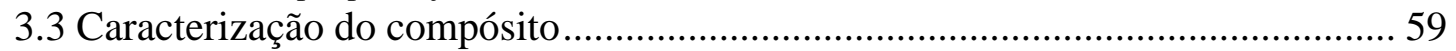

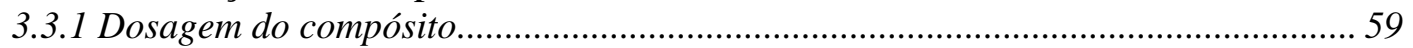

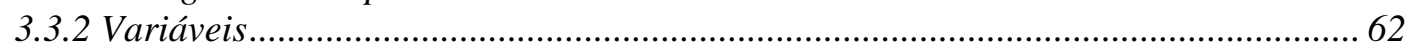

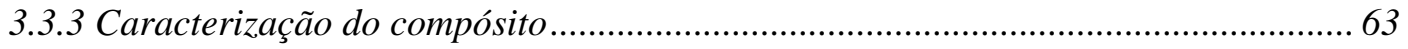




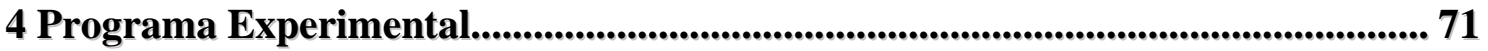

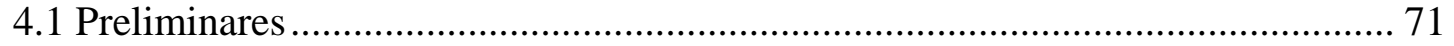

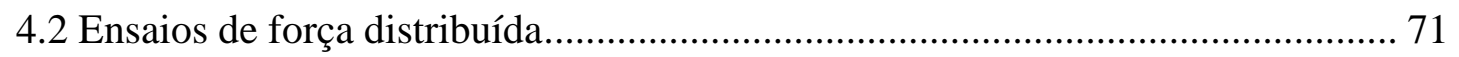

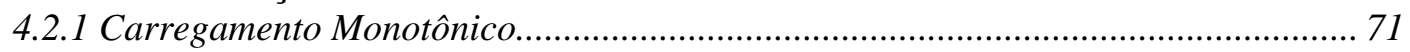

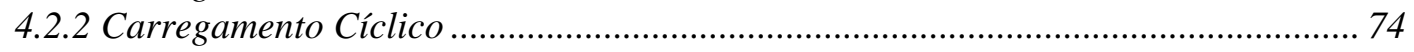

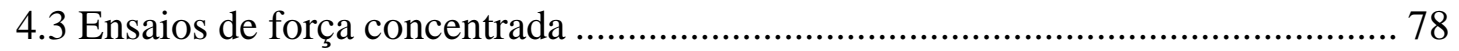

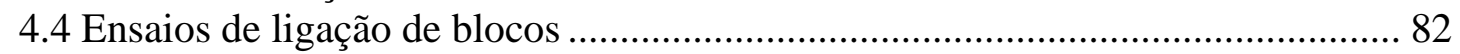

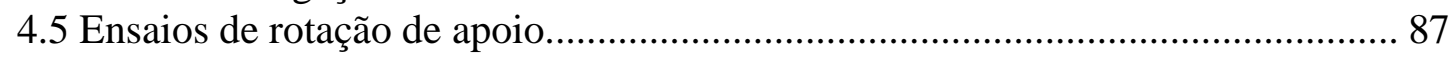

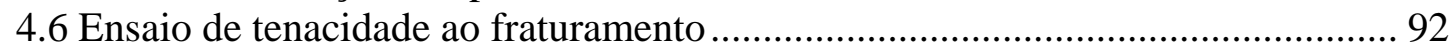

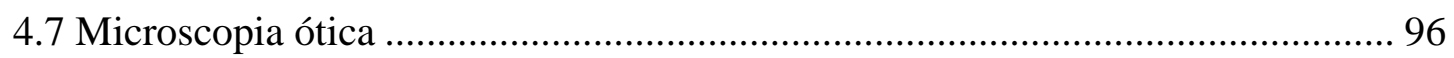

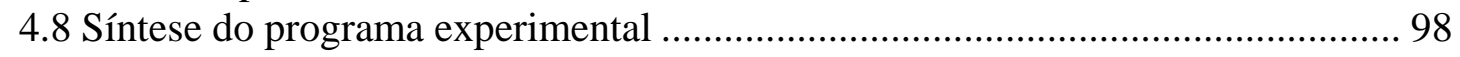

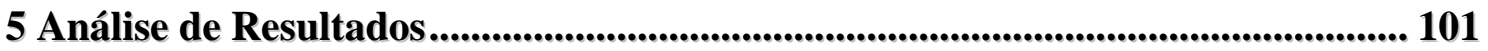

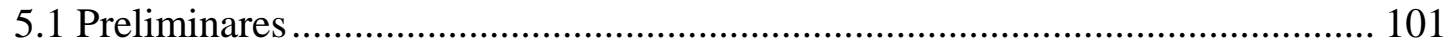

5.2 Resistências e módulo de deformação.................................................................. 101

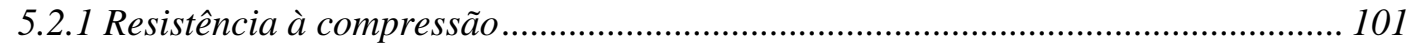

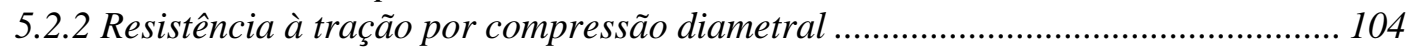

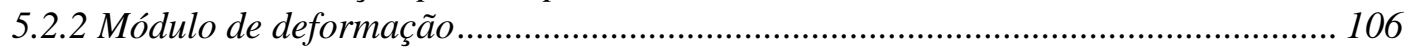

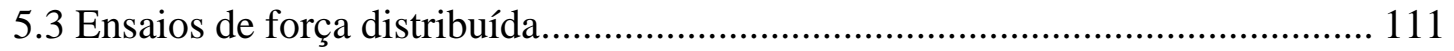

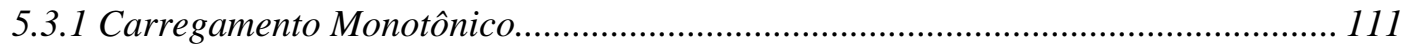

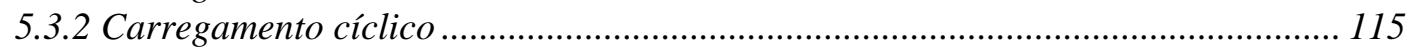

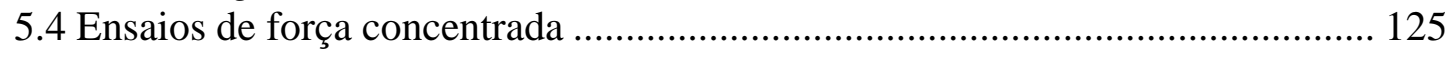

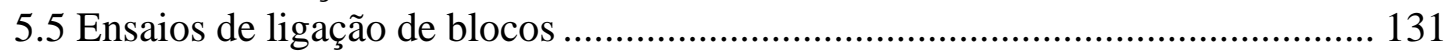

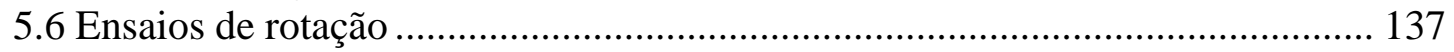

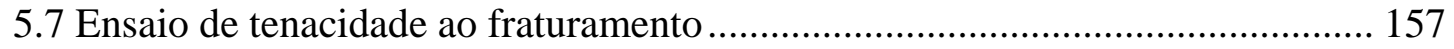

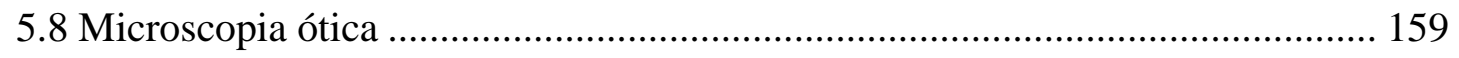

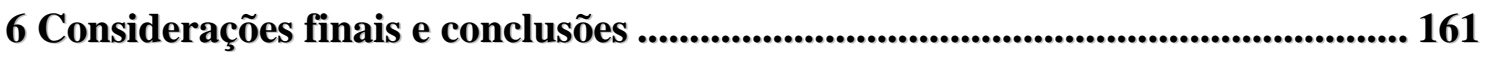

Referências Bibliográficas ............................................................................................ 165 


\section{Lista de figuras}

Figura 1.1: Esquema de ligação viga-pilar................................................................. 3

Figura 1.2: Almofadas de apoio de diferentes formatos. ......................................... 3

Figura 2.1: Influência do Grau de Cristalinidade e do Peso Molecular sobre as características físicas do Polietileno (CALLISTER JR., 2000).

Figura 2.2: Representação esquemática de moléculas de cadeias de polímeros com ligações cruzadas (a) em um estado sem tensão e (b) durante deformação elástica sob aplicação de tensão de tração (CALLISTER JR., 2000)....

Figura 2.3: Reação de vulcanização de um elastômero (CALLISTER JR., 2000)....... 16

Figura 2.4: Curvas tensão-deformação até um alongamento de $600 \%$ para as borrachas naturais vulcanizada e não-vulcanizada (CALLISTER JR., 2000).

Figura 2.5: Modelo idealizado de formação do concreto de cimento polímero (OHAMA, 1998 apud. PERUZZI, 2002).

Figura 2.6: Modelo idealizado do processo de formação do filme de polímero na partícula de cimento (STORTE, 1991 apud. PERUZZI, 2002)......

Figura 2.7: Esquema do ensaio de ligação pilar-pilar realizado por BARBOZA (2002).

Figura 2.8: a) Máquina de Ensaios e b) Aplicação de carga na almofada (MONTEDOR, 2004).

Figura 2.9: Ensaio de carga localizada.

Figura 2.10: Resultados dos ensaios de compressão em corpos-de-prova cilíndricos_(MONTEDOR, 2004).

Figura 2.11: Resultados dos ensaios de tração por compressão diametral em corpos-de-prova cilíndricos (MONTEDOR, 2004)

Figura 2.12: Resultados dos ensaios de módulo de elasticidade em corpos-de-prova cilíndricos (MONTEDOR, 2004). 45

Figura 2.13: Resultados dos ensaios de rigidez de placa (MONTEDOR, 2004). 45

Figura 2.14: Resultados dos ensaios de ligação de blocos com almofadas de $10 \mathrm{~mm}$ de espessura e $0 \%$ de inclinação (MONTEDOR, 2004). 46

Figura 2.15: Ligação Viga-Pilar estudada por BALDISSERA (2006). 47

Figura 2.16: Ligação Viga-Pilar estudada por SOUZA (2006). 47

Figura 3.1: Curva Granulométrica da Areia utilizada nos ensaios..... 
Figura 3.2: Vermiculita: natural, expandida e partícula expandida. .......................... 52

Figura 3.3: Curva granulométrica da vermiculita (Fonte: MONTEDOR, 2004)......... 54

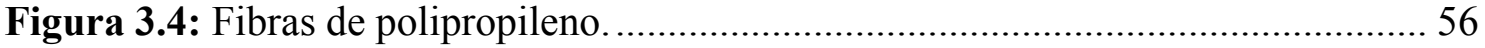

Figura 3.5: (a) Introdução de látex á mistura de cimento, areia e vermiculita;

(b) consistência da mistura antes da introdução de água e superplastificante;

(c) consistência melhorada após a introdução da água e superplastificante;

(d) introdução da fibra de polipropileno.

Figura 3.6: (a)Batedeira industrial utilizada na pesquisa; (b) introdução de látex á mistura de cimento, areia e vermiculita; (c) consistência melhorada após a introdução da água e superplastificante; (d) introdução da fibra de polipropileno.

Figura 3.7: (a) Consistência da argamassa; (b) compactação da argamassa ao molde.

Figura 3.8: (a) e (b): Esquema do ensaio de compressão simples............................... 66

Figura 3.9 (a) e (b): Esquema do ensaio de tração por compressão diametral. ............. 67

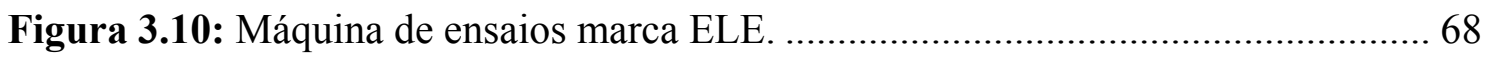

Figura 3.11: (a) Corpo-de-prova com transdutor de deslocamento; (b) esquema

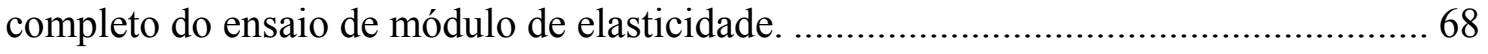

Figura 3.12: Gráfico para determinação do módulo de elasticidade.............................. 69

Figura 4.1: (a) Almofada do compósito; (b) e (c) Esquemas do ensaio de carregamento monotônico; (d) Máquina de ensaios.................................................... 73

Figura 4.2: Gráfico força $x$ deslocamento para duas amostras de almofada................. 74

Figura 4.3: Sistema de aquisição de dados System 6000 ............................................. 75

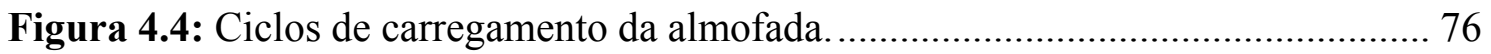

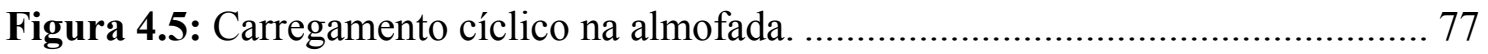

Figura 4.6: Carregamento cíclico na almofada após a retirada de pontos

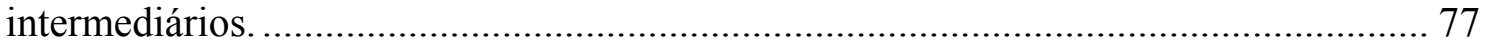

Figura 4.7: Exemplo de ensaio de almofada com 1200 ciclos de carregamento. ......... 78

Figura 4.8: Exemplo de ensaio de almofada com 1200 ciclos após retirada de pontos intermediários.

Figura 4.9: (a) Esquema frontal ensaio de carga concentrada (medidas em $\mathrm{cm}$ );

(b) Esquema tridimensional do ensaio.

Figura 4.10: (a) Máquina MTS utilizada nos ensaios de carga localizada;

(b) Vista ampliada do ensaio de afundamento.

Figura 4.11: Curvas força $x$ deslocamento para o traço V10PP4,0L30 ....................... 81

Figura 4.12: Curvas média força $x$ deslocamento para o traço V10PP4,0L30 ............ 82

Figura 4.13: Esquema dos ensaios de ligação de blocos............................................ 83

Figura 4.14: Esquema das rugosidades e colocação dos blocos para ensaio. ................ 83

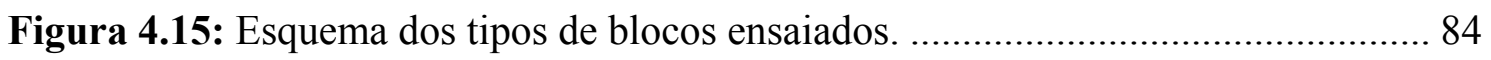

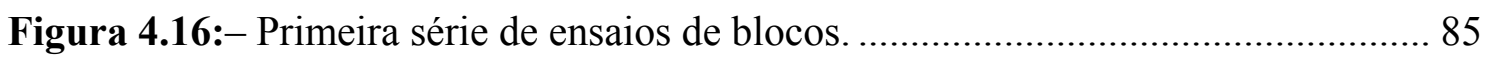


Figura 4.17: Segunda série de ensaios de blocos. 86

Figura 4.18: (a) Ensaio de blocos lisos sem almofada; (b) blocos para ensaio com rugosidade de $1,5 \mathrm{~mm}$ sem almofada. 87

Figura 4.19: Esquema básico do ensaio de rotação. 87

Figura 4.20: Esquema íntegro do ensaio de rotação. 88

Figura 4.21: Detalhes do ensaio de rotação. 89

Figura 4.22: Convenção adotada para os ensaios. 90

Figura 4.23: (a) e (b) Descolamento da extremidade da chapa em relação a superfície da almofada. 91

Figura 4.24: Relógios com bases magnéticas posicionados sobre base metálica. 92

Figura 4.25: Esquema do ensaio de tenacidade ao fraturamento à flexão em três pontos

Figura 4.26: Deflexões importantes ao ensaio de tenacidade ao fraturamento. 94

Figura 4.27: (a) Apoio móvel; (b) clip-gauge de medição da abertura da fissura; (c) detalhe do ensaio sem o LVDT de monitoração dos deslocamentos verticais; (d) esquema completo do ensaio. 96

Figura 4.28: (a) Colocação da argamassa na forma; (b) acabamento superficial da almofada. 97

Figura 4.29: Esquema da retirada de amostra das almofadas. .................................. 98

Figura 5.1: Gráfico comparativo para o ensaio de compressão simples. 102

Figura 5.2: Comparação dos resultados de resistência à compressão para 30\% de látex. 104

Figura 5.3: Resistência a tração por compressão diametral. 105

Figura 5.4: Comparação dos resultados de resistência à tração para 30\% de látex 106

Figura 5.5: Curva tensão $x$ deformação. 107

Figura 5.6: Módulo de elasticidade do compósito. 107

Figura 5.7: Comparação de resultados de módulo de elasticidade. 108

Figura 5.8: Relação entre módulos de elasticidade secante e tangente e resistência a compressão.

Figura 5.9: Rigidez das placas. 113

Figura 5.10: Relação entre Módulo de deformação e rigidez das placas. 114

Figura 5.11: Comparação das rigidezes de almofadas do compósito e almofada de neoprene.

Figura 5.12: Almofadas do traço V5PP4,5L30 com 200 ciclos de carregamento...... 117

Figura 5.13: Almofadas do traço V10PP4L30 com 200 ciclos de carregamento. ....... 117

Figura 5.14: Almofadas do traço V15PP3,5L30 com 200 ciclos de carregamento. ... 118

Figura 5.15: (a) Almofadas do traço V10PP4L30 antes do ensaio;

(b) almofada do traço V10PP4L30 após o ensaio. 
Figura 5.16: Almofada do traço V5PP4,5L30 com 1200 ciclos de carregamento...... 120

Figura 5.17: Almofada do traço V10PP4L30 com 1200 ciclos de carregamento....... 121

Figura 5.18:- Almofada do traço V15PP3,5L30 com 1200 ciclos de carregamento.. 121

Figura 5.19: Comparação entre 50 e 200 ciclos de carga para o traço V10PP4L30... 123

Figura 5.20: Curvas das 10 amostras do ensaio de carga localizada para o traço V5PP4,5L30.

Figura 5.21: Curva média das amostras do ensaio de carga localizada para o traço V5PP4,5L30.

Figura 5.22: Curvas médias das amostras dos ensaios de carga localizada................ 128

Figura 5.23: Evolução do carregamento nas tiras do compósito................................. 129

Figura 5.24: Ruptura das tiras da almofada por tração. .............................................. 130

Figura 5.25: Gráfico do produto afundamento $x$ força. ............................................ 131

Figura 5.26: Blocos da primeira série de ensaios........................................................ 133

Figura 5.27: Blocos da segunda série de ensaios. ..................................................... 134

Figura 5.28: Conjunto dos ensaios de ligação de blocos. .......................................... 135

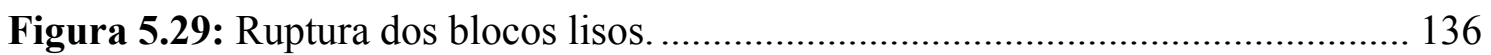

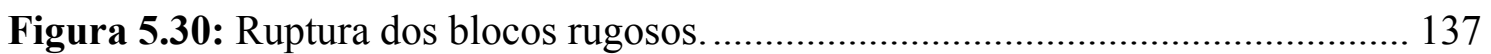

Figura 5.31: Planta de posicionamento dos relógios do ensaio de rotação.................. 138

Figura 5.32: Deslocamento médio para o traço V5PP4,5L30 e=10mm. .................... 139

Figura 5.33: Rotações nos apoios para o traço V5PP4,5L30 e=10mm....................... 140

Figura 5.34: Rotações médias dos apoios para o traço V5PP4,5L30 e =10mm. ......... 140

Figura 5.35: Deslocamento médio para o traço V5PP4,5L30 e=20mm. .................... 141

Figura 5.36: Rotações nos apoios para o traço V5PP4,5L30 e=20mm....................... 142

Figura 5.37: Rotações médias dos apoios para o traço V5PP4,5L30 e=20mm. ......... 142

Figura 5.38: Deslocamento médio para o traço V10PP4L30 e =10mm. ..................... 143

Figura 5.39: Rotações nos apoios para o traço V10PP4L30 e=10mm....................... 144

Figura 5.40: Rotações médias dos apoios para o traço V10PP4L30 e=10mm. .......... 144

Figura 5.41: Deslocamento médio para o traço V10PP4L30 e=20mm. ..................... 145

Figura 5.42: Rotações nos apoios para o traço V10PP4L30 e=20mm........................ 146

Figura 5.43: Rotações médias dos apoios para o traço V10PP4L30 e=20mm. .......... 146

Figura 5.44: Deslocamento médio para o traço V15PP3,5L30 e=10mm. .................. 147

Figura 5.45: Rotações nos apoios para o traço V15PP3,5L30 e=10mm.................... 148

Figura 5.46: Rotações médias dos apoios para o traço V15PP3,5L30 e=10mm. ....... 148

Figura 5.47: Deslocamento médio para o traço V15PP3,5L30 e=20mm. ................. 149

Figura 5.48: Rotações nos apoios para o traço V15PP3,5L30 e=20mm.................... 150

Figura 5.49: Rotações médias dos apoios para o traço V15PP3,5L30 e=20mm. ....... 150 
Figura 5.50: Descolamento entre a chapa metálica e almofada de $20 \mathrm{~mm}$. 151

Figura 5.51: Fissuras após ensaio de rotação em almofada de $20 \mathrm{~mm}$. 152

Figura 5.52: Comparação de rotações para as almofadas de 10mm de espessura...... 153

Figura 5.53: Viga de ponte rolante do laboratório de estruturas da EESC/USP......... 155

Figura 5.54: Viga de concreto armado idealizada.................................................. 155

Figura 5.55: Curvas de deslocamento vertical da linha de carga do compósito. ......... 157

Figura 5.56: Foto de uma das extremidades da superfície das almofadas do compósito. 159

Figura 5.57: Foto da região central da superfície das almofadas do compósito. 160 



\section{Lista de tabelas}

Tabela 2.1: Temperaturas de Transição Vítrea e de Fusão para alguns tipos de Polímeros (CALLISTER JR., 2000).

Tabela 2.2: Características importantes para cinco elastômeros comerciais (CALLISTER JR., 2000).

Tabela 2.3: Propriedades de algumas fibras - Fonte: TEZUKA (1989). 20

Tabela 2.4: Ligações viga-pilar estudadas por MIOTTO (2002). 37

Tabela 2.5: Misturas para ensaios de caracterização do material (MONTEDOR, 2004). 40

Tabela 2.6: Variáveis analisadas. 41

Tabela 2.7: Traço de referência. 41

Tabela 2.8: Legenda dos materiais. 41

Tabela 2.9: Ensaios de ligação de blocos (MONTEDOR, 2004)................................... 43

Tabela 3.1: Características do cimento utilizado (Fonte: HOLCIM S.A.).....................50

Tabela 3.2: Propriedades do látex estireno-butadieno (Rhodia do Brasil)..................... 54

Tabela 3.3: Propriedades das fibras de polipropileno (Fonte: Fitesa S.A.)................... 56

Tabela 3.4: Características do Glenium 51 (Fonte: Catálogo Técnico do Fabricante). 59

Tabela 3.5: Traço de referência em massa .................................................................. 59

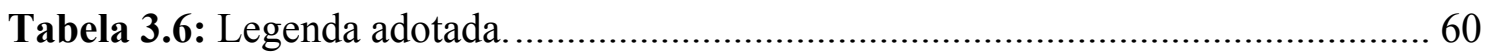

Tabela 3.7: Consumos de cimento para os traços estudados........................................ 61

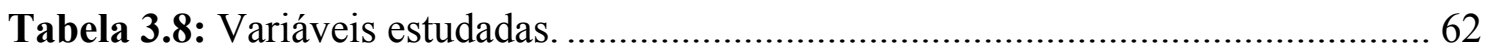

Tabela 4.1: Traços estudados no ensaio de carregamento monotônico.......................... 72

Tabela 4.2: Traços estudados no ensaio de carga localizada........................................ 81

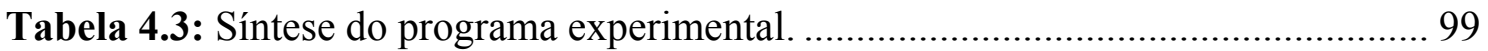

Tabela 5.1: Resultados do ensaio de compressão simples para os traços estudados... 102

Tabela 5.2: Resultados do ensaio tração para os traços estudados.............................. 104

Tabela 5.3: Relações entre resistências e módulo de elasticidade............................... 109

Tabela 5.4: Rigidez das placas dos traços estudados. ................................................. 112

Tabela 5.5: Relações entre módulo de elasticidade e rigidez.................................... 113

Tabela 5.6: Traços estudados nos ensaios de carregamento cíclicos. ......................... 116 
Tabela 5.7: Comparação de valores de afundamentos para diferentescarregamentos. 124

Tabela 5.8: Comparação de valores de rigidezes para diferentes carregamentos. ...... 124

Tabela 5.9: Traços estudados no ensaio de carga localizada....................................... 125

Tabela 5.10: Resistências dos blocos da $1^{\mathrm{a}}$ série de ensaios. ..................................... 132

Tabela 5.11: Resistências dos blocos da $2^{\mathrm{a}}$ série de ensaios. .................................... 133

Tabela 5.12: Tensões médias para o ensaio de tenacidade flexional. ........................ 158 


\section{Resumo}

SIQUEIRA, G.H. (2007). Almofada de apoio de compósito de cimento para ligações em concreto pré-moldado. 169p. Dissertação (Mestrado) - Escola de Engenharia de São Carlos, Universidade de São Paulo, São Carlos, 2007.

Esta pesquisa apresenta um estudo de uma argamassa modificada para uso como elemento de ligação entre elementos de concreto pré-moldado. A argamassa utilizada nesta pesquisa é obtida pela introdução de látex estireno-butadieno (SB) e fibras de polipropileno a uma argamassa de cimento e areia. Estas adições modificam suas propriedades mecânicas, proporcionando o aumento da deformabilidade por diminuição do módulo de elasticidade do compósito, conferindo-lhe características favoráveis ao uso como elemento de apoio para elementos pré-moldados de concreto. Foram realizados ensaios de caracterização do compósito por meio da obtenção das resistências à compressão e à tração e, do módulo de elasticidade para corpos-de-prova cilíndricos com 50mm de diâmetro com 100mm de altura. Ensaios de capacidade de deformação, capacidade de rotação e capacidade de acomodação de imperfeições e distribuição das tensões foram realizados em almofadas de $150 \mathrm{~mm}$ x $150 \mathrm{~mm}$ com espessura de $10 \mathrm{~mm}$. Os resultados mostraram que o material possui boa capacidade de se deformar em níveis de tensão da ordem de 10 a 20MPa mantendo sua resiliência. Valores de rotações entre 0,01 e 0,02rad foram obtidos nos ensaios, sendo estas maiores que os valores necessários para a maioria dos casos convencionais de projeto. Na acomodação e distribuição das tensões, a presença das almofadas promoveu uma melhora de 25\% no desempenho de ligações submetidas à compressão uniforme, com rugosidades de $1,0 \mathrm{~mm}$.

Palavras-chave: Almofadas de apoio, Fibras de Polipropileno; Látex Estirenobutadieno; Ligações; Estruturas de concreto pré-moldado. 



\section{Abstract}

SIQUEIRA, G.H. (2007). Bearing pad of cement composite for connections in precast concrete. 169p. M.Sc. Dissertation - Escola de Engenharia de São Carlos, Universidade de São Paulo, São Carlos, 2007.

This research presents a study of a mortar modified to use as bearing pad between precast concrete elements. The mortar used in this research is achieved by the introduction of styrene-butadiene latex (SB) and polypropylene fibers into a cement mortar and sand, modifying their mechanical properties, as increase of the potential deformation by decrease of the composite modulus of elasticity, providing favorable characteristics to the use as bearing pad for precast concrete elements. Cylindrical samples of $50 \mathrm{~mm}$ of diameter with height of $100 \mathrm{~mm}$ were molded and tested to determination the compressive and the tensile strength and also the modulus of elasticity of the composite. Compression tests with cushions of $150 \mathrm{~mm} \times 150 \mathrm{~mm}$ of base with thickness of $10 \mathrm{~mm}$ were done to determinate the deformation capacity, rotation capacity and capacity of accommodation of imperfections and distribution of the stresses between precast elements. The results showed that the material has a capacity to deform in levels of tension from 10 to $20 \mathrm{MPa}$ maintaining his resilience. Values of rotations among 0,01 and 0,02rad were obtained, being these larger ones than the necessary values for most of the conventional cases of project. In the accommodation and distribution of the stresses, the presence of the bearing pad promoted an improvement of $25 \%$ in the strength of connections subject to uniform compressive stresses, with surface irregularities of $1,0 \mathrm{~mm}$.

Keywords: Bearing pad; Polypropylene fibers; Styrene-butadiene latex; Connections; Precast concrete structures. 



\section{Introdução}

\subsection{Considerações Iniciais}

As ligações entre elementos de concreto pré-moldado, geralmente, são a parte mais importante do projeto deste tipo de sistema estrutural. Elas são de fundamental importância na concepção do processo de fabricação dos elementos adjacentes à região da ligação, no comportamento global da estrutura e nos serviços complementares realizados no local.

Devido ao seu comportamento próprio as ligações podem promover a redistribuição dos esforços nos elementos e ainda a modificação dos deslocamentos finais da estrutura. As falhas de certas ligações, quando submetidas a determinadas ações, bem como defeitos em sua execução, podem ocasionar deslocamentos excessivos e provocar o colapso da estrutura.

As ligações devem se adequar a critérios relativos à resistência, ductilidade, durabilidade e resistência ao fogo, bem como apresentar aspectos como estética, produção e montagem (EL DEBS - 2000).

Nas ligações entre elementos de concreto pré-moldado, a transferência das tensões de compressão pode ser de duas maneiras: (a) por contato direto; e (b) por inserção de material entre os elementos.

Devido ao comportamento frágil do concreto, o apoio por contato direto é raramente utilizado e limitado a baixas tensões de compressão. O uso de argamassa moldada no local pode ser uma alternativa para minimizar as irregularidades da superfície de contato. Sua gama de utilização é limitada e sua aplicação é restrita a baixos níveis de tensão de compressão, sendo que, esta ainda requer trabalhos adicionais na obra. 
Com relação à inserção de material entre os elementos pré-moldados, o material pode ser rígido ou flexível. O material rígido pode ser feito com elementos metálicos embutidos nas peças pré-moldadas de concreto e, o contato pode ser feito por estes elementos. Este tipo de ligação requer cuidados para garantir a uniformidade dimensional da superfície de contato e freqüente manutenção, porque os elementos metálicos podem ser expostos. Os elementos flexíveis podem ser na forma de almofadas de elastômero. O elastômero mais comum utilizado como elemento de apoio entre elementos de concreto pré-moldado é o policloropreno, conhecido comercialmente como neoprene. Devido a sua flexibilidade este acomoda as irregularidades das superfícies dos elementos pré-moldados, promovendo uma melhor distribuição das tensões, permitindo certas rotações e deslocamentos horizontais entre as peças. Este material apresenta como desvantagem de utilização seu alto custo e necessidade de manutenção periódica.

O que se propõe neste trabalho é o desenvolvimento de um material à base de argamassa de cimento modificada pela introdução de fibras de polipropileno, látex estireno-butadieno (SB) e vermiculita. Este material deve possuir capacidade de deformação de modo que se adeque à utilização como elemento de apoio para os elementos de concreto pré-moldados de concreto. Essa composição foi escolhida devido aos resultados de pesquisas realizadas anteriormente que mostraram que a utilização conjunta desses materiais promove uma redução significativa do módulo de elasticidade do compósito. A escolha da fibra de polipropileno foi motivada devido ao seu baixo custo em relação a outros tipos de fibras encontradas comercialmente para utilização em concretos e argamassas de cimento Portland.

Este material possui a vantagem de ser mais barato que o neoprene comercializado atualmente, mas apresenta a desvantagem de não possuir a amplitude de utilização que o mesmo. Sua utilização fica restrita às ligações onde não se apresentam esforços na direção horizontal da peça, sendo o exemplo mais comum de utilização as ligações vigapilar de estruturas de edifícios comerciais e residenciais e de galpões industriais, como apresentado na Figura 1.1. 


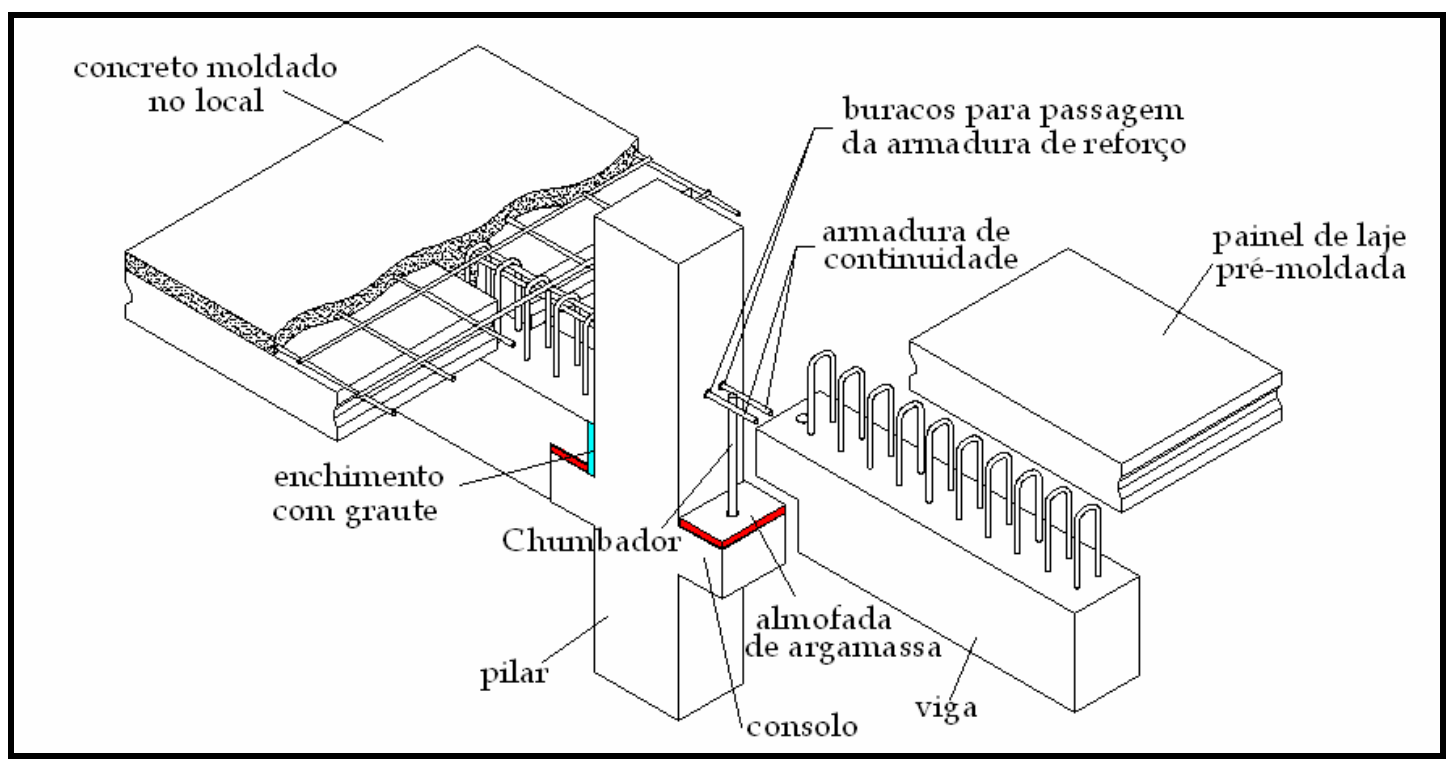

Figura 1.1: Esquema de ligação viga-pilar.

Outra vantagem apresentada pelo material é a capacidade de moldá-lo de acordo com a tipologia da ligação, independentemente do tamanho e do tipo de apoio e da necessidade de vazios na almofada do compósito para adequação aos chumbadores presentes nas ligações. Um exemplo desta moldabilidade do material é apresentada na Figura 1.2.

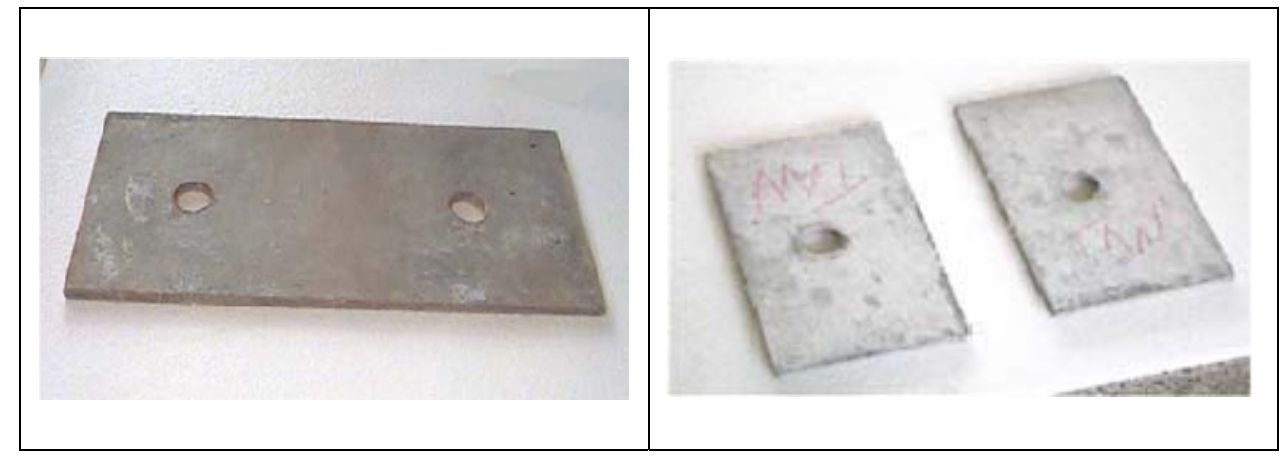

Figura 1.2: Almofadas de apoio de diferentes formatos.

Os estudos com o material vêm sendo desenvolvidos no laboratório de estruturas da Escola de Engenharia de São Carlos desde o ano 2000, com algumas variações dos materiais incorporados na modificação do compósito.

EL DEBS et al. (2003) apresentam resultados de resistência à compressão, tração e módulo de elasticidade para corpos-de-prova cilíndricos de argamassa modificada com 
fibra de polipropileno e PVA, látex SB e vermiculita. São apresentados resultados de almofadas do compósito utilizadas como elemento de apoio em ensaios de ligações do tipo viga-pilar e pilar-pilar, cujos resultados indicaram um grande potencial da utilização do material como elemento de apoio para elementos de concreto prémoldado.

\subsection{Objetivos}

No caso deste trabalho, dando seqüência aos estudos realizados por MONTEDOR (2004), o objetivo principal foi o desenvolvimento de uma almofada feita de argamassa à base de cimento, que seja suficientemente flexível para distribuir as tensões de contato neste tipo de ligação viga-pilar. A utilização de fibras de polipropileno, substituindo as fibras de Vidro e PVA utilizadas anteriormente, tendem a promover uma diminuição do custo final de produção destas almofadas. Por isso o estudo foi dirigido estabelecendose os seguintes objetivos específicos:

a) Avaliar a diminuição do módulo de elasticidade do compósito e rigidez das almofadas do material, conferindo-lhe capacidade de deformação e, promovendo assim, uma conveniente distribuição das tensões na região dos apoios dos elementos pré-moldados;

b) Buscar uma relação entre a quantidade de vermiculita incorporada ao material e seu conseqüente aumento de deformabilidade com diminuição de resistência, buscando-se uma relação de equilíbrio entre estes fatores;

c) Verificar as características resilientes do material, por meio da aplicação de carregamentos cíclicos nas almofadas, mostrando assim, a evolução da rigidez destas nas situações de carregamentos de teor cíclico, a que os elementos estruturais estão submetidos nas situações de utilização das estruturas em geral;

d) Avaliar o emprego da almofada em ligações de blocos de concreto, comparando ligações com a presença do compósito, em relação a elementos íntegros e elementos com emenda feita por junta seca; 
e) Verificar a capacidade de rotação destes elementos para garantir que estes são capazes de absorver este tipo de solicitação sem introduzir esforços adicionais nos elementos da ligação.

\subsection{Justificativas}

As ligações com a utilização de argamassa entre elementos pré-moldados é bastante utilizada devido a sua facilidade de execução. Porém, neste tipo de configuração apresentada, não existem parâmetros suficientes que determinem suas características resistentes, portanto:

$\checkmark$ por se tratar de um material novo, existem poucos estudos neste sentido no país, concentrando-se no Departamento de Engenharia de Estruturas da Escola de Engenharia de São Carlos;

$\checkmark$ O comportamento da argamassa quando utilizada nas ligações ainda é pouco conhecido, necessitando a realização de novos estudos para avaliação mais ampla na sua utlização;

$\checkmark$ A argamassa apresentou boa capacidade de deformação, em alguns testes previamente realizados;

$\checkmark$ A adição conjunta de vermiculita, látex e fibras promove uma redução significativa do módulo de elasticidade do material, sobretudo se comparado à almofada de cloropreno;

$\checkmark$ Já existem vários estudos caracterizando em separado a utilização destes materiais quando incorporados à argamassas de cimento, mas a utilização em conjunto desses três materiais ainda necessita ser estudada pois ainda não foi bem caracterizada a sua capacidade resistente quando utilizada como elemento de apoio.

Com base nos aspectos citados nota-se a relevância do estudo do material, mesmo porque existem variações do tipo de fibras utilizadas que determinam algumas características diferenciadas às argamassas produzidas. 


\subsection{Metodologia}

Para atingir os objetivos deste trabalho foi utilizada a seguinte metodologia:

a) Definição das variáveis do compósito

Em vista do trabalho desenvolvido anteriormente e visando-se economia, foi definida a substituição das fibras de Vidro e PVA por fibra de polipropileno. De posse dos resultados anteriores, foram estipuladas as variações nas quantidades de fibra e vermiculita que seriam incorporadas, limitando-se o estudo a cinco traços diferentes, diminuindo, em muito, a gama de variações a ser estudada.

b) Revisão bibliográfica

Através da revisão bibliográfica foram estudadas as características de modificação que cada um dos elementos introduzidos na argamassa poderiam trazer. Através do comportamento conferido por cada elemento em separado pode-se idealizar o comportamento em conjunto destes elementos e assim criar um compósito voltado ao uso destinado.

\section{c) Ensaios físicos}

Por meio dos ensaios experimentais foram verificadas as características reais do compósito, possibilitando assim, a saída do campo hipotético para o campo das informações reais sobre os corpos-de-prova e almofadas produzidos com este material.

d) Análise dos resultados

Por meio da análise dos resultados, fez-se uma avaliação crítica do compósito em relação às características necessárias para seu uso como elemento de apoio, podendo assim, validar as hipóteses de desempenho do material e influência de sua utilização nas ligações. 


\subsection{Apresentação do Trabalho}

No capítulo 1, introdução, são apresentadas algumas utilizações do compósito bem com algumas discussões das vantagens de sua utilização como elemento de apoio. Tenta-se justificar a relevância da continuidade desse estudo em relação as características que foram alteradas com a introdução de uma fibra diferente da utilizada anteriormente.

No capítulo 2, revisão bibliográfica, são apresentadas as características dos elementos utilizados na modificação da almofada. É apresentada uma pequena revisão bibliográfica sobre os polímeros em geral, bem como as particularidades dos polímeros utilizados nesta pesquisa. Apresenta-se uma pequena revisão das pesquisas realizadas com almofadas desta natureza encontradas na literatura.

No capítulo 3, materiais utilizados, são apresentadas características dos materiais utilizados nesta pesquisa e a caracterização do compósito, os aspectos de dosagem, variáveis que seriam analisadas e propriedades mecânicas verificadas para diferentes traços, que serviriam de parametrização para a realização de todo o programa experimental.

No capítulo 4, programa experimental, são descritos todos os ensaios que foram realizados em almofadas do compósito para verificação das propriedades necessárias a sua utilização.

No capítulo 5, análise dos resultados, foram apresentados todos os resultados obtidos nos vários ensaios que as almofadas de cinco traços do compósito foram submetidas, bem como as comparações dos resultados obtidos na pesquisa realizada anteriormente com o compósito.

No capítulo 6, considerações finais e conclusões, são feitas as considerações finais e conclusões sobre o trabalho, bem como ainda algumas sugestões para trabalhos futuros sobre o material. 



\section{Revisão Bibliográfica}

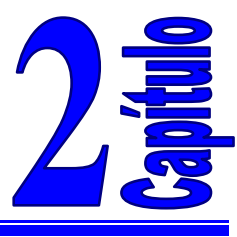

\subsection{Preliminares}

Este capítulo faz uma revisão do que pode ser encontrado na literatura sobre os materiais introduzidos na modificação e utilizados na confecção das almofadas estudadas neste trabalho. Inicialmente trata-se dos polímeros de maneira geral para que se possa entender as características inerentes aos materiais aqui estudados. Em seguida, são mostradas as particularidades de cada material e as principais propriedades que a incorporação de polímeros à argamassa de cimento pode proporcionar. No final é feita uma revisão sobre o que se tem de material específico sobre almofadas de argamassa modificadas por polímeros.

\subsection{Polímeros}

\subsubsection{Considerações Iniciais}

A utilização de polímeros data de muitos séculos atrás, quando se utilizavam as formas que ocorrem naturalmente dos mesmos. Estão inclusos nessas formas naturais dos polímeros: madeira, borracha, algodão, lã, couro e, seda. Nos processos biológicos e fisiológicos são de grande importância outras formas de polímeros naturais como as proteínas, amidos e a celulose. Ferramentas modernas de pesquisa científica tornaram possível a determinação das estruturas moleculares deste grupo de materiais, bem como, o desenvolvimento de numerosos polímeros, os quais são sintetizados a partir de moléculas orgânicas pequenas. De fato, desde o fim da Segunda Guerra Mundial, o campo dos materiais, foi virtualmente revolucionado pelo advento dos polímeros sintéticos. Os materiais sintéticos podem ser produzidos de maneira barata e, as suas propriedades podem ser administradas a um nível em que muitas delas são superiores às 
suas contrapartes naturais (CALLISTER JR., 2000). Alguns dos exemplos de materiais obtidos artificialmente e com grande utilização atualmente são os plásticos, as borrachas e os materiais fibrosos.

Como o próprio nome já diz, as moléculas dos polímeros são compostas de várias partes, e geralmente possuem tamanhos gigantescos, por isso são chamadas de macromoléculas. Essas macromoléculas são compostas por entidades estruturais orgânicas conhecidas por meros, que se repetem sucessivamente, onde os átomos estão ligados entre si através de ligações covalentes. O termo mero tem origem na palavra grega meros, que significa parte. O “mero” representa a unidade que se repete na cadeia de um polímero.

Quando todas as unidades que se repetem ao longo de uma cadeia são do mesmo tipo, o polímero resultante é chamado de homopolímero, e quando a cadeia é composta por duas ou mais unidades mero diferentes, o mesmo é conhecido por copolímero. Estes apresentam melhores combinações de propriedades do que aqueles, sendo que, novos materiais que possam ser fácil e economicamente sintetizados e fabricados vêem sendo continuamente estudados.

A Reação para obtenção de polímeros é denominada polimerização. Geralmente os polímeros apresentam cadeias longas e, consequentemente, elevado peso molecular, sendo que esta característica afeta significativamente as propriedades dos polímeros. Para o caso desta pesquisa, o interesse maior está nos elementos que apresentam elevado peso molecular e, por isso, se apresentam no estado sólido à temperatura ambiente.

As propriedades mecânicas destes elementos são influenciadas por vários fatores, tais como:

$\checkmark$ Peso Molecular: a magnitude do módulo de deformação não parece sofrer influência direta, mas o limite de resistência à tração aumenta com o aumento do peso molecular;

$\checkmark$ Grau de Cristalinidade: tanto o módulo de deformação quanto sua resistência são aumentadas quando se aumenta o grau de cristalinidade (pode-se entender, simplificadamente, a cristalinidade como sendo o 
empacotamento das cadeias moleculares que promovem um arranjo ordenado da estrutura);

$\checkmark$ Temperatura: As propriedades mecânicas dos polímeros são altamente sensíveis à temperatura. Dependendo do uso, é importante o conhecimento das temperaturas de fusão e de transição vítrea. A primeira trata-se da temperatura em que ocorre a transformação de um material sólido em líquido com aquecimento e, a segunda, a temperatura na qual o polímero, que apresenta características de uma borracha, passa para o estado rígido durante o processo de resfriamento. Essas temperaturas são importantes para garantir que as propriedades do uso a que se destina determinado polímero não sofra alterações devido a mudanças no seu estado físico.

A título de exemplo, as variações de características físicas para o polietileno em relação ao seu peso molecular e grau de cristalinidade são mostrados na Figura 2.1. Na Tabela 2.1 são apresentadas as temperaturas de transição vítrea e fusão para alguns polímeros mais comuns.

Tabela 2.1: Temperaturas de Transição Vítrea e de Fusão para alguns tipos de Polímeros (CALLISTER JR., 2000).

\begin{tabular}{lcc}
\hline \multicolumn{1}{c}{ Material } & $\begin{array}{c}\text { Temperatura de } \\
\text { Transição Vítrea } \\
{\left[{ }^{\circ} \mathbf{C}\left({ }^{\circ} \mathbf{F}\right)\right]}\end{array}$ & $\begin{array}{c}\text { Temperatura de } \\
\text { Fusão }\end{array}$ \\
\hline Polietileno (baixa densidade) & $-110(-165)$ & $115(240)$ \\
Politetrafluoroetileno & $-97(-140)$ & $327(620)$ \\
Polietileno (alta densidade) & $-90(-130)$ & $137(279)$ \\
Polipropileno & $-18(0)$ & $175(347)$ \\
Náilon 6.6 & $57(135)$ & $265(510)$ \\
Poliéster (PET) & $69(155)$ & $265(510)$ \\
Cloreto de Polivinila & $87(190)$ & $212(415)$ \\
Poliestireno & $100(212)$ & $240(465)$ \\
Policarbonato & $150(300)$ & $265(510)$ \\
\hline
\end{tabular}




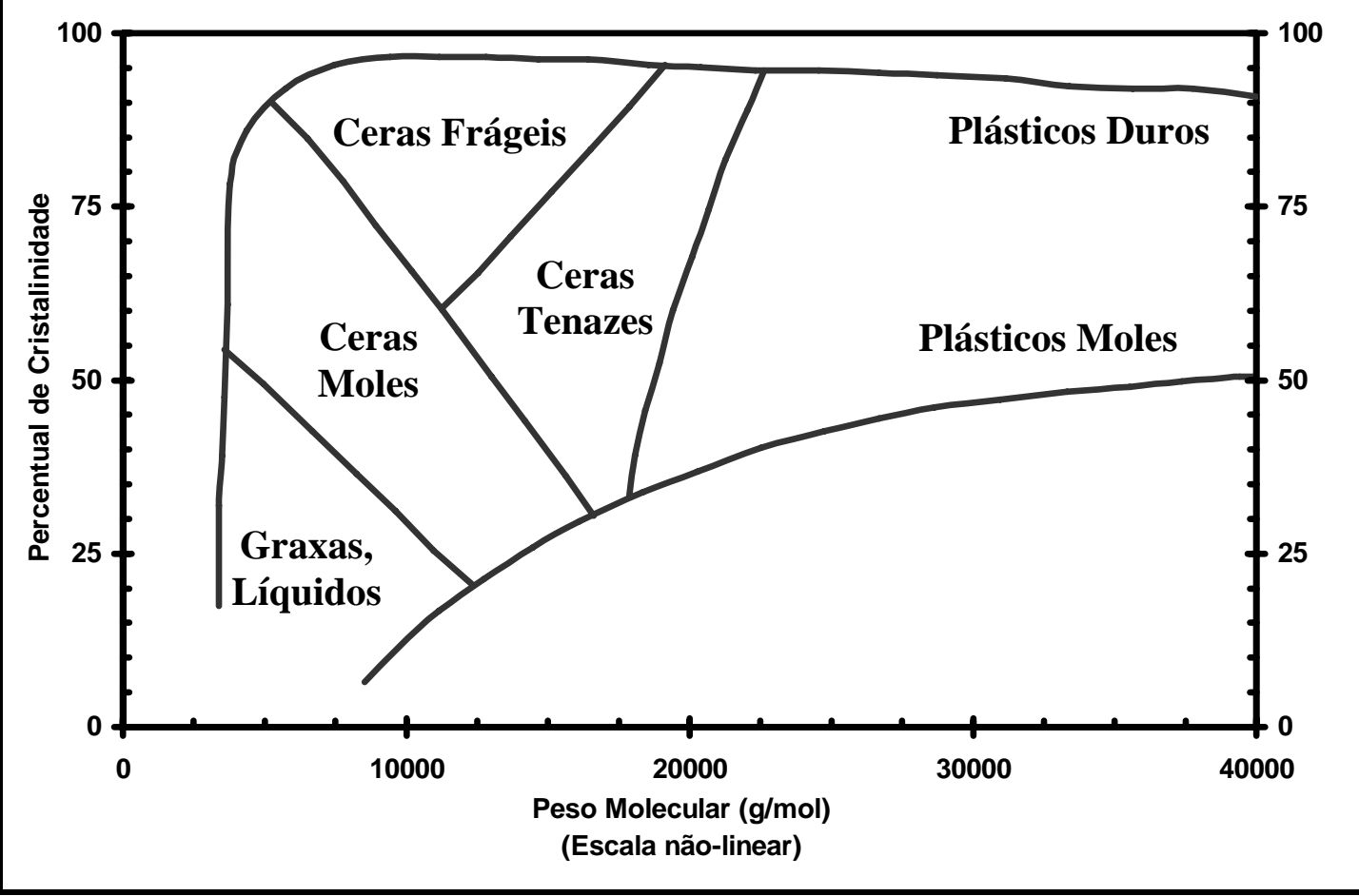

Figura 2.1: Influência do Grau de Cristalinidade e do Peso Molecular sobre as características físicas do Polietileno (CALLISTER JR., 2000).

Os polímeros podem ser classificados, de acordo com a sua resposta mecânica a temperaturas elevadas, em termoplásticos e termofixos. Polímeros termoplásticos amolecem quando são aquecidos (e por fim se liquefazem) e endurecem quando são resfriados, processos que são reversíveis e podem ser repetidos. Os termofixos se tornam permanentemente duros quando aquecidos e não amolecem quando ocorrer uma nova aplicação de calor.

As propriedades dos polímeros (resistência mecânica, resistência a abrasão, tenacidade, estabilidade térmica, rigidez, deteriorabilidade, cor e resistência às chamas) podem ser modificadas e melhoradas com a incorporação de aditivos no seu processo de polimerização.

Existem variados tipos de elementos com uma aplicabilidade extensa e que nos são familiares quando se trata deste tipo de elementos. Dentre eles podemos citar: os plásticos, os elastômeros (ou borrachas), as fibras, os revestimentos, os adesivos, as espumas e as películas. Uma outra variedade de polímeros muito utilizada são os látex, que são polímeros em emulsão em água. Para os objetivos específicos desta pesquisa, os 
polímeros de interesse são os elastômeros, as fibras e os látex e, que terão suas propriedades discutidas a seguir.

Quando o assunto é a aplicação dos polímeros na construção civil o conhecimento da sociedade torna-se parcial, pois embora existam produtos utilizados há um bom tempo como canos de água e esgoto em PVC, telhas plásticas, condutores elétricos e tintas, também há aqueles produtos como revestimentos externos e acústicos, calhas, janelas, polímeros aplicados em estruturas de concreto ou em revestimentos argamassados (produtos mais recentes no mercado), entre outros. Um dos fatores que contribuem para a falta de informação da sociedade em relação à estes produtos é a maior utilização e divulgação dos produtos poliméricos em outros setores como o alimentício, o de eletrodomésticos, o automobilístico e outros, que, comparados aos produtos poliméricos existentes na construção civil, possuem maior tradição no mercado e uma maior escala de produção.

Os avanços tecnológicos alcançados nos últimos anos na tecnologia de processamento dos polímeros devem ser observados, sendo que, o uso dos mesmos tem auxiliado mais a produtividade, a qualidade, o custo, a velocidade e as condições de higiene da obra, se comparado a outros materiais convencionais.

Apesar dos materiais poliméricos serem cada vez mais utilizados na construção, ainda existe um desconhecimento generalizado de sua natureza, características e propriedades (VANDERGORIN, 1987). Um fator importante a ser considerado nessa falta de informação e interesse por parte dos profissionais reside no fato de que, ainda, muitos polímeros oferecem custo mais elevado que outros materiais convencionais, mas se forem consideradas a velocidade de execução, a durabilidade e a baixa manutenção destes materiais, estes tornam-se uma boa opção para serem utilizados.

\subsubsection{Elastômeros}

Uma das propriedades fascinantes dos materiais elastoméricos é a sua elasticidade, que se assemelha à da borracha. Isto é, eles possuem a habilidade de serem deformados segundo níveis de deformação muito grandes e em seguida retornarem elasticamente, tais como molas, às suas formas originais (CALLISTER JR., 2000). Esse 
comportamento foi, provavelmente, primeiro observado na borracha natural, entretanto os últimos anos trouxeram a síntese de um grande número de elastômeros com uma grande variedade de propriedades. Seus módulos de elasticidade são muito pequenos e, além disso, variam em função da deformação, uma vez que a curva tensão deformação para esses materiais não é linear.

Em um estado sem tensões, um elastômero será amorfo e composto por cadeias moleculares altamente torcidas, dobradas e espiraladas. A deformação elástica, mediante a aplicação de uma carga de tração, consiste em desenrolar, destorcer e retificar as cadeias apenas parcialmente e, como resultado, alongá-las na direção da tensão, esse fenômeno está representado na Figura 2.2. Com a liberação da tensão, as cadeias se enrolam novamente de acordo com a sua conformação antes aplicação da tensão e, a peça macroscópica retorna à sua forma original.

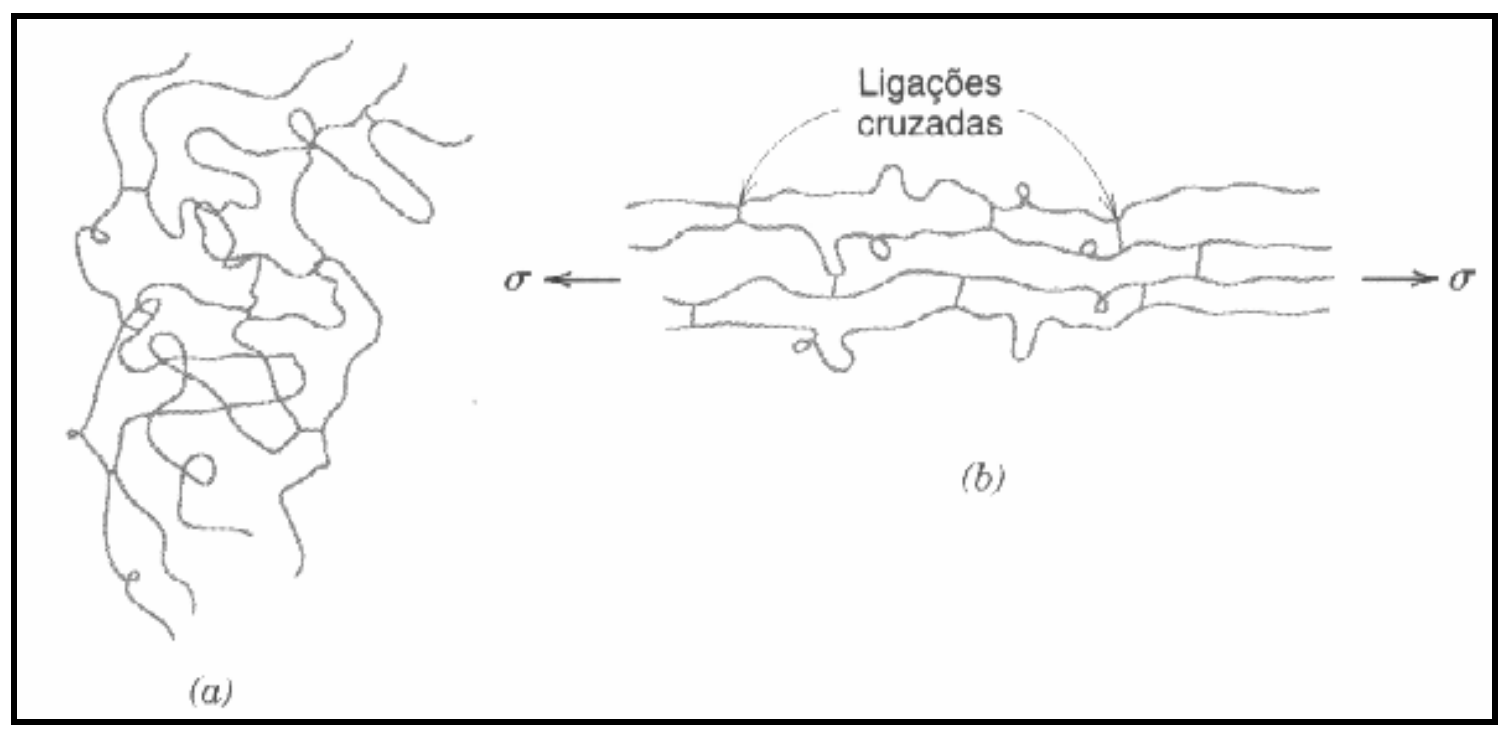

Figura 2.2: Representação esquemática de moléculas de cadeias de polímeros com ligações cruzadas (a) em um estado sem tensão e (b) durante deformação elástica sob aplicação de tensão de tração (CALLISTER JR., 2000).

"Vários critérios devem ser atendidos para que um polímero seja elastomérico:

(1) Ele não deve ser facilmente cristalizável: os materiais elastoméricos são amorfos, possuindo cadeias moleculares naturalmente espiraladas e dobradas em seu estado sem a aplicação de tensões; 
(2) As rotações das ligações da cadeia devem estar relativamente livres, de modo que as cadeias retorcidas possam responder de imediato a aplicação de uma tensão;

(3) Para que os elastômeros experimentem deformações elásticas relativamente grandes, o início do surgimento de uma deformação plástica deve ser retardado. As ligações cruzadas atuam como pontos de ancoragem entre as cadeias e impedem que ocorra deslizamento da cadeia. O papel das ligações cruzadas está mostrado na Figura 2.2b. Em muitos elastômeros, a formação das ligações cruzadas é realizada segundo um processo conhecido por vulcanização;

(4) Finalmente, o elastômero deve estar acima da sua temperatura de transição vítrea, sendo esta a temperatura mais baixa na qual esse comportamento de borracha persiste e, situando-se na faixa entre $-90{ }^{\circ} \mathrm{C}$ e $-50{ }^{\circ} \mathrm{C}$. Abaixo da temperatura de transição vítrea esses elementos se tornam frágeis”.(CALLISTER JR.2000)

O processo de formação das ligações cruzadas nestes elementos é conhecido por vulcanização, como já mencionado anteriormente, o qual é realizado através de uma reação química irreversível, normalmente conduzida a uma temperatura elevada. Na maioria das reações de vulcanização, compostos de enxofre são adicionados ao elastômero aquecido, se ligando as cadeias principais do polímero, que se encontram adjacentes, formando ligações cruzadas entre elas. A reação típica de um processo de vulcanização está mostrada na Figura 2.3, onde m e n consistem em átomos de enxofre.

A borracha não vulcanizada é mole e pegajosa, possuindo baixa resistência à abrasão. Algumas de suas características como, módulo de elasticidade, limite de resistência à tração e a resistência à degradação por oxidação são melhoradas com esse processo de vulcanização. O comportamento comparativo entre os gráficos de tensão-deformação para borrachas naturais vulcanizadas e não vulcanizadas estão mostrados na Figura 2.4. Para que se possa produzir uma borracha capaz de ser submetida a grandes deformações sem que ocorra ruptura das ligações da cadeia primária, devem existir, relativamente, poucas ligações cruzadas e estas devem estar bastante separadas nessa cadeia. Por apresentarem essas ligações cruzadas, os materiais elastoméricos são polímeros termofixos. 


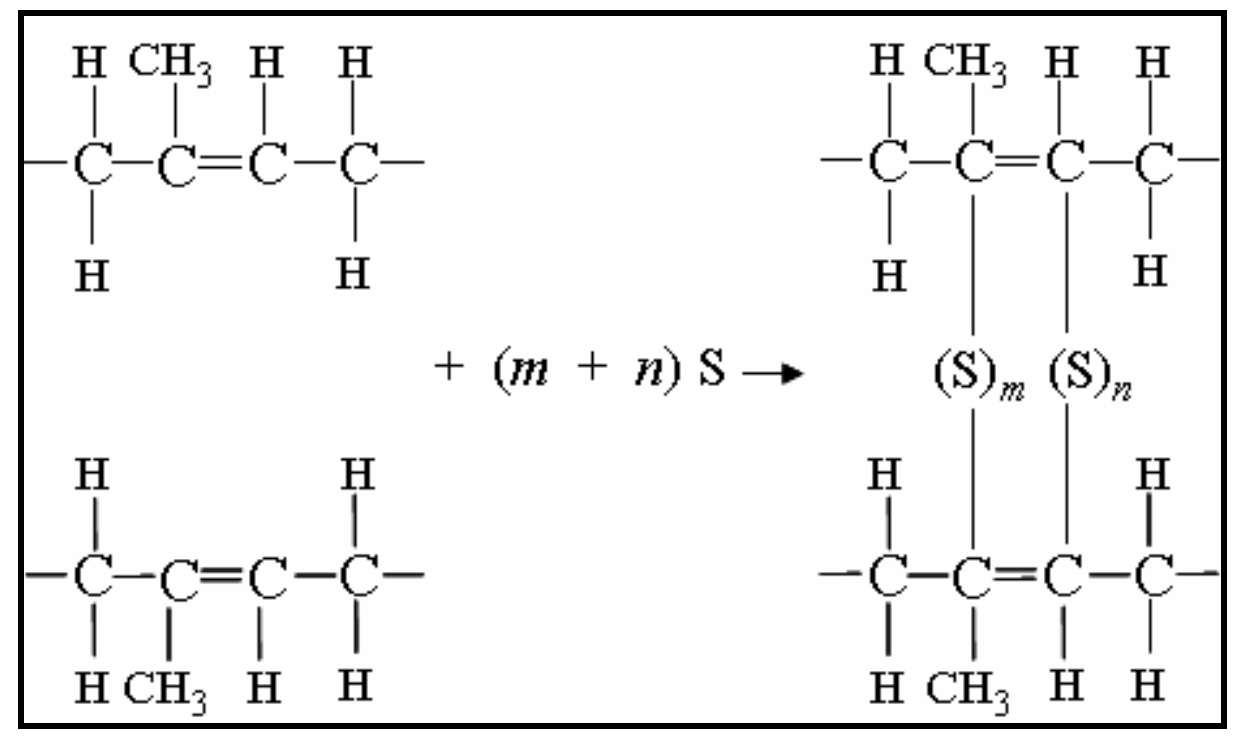

Figura 2.3: Reação de vulcanização de um elastômero (CALLISTER JR., 2000).

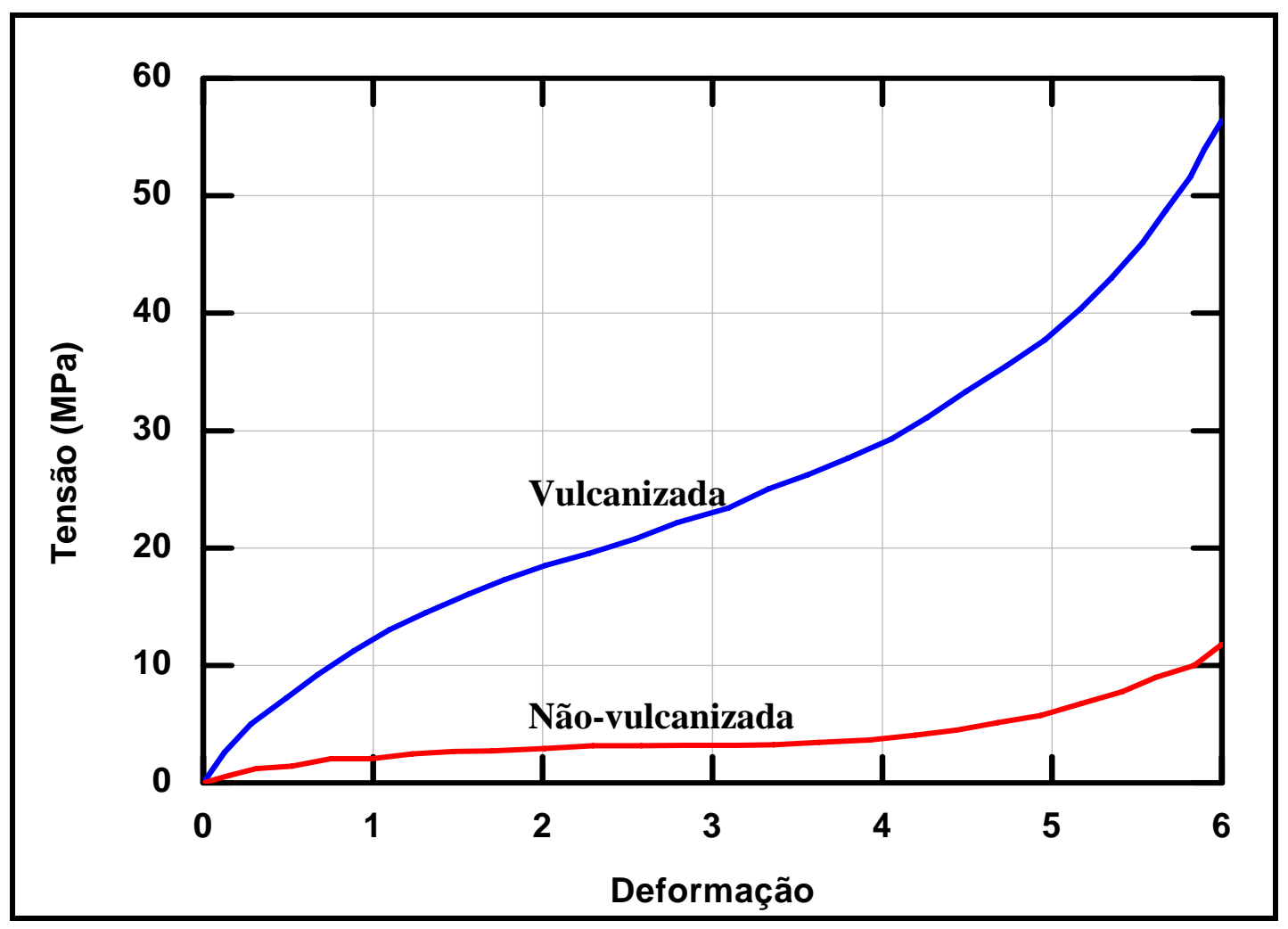

Figura 2.4: Curvas tensão-deformação até um alongamento de $600 \%$ para as borrachas naturais vulcanizada e não-vulcanizada (CALLISTER JR., 2000).

Na Tabela 2.2 são mostradas as propriedades e características importantes de cinco elastômeros mais comuns. Deve-se lembrar que o policloropreno apresentado, é muito utilizado na construção civil como elemento de apoio para elementos de concreto pré- 
moldado. A apresentação de algumas características do policloropreno, também conhecido comercialmente como Neoprene, apesar de não ser o foco principal do trabalho, são de imprescindível conhecimento já que o que se pretende aqui é a criação de um elemento que possa substituir o elastômero em determinadas situações.

Tabela 2.2: Características importantes para cinco elastômeros comerciais (CALLISTER JR., 2000).

\begin{tabular}{|c|c|c|c|c|}
\hline Tipo Químico & $\begin{array}{l}\text { Nome } \\
\text { Comercial } \\
\text { (Comum) }\end{array}$ & $\begin{array}{c}\text { Alongamento } \\
(\%)\end{array}$ & $\begin{array}{c}\text { Faixa Útil de } \\
\text { Temperaturas } \\
{\left[{ }^{\circ} \mathrm{C}\left({ }^{\circ} \mathrm{F}\right)\right]}\end{array}$ & $\begin{array}{c}\text { Principais } \\
\text { Características de } \\
\text { Aplicação }\end{array}$ \\
\hline Poli-isopreno natural & $\begin{array}{l}\text { Borracha Natural } \\
\text { (NR - Natural } \\
\text { Rubber) }\end{array}$ & $500-760$ & $\begin{array}{c}-60 \text { a } 120 \\
(-75 \text { a } 250)\end{array}$ & $\begin{array}{l}\text { Excelentes } \\
\text { propriedades físicas: } \\
\text { boa resistência ao } \\
\text { corte, ao entalhe e à } \\
\text { abrasão; baixa } \\
\text { resistência ao calor, ao } \\
\text { ozônio e ao óleo; boas } \\
\text { propriedades elétricas }\end{array}$ \\
\hline $\begin{array}{l}\text { Copolímero } \\
\text { estireno-butadieno }\end{array}$ & $\begin{array}{l}\text { GRS, } \\
\text { Buna S (SBR) }\end{array}$ & $450-500$ & $\begin{array}{l}-60 \text { a } 120 \\
(-75 \text { a } 250)\end{array}$ & $\begin{array}{l}\text { Boas propriedades } \\
\text { físicas: excelente } \\
\text { resistência à abrasão; } \\
\text { não possui resistência } \\
\text { a óleo, ozônio ou ao } \\
\text { tempo; propriedades } \\
\text { elétricas boas, porém } \\
\text { não excepcionais }\end{array}$ \\
\hline $\begin{array}{l}\text { Copolímero acrilonitrila- } \\
\text { butadieno }\end{array}$ & $\begin{array}{l}\text { Buna A, } \\
\text { Nitrila (NBR) }\end{array}$ & $400-600$ & $\begin{array}{l}-50 \text { a } 105 \\
(-60 \text { a } 300)\end{array}$ & $\begin{array}{l}\text { Excelente resistência a } \\
\text { óleos vegetais, } \\
\text { animais e de petróleo; } \\
\text { propriedades ruins a } \\
\text { baixas temperaturas; } \\
\text { as propriedades } \\
\text { elétricas não são } \\
\text { excepcionais }\end{array}$ \\
\hline Cloropreno & Neopreno (CR) & $100-800$ & $\begin{array}{l}-50 \text { a } 105 \\
(-60 \text { a } 225)\end{array}$ & $\begin{array}{l}\text { Excelente resistência } \\
\text { ao ozônio, ao calor e } \\
\text { às intempéries; boa } \\
\text { resistência ao óleo; } \\
\text { excelente resistência a } \\
\text { chamas; não é tão bom } \\
\text { em aplicações } \\
\text { elétricas como a } \\
\text { borracha natural }\end{array}$ \\
\hline Polissiloxano & Silicone (VMQ) & $100-800$ & $\begin{array}{l}-115 \text { a } 315 \\
(-175 \text { a } 600)\end{array}$ & $\begin{array}{l}\text { Excelente resistência a } \\
\text { temperaturas altas e } \\
\text { baixas; baixa } \\
\text { resistência; excelentes } \\
\text { propriedades elétricas }\end{array}$ \\
\hline
\end{tabular}

\subsubsection{Fibras}

Neste trabalho serão apresentadas as características gerais de alguns tipos de fibras, mas, sendo dada ênfase às fibras poliméricas, em especial à de polipropileno. 
Os polímeros em fibra são capazes de serem estirados na forma de longos filamentos com pelo menos uma relação comprimento-diâmetro de 100:1.

Conforme o AMERICAN CONCRETE INSTITUTE (1993), a relação de aspecto, ou seja, a relação entre o comprimento e o diâmetro equivalente, é um parâmetro que melhor descreve uma fibra, entretanto, TEZUKA (1989) acrescenta que na produção de concretos com fibras, o campo dos diâmetros é bastante extenso, podendo não ser fácil definir uma fibra somente pela relação comprimento/diâmetro.

De acordo com o mesmo autor, existe uma grande variedade de fibras para o uso em matriz de cimento: fibras de silicatos cristalinos como o amianto, de vidro, de metal, o aço carbono e o aço inox, de carbono, de vegetal natural como sisal, cânhamo, juta, coco, etc., de polímero como polipropileno, nylon e polietileno.

Neste trabalho, importante serão as características dos concretos e argamassas de cimento reforçados com fibras (CRF). Estes podem ser definidos como compósitos preparados a partir de cimento hidráulico, agregados de um ou vários tamanhos, que incorpora fibras discretas e descontínuas.

“As fibras mais utilizadas são as de amianto crisotila, de vidro, de aço de alta resistência, de polipropileno e as de coco” (AGOPYAN, 1993). As fibras utilizadas como reforço de matrizes cimentícias podem ser classificadas em dois grupos genéricos:

$\checkmark$ Fibras de baixo Módulo de Deformação, com alto índice de alongamento;

$\checkmark$ Fibras de alto Módulo de Deformação, alta resistência.

Quando incorporadas aos concretos e argamassas, as fibras podem atuar de duas maneiras: no estado fresco e no estado endurecido. No estado fresco elas atuam no controle da fissuração causada pela retração e pela hidratação do cimento e, reduzem a possibilidade de exsudação e segregação do concreto. No estado endurecido, inibem o aparecimento de fissuras por retração plástica e, dependendo da suas características elas podem atuar de maneira a melhorar as características dos elementos quanto ao controle 
da fissuração, resistência à fadiga, resistência ao impacto, resistência ao cisalhamento, tenacidade à flexão.

Fibras com módulo de deformação maior que o da matriz cimentícia, quando incorporadas, atuam no controle da fissuração no estado pré-fissurado, aumentando a resistência do compósito e diminuindo sua ductilidade, pois quando ocorre a deformação da matriz, são transmitidos esforços às fibras que suportam cargas elevadas sofrendo ruptura frágil. Já as fibras com módulo de elasticidade menor que o da matriz cimentícia, não alteram as propriedades do compósito antes da fissuração, aumentando sua tenacidade e ductilidade no estado pós-fissurado, pois atuam como um elemento de costura das fissuras.

De acordo com TEZUKA (1989), as fibras que têm módulo de elasticidade menor e alongamento maior que o da matriz de cimento, geram compósitos com pequeno aumento de resistência, mas, com grande capacidade de absorver energia e, portanto, grande resistência ao impacto e tenacidade. Por outro lado acrescenta, fibras de módulo de elasticidade elevado e grande resistência, tais como as fibras de aço, vidro e carbono, produzem compósitos com características, principalmente, de elevada resistência à tração, rigidez e absorções de ações dinâmicas. Na Tabela 2.3 são apresentadas as propriedades de algumas fibras.

Materiais cimentícios não reforçados com fibra apresentam boa rigidez e adequada resistência a compressão, contudo são frágeis (quebradiços), com baixas capacidades de resistência a tração, a deformação, de resistência ao impacto, a fadiga, além de possuírem baixa tenacidade e ductilidade. Para resolver estes problemas, tem havido um aumento crescente nos últimos 30 anos no uso de concretos e cimentos reforçados com fibras (BENTUR \& MINDESS, 1990; MINDESS \& BANTHIA, 1994; PERUZZI, 2002).

As fibras são introduzidas com o intuito de aumentar a resistência da argamassa ou concreto, embora incrementos modestos possam ocorrer. Seu papel é controlar a fissuração do CRF, e de alterar o comportamento do material uma vez a matriz fissurada, já que atuam como micro-armaduras, ao ligar as fissuras e garantir ao 
material uma pseudoductilidade (BENTUR \& MINDESS, 1990; MEHTA \& MONTEIRO, 1994; SAYEGH, 2001).

Tabela 2.3: Propriedades de algumas fibras - Fonte: TEZUKA (1989).

\begin{tabular}{|c|c|c|c|c|c|c|c|c|}
\hline $\begin{array}{l}\text { Tipo de } \\
\text { Fibra }\end{array}$ & $\begin{array}{c}\text { Diâ- } \\
\text { metro } \\
(\mu \mathrm{m})\end{array}$ & $\begin{array}{c}\text { Massa } \\
\text { Específi- } \\
\text { ca } \\
(\mathrm{Kg} / \mathrm{m} 3)\end{array}$ & $\begin{array}{c}\text { Coeficien- } \\
\text { te de } \\
\text { Poisson }\end{array}$ & $\begin{array}{c}\text { Resistência } \\
\text { à Tração } \\
\text { (MPa) }\end{array}$ & $\begin{array}{c}\text { Módulo de } \\
\text { Elasticida- } \\
\text { de } \\
(\mathrm{GPa})\end{array}$ & $\begin{array}{c}\text { Alonga- } \\
\text { mento } \\
\text { Ruptura } \\
(\%)\end{array}$ & $\begin{array}{c}\text { Teores } \\
\text { Típicos } \\
\text { Volume } \\
(\%)\end{array}$ & $\begin{array}{l}\text { Resistência } \\
\text { aos Álcalis }\end{array}$ \\
\hline $\begin{array}{l}\text { Amianto } \\
\text { (crisotila) }\end{array}$ & $\begin{array}{l}0,02 a \\
20,00\end{array}$ & 2550,0 & 0,3 & 3500,0 & 168,0 & 2,0 a 3,0 & 10,0 & boa \\
\hline Aço & $\begin{array}{l}5,0 a \\
500,0\end{array}$ & 7840,0 & $\begin{array}{c}0,28 a \\
0,33\end{array}$ & 1000 a 3000 & 196 a 210 & 3,0 a 4,0 & 0,5 a 2,0 & boa \\
\hline Vidro E & $\begin{array}{l}9,0 a \\
15,0\end{array}$ & 2550,0 & $\begin{array}{c}0,22 a \\
0,25\end{array}$ & 2100 a 3500 & 77,0 & 2,0 a 3,5 & 1,0 a 8,0 & pobre \\
\hline $\begin{array}{l}\text { Vidro } \\
\text { CEM-FIL }\end{array}$ & $\begin{array}{c}10,0 a \\
20,0\end{array}$ & 2700,0 & 0,2 & 2000 a 2800 & 70 a 84 & 2,0 a 3,0 & 1,0 a 8,0 & razoável \\
\hline Carbono & 8,0 & 1900,0 & 0,2 a 0,4 & 2450 a 3150 & 230 a 315 & 1,0 & $\begin{array}{l}2,0 a \\
12,0\end{array}$ & boa \\
\hline $\begin{array}{l}\text { Kevlar } \\
\text { PRD } 49\left(^{*}\right)\end{array}$ & 10,0 & 1450,0 & 0,3 & 2900,0 & 130 a 140 & 2,0 & $<2,0$ & boa \\
\hline $\begin{array}{l}\text { Polipropile- } \\
\text { no Fibrilado }\end{array}$ & $\begin{array}{c}4,0 a \\
30,0\end{array}$ & 910,0 & $\begin{array}{c}0,29 a \\
0,46\end{array}$ & 300 a 400 & 6,0 a 8,0 & 8,0 & $\begin{array}{c}0,2 a \\
2,0\end{array}$ & boa \\
\hline Coco & $\begin{array}{c}100,0 \\
a \\
400,0\end{array}$ & - & - & 120 a 200 & 19 a 26 & 10,0 a25,0 & 1,0 a 5,0 & pobre \\
\hline Sisal & $\begin{array}{l}7,0 a \\
47,0\end{array}$ & - & - & 280 a 568 & 13 a 26 & 3,0 a 5,0 & 1,0 a 5,0 & pobre \\
\hline Juta & $\begin{array}{l}20,0 a \\
100,0\end{array}$ & - & - & 250 a 350 & 26 a 32 & 1,5 a 2,0 & 1,0 a 5,0 & pobre \\
\hline
\end{tabular}

(*) Kevlar - poliamida aromática da Du Pont.

O reforço de argamassas e concretos de cimento Portland com fibras é uma maneira bastante eficiente de reduzir a fragilidade na ruptura destes materiais, aumentar a durabilidade e conferir propriedades mecânicas não encontradas nas argamassas e concretos convencionais, relacionada à capacidade de deformação e absorção de energia.

Segundo SWAMY (1992), de maior importância prática, é a ação das fibras como pontes entre as fissuras e a melhora da capacidade de deformação na flexão pela matriz. Do mesmo modo, de suma importância temos, a habilidade das fibras em inibir aumento de fissuras instáveis e transformar uma ruptura frágil e rápida em ruptura estável e lenta, 
com tolerância ao dano, ductilidade na pós-fissuração e grande capacidade de absorção de energia antes da ruptura.

As propriedades mecânicas dos materiais reforçados com fibras podem ser explicadas a partir das características de sua microestrutura. "Destaca-se que pelo estudo da microestrutura, obtém-se a resposta para a influência do tipo de fibra, idade de hidratação e relação água/cimento e de como esses fatores devem ser devidamente definidos a fim de que haja uma dosagem racional do compósito a ser empregado na prática” (MEHTA \& MONTEIRO,1994).

Quando se trata de ensaios com materiais fibrosos, destaca-se que durante o carregamento do material, a tensão na qual ocorre a primeira fissura da matriz costuma aumentar com a aderência e, ainda, com a relação comprimento-diâmetro e concentração de fibras. Ao se elevar a aderência, obtém-se um acréscimo da resistência à tração na fase elástica de solicitação e, em alguns casos, a redução da ductilidade. Assim sendo, os ensaios a serem empregados devem auxiliar a escolha da situação ótima, na qual se compatibilizam tenacidades elevadas e resistências aceitáveis.

As características das fibras não são as únicas responsáveis pelo melhor desempenho dos compósitos. Acréscimos na resistência à tração, deformação específica e ductilidade podem ser obtidos através do proporcionamento adequado de agregados (como a utilização de vermiculita, por exemplo), da relação água/cimento e de outras adições.

A maior aderência fibra-matriz, por sua vez, pode ser obtida a partir de reduções da porosidade e da concentração de portlandita (hidróxido de cálcio). Além disso, a utilização de fibras de perfil irregular confere acréscimos de até 10\% para a resistência à tração do compósito, ao ser comparada à resistência obtida com fibras cilíndricas e lisas (BENTUR; MINDESS; DIAMOND, 1985c).

De acordo com BARTOS (1992), podem ser citadas as seguintes características que podem ser alteradas melhorando a performance do material:

- Resistência - inclusas: à tração, compressão, cisallhamento, flexão, impacto, fadiga, grau de isotropia; 
- Tenacidade - incluídos: último deslocamento, modo de ruptura, energia de fraturamento, grau de isotropia;

- Deformação e estabilidade dimensional - compreendidos: módulo de deformação, retração/inchamento, deformação elástica/plástica, movimento térmico;

- Densidade, permeabilidade aos gases e líquidos, transmissão e retenção de calor, transmissão sonora, propriedades elétricas;

- Aparência de superfície - inclusa a habilidade de aceitar diferentes tipos de tratamentos e acabamentos superficiais;

- Durabilidade - definida como a quantidade de tempo durante o qual são mantidos parâmetros de performance requeridos.

Segundo BALAGURU \& SHAH (1992) os principais parâmetros que afetam a interação fibra-matriz são:

$\checkmark$ Condição da matriz (fissurada ou não);

$\checkmark$ Composição da matriz;

$\checkmark$ Geometria da fibra;

$\checkmark$ Tipo de fibra (metálica, polimérica, vidro etc);

$\checkmark$ Características da superfície da fibra;

$\checkmark$ Rigidez da fibra em comparação com a da matriz;

$\checkmark$ Orientação das fibras (alinhadas ou distribuídas aleatoriamente);

$\checkmark$ Quantidade de fibras adicionadas;

$\checkmark$ Velocidade de carregamento;

$\checkmark$ Durabilidade das fibras no compósito.

A principal contribuição da adição de fibras nos concretos e argamassas de cimento Portland é no estado de pós-fissuração, em que podem desempenhar duas funções: aumentar a resistência do compósito, transferindo tensões através de fissuras; e aumentar a tenacidade por fornecer mecanismos de maior absorção de energia, pelo alongamento e deslocamento das fibras. Em se trabalhando tridimensionalmente, na matriz de cimento Portland detêm-se as microfissuras a partir do início de sua formação. A fissuração plástica é provocada pelo assentamento e/ou pela retração devido à rápida evaporação da água de amassamento. As fibras atuam interceptando as microfissuras, 
absorvendo e dispersando a energia que, uma vez sem controle, produz um quadro patológico de fissuras próprias de todas as massas que contenham o cimento Portland. $\mathrm{O}$ importante advento da interceptação das microfissuras, em seu estágio inicial, é obtido pela disseminação de milhares de fibras, interconectadas, que formam uma armadura em forma de rede tridimensional.

Quando se trata da incorporação de fibras a pasta de cimento, existem várias referências citando a relação entre uma quantidade ideal de fibra com o ganho de resistência. Se a incorporação for menor que essa quantidade, o ganho de resistência não é significativo, se maior que essa quantidade, aumenta-se em muito a incorporação de ar por parte da argamassa, promovendo uma diminuição da resistência da argamassa. Nesta pesquisa, como o ganho de resistência em grande escala não é o fator preponderante, não há uma preocupação muito grande com a quantidade de fibra a ser incorporada, sendo a preocupação principal a resposta final do compósito a essa incorporação e a atuação conjunta de todos os elementos incorporados.

\subsubsection{Látex}

O termo látex foi originalmente empregado para designar o produto natural obtido da seringueira, um leite branco constituído por partículas de borracha sólida dispersas em água. Atualmente, qualquer material polimérico em emulsão na água é chamado de látex, sendo que, o mesmo é composto por cerca de 50\% de polímero em massa e 50\% de água (TEZUKA, 1988).

Segundo WALTERS (1988), látex são dispersões de partículas de polímeros orgânicos em água. São fluídos leitosos que apresentam coloração branca. Sua consistência pode variar de fluido a muito viscoso.

A definição de látex pode ser complementada pelos pesquisadores MEHTA \& MONTEIRO, 1994, que designam o látex como uma suspensão coloidal do polímero em água, contendo cerca de 50\% em peso de partículas esféricas muito pequenas de polímero, mantidas em suspensão na água por agentes tenso-ativos.

A primeira referência aos látex ocorreu no início do século XVI, quando exploradores espanhóis relataram que índios da América do Sul fabricavam sapatos a partir de látex 
retirados de árvores. O tipo de árvore, conhecida como hevea brasiliensis, produz o material conhecido como látex de borracha natural (NRL - Natural Rubber Latex) (WALTERS, 1987).

A utilização de materiais poliméricos para modificação de concretos e argamassas vem sendo bastante difundida nos últimos anos, sendo estes elementos conhecidos, genericamente, por concretos poliméricos.

Segundo CHODOUNSKY \& BINA (1997), o desenvolvimento das propriedades do concreto endurecido pela adição de polímeros está entrando na sua quinta década. Nas décadas de 40 e 50, tanto o concreto de polímero como o concreto modificado com polímero já eram utilizados.

Cabe aqui neste momento promover uma classificação dos tipos de produtos que podem ser desenvolvidos a partir da modificação das argamassas e dos concretos com os polímeros. Estes são classificados da seguinte maneira:

\section{(a) Argamassa e Concreto de Polímero (CP)}

Esse tipo de argamassa e/ou concreto, não possui cimento Portland como aglomerante, a matriz principal é uma resina polimerizável acrescida de outro material sob a forma de agregado ou filler.

O concreto e as argamassas de polímero são todos os materiais constituídos de uma matriz de polímero e filler, preparado através da mistura completa da matriz polimerizável (monômero ou resina) e agregados, seguida de polimerização in situ (AMERICAN CONCRETE INSTITUTE, 1993).

“As características de um concreto de polímero específico são dependentes das características de cada componente (agregado miúdo, agregado graúdo, filler e tipod e polímero) e suas quantidades relativas[...]. O concreto de resina pode desenvolver resistência à compressão da ordem de 140MPa em horas ou até mesmo em minutos, sendo, adequado para concretagens de emergência em minas, túneis e auto-estradas, recuperações de edifícios, etc.”(CHODOUNSKY \& BINA, 1997). 


\section{(b) Argamassa e Concreto Impregnado de Polímeros (CIP)}

Os concretos e as argamassas impregnadas de polímeros são obtidos através da aplicação de uma solução saturada de um monômero em um elemento previamente seco, com subseqüente polimerização, ou com a utilização de pressão para que o processo de impregnação seja efetivo. Essa impregnação é alcançada com o auxílio de radiação ou catalisadores térmicos.

De acordo com o AMERICAN CONCRETE INSTITUTE (1993), os concretos e argamassas de cimento Portland são impregnados com um monômero e posteriormente polimerizados. De forma geral, quase todos os tipos de material endurecido, de diferentes tamanhos e configurações podem ser impregnados com um monômero em um certo grau.

Segundo CHODOUNSKY \& BINA (1997), no concreto endurecido, os vazios (contendo água e ar), compreendendo poros capilares e microfissuras, não se apresentam totalmente interligados, isto dificulta a penetração do polímero se sua viscosidade é alta, portanto, no processo de produção do CIP, é essencial não somente selecionar um polímero de baixa viscosidade, mas também, secar e criar vácuo no concreto antes da impregnação. Monômeros como o metil-metacrilato e estireno são comumente utilizados devido às suas propriedades adequadas e consequentemente têm conduzido a concretos de melhores propriedades.

Os concretos e argamassas impregnados de polímero apresentam melhorias de desempenho, se comparados aos concretos e argamassas convencionais de cimento Portland, nas seguintes propriedades: resistência à compressão, resistência ao impacto, resistência à tração, resistência à abrasão, resistência ao ataque de agentes agressivos, resistência ao gelo e degelo, permeabilidade, módulo de elasticidade, deformação lenta e retração por secagem (SILVA, 1996).

CHODOUNSKY \& BINA (1997) mostram que em geral, a resistência à tração e compressão destes concretos impregnados de polímero é quatro vezes maior que a do concreto convencional, porém o alto custo desta prática só se justifica em casos onde não é possível a aplicação de outros materiais.

\section{(c) Argamassa e Concreto Modificado com Látex (CML)}

Os concretos e argamassas modificados com látex podem ser entendidos como uma categoria especial dos concretos modificados com polímeros (CMP), pois 
utiliza-se o látex como elemento modificador, sendo que este é constituído de uma quantidade em sólidos de polímero em emulsão.

O concreto modificado com polímero (CMP), no que se refere aos materiais, diverge do concreto de cimento Portland convencional apenas pela adição de um monômero ou polímero, disperso em solução aquosa, proporcionando uma polimerização in situ (GOMES, 2000).

As argamassas e concretos polímeros modificados são obtidos, quando no processo de mistura, com o material fresco, são adicionados polímeros ou monômeros, sendo realizada a cura e polimerização. Dentre as formas de utilização de polímeros em concretos e argamassas, esta apresenta grande vantagem, pois não necessita de mudanças significativas na tecnologia e processo de produção e nem a utilização de equipamentos especiais (ROSSIGNOLO, 1999).

Segundo OHAMA (1987), a modificação dos concretos e argamassas é conseqüência da hidratação do cimento Portland e da coalescência das partículas de polímero formando filmes contínuos ou membranas, que ligam-se aos géis hidratados do cimento e aos agregados, construindo uma cadeia monolítica na qual a fase polímero interpenetra completamente a fase do cimento Portland hidratado. Esta fase polimérica do material é a responsável pela diminuição da permeabilidade do material e pelo aumento da aderência entre a pasta e o agregado.

“Há muitos tipos de látex no mercado, mas aproximadamente 5\% deles podem ser utilizados convenientemente com aglomerantes hidráulicos. Os outros 95\% poderão coagular quando combinados com cimento” (AMERICAN CONCRETE INSTITUTE, 1995).

Entre os tipos de látex que podem ser utilizados como aglomerantes hidráulicos podem ser citados como os mais utilizados atualmente: estireno-butadieno e policloropropeno (sintéticos); e éster poliacrílico, estireno acrílico, acetato de vinila e acetato de polivinila (termoplásticos) (BALLISTA, 2003).

Os látices utilizados com aglomerantes hidráulicos são geralmente produzidos por um processo conhecido como polimerização de emulsão, cujo processo básico envolve a mistura do monômero com água, surfactantes (estabilizadores) e catalizadores.

O maior efeito dos surfactantes reflete-se na trabalhabilidade da mistura, aumentando-a consideravelmente, sendo colaborante na redução da relação água/cimento (a/c) em concretos e argamassas modificados com látex. 
O teor de ar incorporado por argamassas e concretos de cimento Portland modificados com látex é aumentado de forma considerável pela ação dos estabilizadores do látex, no entanto, apesar da incorporação de ar diminuir a resistência à compressão, ela promove uma melhora considerável na absorção de deformações.

A melhoria nas propriedades de argamassas e concretos de cimento Portland é obtida pela diminuição na quantidade e redução no diâmetro de poros capilares e aumento das forças de ligação entre o agregado e a matriz hidratada de cimento.

De acordo com o AMERICAN CONCRETE INSTITUTE (1995), a modificação com látex ajuda de duas formas: as partículas do látex não somente reduzem a quantidade da movimentação de água através do bloqueio dos capilares, mas, também quando há fissuração, o filme de látex polimérico tampa estes canais e restringe sua propagação.

Por meio de análise microestrutural de argamassas e concretos modificados com polímero, pode-se observar a formação de pontes de polímeros através de microfissuras, restringindo a propagação destas. Nota-se também uma forte ligação entre a matriz aglomerante e os agregados. Estes são os principais motivos pelos quais os concretos e argamassas modificados adquirem uma maior resistência à tração (ROSSIGNOLO, 1999).

Ainda segundo o AMERICAN CONCRETE INSTITUTE (1995), o ponto ótimo de modificação com polímero situa-se entre 5\% e 10\% do teor de sólidos por peso de cimento. Percentagens menores não propiciam mudanças significativas nas propriedades dos concretos e argamassas modificados. Além disso, não trarão os benefícios da redução significativa da quantidade de água de amassamento, visto que os látex possuem propriedades plastificantes no concreto fresco. O uso de sólidos em excesso torna-se inviável economicamente e pode causar elevada incorporação de ar ou um comportamento de polímero preenchido de agregados e cimento, no qual o cimento entra como filler, ocorrendo descaracterização do processo de modificação.

A formação da matriz aglomerante dos concretos modificados com látex se caracteriza pela hidratação do cimento e pela coalescência das partículas de polímeros presentes no látex, formando um filme de polímero. Dessa forma, a matriz aglomerante é constituída de duas fases, a matriz de cimento hidratado e o filme polimérico, que preenche parcialmente os vazios da matriz de cimento. Nesse 
processo, a hidratação do cimento precede o processo de coalescência do polímero (OHAMA, 1998) e (ROSSIGNOLO, 2003).

A modificação das argamassas e dos concretos de cimento Portland com polímeros é determinada tanto pela hidratação do cimento como pelo processo de formação do filme de polímero em sua fase de deposição. A hidratação do cimento, em geral, precede o processo de formação do filme de polímero, pela coalescência das partículas de polímero. Em ambos os casos, a fase co-matriz é formada na hidratação do cimento e no processo de formação do filme de polímero.

A fase co-matriz é geralmente formada de acordo com o modelo simplificado mostrado na Figura 2.5. Na Figura 2.6 está sendo ilustrado o modelo idealizado do processo de formação do filme de polímero na partícula de cimento hidratado.

De acordo com OHAMA (1998) as microfissuras na argamassa ou concreto modificados sob tensão são ligadas através dos filmes de polímero ou membranas formadas, o que previne a propagação de fissuras e, simultaneamente, desenvolve uma forte ligação entre o cimento hidratado e o agregado. Dessa forma, as propriedades das argamassas ou concretos de cimento Portland são geralmente melhoradas em grande escala pela modificação com o látex.

As etapas que ocorrem durante o processo de formação do filme polimérico na mistura e que foram retratadas por OHAMA (1987) são as seguintes:

Primeira Etapa:

“Quando o polímero látex é misturado com o concreto ou argamassa de cimento Portland, ainda fresco, as partículas do látex estão dispersas uniformemente na pasta de cimento. Nesta pasta de cimento e polímero, o gel de cimento é gradualmente formado pela hidratação do cimento, e a fase líquida é saturada com hidróxido de cálcio formado durante o processo de hidratação, enquanto as partículas do polímero látex depositam-se parcialmente na superfície do gel já formado e dos grãos ainda não hidratados de cimento. É provável que ocorra a formação de uma camada de silicato de cálcio em função da reação do hidróxido de cálcio na fase líquida com a sílica da superfície dos agregados”. 
(a) inediatamente apos a mistura

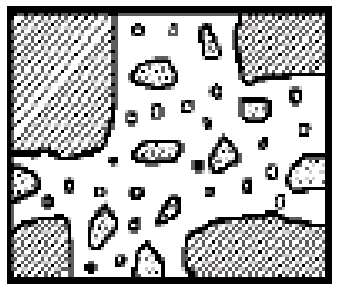

S particulas de cimento nảo hidratadą

- particulas de polímero

agregados

[a f́gua ucupa as espaços

iatersticiais;

(b) primeira passa

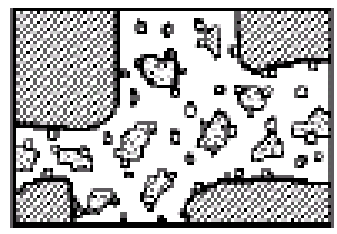

mistara de particulas năo hidratadas de cimento, gel de cimento

(nesta fase, ecorre uma deposiças parcial das particulas de polimero)

(c) segundo passo

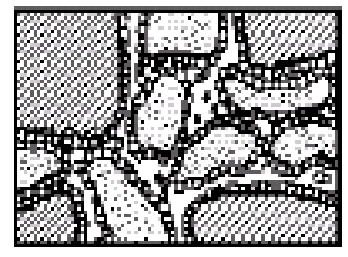

mistura de gel de cinnento e partnä́n hidratadas de cimento envelapadas com una camada de partieulas de polimero

(d) terceiro passo

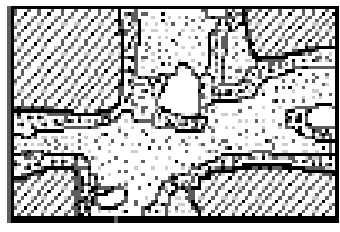

particula de cimento hidratado envolvida com filme de polimero

ax aprisionado

Figura 2.5: Modelo idealizado de formação do concreto de cimento polímero (OHAMA, 1998 apud. PERUZZI, 2002).

Segunda Etapa:

“Com a formação da estrutura do gel de cimento Portland, as partículas de polímero são gradualmente confinadas nos poros capilares. O desenvolvimento da hidratação do cimento reduz a água capilar, as partículas do polímero floculam formando uma camada contínua e compacta de polímero sobre a superfície do gel de cimento e também de seus grãos não hidratados, aderindo simultaneamente a estes e a camada de silicato de cálcio formada sobre a superfície dos agregados. Neste caso, os poros maiores presentes na mistura são colmatados pelas partículas do polímero”. 


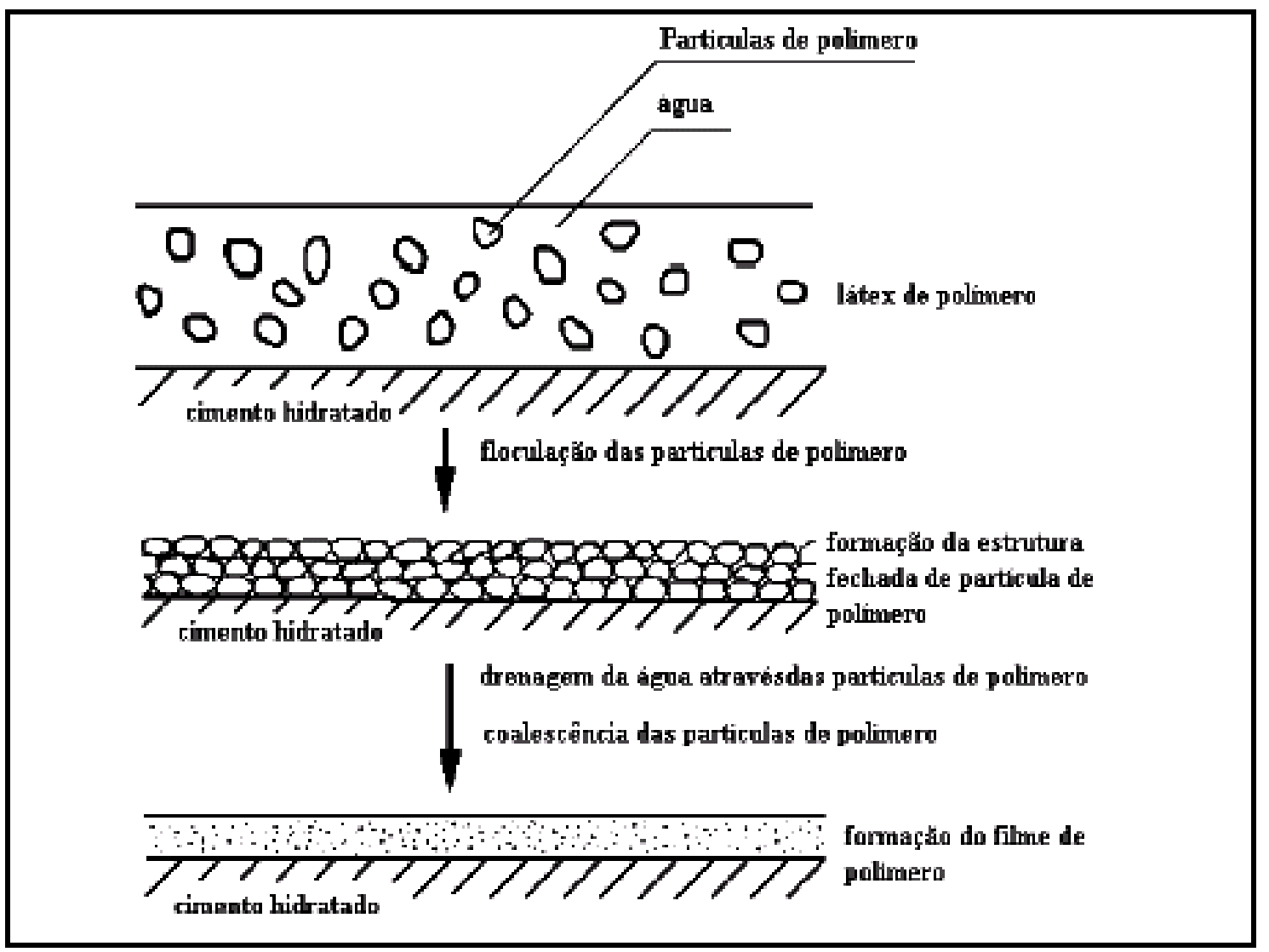

Figura 2.6: Modelo idealizado do processo de formação do filme de polímero na partícula de cimento (STORTE, 1991 apud. PERUZZI, 2002)

Terceira Etapa:

“Finalmente, com a redução da água combinada da hidratação do cimento, as partículas do polímero coalescem sobre o cimento hidratado, formando filmes contínuos ou membranas, que ligam-se aos géis hidratados do cimento e agregados, construindo uma cadeia monolítica na qual a fase polímero interpenetra completamente a fase do cimento Portland hidratado”.

De acordo com STORTE (1991), essa combinação das partículas do polímero com os silicatos de cálcio é irreversível, o que comprova que existe aderência química das partículas de látex com o cimento Portland hidratado. 


\subsection{Argamassas modificadas com látex estireno-butadieno}

Várias são as propriedades que podem ser observadas na modificação das argamassas com o látex SB, mas para os objetivos específicos desta pesquisa serão apresentadas apenas as propriedades que serão de interesse direto ao uso dos elementos produzidos.

\subsubsection{Consistência/Trabalhabilidade}

As argamassas e concretos modificados com o látex SB apresentam um aumento na trabalhabilidade com relação às argamassa e concretos não modificados. Isto se deve ao dispersante dos componentes do látex combinados a água. As partículas do polímero agem como plastificantes, aumentando consideravelmente a trabalhabilidade das misturas para uma mesma relação água/cimento, promovendo assim, os benefícios dos plastificantes.

\subsubsection{Teor de Ar Incorporado}

O teor de ar incorporado altera as propriedades de resistência mecânica dos concretos e argamassa, diminuindo-as com o seu aumento, portanto, deve ser controlado. Por isso, são adicionados aos látex agentes anti-espumantes. “Os látex já estão sendo comercializados com estes agentes e, como conseqüência, o teor de ar incorporado nos concretos de cimento e polímero é da ordem de $2 \%$, quase a mesma proporção de um concreto convencional”(STORTE, 1991).

\subsubsection{Tempo de Pega}

Quanto à esta propriedade, tem-se observado que a modificação com látex não altera significativamente a mesma, podendo-se obter valores levemente maiores do que os apresentados pelos concretos convencionais.

De acordo com o AMERICAN CONCRETE INSTITUTE (1995), existe uma restrição quanto ao tempo de aplicação dessas argamassas modificadas, que não se relaciona com o tempo de pega, mas está relacionada à secagem da superfície, quando o látex começa a formar filmes (coalescer), o que ocorre em poucos minutos. Se a 
superfície de uma mistura com látex torna-se muito seca, ocorre a formação de uma membrana ou pele (coalescência do polímero). Geralmente, o tempo disponível para se trabalhar com o material é de quinze a trinta minutos após mistura e exposição ao ambiente.

\subsubsection{Resistência à Compressão}

Praticamente não costumam ocorrer alterações significativas na resistência à compressão dos concretos e argamassas modificados com o látex estireno-butadieno. Na verdade ganhos significativos podem ocorrer por causa da redução da água de amassamento, em virtude das propriedades plastificantes dos látex.

STORTE (1991), entretanto, destaca que a resistência à compressão é bastante influenciada pelo teor de sólidos e tipo de látex utilizado, assim como pela quantidade de monômeros que formam o polímero.

Os ganhos significativos de resistência à compressão apresentados pelos materiais modificados com o látex SB se devem basicamente a essa redução do fator água/cimento da mistura. Nas pesquisas realizadas houve um ganho de resistência à compressão por parte das argamassas e concretos modificados que foram atribuídos à essa diminuição da quantidade de água de amassamento, não foi encontrada nenhuma pesquisa que tratasse especificamente das propriedades do látex melhorando as características à compressão das argamassas e concretos modificados.

\subsubsection{Resistência à Tração}

AFRIDI (1995), afirma que os concretos modificados com látex estirenobutadieno têm sua resistência mecânica melhorada sobremaneira, sobretudo no que se refere à tração. O autor obteve, em suas pesquisas, ganhos de até 100\% nessas características. O mesmo é observado por KUHLMANN (1987), que afirma que as modificações promovidas pela adição do látex geram concretos com maior resistência à flexão e tração.

FOLIC \& RADONJANIN (1998) obtiveram ganhos de $40 \%$ no valor da resistência à tração na flexão em relação ao concreto de referência, para uma adição de 7,5\% do teor de sólidos/cimento de estireno-butadieno. Estes autores destacam que a 
resistência à tração depende fundamentalmente da aderência entre os agregados e a matriz de cimento, e a adição do polímero pode ajudar das seguintes formas:

1. Aumentando esta aderência;

2. Protelando a microfissuração inicial devido ao menor módulo de elasticidade.

\subsubsection{Módulo de Elasticidade}

As modificações promovidas pela adição de látex, geralmente, nos remetem a concretos com menor módulo de elasticidade.

STORTE (1991) obteve módulo de elasticidade estático com 90\% do módulo do concreto de referência para traços com $\mathrm{D}_{\text {máx }}=9,5 \mathrm{~mm}$, relação teor de sólidos/cimento = $5 \%$ e consumo de cimento de $320 \mathrm{~kg} / \mathrm{m}^{3}$, e $80 \%$ do módulo do concreto de referência para traços com $D_{\text {máx }}=9,5 \mathrm{~mm}$, relação teor de sólidos/cimento $=10 \%$ e consumo de cimento de $320 \mathrm{~kg} / \mathrm{m}^{3}$.

\subsubsection{Retração por Secagem}

“A retração não aumenta com o acréscimo de látex. Entretanto, as argamassas e concretos modificados com látex são mais susceptíveis à retração inicial quando não submetidos a processos eficazes de cura” (AMERICAN CONCRETE INSTITUTE, 1995).

OHAMA (1998) demonstrou que a adição de látex ao concreto não aumenta o valor de sua retração final. Em sua pesquisa, o autor utilizou três porcentagens de látex estireno-butadieno em corpos-de-prova de concreto de três diferentes tamanhos. O abatimento foi mantido constante através do ajuste do fator a/c. A medida da retração após vários dias de cura demonstrou que a retração é governada pela quantidade de água e não aumenta com a adição de látex.

\subsubsection{Permeabilidade/Absorção}

“A estrutura dos concretos modificados com látex é tal que os microporos e vazios encontrados no concreto convencional estão parcialmente preenchidos com o filme de polímero que se forma durante o período de cura. Este filme é responsável pela 
redução da permeabilidade e absorção de água. Esta propriedade tem sido exaustivamente estudada em vários tipos de ensaios, tais como absorção de água, resistência a carbonatação e permeabilidade a cloretos” (AMERICAN CONCRETE IINSTITUTE, 1995).

Segundo OHAMA (1991) e RAY et al. (1995), a diminuição da permeabilidade dos concretos de cimento Portland modificados com látex de estireno-butadieno ocorre pela diminuição dos vazios do material, ocasionado pela formação da membrana de polímero e pela diminuição da quantidade e do diâmetro dos poros capilares.

As pesquisas realizadas por KUHLMANN (1987), apontam que a adição de látex estireno-butadieno reduz de maneira significativa as características de permeabilidade em comparação a concretos convencionais com as mesmas características.

\subsubsection{Resistência à Carbonatação/Permeabilidade a Cloretos}

OHAMA apud AMERICAN CONCRETE INSTITUTE (1995) estudou concretos modificados com látex estireno-butadieno expostos a gás carbônico, e também expostos a soluções com dióxido de carbono. Após a exposição, os corpos-deprova foram abertos diametralmente e a profundidade de carbonatação medida com o uso de reagente à base de fenolfetaleína. Os resultados mostraram que a carbonatação é reduzida sobremaneira nos concretos modificados com látex.

A permeabilidade a cloretos dos concretos modificados com látex pode ser medida por vários testes. OHAMA apud AMERICAN CONCRETE INSTITUTE (1995) conduziu testes onde os cilindros eram submersos em soluções de sais por 28 e 91 dias. A penetração dos cloretos foi medida nos corpos-de-prova rompidos diametralmente, com auxílio de uma solução reagente e se observa a mesma tendência da profundidade de carbonatação. Os baixos valores de permeabilidade e absorção obtidos nos concretos modificados com látex estireno-butadieno acabam por promover proteção contra absorção e permeabilidade a cloretos.

\subsubsection{Durabilidade}

A durabilidade dos compósitos gerados a partir da modificação da argamassa de cimento portland com látex estireno-butadieno é melhorada, proporcionando uma 
melhora no desempenho do material. Segundo BIJEN (1993), as seguintes hipóteses são responsáveis pelo aumento na durabilidade dos materiais modificados:

$\checkmark$ Redução da água livre nos compósitos;

$\checkmark$ Proteção da fibra contra o crescimento da cal, quando utilizada;

$\checkmark$ Redução do ataque alcalino, porque o polímero forma um filme que protege a fibra, pelo menos parcialmente e, esse filme polimérico promove uma redução da quantidade de $\mathrm{Ca}(\mathrm{OH})_{2}$, possivelmente devido à adsorção deste entre os filmes de polímero.

\subsubsection{Forma de Cura}

Quanto à cura dos concretos modificados com látex SB, existe um consenso de que a cura úmida seja o método mais eficaz para os materiais provenientes dessa incorporação. Embora exista esse consenso, vários autores divergem quanto ao tempo de cura úmida a ser aplicado aos elementos.

Alguns autores como TEZUKA (1988), WALTERS (1990), STORTE (1991), SHAKER et al. (1997) e FERREIRA JR. (1997), sugerem que o processo ideal de cura dos concretos modificados com látex de estireno-butadieno é a cura úmida nas primeiras 24 horas após a moldagem, seguido de cura seca, ou seja, sem a presença de água. Já autores como, RAY et al. (1995), recomendam a cura úmida nas primeiras 48 horas, seguido de cura seca.

A melhor forma de cura para concretos modificados com látex estirenobutadieno é a umidade relativa de 100\% nas primeiras 24 a 48 horas, seguidas de cura ao ar (umidade de 50\%, se em laboratório). Durante este período de cura ao ar, qualquer excesso de água evapora e permite a formação do filme que irá preencher a estrutura interna do concreto (BALLISTA, 2003).

“A forma como a cura é executada tem influência direta nas propriedades dos elementos confeccionados com látex. Normalmente, estes elementos requerem um método de cura diferente devido à adição do polímero. As propriedades quase ótimas do sistema modificado são alcançadas por uma combinação de cura úmida, por um determinado número de dias, seguida de cura seca à temperatura ambiente” (GODOY \& BARROS, 1997).

A resistência ótima é obtida alcançando-se uma quantidade razoável de hidratação do cimento sob condições úmidas nos primeiros estágios, seguido de 
condições secas, para promover a formação do filme de polímero devido à coalescência do látex (OHAMA, 1987).

Segundo ROSSIGNOLO et al. (2000), o método de cura que proporciona melhores características aos microconcretos modificados com látex estireno-butadieno é o de cura úmida nas primeiras 24 horas depois da desforma e depois cura seca. Isto porque, decorre da modificação, o efeito de diminuição da permeabilidade que impede a entrada de água no concreto durante o processo de cura úmida, assim como também impede a perda de água para o ambiente. Por isso os processos de cura úmida não são muito eficazes neste tipo de material.

\subsection{Almofadas de apoio de compósito de cimento}

Os estudos com o compósito em questão vêm sendo desenvolvidos há algum tempo no laboratório de estruturas da Escola de Engenharia de São Carlos (EESC/USP), sendo o mesmo utilizado em pesquisas realizadas em ligações de elementos pré-moldados do tipo viga-pilar. MIOTTO (2002) utilizou as almofadas de argamassa em sua pesquisa de doutorado no referido tipo de ligação de elementos de concreto pré-moldados. A Tabela 2.4 apresenta as características dos ensaios realizados utilizando-se a almofada.

Nas vigas do modelo 1, como foram realizados ensaios com e sem a presença da almofada, a pesquisadora pode notar algumas diferenças no início da fissuração, com um retardo no aparecimento quando da presença da almofada e, uma menor fissuração na região de compressão do consolo. Estas variações foram atribuídas a capacidade de acomodação da almofada utilizada como aparelho de apoio e indicando a efetividade da mesma. Para os modelos do tipo 2, os ensaios realizados foram sempre com a presença da almofada de apoio.

Nos dois tipos de modelos ensaiados, a forma do consolo para apoio da viga no pilar foram diferentes, exigindo-se uma adequação do aparelho de apoio à tipologia da ligação, mostrando uma vantagem deste tipo de elemento à base de cimento, que é a capacidade de moldá-lo na forma e modelo que a ligação necessita. 
Tabela 2.4: Ligações viga-pilar estudadas por MIOTTO (2002).

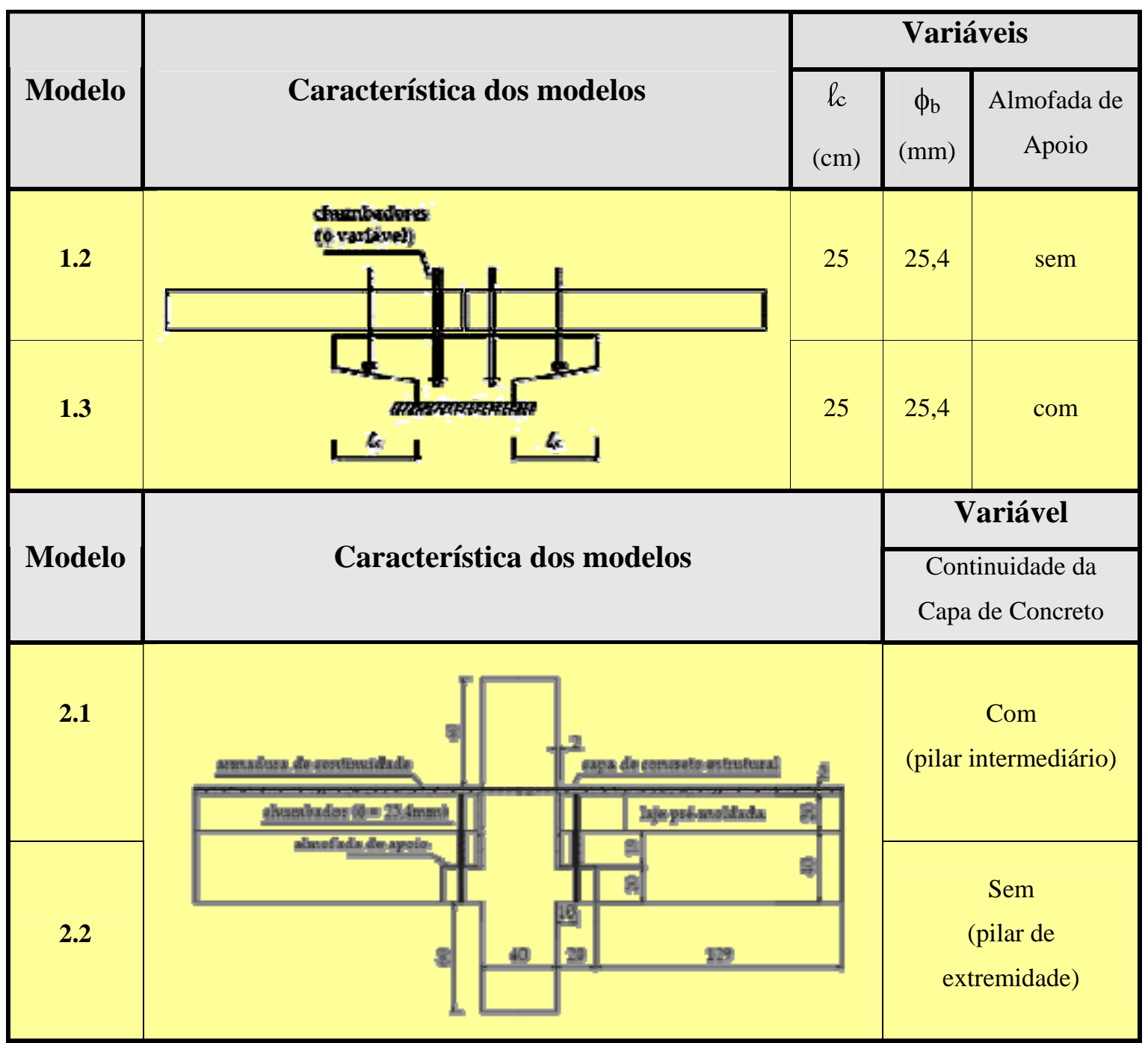

No mesmo ano encontramos o estudo realizado por BARBOZA (2002), onde foram estudadas ligações do tipo pilar-pilar, apresentadas na Figura 2.7.

Como se pode observar foi introduzido, na extremidade dos pilares, um reforço para evitar que estes rompessem prematuramente naquela região. As almofadas de ligação utilizadas possuíam $175 \mathrm{~mm}$ de base, a mesma dimensão dos pilares e, $15 \mathrm{~mm}$ de espessura.

Os resultados dos ensaios mostraram que a utilização das almofadas de argamassa como elemento de apoio para o caso das ligações pilar-pilar tende a ser uma situação intermediária entre a junta de argamassa e o contato direto entre os pilares. Foram utilizadas duas almofadas de compósito, uma delas com 1\% de fibra de polipropileno e 
a outra com 4\% de fibra de PVA. Observou-se que em relação ao valor teoricamente resistido pelo concreto pré-moldado, houve menor aproveitamento para o modelo com almofada de apoio de PVA, apesar do ganho de ductilidade em relação ao modelo com junta de argamassa. Talvez uma almofada com menor teor de fibra proporcionasse melhor comportamento.

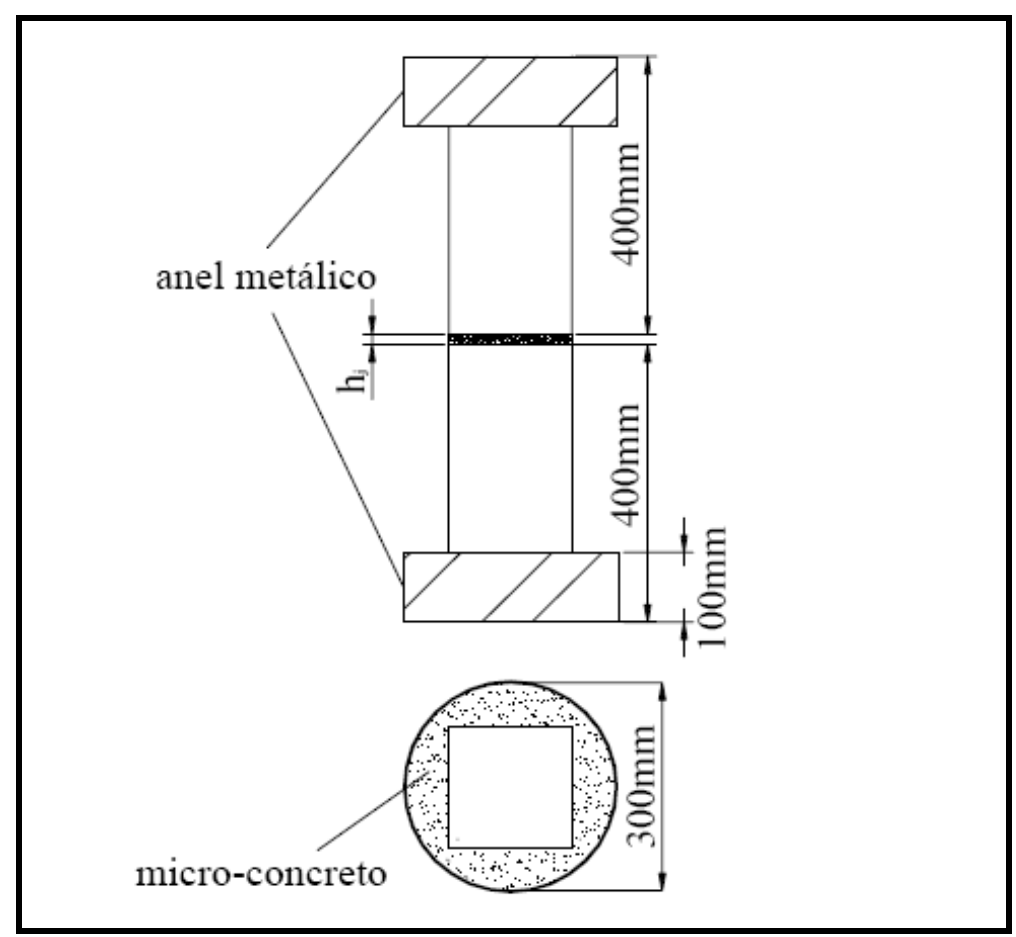

Figura 2.7: Esquema do ensaio de ligação pilar-pilar realizado por BARBOZA (2002).

Constatou-se também que, devido à flexibilidade da almofada de apoio de argamassa, o comportamento das tensões é mais uniforme, conseqüentemente ocorre menos deterioração dos segmentos pré-moldados.

EL DEBS et al. (2003) apresenta uma síntese dos resultados obtidos para as almofadas do compósito. No artigo são apresentados resultados de resistência à compressão, tração e módulo de elasticidade para corpos-de-prova cilíndricos do compósito, bem como resultados da utilização de almofadas em ligações do tipo viga-pilar e do tipo pilar-pilar.

Os resultados obtidos mostram que é possível a obtenção de um material suficientemente deformável para ser utilizado como elemento de apoio de concreto prémoldado. Os resultados da ligação viga-pilar sugerem que, o uso das almofadas do 
compósito produzem ligações mais rígidas e estas características podem ser utilizadas no projeto estrutural. Para o caso da ligação pilar-pilar, os resultados indicaram que as almofadas do compósito podem ser utilizadas em casos onde os elementos prémoldados tenham resistência da ordem de 35MPa.

Na seqüência dos estudos podemos encontrar a pesquisa realizada por MONTEDOR (2004) com almofadas de argamassa modificadas com látex, vermiculita e fibras de PVA e vidro. Sua pesquisa serviu de base para este trabalho e seus resultados são de grande importância no desenvolvimento do material em questão.

$\mathrm{Na}$ primeira parte de seus estudos, o pesquisador determinou as características mecânicas do compósito. Foram estudados 21 traços, sendo moldados 11 corpos-deprova de 50mm x 100mm para cada traço, sendo 04 para determinação da resistência à compressão, 04 para determinação da resistência à tração pelo ensaio de compressão diametral e 03 para ensaio de módulo de elasticidade.

Nestes traços foram sendo estudadas várias combinações de vermiculita, látex estirenobutadieno e fibras de Vidro, PVA e Polipropileno. Na Tabela 2.5 mostra-se os traços estudados pelo pesquisador.

Observando-se a Tabela verifica-se que as concentrações de vermiculita variaram de $0 \%$ a $50 \%$, o látex de $0 \%$ a $40 \%$ e a fibra de $0 \%$ a $4 \%$. Na Tabela 2.6 o padrão de variação dos materiais é mostrado.

De posse dos resultados dos ensaios mecânicos e das dificuldades de incorporação dos materiais encontradas durante a fase de moldagem das peças do compósito, o pesquisador decidiu adotar um traço de referência apresentado na Tabela 2.7.

Essa mistura foi adotada porque com a incorporação de látex maiores que 30\% da massa de cimento houve uma queda acentuada nas resistências dos corpos-de-prova. Essa configuração apresentou também resultados muito interessantes de capacidade de deformação e módulo de elasticidade. 
Devido à diversidade de materiais utilizados na pesquisa, foi necessária a elaboração de uma legenda para identificação dos diferentes traços estudados, da qual, pode-se visualizar o respectivo material e a respectiva quantidade incorporada na amostra, sendo esta mostrada na Tabela 2.8.

Tabela 2.5: Misturas para ensaios de caracterização do material (MONTEDOR, 2004).

\begin{tabular}{|c|c|c|}
\hline $\begin{array}{l}\text { Consumo de } \\
\text { Vermiculita } \\
(\mathrm{em} \%)\end{array}$ & $\begin{array}{c}\text { Taxa } \\
\text { volumétrica de } \\
\text { Látex (em \%) }\end{array}$ & $\begin{array}{l}\text { Taxa volumétrica de } \\
\text { fibra de PVA (em \%) }\end{array}$ \\
\hline 25 & 30 & 3 \\
\hline 25 & 30 & 2 \\
\hline 10 & 30 & 3 \\
\hline 5 & 30 & 3 \\
\hline 0 & 30 & 3 \\
\hline 5 & 0 & 3 \\
\hline 5 & 20 & 2 \\
\hline 5 & 40 & 3 \\
\hline 5 & 30 & 0 \\
\hline 5 & 30 & 1 \\
\hline 5 & 30 & 2 \\
\hline 5 & 30 & 4 \\
\hline 0 & 30 & 2 \\
\hline 0 & 30 & 4 \\
\hline 0 & 40 & 2 \\
\hline 0 & 0 & 0 \\
\hline $\begin{array}{c}\text { Consumo de } \\
\text { Vermiculita } \\
\text { (em \%) }\end{array}$ & $\begin{array}{c}\text { Taxa } \\
\text { volumétrica de } \\
\text { Látex (em \%) }\end{array}$ & $\begin{array}{l}\text { Taxa volumétrica de } \\
\text { fibra de vidro (em \%) }\end{array}$ \\
\hline 50 & 30 & 2 \\
\hline 25 & 30 & 2 \\
\hline 5 & 30 & 2 \\
\hline 5 & 30 & 3 \\
\hline $\begin{array}{c}\text { Consumo de } \\
\text { Vermiculita } \\
\text { (em \%) }\end{array}$ & $\begin{array}{c}\text { Taxa } \\
\text { volumétrica de } \\
\text { Látex (em \%) }\end{array}$ & $\begin{array}{c}\text { Taxa volumétrica de } \\
\text { fibra de polipropileno } \\
\text { (em \%) }\end{array}$ \\
\hline 5 & 30 & 2 \\
\hline
\end{tabular}


Tabela 2.6: Variáveis analisadas.

\begin{tabular}{||c|c|c|c|c|c||}
\hline \hline Variáveis & \multicolumn{6}{|c||}{ Dosagem (\%) } \\
\hline Vermiculita & $\mathbf{5 0}$ & $\mathbf{2 5}$ & $\mathbf{1 0}$ & $\mathbf{5}$ & $\mathbf{0}$ \\
\hline Látex & \multicolumn{2}{|c|}{0} & 20 & $\mathbf{3 0}$ & 40 \\
\hline Fibras & 0 & 1 & 2 & $\mathbf{3}$ & 4 \\
\hline
\end{tabular}

Tabela 2.7: Traço de referência.

\begin{tabular}{||c|c|c|c||}
\hline \hline Cimento & Areia & Látex & Água \\
\hline 1 & 0,3 & 0,3 & 0,1 \\
\hline
\end{tabular}

Tabela 2.8: Legenda dos materiais.

\begin{tabular}{||c|c||}
\hline \hline Legenda & Descrição \\
\hline V +número & Consumo de vermiculita $(\mathrm{em} \%)$ \\
\hline L + número & Taxa volumétrica de látex $(\mathrm{em} \%)$ \\
\hline F + número & Taxa volumétrica de fibra de PVA $(\mathrm{em} \%)$ \\
\hline VD + número & Taxa volumétrica de fibra de vidro $(\mathrm{em} \%)$ \\
\hline PP + número & Taxa volumétrica de fibra de polipropileno $(\mathrm{em} \%)$ \\
\hline
\end{tabular}

Como exemplo de utilização da legenda segue um exemplo de traço utilizado na pesquisa e sua respectiva explicação:

- V5PP2L30: significando que do traço de referência, 5\% da quantidade em massa de areia foi substituída por vermiculita, foi incorporado $2 \%$ de fibra de polipropileno e a quantidade de látex foi mantida em $30 \%$.

Na seqüência do trabalho, foram estudadas as características de placas de argamassa do compósito com 150mm de base e espessuras de $10 \mathrm{~mm}$ e $20 \mathrm{~mm}$. Foram realizados alguns ensaios de compressão centrada sobre as almofadas para determinação da relação entre tensão e deformação do material, chamada nesse trabalho de rigidez de almofada. Os valores dessa rigidez obtida para as almofadas foram bem menores que o de uma argamassa convencional e da ordem de 20 a 25 vezes maiores que a rigidez de uma almofada de neoprene. O esquema do ensaio está mostrado nas figuras 2.8a e 2.8b. 


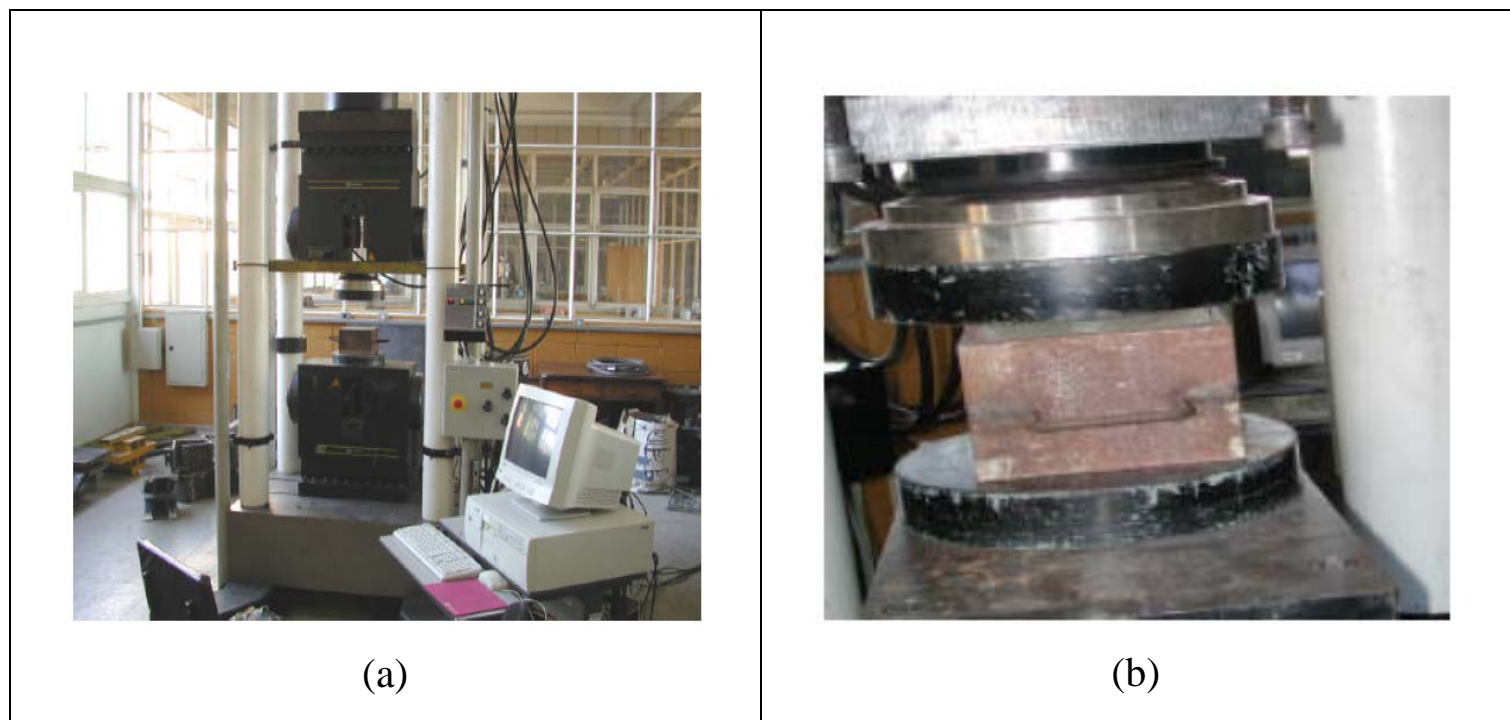

Figura 2.8: a) Máquina de Ensaios e b) Aplicação de carga na almofada (MONTEDOR, 2004).

Para a determinação da capacidade de afundamento da placa foi realizado um ensaio de carga localizada, onde um dispositivo metálico aplicava duas cargas em tiras de150mm de comprimento com largura de $25 \mathrm{~mm}$, cortadas da almofada original de $150 \mathrm{~mm}$. As medidas do afundamento sofrido pela tira foi medido com o auxílio de paquímetro. $\mathrm{O}$ esquema do ensaio está mostrado na Figura 2.9.

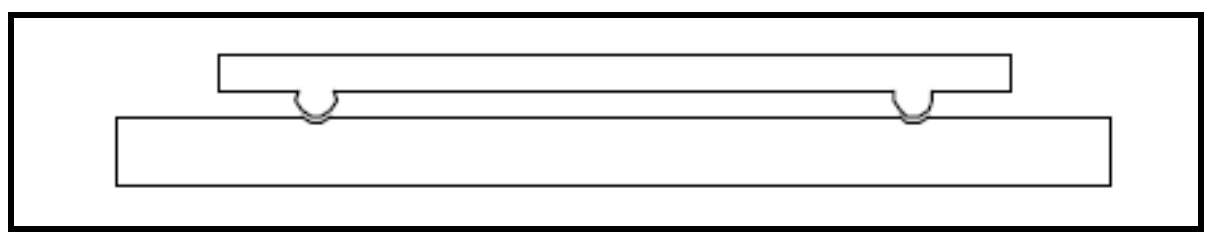

Figura 2.9: Ensaio de carga localizada.

Na fase final de sua pesquisa, MONTEDOR (2004), realizou alguns ensaios que simularam uma ligação pilar-pilar de elementos pré-moldados de concreto com almofada na interface da ligação, denominada no trabalho de ensaio de ligação de bloco, verificando assim, sua capacidade de distribuir as tensões dessa região. Foram realizadas cinco séries de ensaios que estão apresentados na Tabela 2.9. 
Tabela 2.9: Ensaios de ligação de blocos (MONTEDOR, 2004).

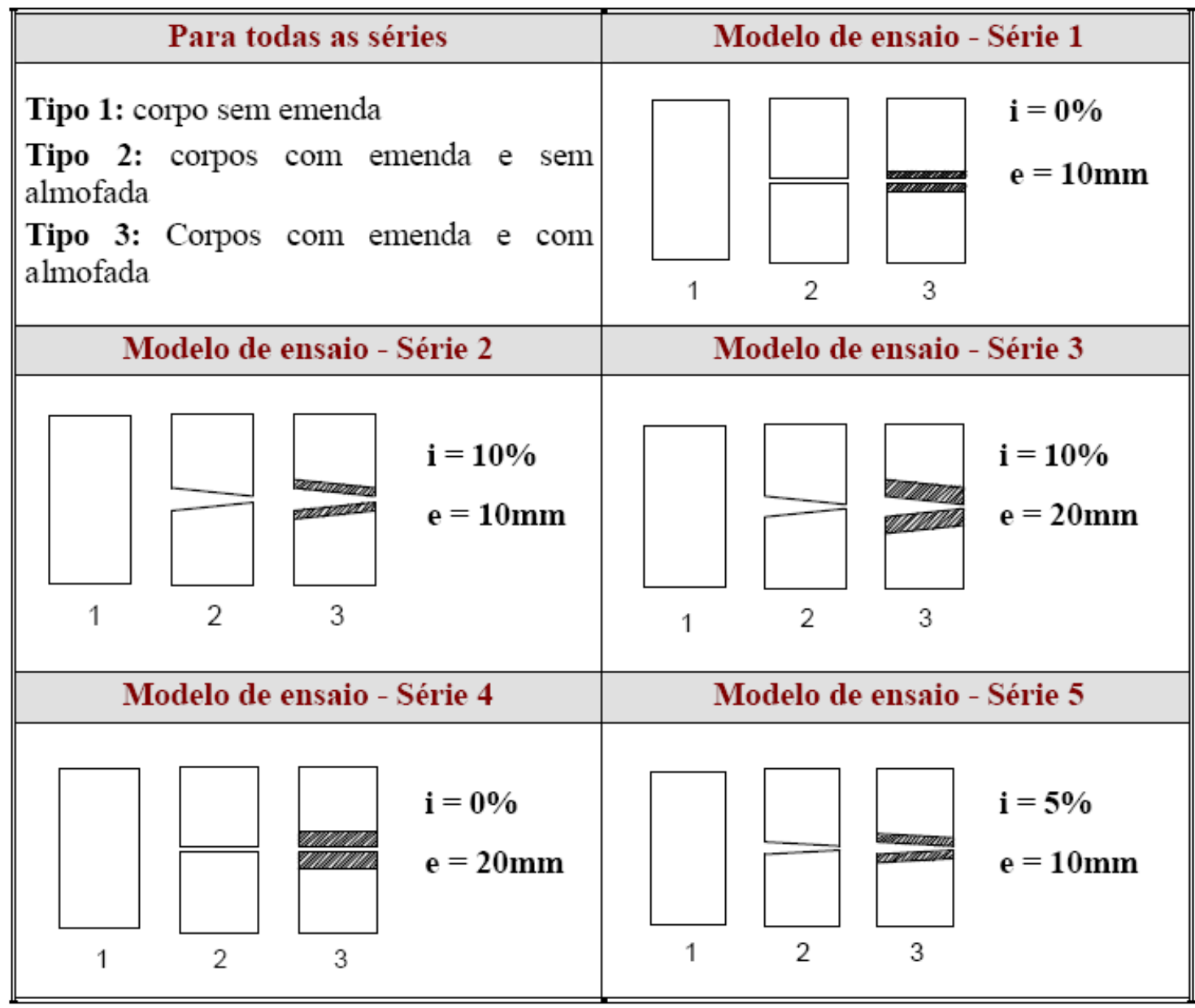

Os elementos estudados eram prismáticos, com 150mm de base com altura de $300 \mathrm{~mm}$ para os blocos sem emenda e cúbicos, com 150mm de lado, onde dois elementos eram sobrepostos e ensaiados conforme mostrado na Tabela anterior.

No caso dos resultados das resistências à compressão e tração e módulo de elasticidade, os resultados são apresentados a seguir nas figuras 2.10, 2.11 e 2.12. 


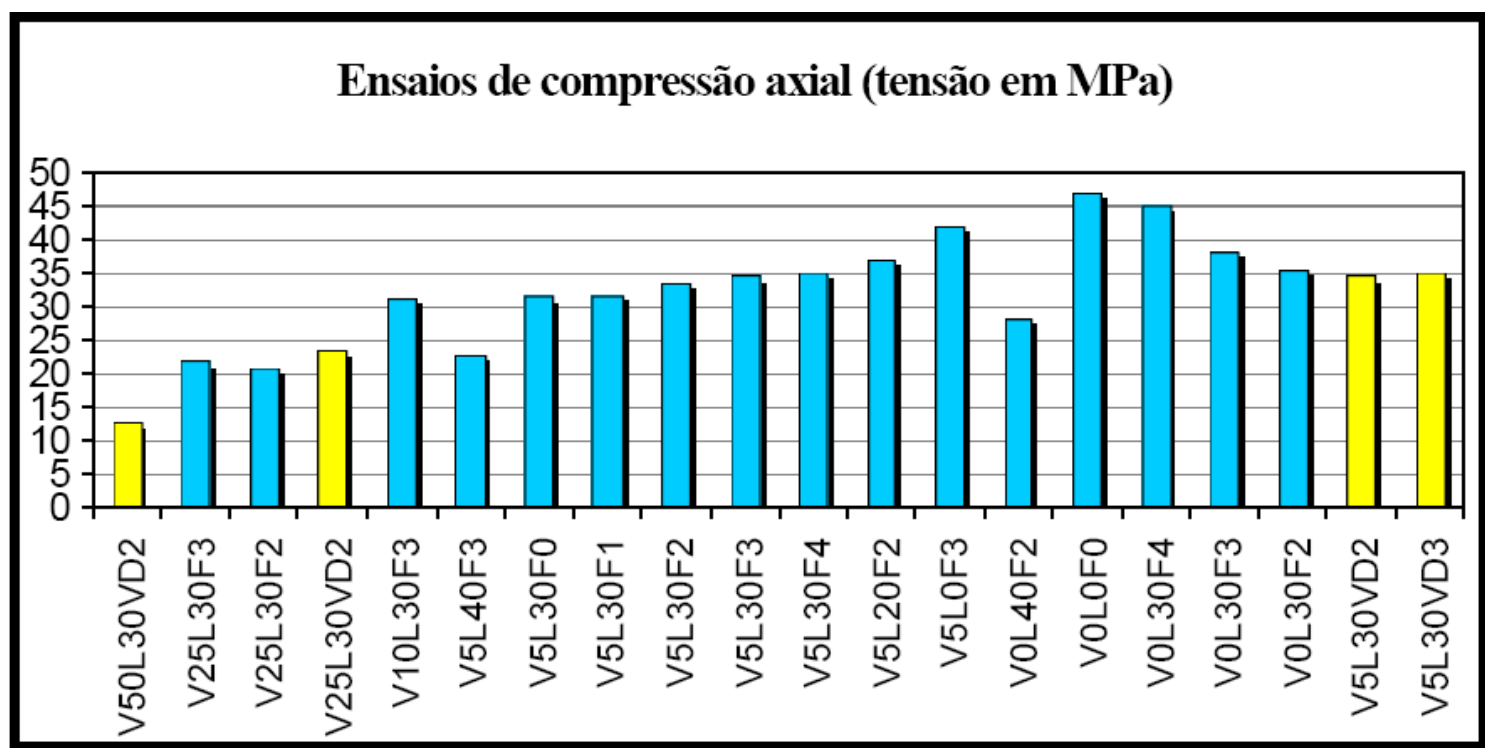

Figura 2.10: Resultados dos ensaios de compressão em corpos-de-prova cilíndricos (MONTEDOR, 2004).

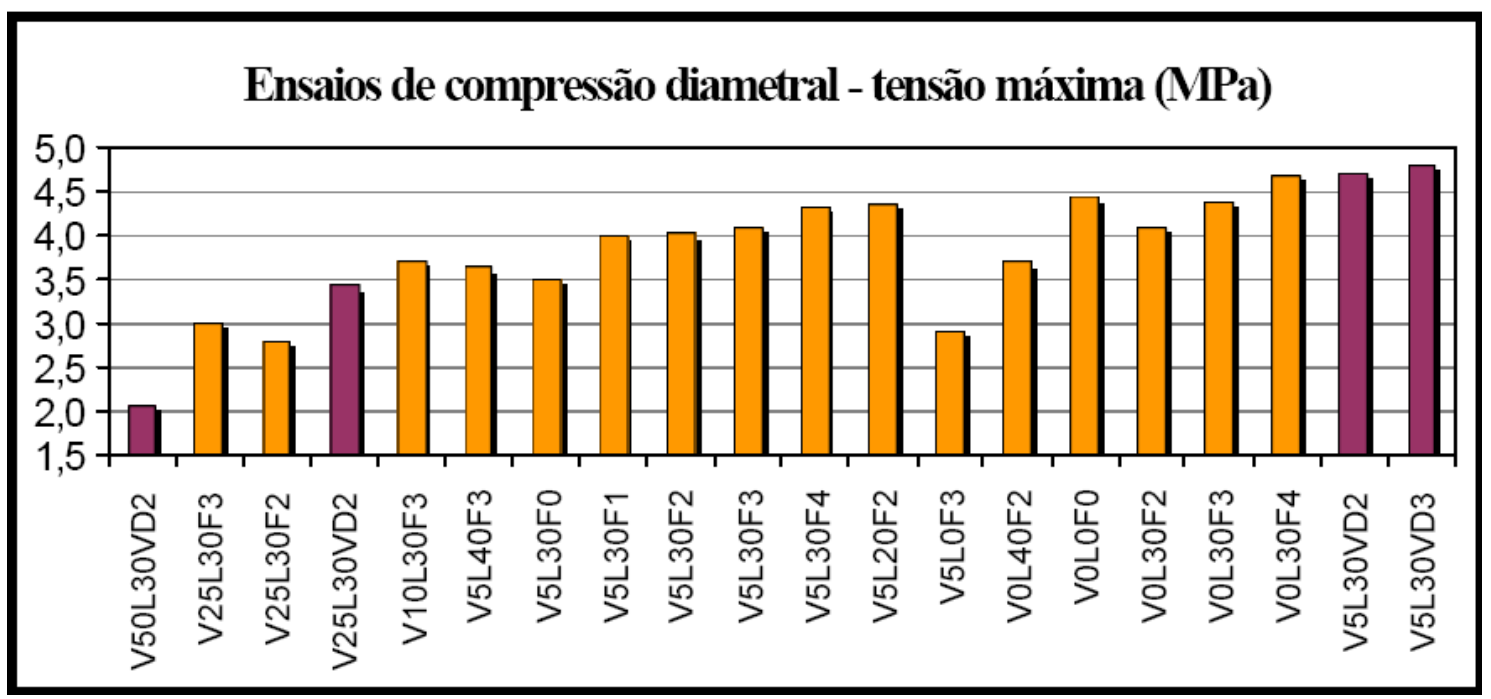

Figura 2.11: Resultados dos ensaios de tração por compressão diametral em corpos-de-prova cilíndricos (MONTEDOR, 2004).

Os resultados obtidos pelo pesquisador mostram que é possível a redução do módulo de elasticidade do compósito com a introdução do látex, fibra e vermiculita, conferindo ao material deformabilidade, característica essa, essencial aos elementos de apoio para concreto pré-moldado. No caso dos ensaios com ligação de blocos, verificou-se que os resultados dos blocos com a presença da almofada e sem inclinação se apresentaram bem próximos aos valores dos elementos sem emenda, mostrando a efetiva contribuição das almofadas na distribuição das tensões. Para o caso das ligações com inclinação, os 
resultados não se apresentaram muito consistentes, necessitando a verificação da capacidade de rotação das almofadas de uma outra maneira, por meio de ensaios realizados especificamente para medir a capacidade de acomodar rotações do compósito.

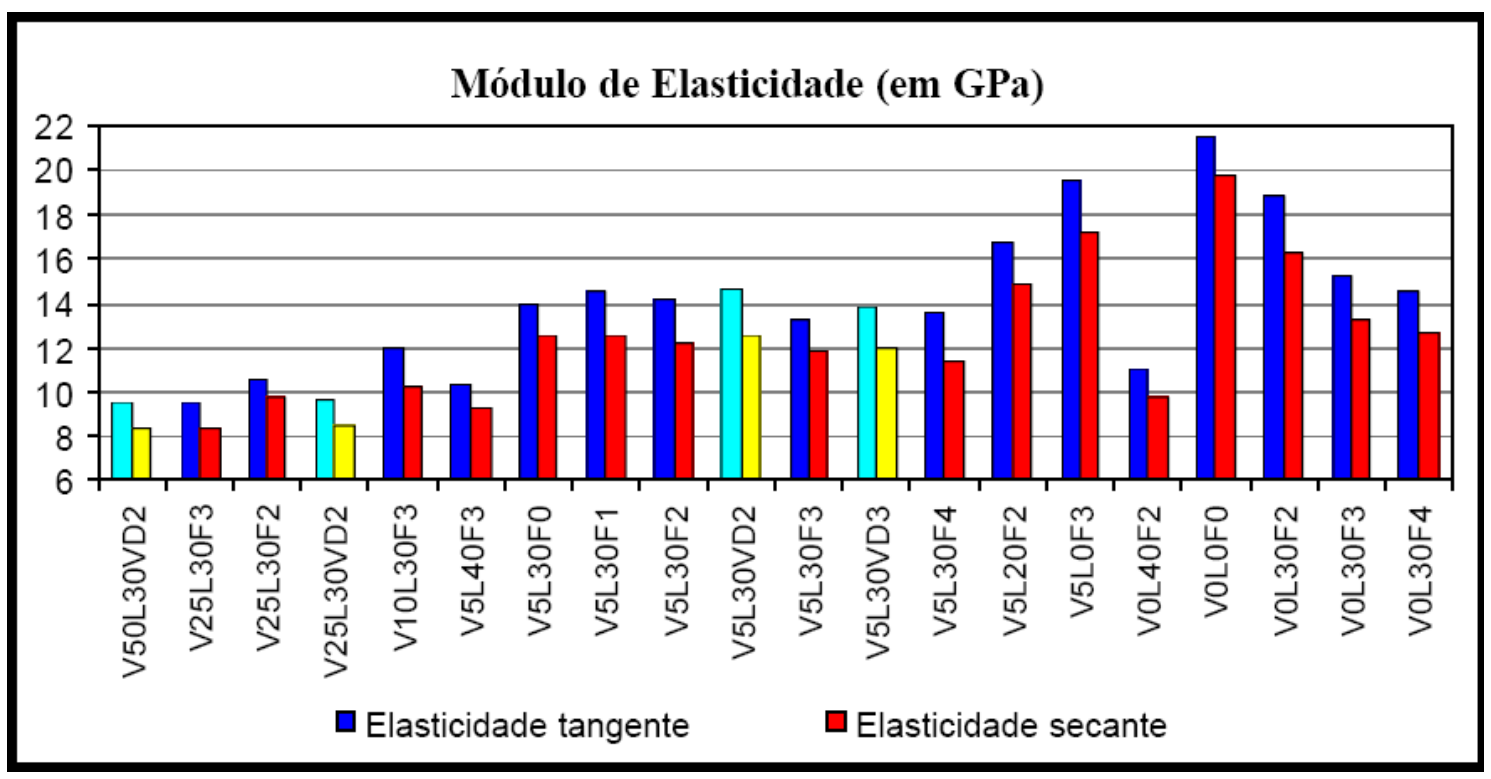

Figura 2.12: Resultados dos ensaios de módulo de elasticidade em corpos-de-prova cilíndricos (MONTEDOR, 2004).

Nas figuras 2.13 e 2.14 são apresentados os principais resultados dos ensaios de compressão centrada em placas do compósito.

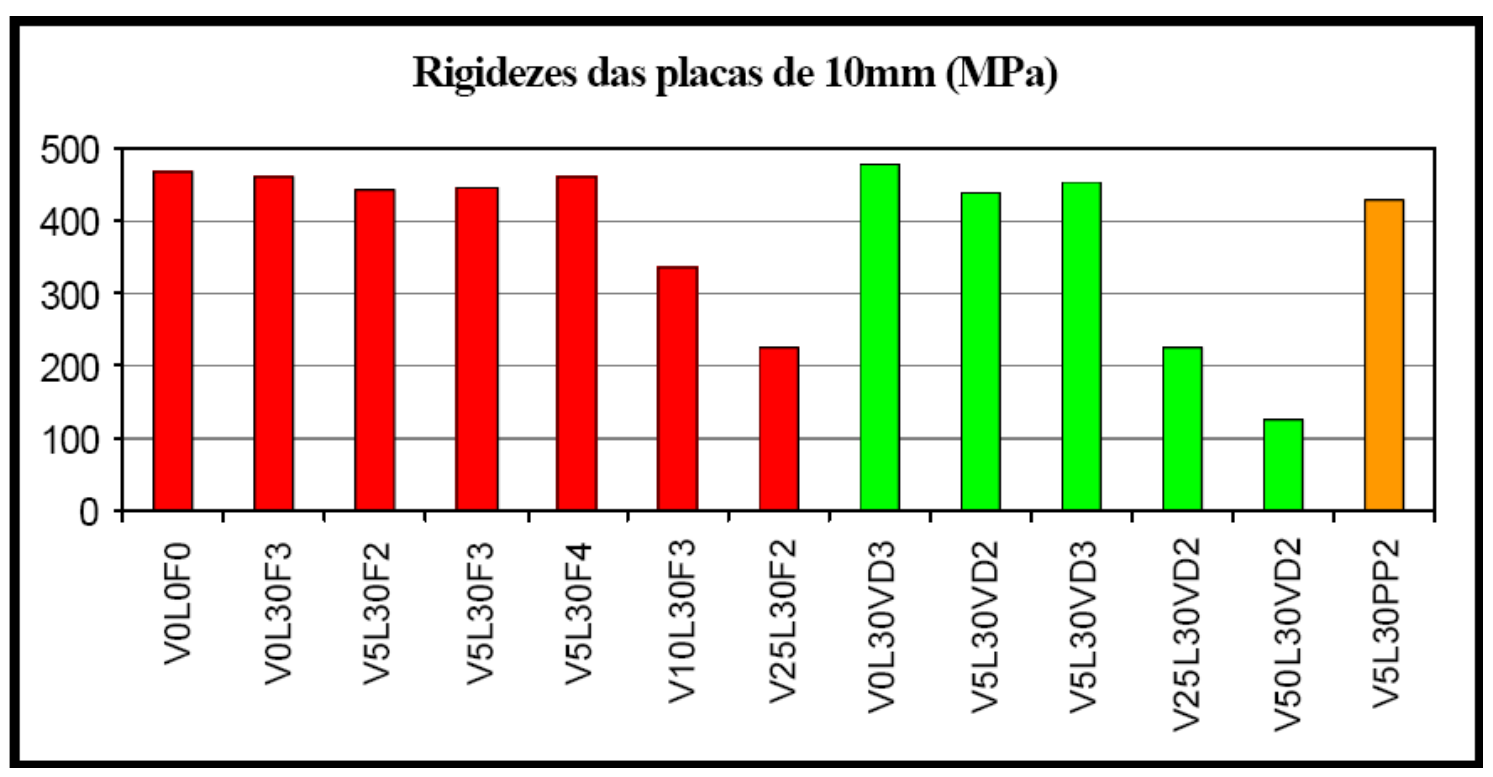

Figura 2.13: Resultados dos ensaios de rigidez de placa (MONTEDOR, 2004). 
A rigidez das placas observada na Figura 2.13 é a relação tensão x deformação para as almofadas do compósito e denota a deformabilidade destas.

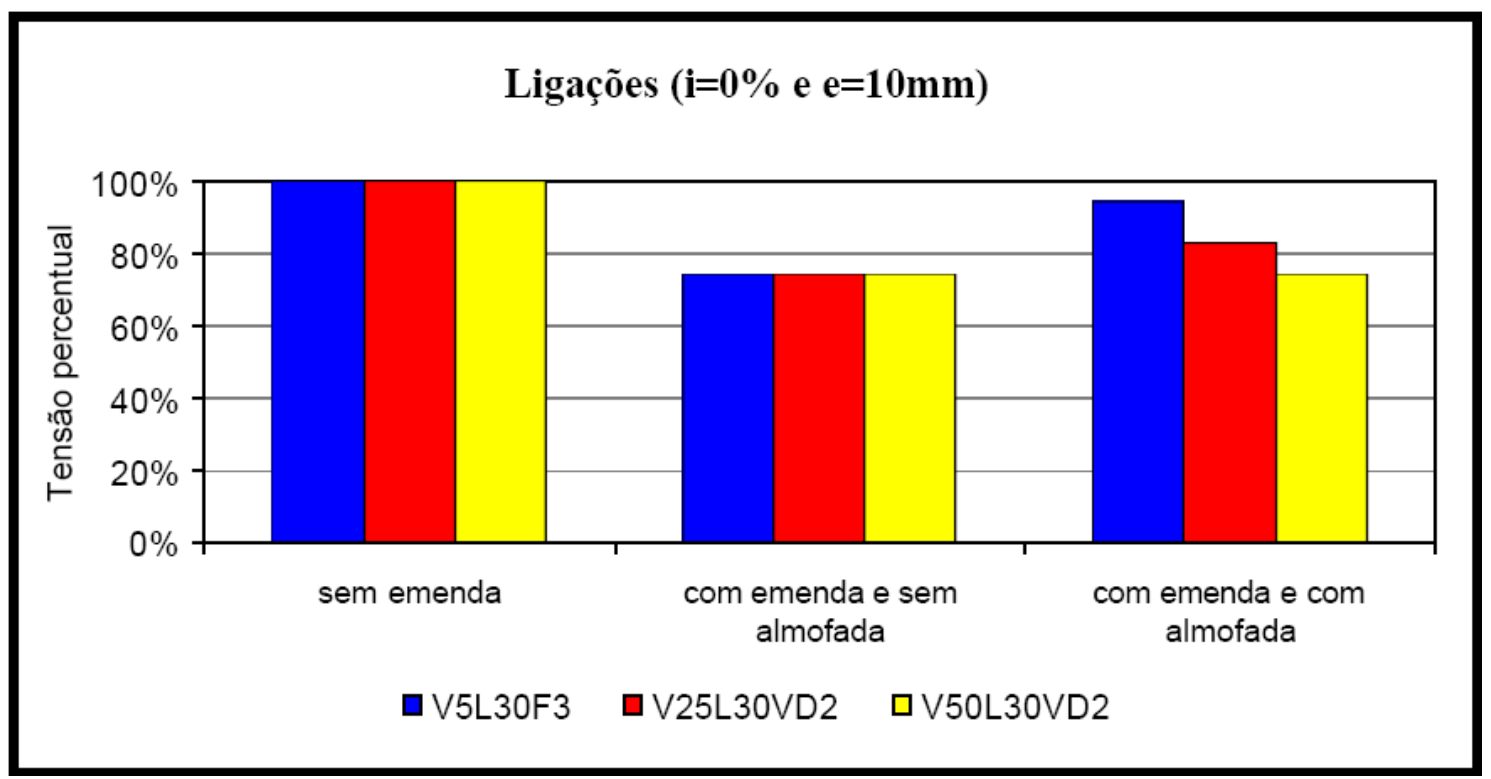

Figura 2.14: Resultados dos ensaios de ligação de blocos com almofadas de $10 \mathrm{~m}$ de espessura e $0 \%$ de inclinação (MONTEDOR, 2004).

Na pesquisa realizada por BALDISSERA (2006), novamente foram utilizadas almofadas do compósito como aparelho de apoio. Os ensaios consistiram em uma reformulação do modelo proposto por MIOTTO (2002) mas agora utilizando um chumbador inclinado na ligação viga-pilar. As variáveis analisadas foram semelhantes às da pesquisa anterior, mudando-se somente o chumbador utilizado, para se tentar criar uma ligação semi-rígida mais eficiente para elementos pré-moldados de concreto. Na Figura 2.15 está mostrado um esquema do ensaio realizado nesta pesquisa.

A utilização da almofada nas ligações é recomendada, apesar de causar uma diminuição na rigidez da ligação, uma vez que diminui a acomodação inicial da ligação e a fissuração da região de compressão do consolo, indicando que sua presença garante uma melhor distribuição das tensões de contato (MIOTTO - 2002). 


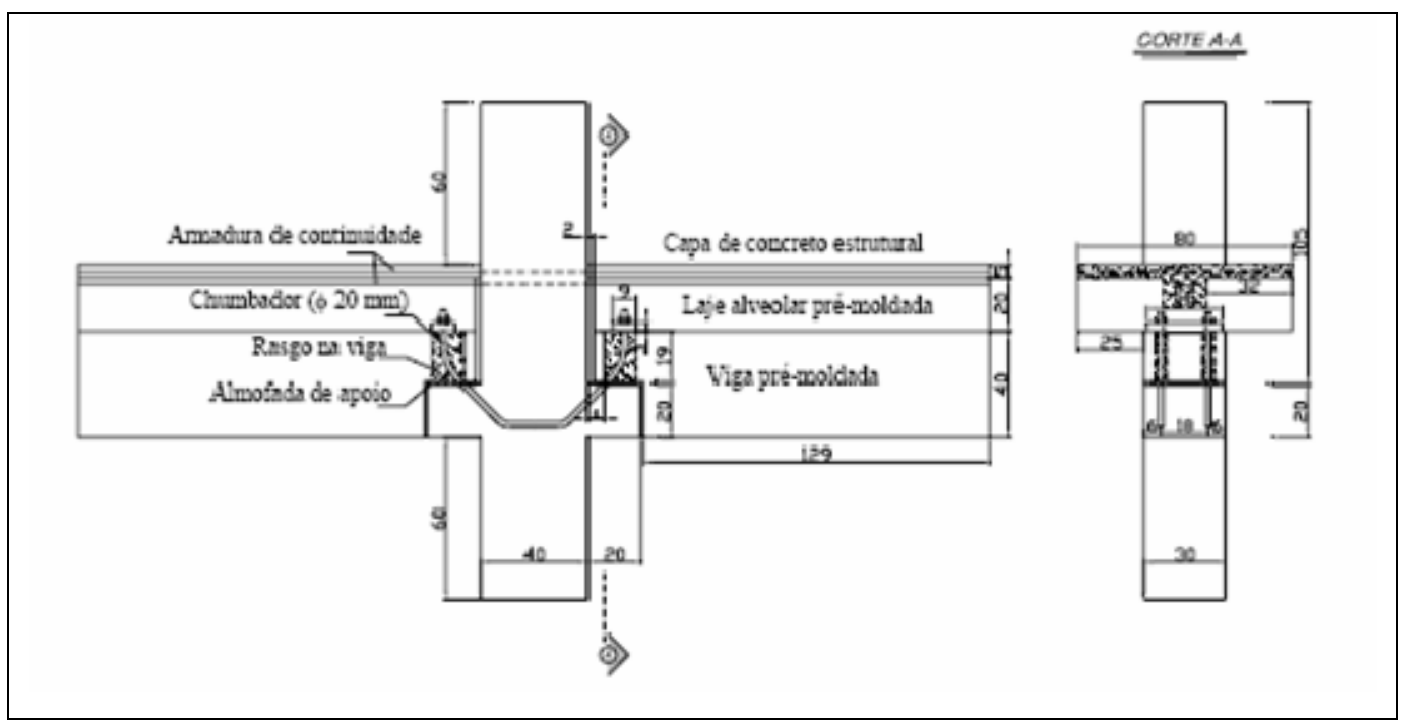

Figura 2.15: Ligação Viga-Pilar estudada por BALDISSERA (2006).

A utilização mais recente do material foi realizada por SOUZA (2006) em ensaios de outra ligação semi-rígida de elementos pré-moldados de concreto. A pesquisa consistiu basicamente da obtenção da rigidez da ligação por meio da investigação experimental do comportamento das vigas pré-moldadas em conjunto com a influência do desempenho da ligação semi-rígida. Para tanto, ao invés de promover um isolamento da região da ligação, como encontrado na literatura, foi realizado um ensaio onde a viga também foi analisada na obtenção dos resultados da pesquisa. O esquema do ensaio proposto está mostrado na Figura 2.16.

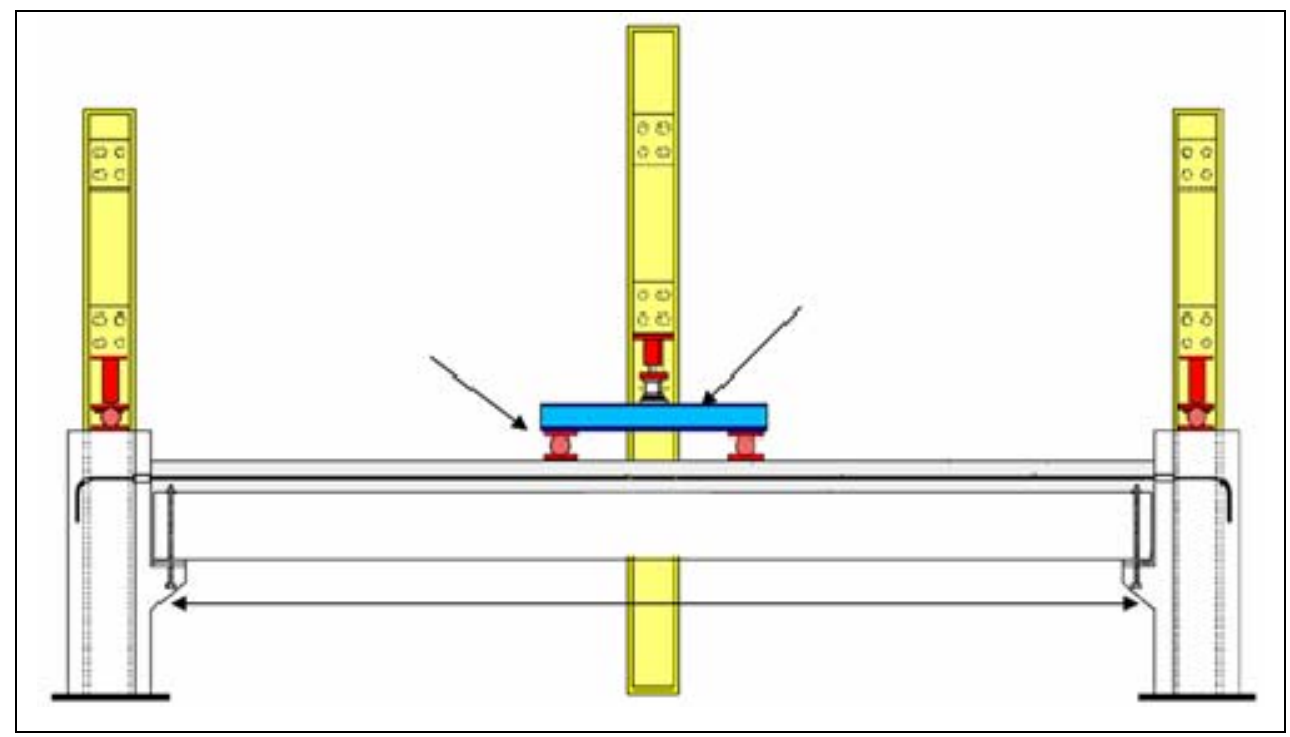

Figura 2.16: Ligação Viga-Pilar estudada por SOUZA (2006). 



\section{Materiais Utilizados}

\subsection{Preliminares}

Este capítulo aborda os materiais utilizados nesta pesquisa, trazendo suas características de acordo com as especificações e algumas de suas propriedades básicas. Também são abordados os parâmetros adotados na dosagem do compósito e as variáveis analisadas para se obter um elemento tão deformável quanto possível. Para encerrar, é apresentada a caracterização das propriedades mecânicas do compósito por meio das suas resistências à compressão, tração e módulo de deformação.

\subsection{Materiais utilizados}

\subsubsection{Cimento Portland}

O cimento Portland é composto sobretudo de material calcário, como rocha calcária ou gesso, alumina e sílica, que podem ser encontrados em argilas e xisto. As argilas contêm também alumina $\left(\mathrm{Al}_{2} \mathrm{O}_{3}\right)$ e, freqüentemente, óxidos de ferro $\left(\mathrm{Fe}_{2} \mathrm{O}_{3}\right)$ e álcalis. $\mathrm{A}$ presença da alumina, dos óxidos de ferro e magnésio e dos álcalis na mistura de matérias-primas tem efeito mineralizante na formação de silicatos de cálcio. Quando não estão presentes quantidades suficientes de alumina e óxido de ferro nas matériasprimas principais, estes são propositalmente incorporados à mistura por adição de materiais secundários, como a bauxita e o minério de ferro (MEHTA \& MONTEIRO, 1994).

O cimento utilizado neste projeto é o de alta resistência inicial (CP-V-ARI). O desenvolvimento desse tipo de cimento é conseguido pela utilização de uma dosagem diferente na produção do clínquer, bem como pela moagem mais fina do cimento, de 
forma que, ao reagir com a água, ele adquire elevadas resistências, com maior velocidade (KATTAR \& ALMEIDA, 1999). As características do cimento utilizado estão mostradas na Tabela 3.1, destacando-se que o mesmo é produzido pela HOLCIM S.A. e comercializado como CIMINAS.

Tabela 3.1: Características do cimento utilizado (Fonte: HOLCIM S.A.)

\begin{tabular}{ccc}
\hline Características & Unidade & CP V ARI \\
\hline Finuıra de Blaine (NBR 7224/1984) & $\mathrm{cm}^{2} / \mathrm{g}$ & 4687 \\
Início de Pega (NBR 11581) & min & 130 \\
Fim de Pega (NBR 11581) & min & 210 \\
Resistência 1 diaa (NBR 7215/1982) & $\mathrm{MPa}$ & 27,7 \\
Resistência 3 dias (NBR 7215/1982) & $\mathrm{MPa}$ & 42,0 \\
Resistência 7 dias (NBR 7215/1982) & $\mathrm{MPa}$ & 46,7 \\
Resistência 28 dias (NBR 7215/1982) & $\mathrm{MPa}$ & 56,1 \\
\hline
\end{tabular}

Este tipo de cimento aqui relacionado obtém suas características de tempo de pega e endurecimento rápido a partir da formação de grande quantidade de etringita durante o período inicial de hidratação. Neste tipo de cimento, o $C_{4} A_{3} \bar{S}$ é principal fonte de aluminato para a formação de etringita e junto do $C_{4} A F$ fornece os íons aluminato. Este tipo de cimento apresenta taxas de resistência de cimento apropriadas para aplicação em produtos de concretos pré-moldados e protendidos, já que nesses casos a ciclagem rápida de fôrmas e moldes é uma necessidade econômica (MEHTA \& MONTEIRO, 1994).

\subsubsection{Areia}

A areia utilizada foi retirada do rio Mogi Guaçu, próximo a São Carlos. O material utilizado é o mesmo da pesquisa realizada por MONTEDOR (2004) e os resultados fornecidos por ele foram aproveitados na obtenção da curva granulométrica, a massa unitária e a massa específica do agregado. O valor da massa específica da areia é de $2,63 \mathrm{~g} / \mathrm{cm}^{3}$. Já sua massa unitária tem como valor $1,50 \mathrm{~g} / \mathrm{cm}^{3}$. Para determinação desses parâmetros, seguiram-se as prescrições da NBR 7251 (1982) e da NBR 9776 (1987). O 
diâmetro máximo característico da areia é igual a 2,4mm e seu módulo de finura equivale a 2,29. Na Figura 3.1 é apresentada a curva granulométrica da areia utilizada.

Nesta pesquisa, na confecção das almofadas de argamassa, toda areia utilizada foi passada na peneira $0,6 \mathrm{~mm}$, que foi praticado devido aos resultados da pesquisa anterior que mostraram uma melhor adequação dessa areia no estudo das propriedades da argamassa.

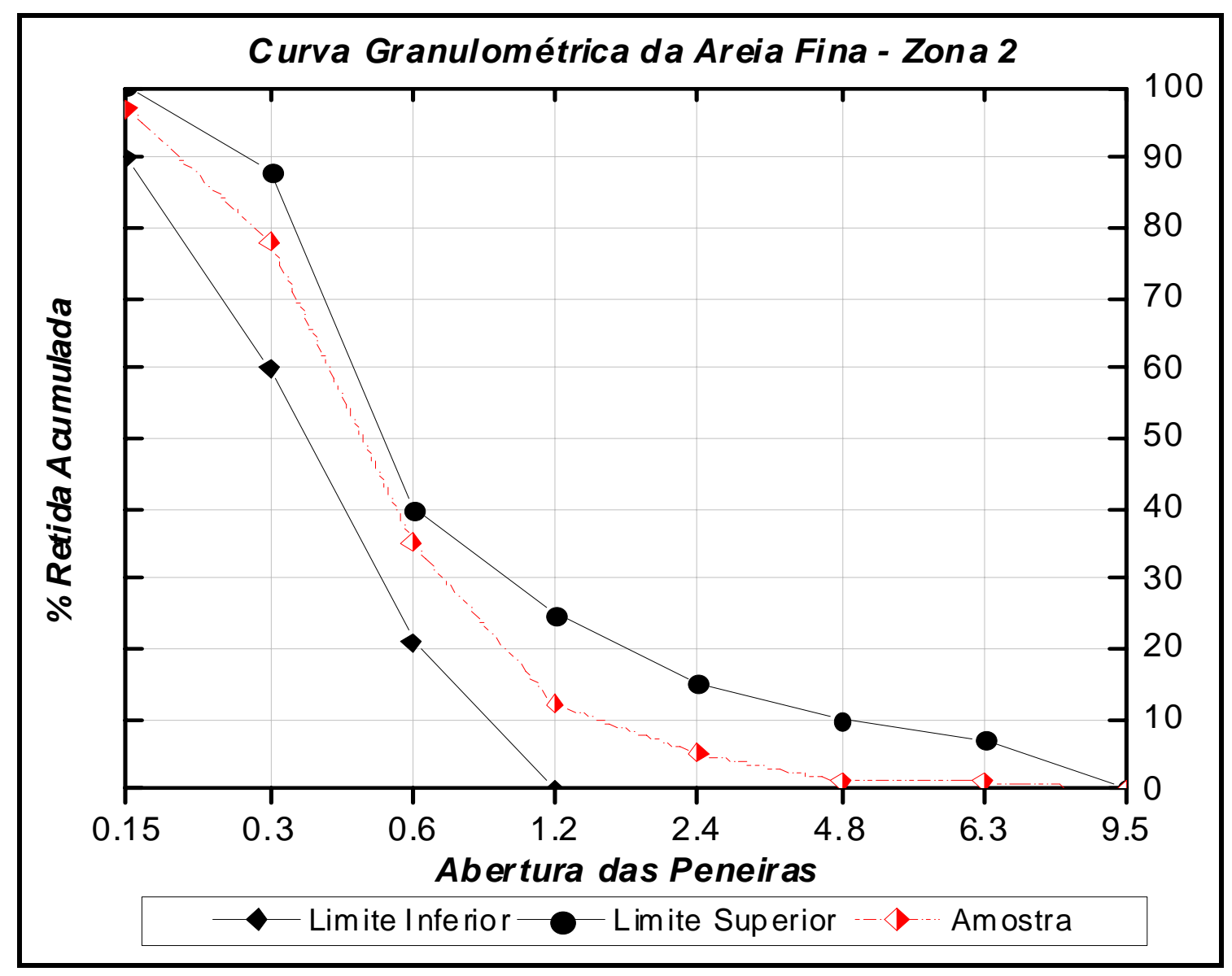

Figura 3.1: Curva Granulométrica da Areia utilizada nos ensaios.

\subsubsection{Vermiculita termo-expandida}

A vermiculita é um mineral cujos cristais são formados por finíssimas lamínulas superpostas, que quando submetidas a temperatura de aproximadamente $1000^{\circ} \mathrm{C}$, expandem-se constituindo a VERMICULITA EXPANDIDA, que tem múltiplas e interessantes utilizações em vários setores da atividade humana. 
Dentre os principais usos na construção civil, está a sua aplicação como eficiente isolante térmico-acústico, graças à baixa condutividade térmica e pequena propagação sonora, além da freqüente utilização como redutor de peso de estruturas de concreto em função do seu reduzido peso específico. Na presença deste material ocorre uma redução do módulo de elasticidade, em razão da presença de uma grande quantidade de células de ar, característica essa de grande importância para o material que está sendo estudado.

Quando submetida a altas temperaturas, a vermiculita perde água intersticial e as lâminas se expandem, transformando-se em flocos que formam células de ar, que lhe proporcionam um bom isolamento termo-acústico e baixa massa específica. Em seu estado bruto possui a cor escura, sendo que após aquecimento e expansão passa a ter coloração dourada, como pode ser visualizado na Figura 2.8.
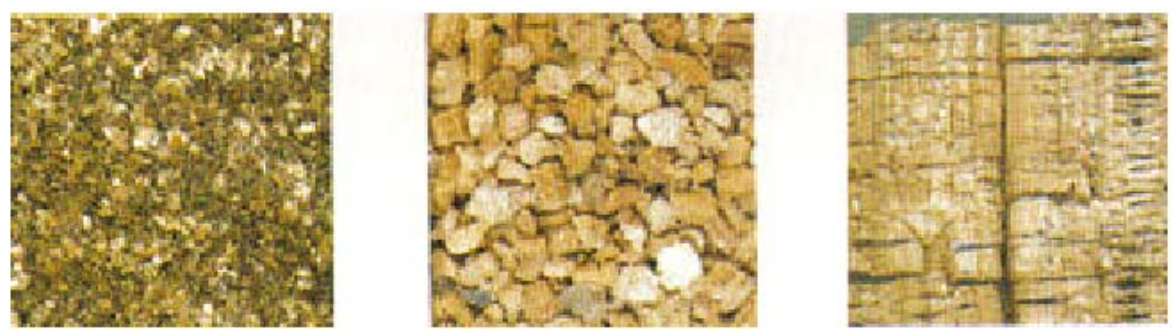

Figura 3.2: Vermiculita: natural, expandida e partícula expandida.

O produto é inífugo, inodoro, não irrita a pele nem os pulmões, não conduz eletricidade, é isolante térmico e absorvente acústico; não se decompõe, deteriora ou apodrece; não atrai cupins ou insetos; é somente atacado pelo ácido fluorídrico a quente; pode absorver até cinco vezes a sua massa em água, é lubrificante e tem as características necessárias aos materiais filtrantes.

O nome vermiculita vem do latim vermiculare, pois ao ser aquecida quando do processo de fabricação, sua aparência lembra a de “vermes”. 
A vermiculita é um material bastante semelhante à mica, formada essencialmente por silicatos hidratados de alumínio e magnésio. Quando submetida a um aquecimento adequado, a água contida entre suas milhares de lâminas se transforma em vapor, fazendo com que as partículas explodam e se transformem em blocos sanfonados. Cada bloco expandido aprisiona consigo células de ar, o que confere ao material excepcional capacidade de isolação.

Para a confecção dos compósitos aqui estudados utilizou-se a vermiculita do tipo termoexpandida, cujas propriedades são apresentadas a seguir:

\section{$\checkmark$ Não tóxica}

\section{$\checkmark$ Absolutamente inorgânica \\ $\checkmark$ Não abrasiva (dureza mohs: 1,5 ) \\ $\checkmark$ Não solúvel em bases e ácidos fracos e solventes orgânicos \\ $\checkmark$ Ponto de fusão $1.300^{\circ} \mathrm{C}$ \\ $\checkmark$ PH praticamente neutro}

A vermiculita utilizada na confecção das almofadas e corpos-de-prova para a realização dos ensaios é do mesmo lote utilizado na pesquisa realizada por MONTEDOR (2004), onde, este pesquisador realizou ensaios de duas amostras do material, nos quais se observou a diferença na dimensão máxima dos grãos. Uma amostra continha grãos que foram retidos na peneira com abertura de 4,8mm, sendo classificado como agregado graúdo e a outra amostra estudada possuía grãos visualmente menores que 4,8mm, não sendo retidos na peneira com esta malha, sendo classificado, portanto, como agregado miúdo.

Realizados os ensaios de determinação granulométrica nas amostras, obtiveram-se as curvas granulométricas de cada uma delas utilizando um conjunto de peneiras padronizadas.

Optou-se por utilizar o agregado miúdo, cuja curva granulométrica é mostrada na Figura 3.3, para a realização das moldagens e ensaios referentes a este trabalho. 


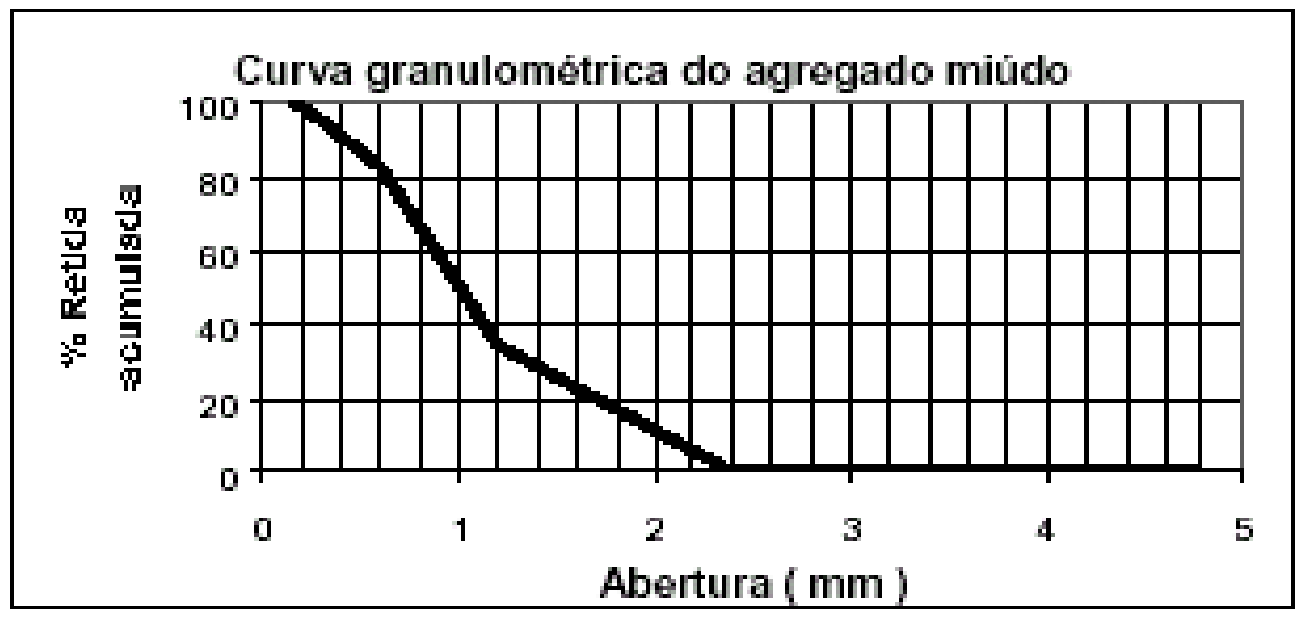

Figura 3.3: Curva granulométrica da vermiculita (Fonte: MONTEDOR, 2004).

\subsubsection{Látex estireno-butadieno}

O látex utilizado nos experimentos até aqui realizados foi o estireno-butadieno SB 112, fornecido pela empresa Rhodia do Brasil e suas características são apresentadas na Tabela 3.2. Optou-se pela utilização deste tipo de emulsão de látex (50\% de água) em razão de sua disponibilidade no Laboratório de Estruturas.

Tabela 3.2: Propriedades do látex estireno-butadieno (Rhodia do Brasil).

\begin{tabular}{rl}
\hline Propriedades & Valores \\
\hline Teor de sólidos & $50 \%$ \\
Massa específica a $25^{\circ} \mathrm{C}$ & $1,02 \mathrm{~kg} / \mathrm{dm}^{3}$ \\
Viscosidade Brookfield & $300 \mathrm{cps}$ \\
$\left(\mathrm{LVT} 2 / 30\right.$ a $\left.23^{\circ} \mathrm{C}\right)$ & \\
$\mathrm{pH}$ & 9,0 \\
Estabilizador & Aniônico \\
Aspecto & Leitoso \\
\hline
\end{tabular}

Quando incorporado à mistura, durante a moldagem dos corpos-de-prova e almofadas, atribui a esta uma cor roxa. As propriedades da incorporação deste nas argamassas já foram discutidas anteriormente. 


\subsubsection{Fibra de Polipropileno}

Dentre as fibras sintéticas utilizadas, o polipropileno oferece o menor custo comparando-se com fibras de poliamida, poliéster, entre outras. O uso de fibras de polipropileno em substituição a outros tipos de fibra (aço e mineral) ainda é pouco explorado. Como o polipropileno é hidrofóbico, sua introdução no concreto não afeta o processo de hidratação da pasta de cimento, mas, ao mesmo tempo, impede a formação de ligações fortes entre a fibra e a matriz cimentícia. No entanto, BENTUR et al. (1989) sugerem a contribuição de dois efeitos na interação fibra-cimento: adesão interfacial e interação mecânica, dos quais o segundo efeito está associado a fatores como separação das fibras em multifilamentos durante a mistura do concreto, ramificação das fibrilas e formação de minúsculas fibrilas na superfície da fibra, contribuindo para a conexão entre a fibra e a matriz de cimento.

A fibra de polipropileno é formada de macrocélulas lineares saturadas de hidrocarbonetos das quais um carbono, entre cada dois, comporta uma ramificação metila, em disposição estática e sem substituições ulteriores. Esta fibra incorporada ao concreto reduz substancialmente as fissuras de retração plástica, reduz a permeabilidade e promove o aumento da resistência ao impacto, à abrasão e ao congelamento, proporcionando aumento da durabilidade do concreto, além de aumentarem a resistência à fadiga e a fragmentação.

Segundo JIANG \& ROY (1992), a utilização de 2\% de fibra de polipropileno na elaboração de amostras de concreto, mostram que a adição das mesmas, interrompem ou desviam a propagação de microfissuras, sendo isso equivalente a uma melhora na resistência à tração. A interrupção das microfissuras também é observada por SHAH (1991) em concretos contendo fibras de polipropileno.

Ainda são reduzidos os estudos sobre a zona de transição entre fibras de polipropileno e pasta de cimento Portland. Como possibilidade de utilização destacam-se as fibras fibriladas e a utilização de aditivos redutores de água para a matriz, já que as fibras fibriladas tendem a incorporar significativo volume de vazios, o que acaba por anular o efeito positivo do aumento da área superficial de contato com a matriz, no caso de fibras curtas (CURRIE; GARDINER, 1989). 
As fibras utilizadas neste trabalho foram doadas pela Fitesa S.A., cortadas com comprimentos de $6 \mathrm{~mm}$ e $12 \mathrm{~mm}$ e possuem uma espécie de rugosidade provocada pela corrugação dos filamentos de maneira a melhorar a adesão entre a fibra e a pasta de cimento, é o chamado fibrilamento. A Figura 3.4 mostra o aspecto da fibra utilizada e as principais características da fibra de polipropileno são apresentadas na Tabela 3.3.

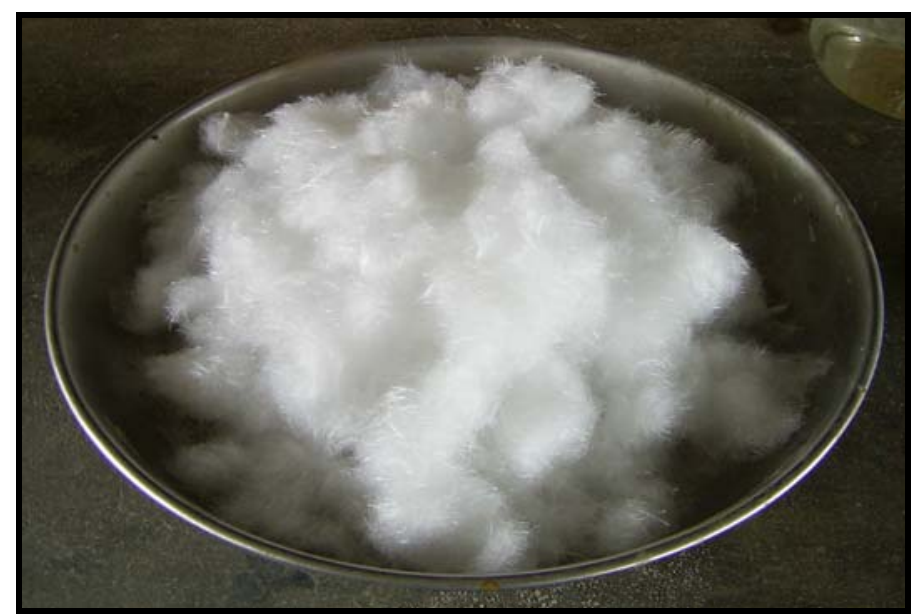

Figura 3.4: Fibras de polipropileno.

Tabela 3.3: Propriedades das fibras de polipropileno (Fonte: Fitesa S.A.).

\begin{aligned} & \hline Dados Técnicos Polipropileno \\ & \hline Base química: Polipropileno \\ & Aspecto: Filamentos Finos \\ & Cor: Branco \\ & Peso específico: $90 \mathrm{~g} / \mathrm{cm}^{3} \\ &$ Ponto de fusão: $165^{\circ} \mathrm{C} \\ &$ Diâmetro: $20 \mathrm{microns} \\ &$ Comprimento: $6,0 \mathrm{~mm} \\ &$ Condutvidade térmica: Nula \\ & Área específica: $255 \mathrm{~m}^{2} / \mathrm{kg} \\ &$ Tensão de ruptura: $810 \mathrm{MPa} \\ &$ Alongamento: $28 \% \\ &$\hline\end{aligned}




\subsubsection{Aditivo Superplastificante}

Aditivo diz respeito a todo produto acrescentado em uma matriz, em quantidades geralmente pequenas e bem homogeneizadas, que reforça ou melhora determinadas características do compósito.

Os tipos mais comuns de aditivos, aplicados em larga escala em concretos ou argamassas, são os seguintes: incorporadores de ar; redutores de água; retardadores e aceleradores de pega; e os superplastificantes.

Os aditivos superplastificantes geralmente são utilizados para que se possa promover uma redução de água de amassamento da mistura. No caso específico desta pesquisa, a redução da relação água/cimento não foi o foco principal pelo qual se optou pela utilização do superplastificante, mas sim, em razão de alguns traços não adquirirem a trabalhabilidade adequada (dificuldades para moldar a mistura). A incorporação deste foi pradronizada em $1 \%$ da massa de cimento para todos os traços que estão sendo estudados, visto que, sua utilização potencializa os efeitos promovidos pela modificação da argamassa com látex, melhorando as características do compósito por adição dos efeitos do látex e do superplastificante simultaneamente.

O superplastificante utilizado nesta pesquisa é o GLENIUM 51, um aditivo de última geração com base em uma cadeia de éter carboxílico modificado. Este aditivo foi desenvolvido para concreto em geral, especialmente para indústria de pré-moldados e concretos protendidos, onde se requer maior durabilidade e desempenho. O GLENIUM 51 é isento de cloretos e atende as prescrições da norma ASTM C 494 (tipos A e F), ASTM C 1017, e é compatível com todos os cimentos que atendem a ASTM 150.

Sua atuação é efetiva tanto no estado fresco como no estado endurecido. As propriedades e benefícios na utilização deste tipo de aditivo são, de acordo com o catálogo do fabricante: 


\section{Estado Fresco:}

$\checkmark$ Alta taxa de redução de água (40\% aproximadamente);

$\checkmark$ Melhora a aderência e textura da superfície do concreto;

$\checkmark$ Produz concretos coesivos porém trabalháveis;

$\checkmark$ Reduz a exsudação.

\section{Estado Endurecido:}

$\checkmark$ Alta resistência à compressão axial inicial e final;

$\checkmark$ Alta resistência à tração na flexão inicial e final;

$\checkmark$ Aumenta o módulo de elasticidade;

$\checkmark$ Redução de permeabilidade.

As alterações que este promove no estado endurecido podem ser verificadas devido à diminuição da relação água/cimento, como dito anteriormente, melhorando as características mecânicas do compósito.

O que diferencia o GLENIUM 51 dos aditivos superplastificantes tradicionais (a base de NSF ou MSF) é um novo mecanismo único de ações que melhora sensivelmente a dispersão das partículas de cimento. Os tradicionais, tais como os sulfonatos de melamina e naftaleno são baseados em polímeros que são absorvidos pelas partículas de cimento. Acumulam-se na superfície das partículas de cimento no início do processo de mistura do concreto. Os grupos sulfônicos das cadeias de polímeros aumentam a carga negativa da superfície das partículas de cimento e dispersam estas por repulsão elétrica. Este mecanismo eletrostático causa a dispersão da pasta de cimento e a conseqüência positiva é que se requer menos água na mistura para se obter uma determinada consistência do concreto.

O GLENIUM 51 tem uma estrutura química diferente da estrutura dos superplastificantes tradicionais. Consiste de polímeros de éter carboxílico com largas cadeias laterais. No começo do processo de mistura, inicia-se o mesmo mecanismo de dispersão eletrostática que os tradicionais, porém as cadeias laterais unidas à estrutura polimérica geram uma energia que estabiliza a capacidade de refração e dispersão das partículas de cimento. Com este processo obtém-se um concreto fluido com uma grande redução da quantidade de água. A Tabela 3.4 mostra os dados técnicos sobre o produto. 
Tabela 3.4: Características do Glenium 51 (Fonte: Catálogo Técnico do Fabricante).

\begin{aligned} & \hline Propriedades Valores \\ & \hline Função Principal: Superplastificante $3^{\text {a }}$ geração \\ & Base química: Policarboxilatos \\ & Aspecto: Liquido viscoso \\ & Cor: Bege \\ & Densidade: 1,067 a $1,107 \mathrm{~g} / \mathrm{cm}^{3} \\ &$ pH: 5 a 7 \\ & Sólidos: 28,5 a $31,5 \% \\ &$ Viscosidade: 95 a $160 \mathrm{cps} \\ &$\hline\end{aligned}

\subsection{Caracterização do compósito}

\subsubsection{Dosagem do compósito}

Na composição da argamassa, praticou-se uma variação da quantidade dos elementos a serem incorporados, sendo que o traço básico utilizado é o apresentado na Tabela 3.5, devido às características satisfatórias apresentadas em ensaios preliminares. A partir dos resultados obtidos por MONTEDOR (2004), com a utilização de fibras de PVA e VIDRO no compósito, procurou-se parametrizar algumas proporções dos elementos a fim de promover uma análise de desempenho desse novo compósito com os compósitos obtidos anteriormente, já que neste caso, as fibras utilizadas anteriormente foram substituídas por uma fibra polimérica de polipropileno, que apresenta custo menor em relação às outras.

Tabela 3.5: Traço de referência em massa

\begin{tabular}{cccc}
\hline Cimento & Areia & Látex & Água \\
\hline 1 & 0,3 & 0,3 & 0,1 \\
\hline
\end{tabular}


Da Tabela 3.5 pode-se observar que a proporção líquida incorporada à mistura foi de 0,4 vezes a quantidade de cimento, sendo desse total, $30 \%$ de látex e $10 \%$ de água. Considerando o teor de sólidos do látex, temos que, utilizou-se 15\% do teor de massa de sólidos para o látex estireno-butadieno e uma relação água/cimento final de 0,25.

Para que se possa promover uma identificação adequada dos resultados experimentais apresentados foi elaborada uma legenda descritiva dos materiais utilizados, a mesma está apresentada na Tabela 3.6.

Tabela 3.6: Legenda adotada.

\begin{tabular}{ll}
\hline Legenda & Descrição \\
\hline V + número & Consumo de Vermiculita (em \%) \\
PP + número & Taxa volumétrica de Fibra de Polipropilleno (em \%) \\
$\mathrm{L}+$ número & Taxa volumétrica de Látex (em \%) \\
\hline
\end{tabular}

Para desenvolvimento dos traços estudados, o cálculo do consumo de cimento partiu da equação 3.1, apresentada a seguir.

$$
\begin{gathered}
C=\frac{1000}{\frac{1}{\rho_{c}}+\frac{0,3}{\rho_{a}}+0,3+0,1} \\
\text { onde: } \begin{array}{l}
\rho_{c}=\rho_{\text {cimento }}=3,12 \mathrm{~g} / \mathrm{cm}^{3} \\
\rho_{a}=\rho_{\text {areia }}=2,63 \mathrm{~g} / \mathrm{cm}^{3}
\end{array}
\end{gathered}
$$

Neste ponto deve-se destacar que toda a areia utilizada foi passada na peneira com abertura de malha de $0,6 \mathrm{~mm}$.

Quando se incorpora vermiculita ao traço, é realizada uma alteração na equação 3.1 levando-se em conta sua massa específica, a fórmula utilizada nesta pesquisa no cálculo do consumo de cimento para todos os traços estudados é apresentada na equação 3.2.

$$
C=\frac{1000}{\frac{1}{\rho_{c}}+\frac{[0,3-(0,3 \cdot a)]}{\rho_{a}}+\frac{(0,3 \cdot a)}{\rho_{v}}+0,3+0,1}
$$




$$
\text { onde: } \begin{aligned}
& \rho_{v}=\rho_{\text {vermiculita }}=0,356 \mathrm{~g} / \mathrm{cm}^{3} \\
& a=\text { consumo de vermiculita (em \%) }
\end{aligned}
$$

Para melhor clareza da utilização da fórmula e da legenda adotada é apresentado um exemplo de cálculo para o traço V25PP2L30. Esta simbologia significa que do traço de referência mostrado acima, vai ser mantido constante o consumo de látex em 30\%, vai ser incorporada fibra de polipropileno na quantidade de $2 \%$ do volume da argamassa e, da quantidade de agregado miúdo, que está sendo incorporado a uma taxa de 0,3 da massa de cimento, 25\% será de vermiculita e 75\% será de areia fina. Sendo assim temos:

$a=0,25=25 \%$ de vermiculita.

Deixando a equação 3.2 da seguinte maneira:

$$
C=\frac{1000}{\frac{1}{\rho_{c}}+\frac{0,225}{\rho_{a}}+\frac{0,075}{\rho_{v}}+0,3+0,1}
$$

Resultando em um consumo de cimento $\mathrm{C}=984,78 \mathrm{~kg} / \mathrm{m}^{3}$.

A Tabela 3.7 mostra os consumos de cimento para todos os traços estudados.

Tabela 3.7: Consumos de cimento para os traços estudados.

\begin{tabular}{cc}
\hline Traço & Consumo de Cimento $\left(\mathrm{Kg} / \mathrm{m}^{3}\right)$ \\
\hline V0PP5L30 & 1198,20 \\
V5PP4,5L30 & 1150,23 \\
V10PP4L30 & 1103,86 \\
V15PP3,5L30 & 1061,10 \\
V20PP3L30 & 1021,51 \\
V25PP2,5L30 & 984,78 \\
\hline
\end{tabular}




\subsubsection{Variáveis}

As variáveis que estão sendo estudadas nesta pesquisa são a fibra de polipropileno e a vermiculita.

A proporção de látex, de acordo com os resultados obtidos por MONTEDOR (2004), foi mantida em 30\%, sendo este valor o que apresentava melhores resultados para a modificação da argamassa. O que verifica-se nessa pesquisa é a ação conjunta dessa quantidade de látex com as outras adições do compósito.

Efetivamente, as variações efetuadas na amostra foram de vermiculita e fibra de polipropileno, um resumo das incorporações está mostrado na Tabela 3.8.

Tabela 3.8: Variáveis estudadas.

\begin{tabular}{||c|c|c|c|c|c|c||}
\hline VARIÁVEIS & \multicolumn{7}{|c|}{ DOSAGEM (\%) } \\
\hline Vermiculita & 0 & 5 & 10 & 15 & 20 & 25 \\
\hline Fibras & 5 & 4,5 & 4 & 3,5 & 3,0 & 2,5 \\
\hline
\end{tabular}

A quantidade máxima de vermiculita incorporada à argamassa foi estipulada em $25 \%$ da massa de areia devido a dificuldade da moldagem do compósito e, também, devido a diminuição acentuada da resistência mecânica que o material apresentou. É importante ressaltar que, com a incorporação de grandes quantidades de vermiculita (20\% e 25\%), devido á grande capacidade de retenção de água da mesma, tornou-se necessário a utilização de superplastificante na razão de 1\%. Esta incorporação foi padronizada para todos os traços de maneira que se pudesse equalizar a análise para todos os ensaios.

Quanto à quantidade de látex, quando incorporado em quantidades maiores que $30 \%$ do volume, este proporciona uma queda significativa de resistência para a argamassa e, em quantidades muito menores que os $30 \%$, não apresentava modificações significativas nas propriedades do compósito. 
A dosagem de fibra foi sendo verificada de acordo com a facilidade de preparação e moldagem de cada traço levando-se em conta a quantidade de vermiculita já incorporada, ou seja, uma quantidade de vermiculita foi fixada e a quantidade de fibra foi variada até encontrar-se uma quantidade que não provocasse a perda de trabalhabilidade da argamassa.

\subsubsection{Caracterização do compósito}

Para a determinação das características mecânicas do compósito, foram realizados ensaios de compressão simples, tração por compressão diametral e módulo de elasticidade em corpos-de-prova.

No processo de caracterização do material foram moldados 11 corpos-de-prova cilíndricos de 50mm de diâmetro por $100 \mathrm{~mm}$ de altura, sendo que 4 deles eram utilizados para o ensaio de compressão uniaxial, 4 para o ensaio de tração por compressão diametral e 3 para o ensaio de compressão uniaxial para a obtenção do módulo de elasticidade. Considerando as seis dosagens estudadas, foram ensaiados 66 corpos-de-prova durante esse processo de caracterização do compósito.

Inicialmente, todo o processo de mistura dos materiais foi realizado manualmente, devido ao pequeno volume de material a ser moldado e também a falta de um equipamento de pequeno porte que fosse adequado. No decorrer da pesquisa, adquiriuse uma batedeira industrial que está sendo utilizada como argamassadeira do laboratório de estruturas. A seqüência apresentada na Figura 3.5 mostra o processo de amassamento manual e a seqüência da Figura 3.6 mostra o processo com a batedeira industrial. Nas fotos é apresentada a ordem seqüencial na qual os materiais vão sendo incorporados, primeiro ao cimento é misturada a areia e logo após a vermiculita, depois o látex é introduzido seguido da água de amassamento e, depois de praticamente umedecida toda a mistura ocorre a incorporação do superplastificante com um pouco de água e, somente no final do processo que a fibra é adicionada. 


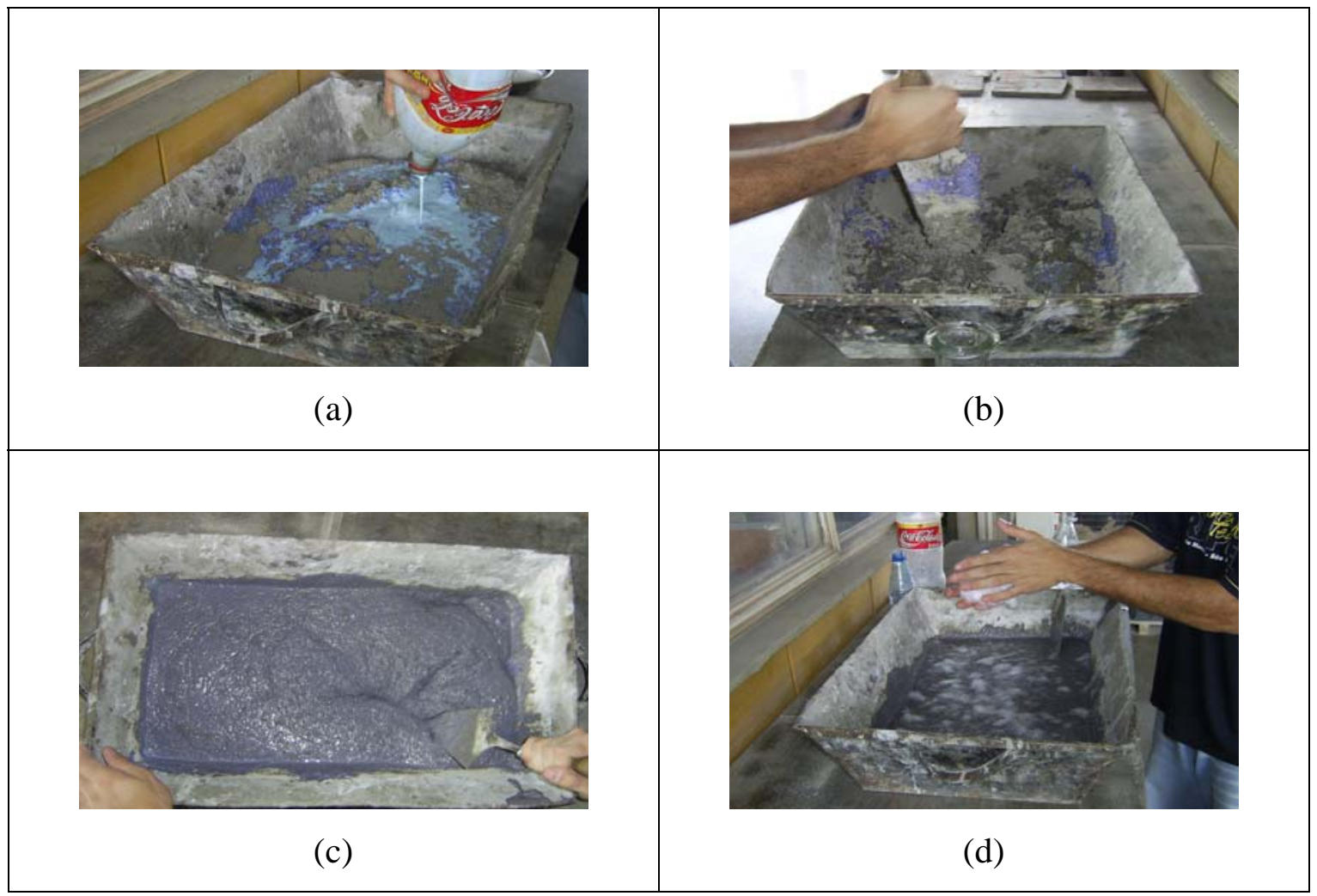

Figura 3.5: (a) Introdução de látex á mistura de cimento, areia e vermiculita; (b) consistência da mistura antes da introdução de água e superplastificante; (c) consistência melhorada após a introdução da água e superplastificante; (d) introdução da fibra de polipropileno.

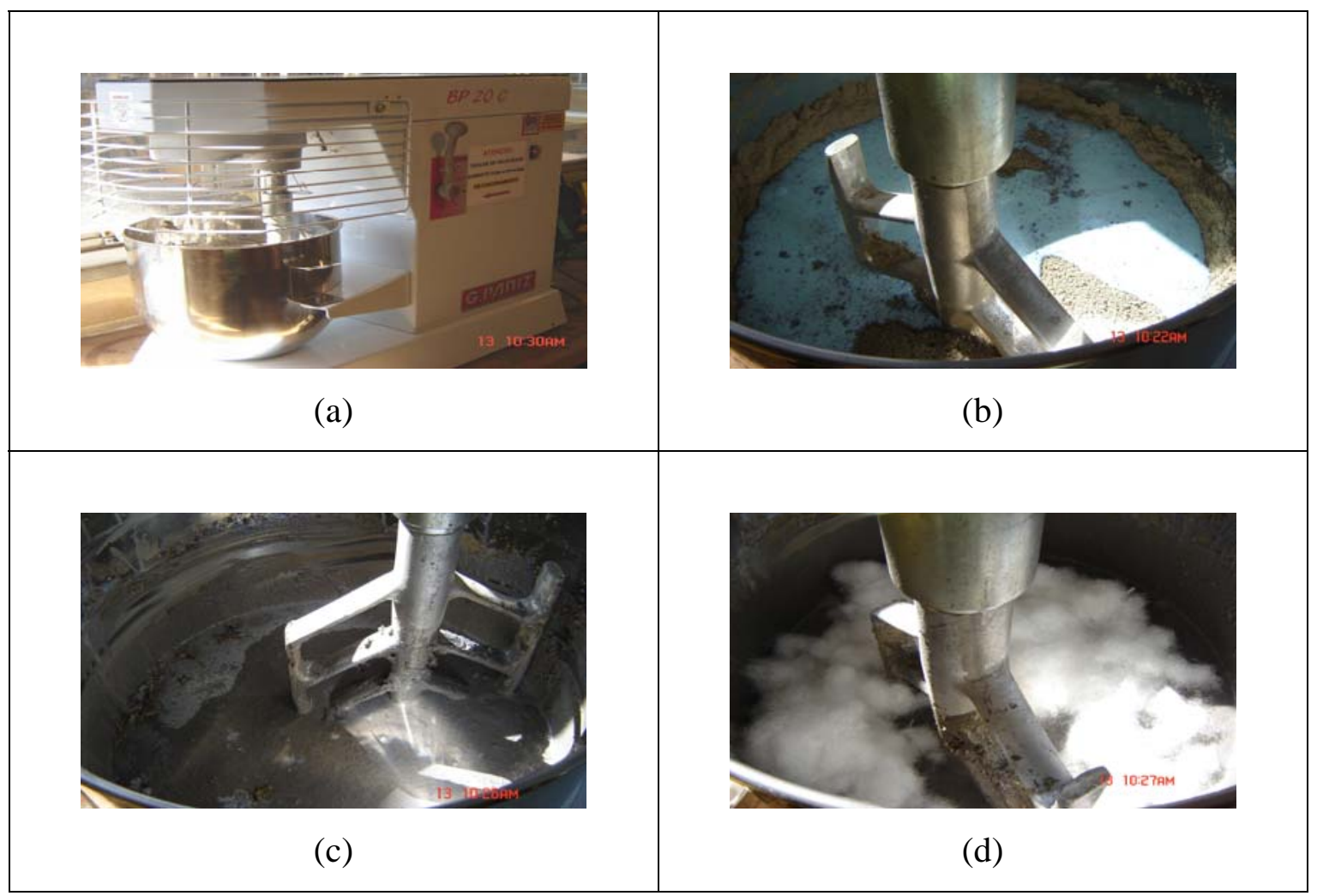

Figura 3.6: (a)Batedeira industrial utilizada na pesquisa; (b) introdução de látex á mistura de cimento, areia e vermiculita; (c) consistência melhorada após a introdução da água e superplastificante; (d) introdução da fibra de polipropileno. 
Tanto o material preparado manualmente quanto o preparado na batedeira industrial não apresentaram diferenças nas propriedades mecânicas observadas, a diferença foi observada no amassamento da argamassa, onde, a preparada na argamassadeira se apresentava mais fluída, fato este atribuído à uma maior energia de amassamento empregada e uma atuação mais efetiva do superplastificante na argamassa.

Na seqüência são apresentados os esquemas dos ensaios realizados em corpos-de-prova cilíndricos para obtenção das características mecânicas do compósito.

O processo de cura utilizada nesta pesquisa foi o de 48 horas com umidade de $100 \%$, sendo 24 horas com cura em forma mantendo a amostra sob espuma saturada de água e 24 horas em câmara úmida e, após, cura ao ar, com umidade de 50\% por pelo menos 7 dias.

Todos os ensaios desta pesquisa foram realizados para idades das amostras entre 14 e 21 dias.

Para o ensaio de compressão uniaxial, foram moldados 4 corpos-de-prova submetidos à compressão simples, onde foi verificada somente a carga de ruptura do elemento, obtendo-se assim, a tensão máxima do compósito para os diferentes traços. A Figura 3.7 mostra a moldagem dos corpos-de-prova e a Figura 3.8 o esquema do ensaio realizado.

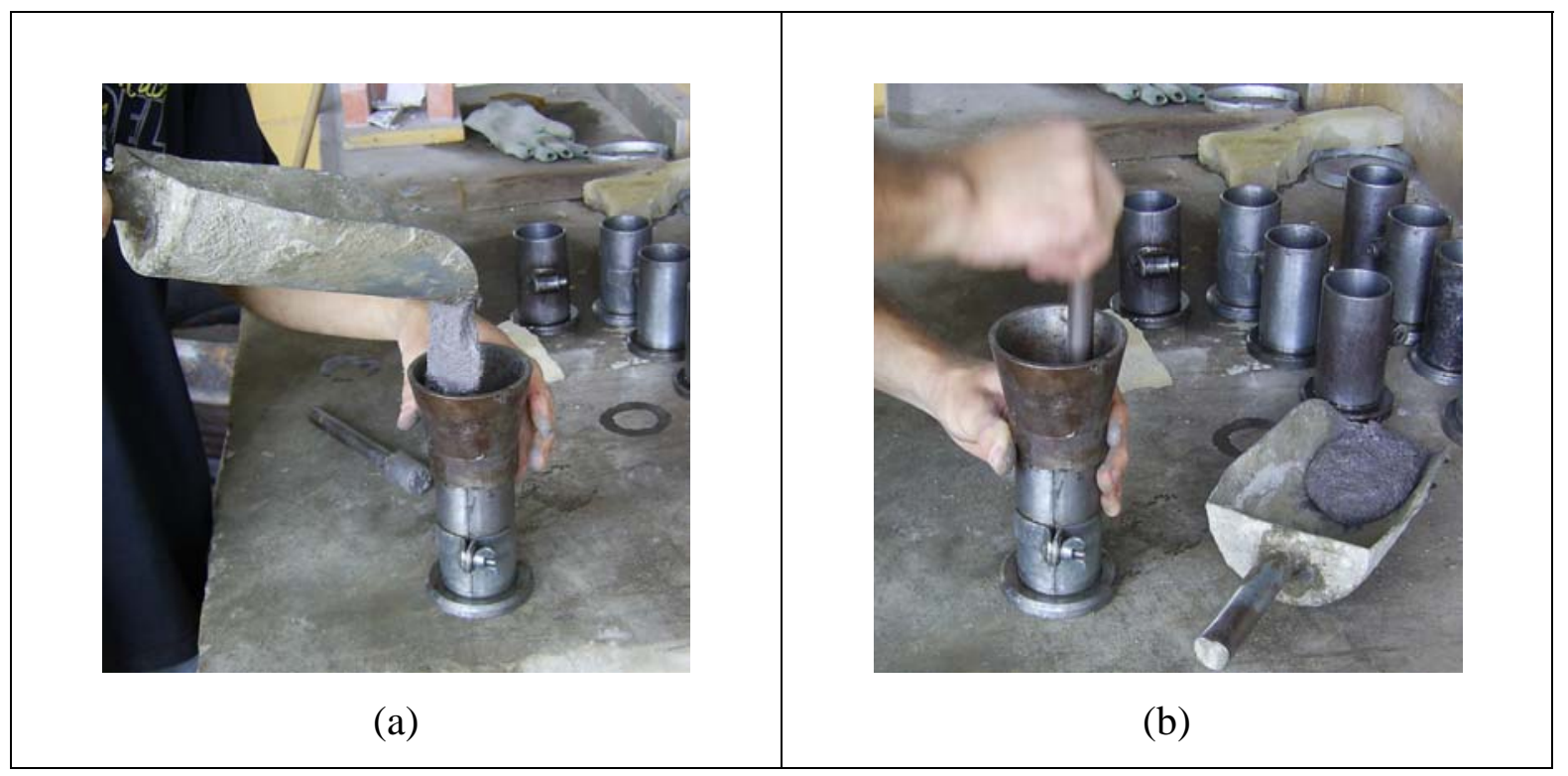

Figura 3.7: (a) Consistência da argamassa; (b) compactação da argamassa ao molde. 
O processo de moldagem dos corpos-de-prova cilíndricos foi executado segundo a NBR-7215/1996 - Resistência à compressão do cimento Portland.

Os valores das resistências e módulo de elasticidade de cada traço serão apresentados no capítulo de análise de resultados.

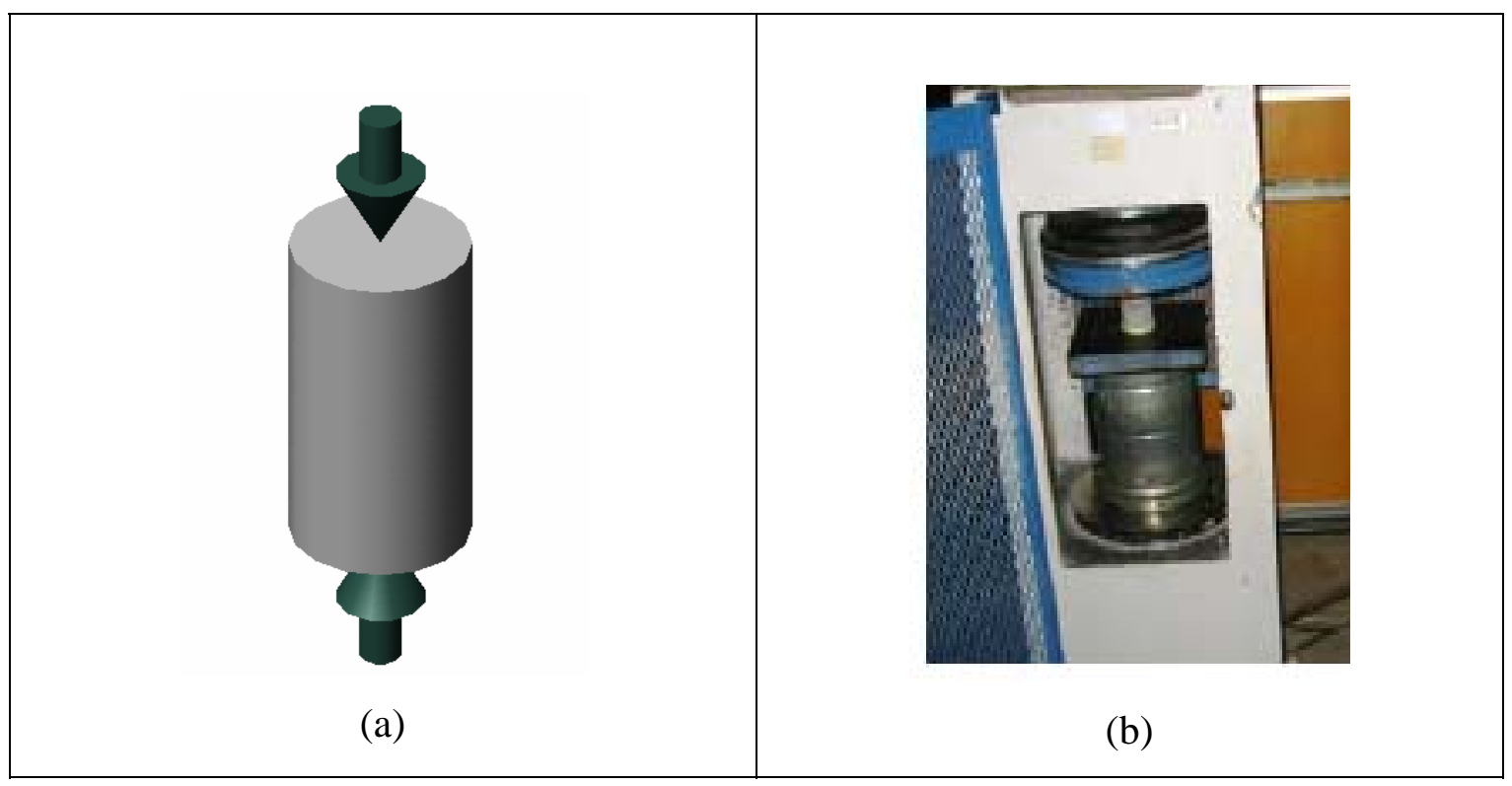

Figura 3.8: (a) e (b): Esquema do ensaio de compressão simples.

Para obtenção da resistência à tração do compósito, foi realizado o ensaio de compressão diametral, que fornece o valor dessa resistência de maneira indireta. Foram moldados também 4 corpos-de-prova que foram ensaiados em um dispositivo que aplica carga distribuída numa linha diametral do elemento. Para cada ensaio foi obtida a carga máxima de ruptura de cada corpo-de-prova, podendo-se calcular o valor da tensão máxima de ruptura do compósito para cada traço estudado. O esquema do ensaio está mostrado na Figura 3.9.

O cálculo da resistência à tração é realizado de forma indireta porque, a força de compressão aplicada no sentido do diâmetro do cilindro, gera uma tensão de tração transversal, uniforme ao longo do diâmetro e, cada elemento, submetido a um estado duplo de tensões, não romperá por compressão, mas por uma tração que pode ser calculada segundo a equação 3.3. 


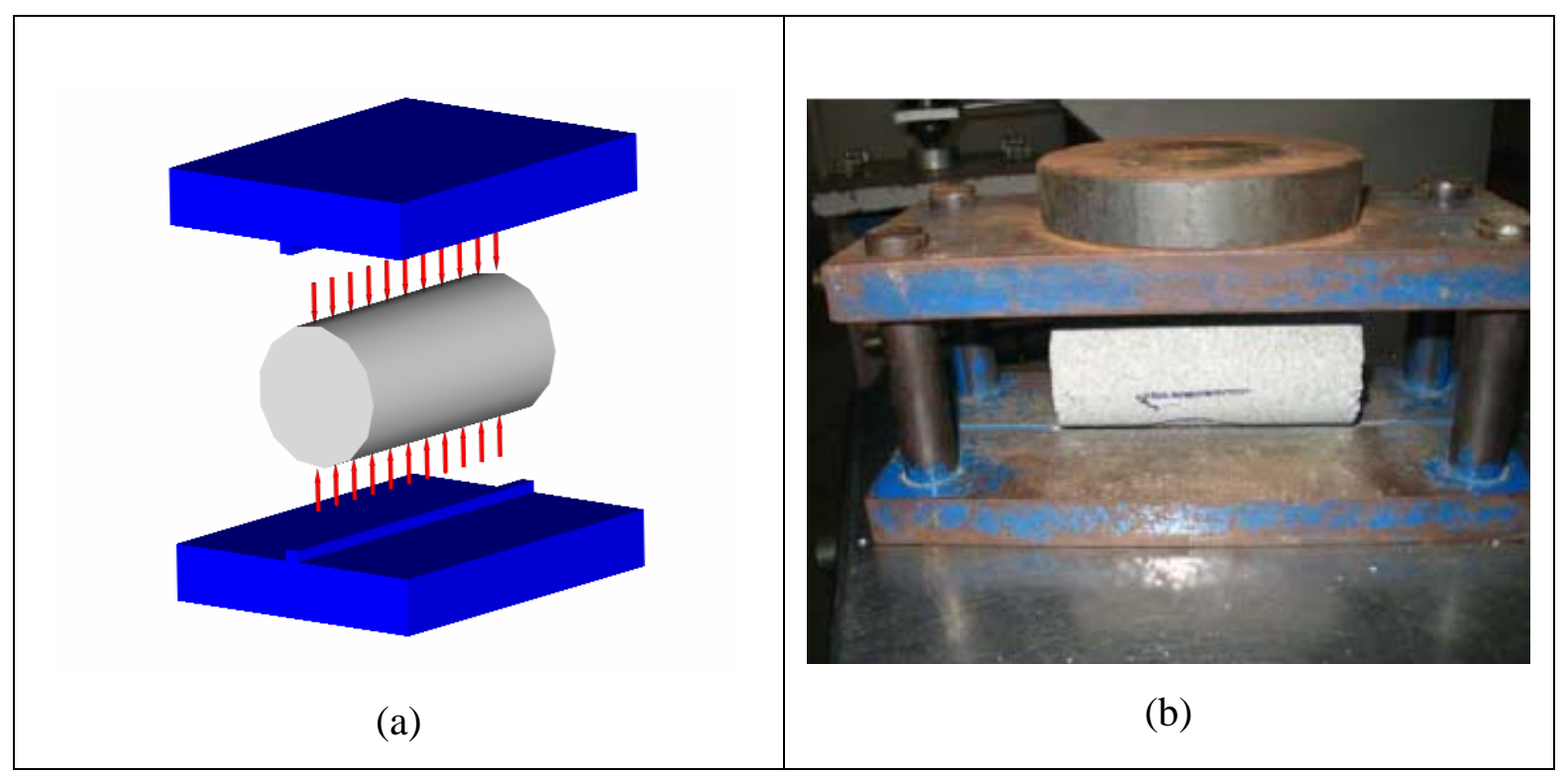

Figura 3.9 (a) e (b): Esquema do ensaio de tração por compressão diametral.

$$
f_{\mathrm{ct}, \mathrm{sp}}=\frac{2 \cdot \mathrm{F}}{\pi \cdot \mathrm{d} \cdot \mathrm{h}} \cdot 0,85
$$

Onde:

$\mathrm{f}_{\mathrm{ct}, \mathrm{sp}}$ : resistência a tração por compressão diametral;

F: força máxima aplicada;

d: diâmetro do corpo-de-prova;

h: altura do corpo-de-prova.

Para os ensaios de obtenção das resistências à compressão e tração do material, como foi necessário somente o conhecimento das cargas máximas na ruptura dos corpos-deprova, os ensaios foram realizados na máquina da marca ELE do laboratório de Estruturas. Esta máquina aplica carga apenas com o controle da força no elemento. A máquina utilizada nos ensaios pode ser vista na Figura 3.10. Os ensaios de compressão foram realizados segundo a NBR5739/1994 e, os ensaios de tração por compressão diametral segundo a NBR7222/1994. 


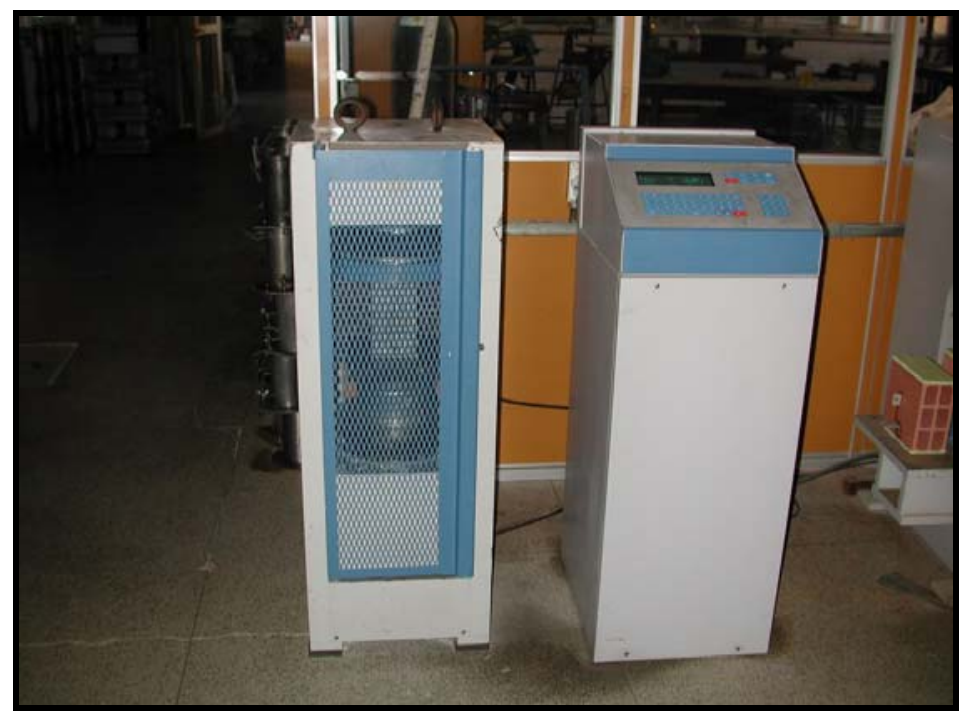

Figura 3.10: Máquina de ensaios marca ELE.

Na obtenção do módulo de elasticidade, 3 corpos-de-prova cilíndricos foram ensaiados com transdutores de deslocamento posicionados em lados opostos, podendo-se assim, obter a curva tensão x deformação para o cálculo do módulo de elasticidade tangente e secante para cada traço analisado. Cada transdutor possui haste de $50 \mathrm{~mm}$ sendo posicionado a uma distância de $25 \mathrm{~mm}$ da extremidade do corpo-de-prova. Os ensaios foram realizados na máquina de ensaios Versatester 30M do laboratório de Estruturas e com o auxílio de um equipamento capaz de realizar a leitura dos transdutores. O esquema do ensaio está mostrado na Figura 3.11.

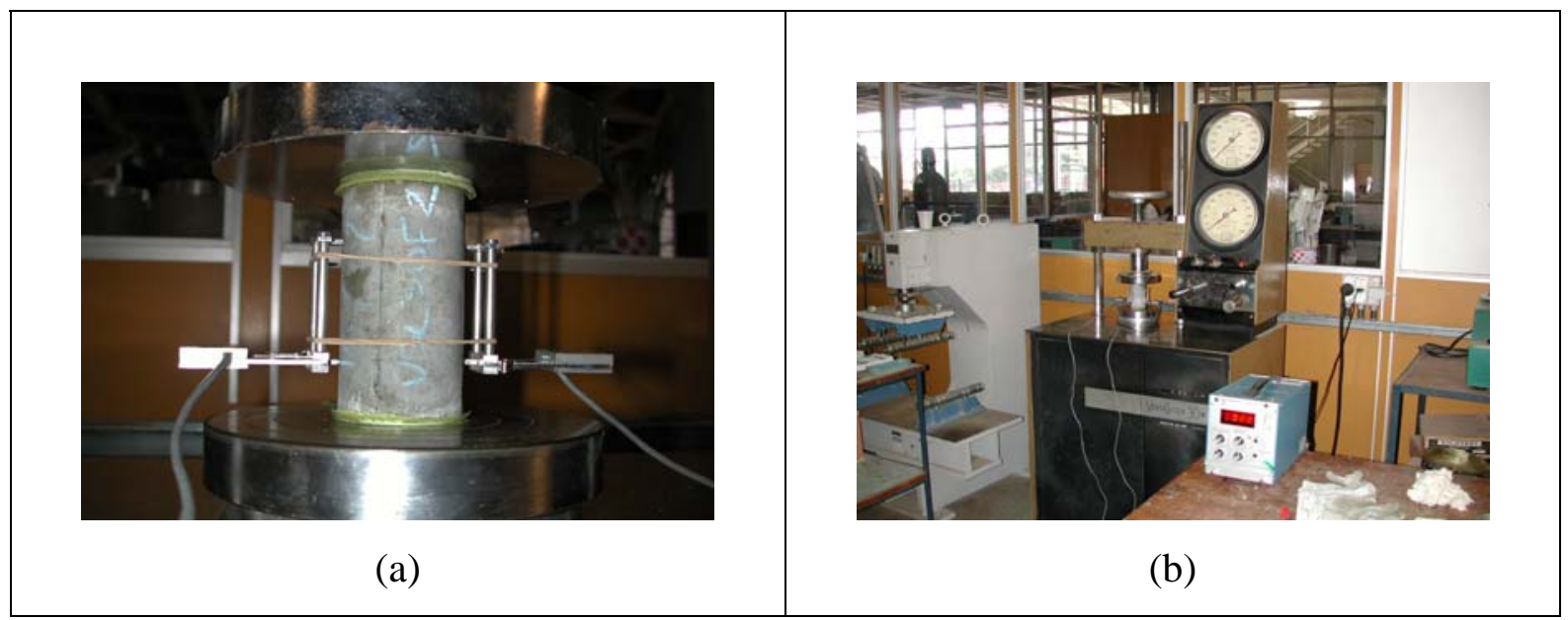

Figura 3.11: (a) Corpo-de-prova com transdutor de deslocamento; (b) esquema completo do ensaio de módulo de elasticidade. 
As leituras dos deslocamentos foi realizada a cada $2,5 \mathrm{kN}$ e os valores observados com a ajuda do equipamento foram anotados em uma planilha manual, que depois foi passada para uma planilha eletrônica. Estes valores foram lançados em gráficos, como mostrado na Figura 3.12, possibilitando assim o cálculo dos valores do módulo de elasticidade tangente e o secante.

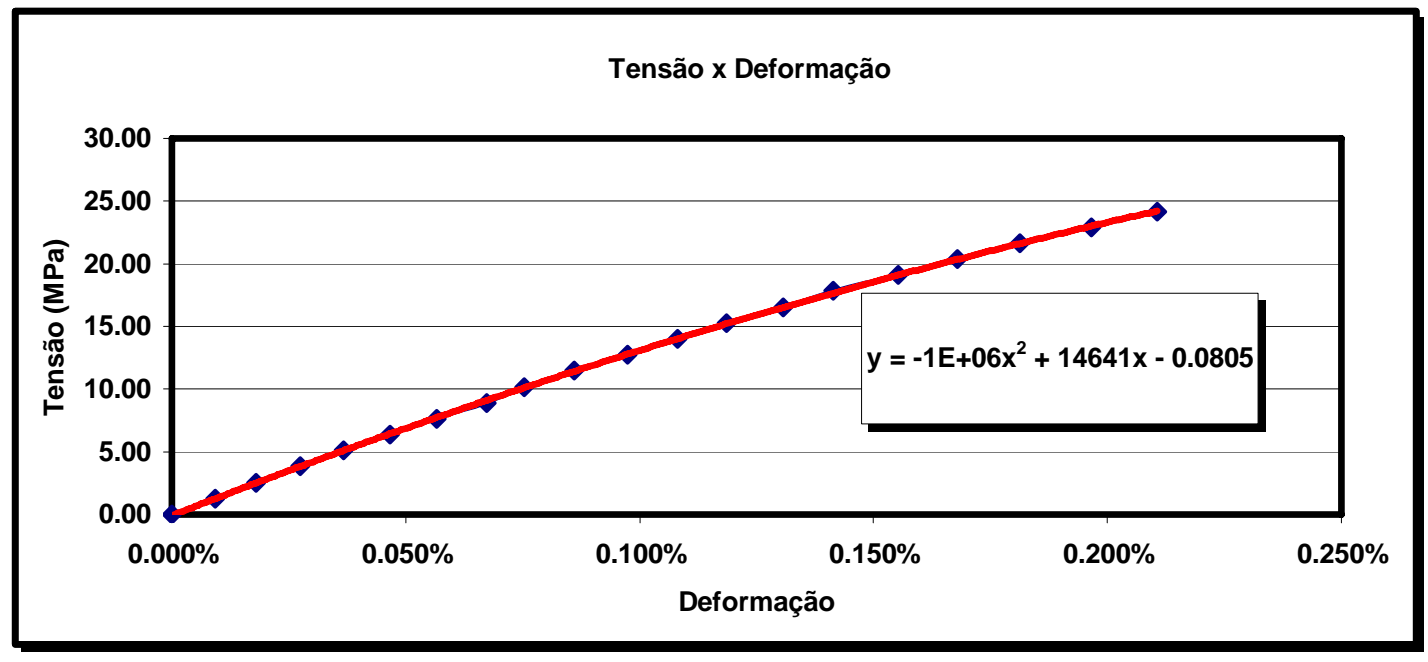

Figura 3.12: Gráfico para determinação do módulo de elasticidade.

A Figura 3.12 ilustra um exemplo de um gráfico para um traço do compósito. Para obtenção do valor do módulo de elasticidade tangente foi tomado o valor do coeficiente variável $\mathbf{x}^{1}$ da equação do segundo grau apresentada na Figura acima, ou seja, o valor do módulo de elasticidade tangente para este traço é $14641 \mathrm{MPa}$. O valor do módulo de elaticidade secante foi calculado pela razão entre um valor de resistência da ordem de $50 \%$ da tensão de ruptura do material sobre um ponto de deformação coincidente nas duas curvas, tanto a experimental quanto a curva de regressão.

Seguindo o mesmo critério adotado por MONTEDOR (2004), a depuração dos resultados das características mecânicas do material, foi realizada pelo critério de Chauvenet, no qual, para uma série de medidas, a probabilidade de ocorrência de um desvio de valor “ $x$ ” é menor que $1 / 2 n$, onde $n$ corresponde ao número de medidas (TAKEYA, 2001). 



\section{Programa Experimental}

\subsection{Preliminares}

Este capítulo descreve o programa experimental realizado especificamente com as almofadas do compósito, trazendo suas características e suas propriedades básicas. São descritos todos os ensaios realizados com almofadas de argamassa e os parâmetros que foram estudados, verificando-se as características do elemento de apoio de argamassa. São descritos os ensaios com carga distribuída sobre a almofada, ensaios com aplicação de força concentrada, simulações de ligação utilizando a almofada como elemento de apoio e a ensaios de rotação em almofadas do compósito, que visam medir a capacidade de rotação que essas almofadas podem ser submetidas. Também no final desse capítulo são descritos alguns ensaios que foram realizados com caráter exploratório para o material, sendo apresentados como parâmetros qualitativos do compósito.

\subsection{Ensaios de força distribuída}

\subsubsection{Carregamento Monotônico}

O ensaio de carregamento monotônico foi realizado nas almofadas do compósito para determinar a rigidez de placa, ou seja, uma medida da capacidade de deformação dessas almofadas. Esta relação foi chamada de rigidez neste trabalho, e não módulo de deformação de placa, devido a forma de placa do elemento e sua pequena espessura, que quando verificada sua deformação, esta possui valores maiores que os corpos-de-prova cilíndricos estudados, gerando uma redução significativa nos valores obtidos para a rigidez das placas, em relação ao módulo de deformação dos corpos-de-prova cilíndricos. 
Para este ensaio foram moldadas duas placas de $15 \mathrm{~cm} \times 15 \mathrm{~cm}$ de lado com espessura de $10 \mathrm{~mm}$, para cinco traços diferentes do compósito, que foram submetidas à compressão simples. Os dados foram salvos e uma curva força deslocamento foi traçada para cada almofada, podendo-se a relação para cada um dos cinco traços estudados. Para as almofadas, a cura e a idade de ruptura adotada foram as mesmas utilizadas para o caso dos corpos-de-prova cilíndricos. Os cinco traços estudados nesta fase da pesquisa estão apresentados na Tabela 4.1.

Tabela 4.1: Traços estudados no ensaio de carregamento monotônico.

\begin{tabular}{cc}
\hline Traços Estudados & Descrição \\
\hline V5PP4,5L30 & $5 \%$ de vermiculita e 4,5\% de fibra de polipropileno \\
V10PP4L30 & $10 \%$ de vermiculita e $4,0 \%$ de fibra de polipropileno \\
V15PP3,5L30 & $15 \%$ de vermiculita e $3,5 \%$ de fibra de polipropileno \\
V20PP3L30 & $20 \%$ de vermiculita e $3,0 \%$ de fibra de polipropileno \\
V25PP2,5L30 & $25 \%$ de vermiculita e $2,5 \%$ de fibra de polipropileno \\
\hline
\end{tabular}

As almofadas foram ensaiadas na máquina marca INSTRON, modelo 8506, a uma velocidade de $0,01 \mathrm{~mm} / \mathrm{s}$ e levadas até a carga de $2000 \mathrm{kN}$. A Figura 4.1 mostra o esquema do ensaio e a máquina de ensaios do laboratório de Estruturas. O sistema de aquisição dos dados utilizados neste ensaio foi o modelo System 5000 da Measurements Group.

Com os resultados foram traçadas as curvas força $\mathrm{x}$ deslocamento para os elementos e, após a fase de acomodação das deformações inicias, foi traçada uma reta sobre estas curvas (Figura 4.2), calculando-se a rigidez de cada uma das amostras como sendo o coeficiente angular de cada reta. A rigidez admitida para cada traço foi a média destes dois valores. Como a unidade de referência para estes valores é o Megapascal (MPa), depois de realizado o cálculo deste coeficiente angular, as unidades foram devidamente transformadas para este sistema. 


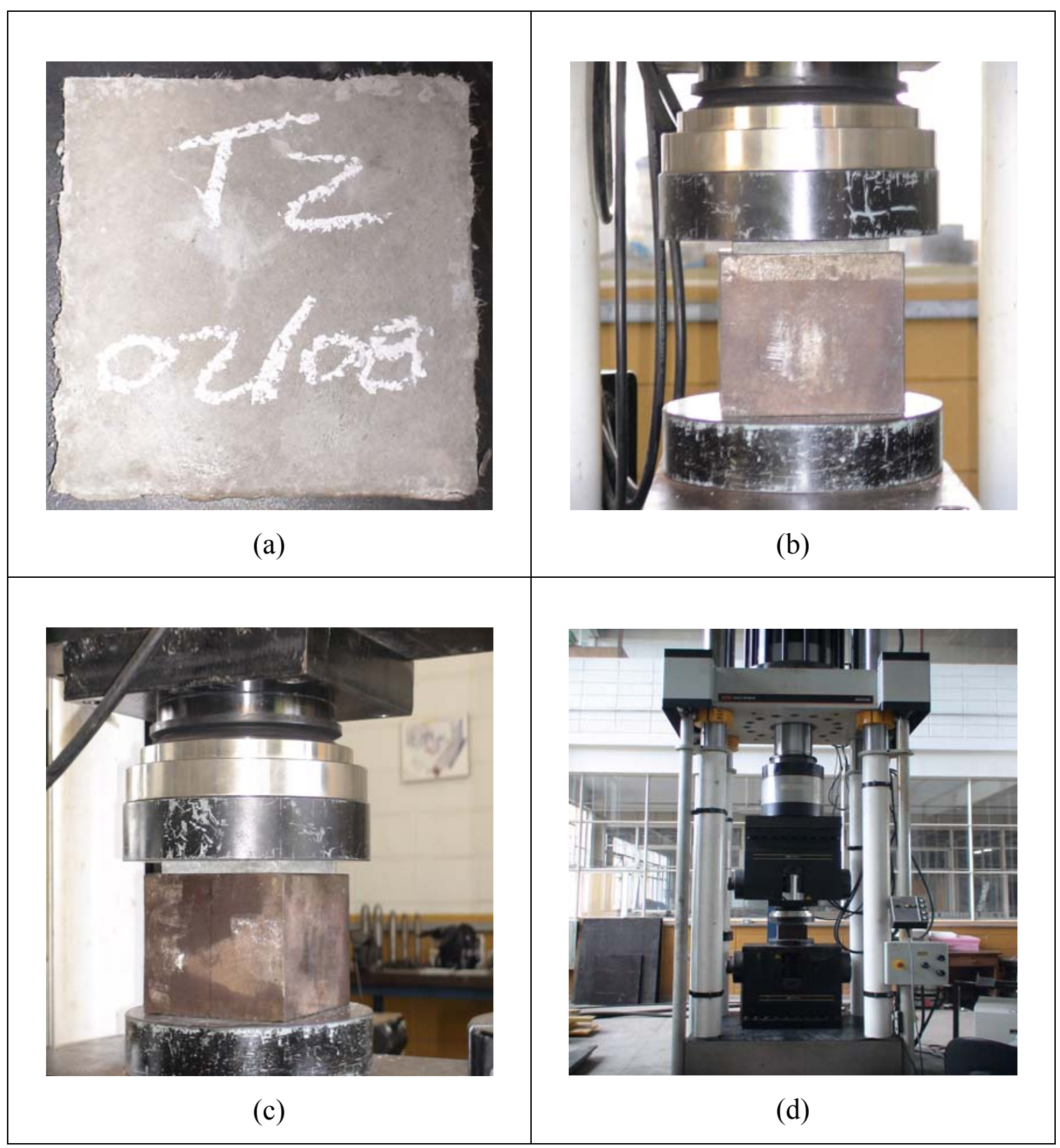

Figura 4.1: (a) Almofada do compósito; (b) e (c) Esquemas do ensaio de carregamento monotônico; (d) Máquina de ensaios. 


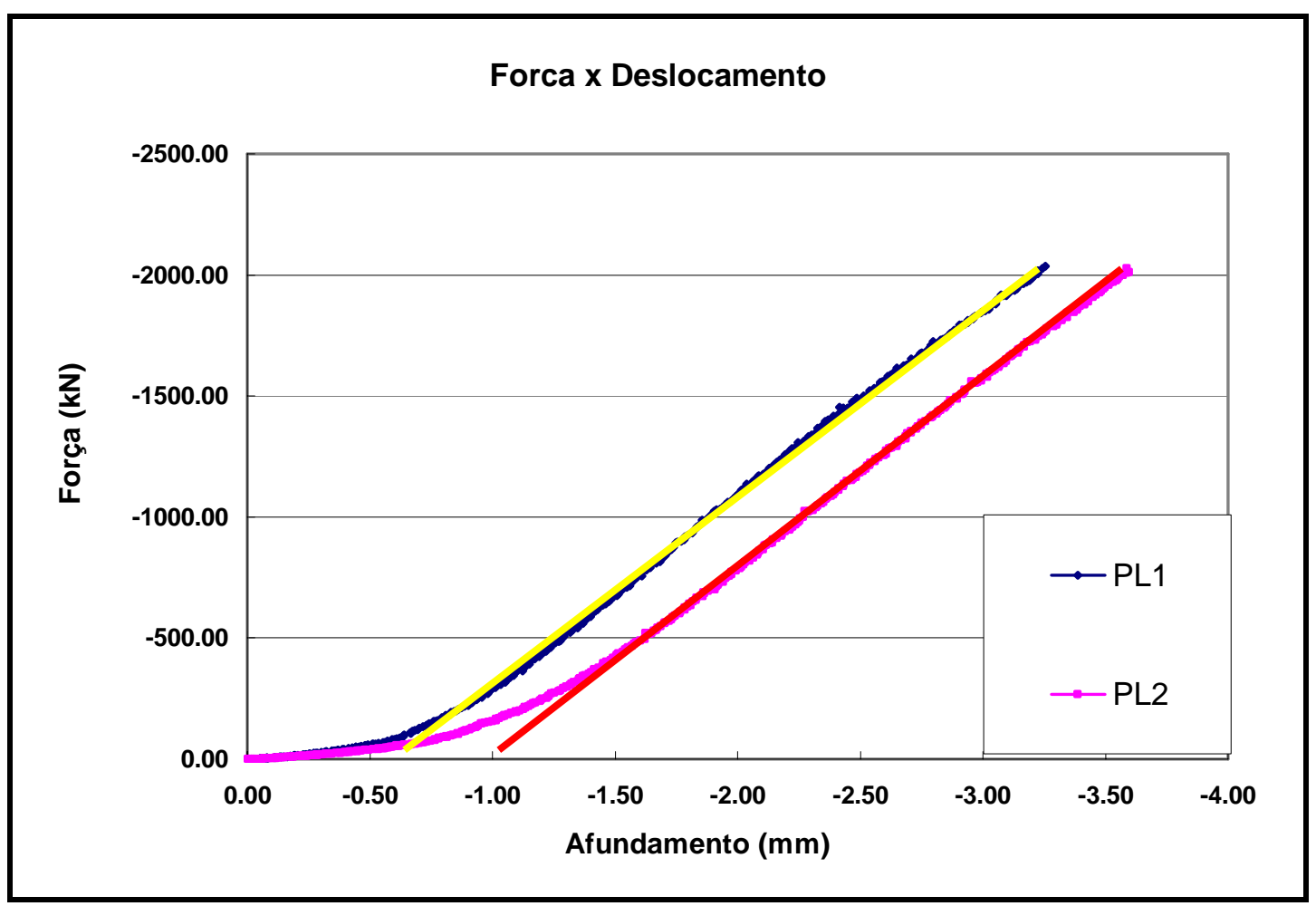

Figura 4.2: Gráfico força $x$ deslocamento para duas amostras de almofada.

A Equação 4.1 representa a maneira de calcular as rigidezes das placas de maneira a torná-la mais compreensível.

$$
\mathrm{R}=\frac{\sigma}{\frac{\Delta h}{h}}
$$

Onde:

$\mathrm{R}=$ rigidez da placa;

$\sigma=$ tensão aplicada na placa;

$\Delta h=$ variação da espessura da placa;

$h=$ espessura da placa.

\subsubsection{Carregamento Cíclico}

Em complementação ao ensaio de carregamento monotônico, onde aplicou-se carga de compressão até o limite máximo do equipamento e verificou-se a rigidez da almofada, 
realizou-se o ensaio de carregamento cíclico, no qual procurou-se obter uma visualização da evolução da rigidez com um regime de carga repetitivas.

O esquema básico do ensaio cíclico foi o mesmo utilizado para o ensaio monotônico, sendo que, as almofadas utilizadas neste ensaio possuíam as mesmas dimensões das do ensaio anterior, ou seja, $15 \mathrm{~cm} \times 15 \mathrm{~cm}$ de base e espessura de $10 \mathrm{~mm}$. A diferença ficou por conta dos carregamentos que foram repetidos ciclicamente, até cargas que promovessem pressões de contato da mesma ordem de grandeza do que se poderia verificar em situações práticas de utilização das almofadas de apoio. Também a quantidade de traços estudados foi reduzida a três do material, o V5PP4,5L30, V10F4L30 e o V15F3,5L30.

A escolha desses traços se deu em função das resistências dos corpos-de-prova cilíndricos e das rigidezes apresentadas nos ensaios monotônicos, acreditando-se que estes seriam os mais adequados para uma utilização prática, gerando uma necessidade de estudos mais concentrados sobre os mesmos.

Para a aquisição dos dados do ensaio, utilizou-se o sistema de aquisição para ensaios dinâmicos System 6000 da Measurements Group (Figura 4.3).

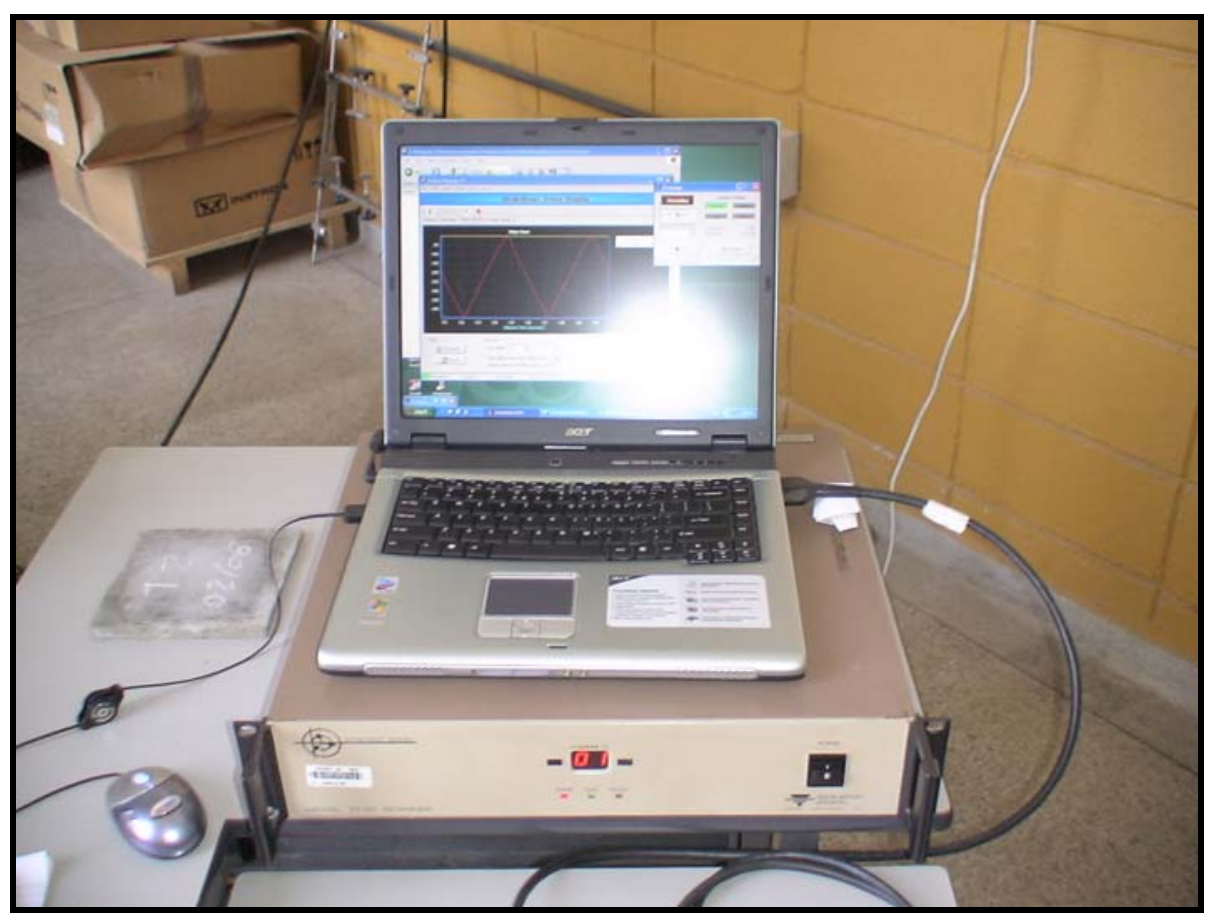

Figura 4.3: Sistema de aquisição de dados System 6000. 
As tensões adotadas para este ensaio foram de $2,5 \mathrm{MPa}, 5,0 \mathrm{MPa}, 10,0 \mathrm{MPa}$ e $20,0 \mathrm{MPa}$. Com a adoção destes valores de tensões, as forças nas respectivas fases dos ensaios foram de aproximadamente $55 \mathrm{kN}, 112 \mathrm{kN}, 225 \mathrm{kN}$ e $450 \mathrm{kN}$. Na primeira fase dos ensaios, para cada valor de tensão, foram realizados ciclos de 50 repetições (figuras 4.4 e 4.5) para cada carregamento correspondente. As cargas foram aplicadas até os valores limites e levados a um valor próximo de zero, este não podendo ser atingido por limitações da máquina de ensaio.

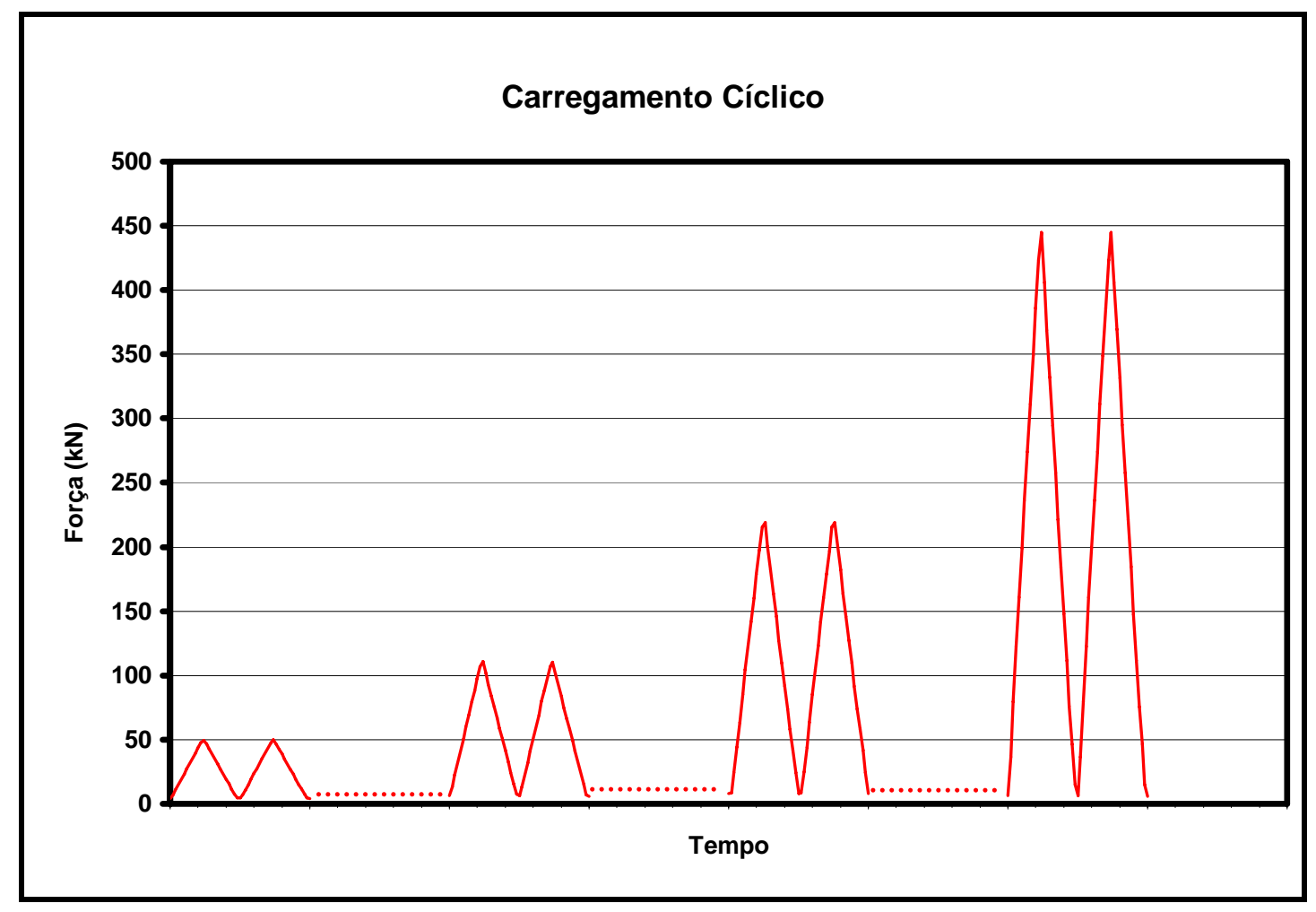

Figura 4.4: Ciclos de carregamento da almofada.

Como pode ser observado na Figura 4.4, para cada passo de carga foram aplicados 50 ciclos de carregamento. Como os dados se apresentaram em uma nuvem muito densa de pontos e de difícil visualização do comportamento da rigidez ao longo do tempo, optouse por analisar os resultados a partir dos dados do primeiro e do último ciclo para cada série do carregamento. Um exemplo dessa nova configuração dos dados pode ser observado na Figura 4.6. 


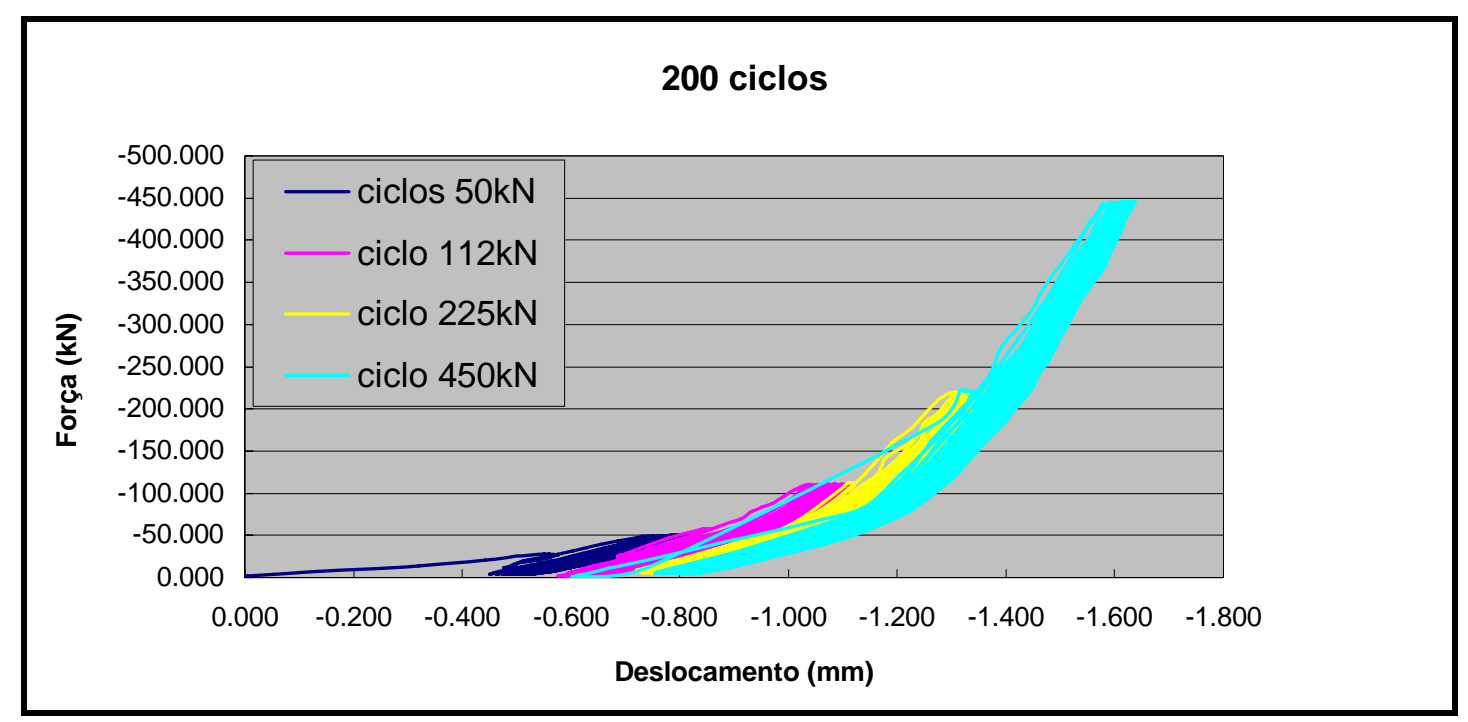

Figura 4.5: Carregamento cíclico na almofada.

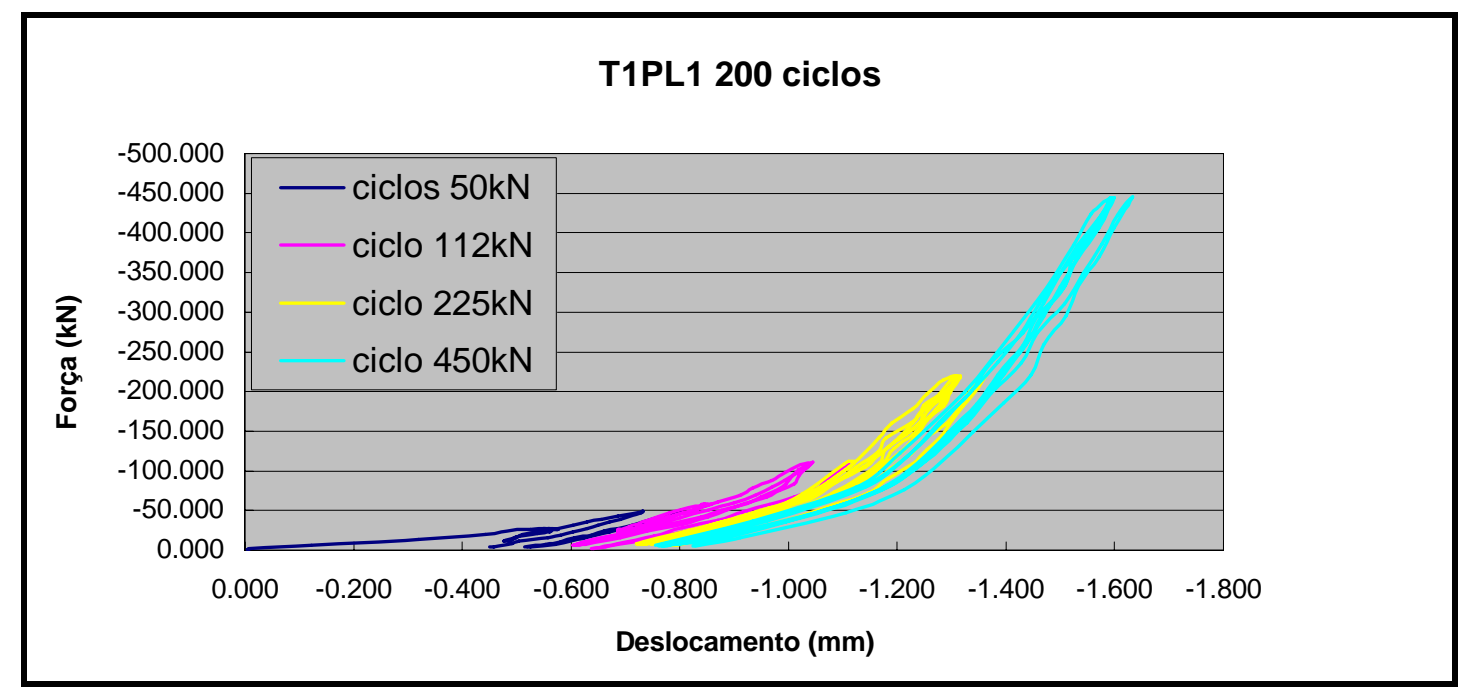

Figura 4.6: Carregamento cíclico na almofada após a retirada de pontos intermediários.

$\mathrm{Na}$ segunda fase do estudo com carregamentos cíclicos foram realizados ensaios com a mesma configuração dos ciclos anteriores, mas nesta nova fase optou-se por aplicar na almofada um número maior de ciclos para cada incremento de carga. Estes ciclos passaram então de 50 para 300 para cada passo de carga (Figura 4.7). Como se pode observar, a dificuldade em ler os dados da evolução das rigidezes se apresentou maior nesse caso, portanto adotou-se o mesmo procedimento de análise da primeira fase dos ensaios, gerando-se curvas apenas do primeiro e do último ciclo de cada incremento de carga (Figura 4.8). 


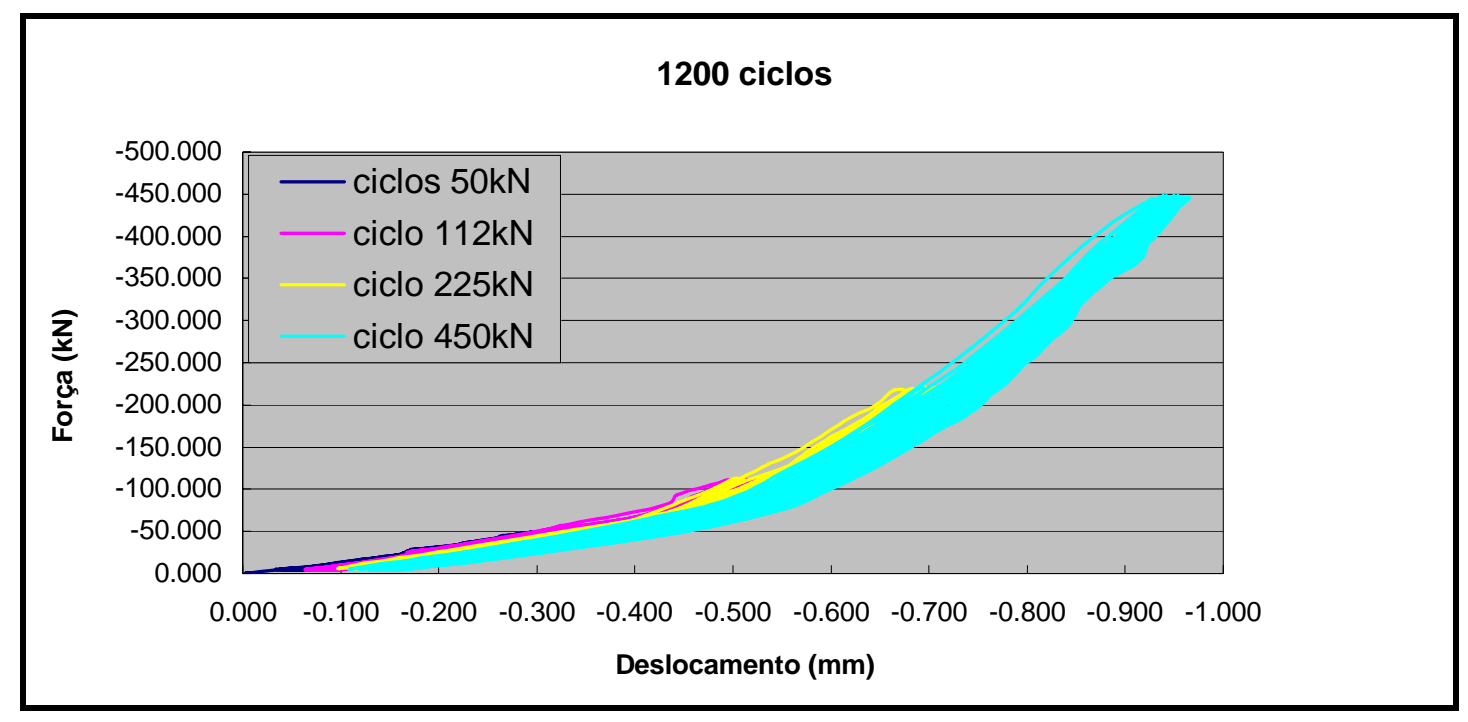

Figura 4.7: Exemplo de ensaio de almofada com 1200 ciclos de carregamento.

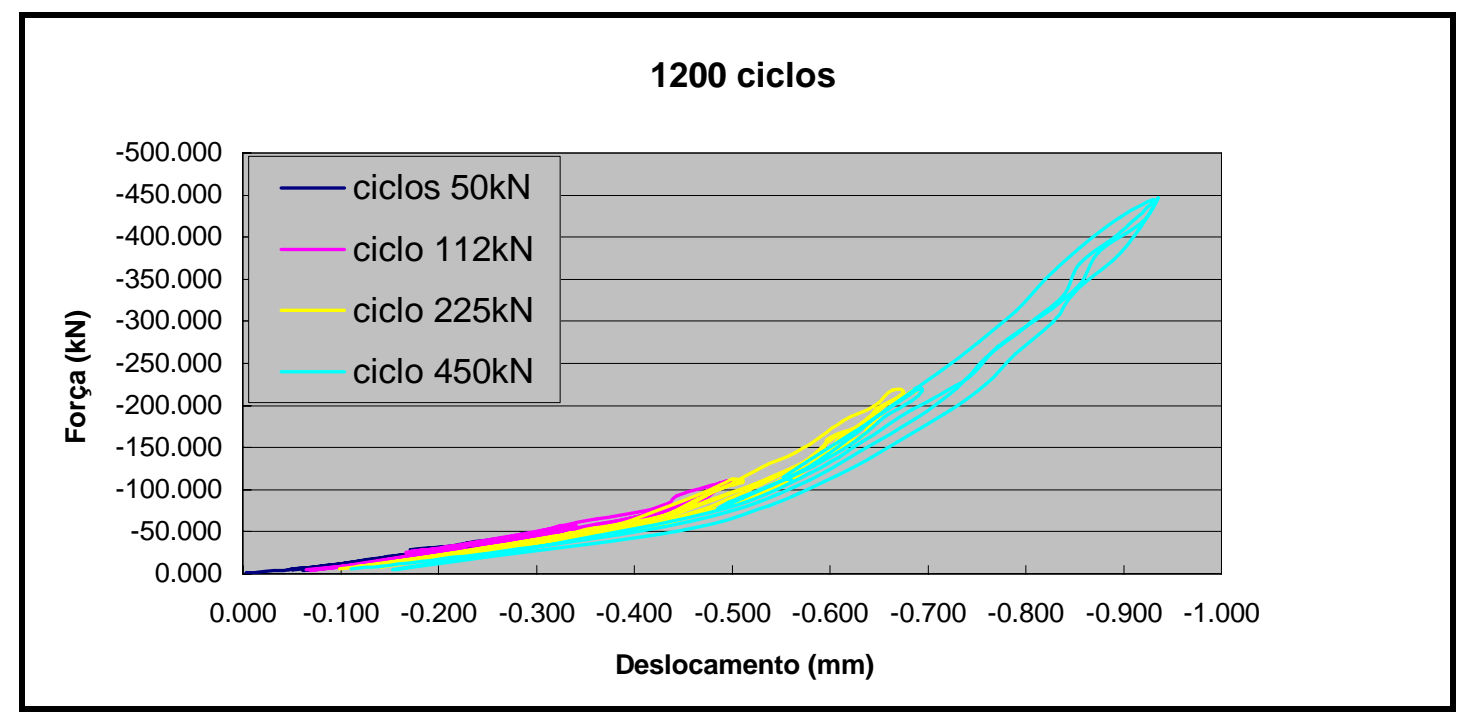

Figura 4.8: Exemplo de ensaio de almofada com 1200 ciclos após retirada de pontos intermediários.

\subsection{Ensaios de força concentrada}

Este ensaio de força concentrada derivou dos ensaios de força concentrada realizados por MONTEDOR (2004) visando-se medir a capacidade de acomodação de cargas pontuais de tiras de almofada do compósito, ou afundamento, parametrizando-se assim, a quantidade de vermiculita como o objeto principal de observação.

A vermiculita foi o foco deste ensaio porque, a partir de uma determinada quantidade incorporada na argamassa, as características da almofada são alteradas de maneira 
prejudicial, aumentando-se muito a capacidade de afundamento desta, em detrimento de sua resistência e rigidez. Também porque, na pesquisa de MONTEDOR (2004), foi realizado um ensaio onde se tentou descrever uma quantidade ideal para a incorporação desta ao compósito.

Os resultados apresentados pelo pesquisador mostraram que, quanto maior essa incorporação, isso acarreta numa maior deformabilidade da almofada, com reduzida resistência, portanto, não sendo indicada sua utilização.

Este ensaio consistiu em cortar as almofadas de $15 \mathrm{~cm} \times 15 \mathrm{~cm}$ em fatias de $2,5 \mathrm{~cm} \times$ $15 \mathrm{~cm}$, nas quais seriam aplicadas duas cargas pontuais em dois pontos localizados a $3,75 \mathrm{~cm}$ da borda da fatia. Nesta pesquisa, optou-se por estudar com mais ênfase, somente a espessura de $10 \mathrm{~mm}$, por esta apresentar melhores resultados de rigidez de placa quando comparada às almofadas de $20 \mathrm{~mm}$ de espessura, de acordo com a pesquisa anterior. Neste momento cabe ressaltar que a rigidez de placa é a relação entre a tensão aplicada e a deformação sofrida pela almofada, em ensaios de carga uniforme, que será apresentado adiante. Um esquema do ensaio é apresentado na Figura 4.9.

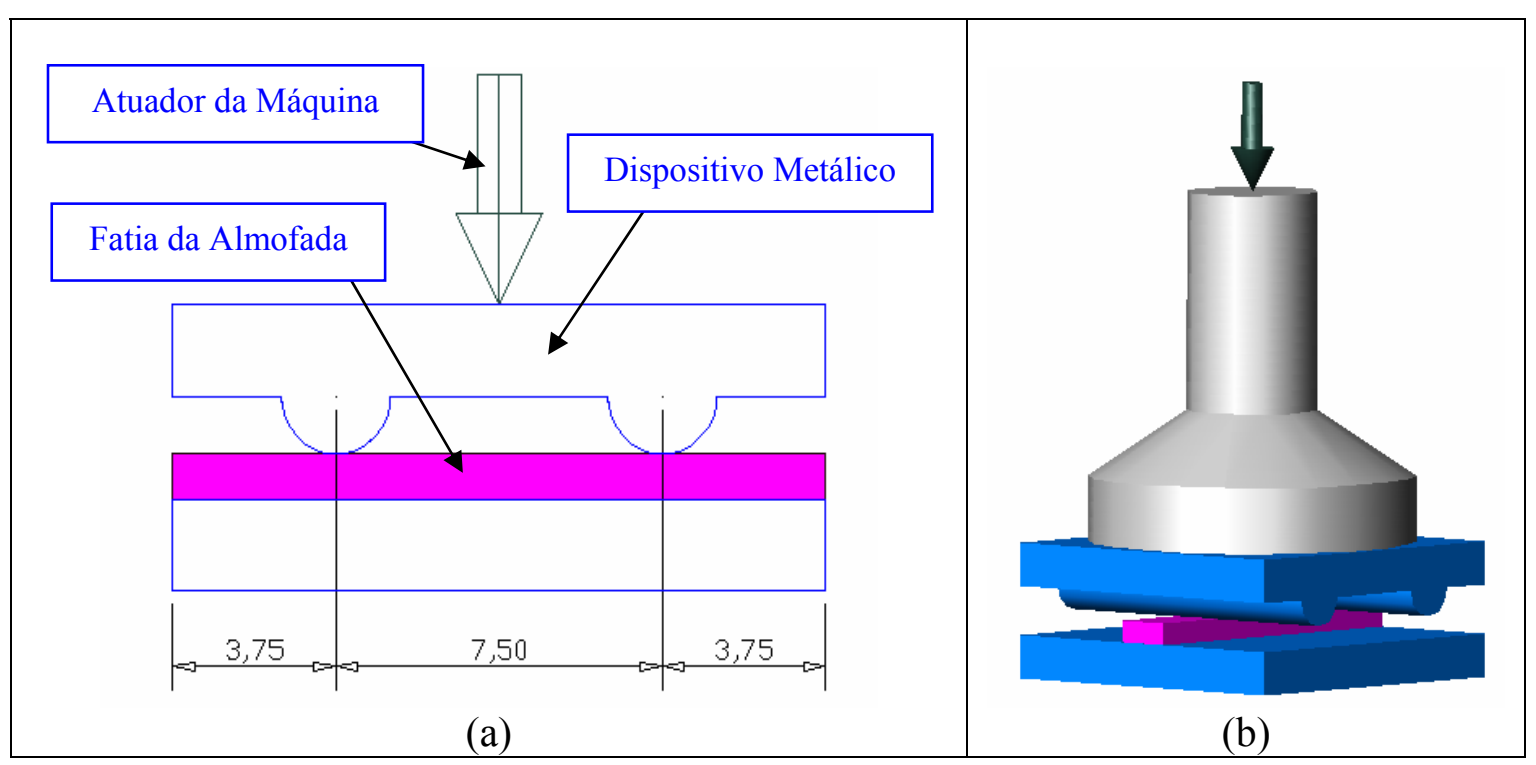

Figura 4.9: (a) Esquema frontal ensaio de carga concentrada (medidas em $\mathrm{cm}$ ); (b) Esquema tridimensional do ensaio.

O ensaio consistiu na aplicação de carga com controle de deformação da máquina a uma taxa de $0,01 \mathrm{~mm} / \mathrm{s}$. Os dados foram gravados num sistema de aquisição de dados do 
laboratório de mecânica das rochas do departamento de Geotecnia da Escola de Engenharia de São Carlos a uma velocidade de três pontos por segundo. A máquina utilizada para a realização deste ensaio é a MTS modelo 815 - Rock Mechanics Test System - capacidade 2700 kN. Na Figura 4.10 está apresentada a máquina utilizada no ensaio.

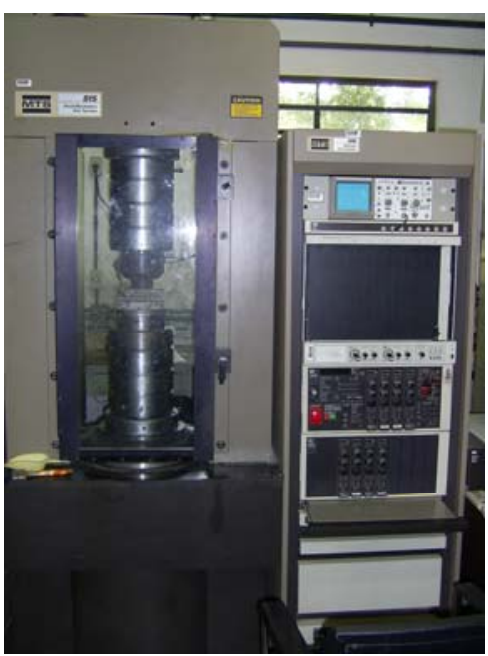

(a)

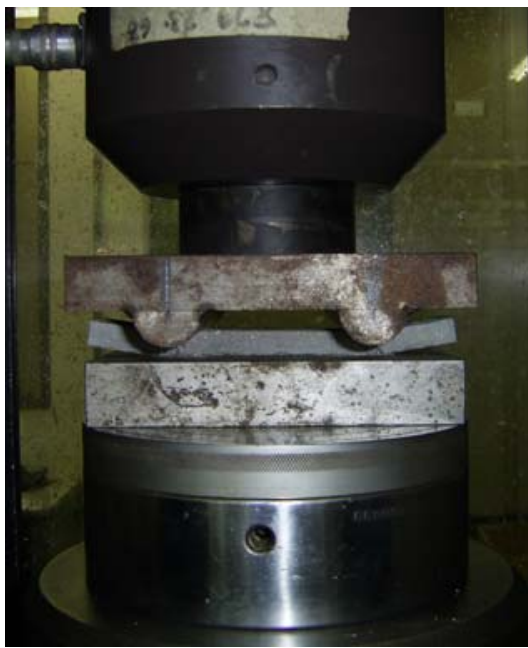

(b)

Figura 4.10: (a) Máquina MTS utilizada nos ensaios de carga localizada; (b) Vista ampliada do ensaio de afundamento.

Foram retiradas amostras para seis traços diferentes do material, começando com teor de $0 \%$ de vermiculita no compósito, até a quantidade de $25 \%$ de vermiculita na mistura. Todos os traços estudados estão na Tabela 4.2

Para cada traço, 10 amostras de tiras de almofadas foram ensaiadas e pode-se obter a curva força $\mathrm{x}$ deslocamento para cada amostra. A partir dessas curvas, verificou-se o comportamento médio dessas amostras, traçando-se a curva média, a partir dos resultados que se apresentaram com maior consistência, eliminando-se os resultados que apresentaram as maiores diferenças. Um exemplo dos gráficos obtidos para um traço é apresentado na Figura 4.11. 
Tabela 4.2: Traços estudados no ensaio de carga localizada.

\begin{tabular}{cc}
\hline Traços Estudados & Descrição \\
\hline V0PP5L30 & $0 \%$ de vermiculita e $5,0 \%$ de fibra de polipropileno \\
V5PP4,5L30 & $5 \%$ de vermiculita e $4,5 \%$ de fibra de polipropileno \\
V10PP4L30 & $10 \%$ de vermiculita e $4,0 \%$ de fibra de polipropileno \\
V15PP3,5L30 & $15 \%$ de vermiculita e $3,5 \%$ de fibra de polipropileno \\
V20PP3L30 & $20 \%$ de vermiculita e 3,0\% de fibra de polipropileno \\
V25PP2,5L30 & $25 \%$ de vermiculita e $2,5 \%$ de fibra de polipropileno \\
\hline
\end{tabular}

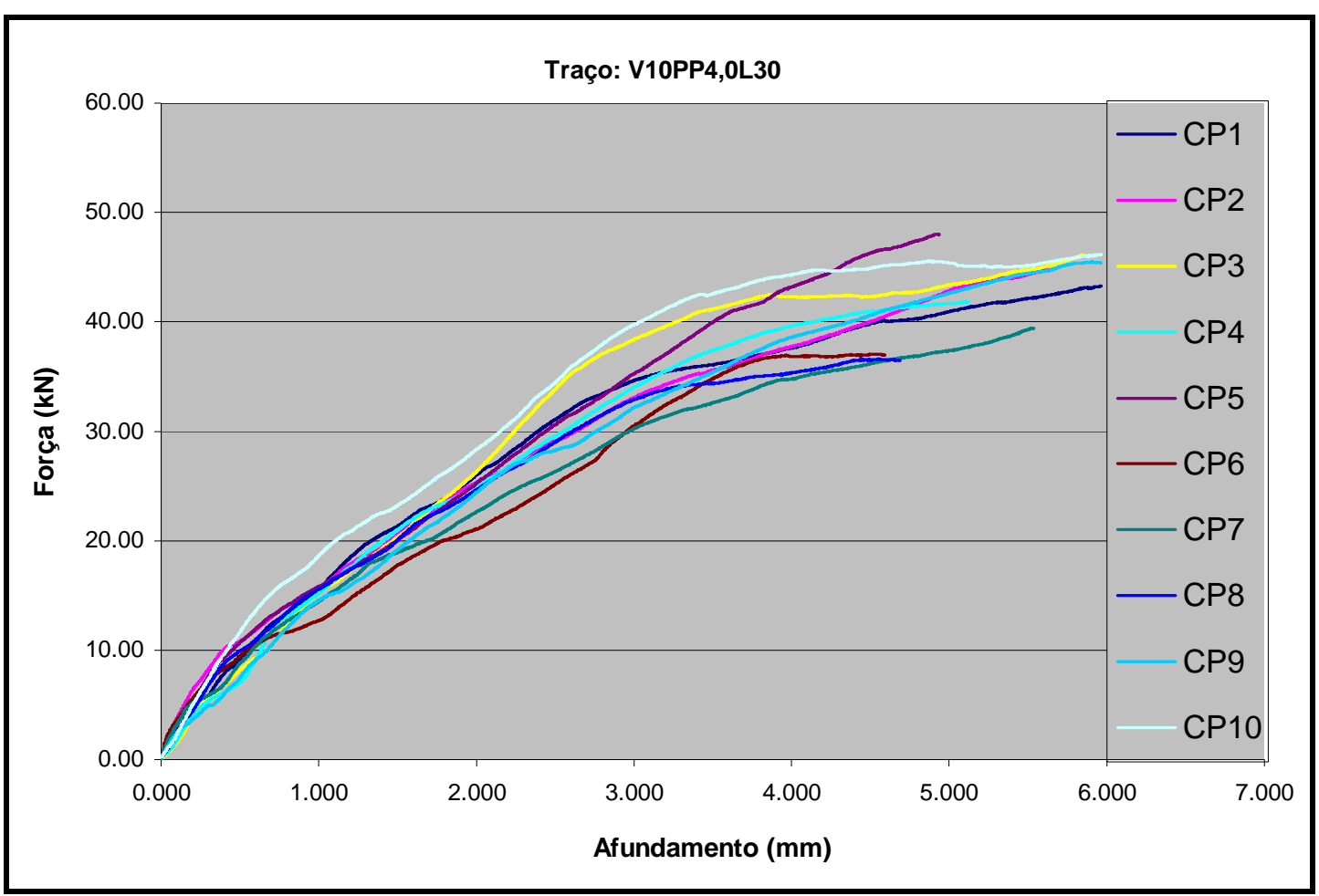

Figura 4.11: Curvas força $x$ deslocamento para o traço V10PP4,0L30.

Com base na Figura 4.11, observou-se as curvas que apresentaram o comportamento mais próximo, eliminando-se as curvas com comportamento muito distinto da maioria e, traçando-se a curva média desse traço, como apresentado na Figura 4.12. Deve-se ressaltar que devido à variabilidade dos resultados de cada tira de almofada, o critério de eliminação das curvas foi puramente visual, devido à falta de outro método melhor de análise da variabilidade das curvas. 


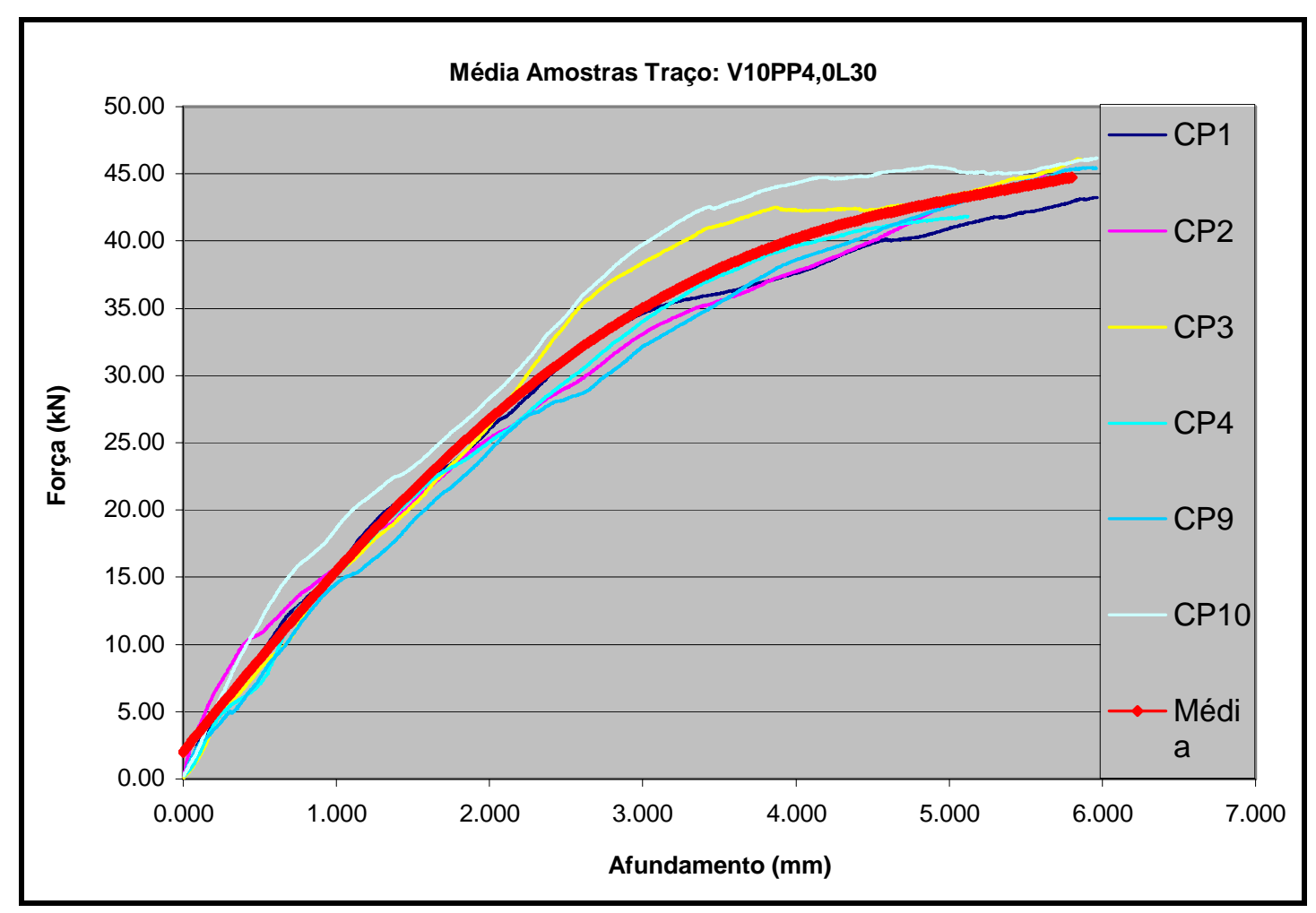

Figura 4.12: Curvas média força $x$ deslocamento para o traço V10PP4,0L30.

\subsection{Ensaios de ligação de blocos}

Para justificar a capacidade de acomodação das almofadas do compósito, utilizou-se um ensaio que promovesse uma comparação entre elementos simulando peças de concreto moldado in loco e peças que foram sobrepostas simulando uma ligação de concreto prémoldado. Estes ensaios são uma seqüência dos experimentos realizados por MONTEDOR (2004) sem a presença de inclinação entre os elementos.

Os ensaios consistiram basicamente em utilizar prismas de concreto com $15 \mathrm{~cm}$ x $15 \mathrm{~cm}$ de base com $30 \mathrm{~cm}$ de altura, que simulavam peças de concreto moldado in loco e cubos de concreto com $15 \mathrm{~cm}$ de lado, onde duas peças foram sobrepostas para simular uma ligação de elementos de concreto pré-moldado (Figura 4.13). 


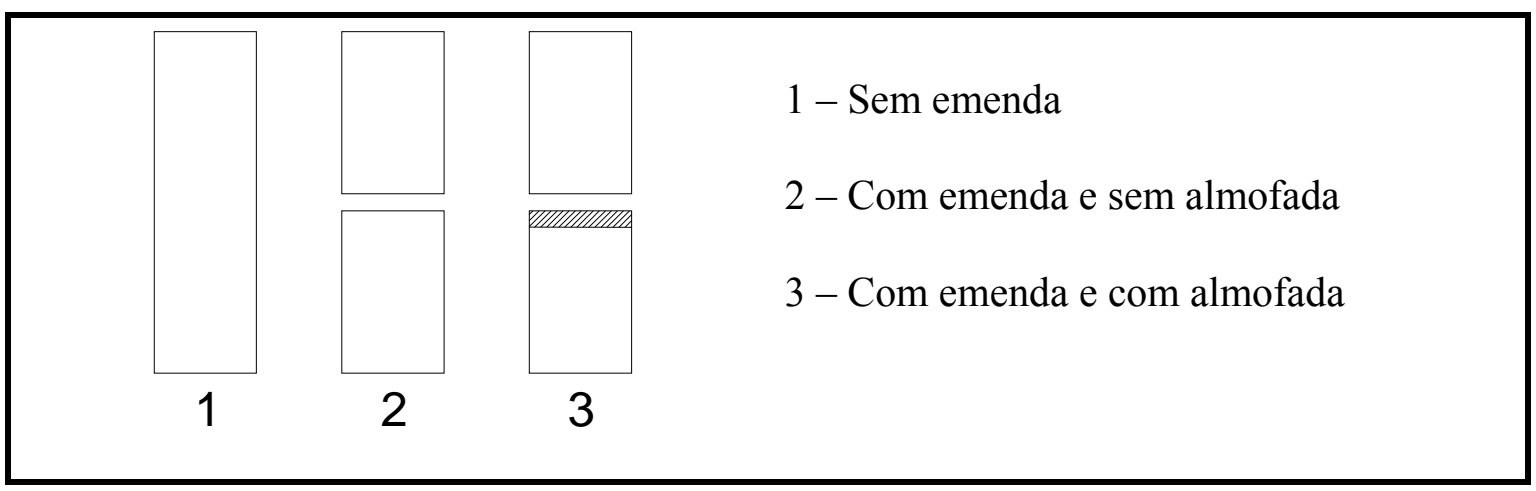

Figura 4.13: Esquema dos ensaios de ligação de blocos.

Nos ensaios simulando ligação entre elementos pré-moldados de concreto, foram realizados ensaios com e sem presença da almofada como elemento de apoio, como visto na Figura 4.13.

Para verificar a efetividade da acomodação das imperfeições das superfícies que formam o contato entre os cubos de concreto, foram introduzidas rugosidades na face de contato do bloco de que seria superposto(Figura 4.14).

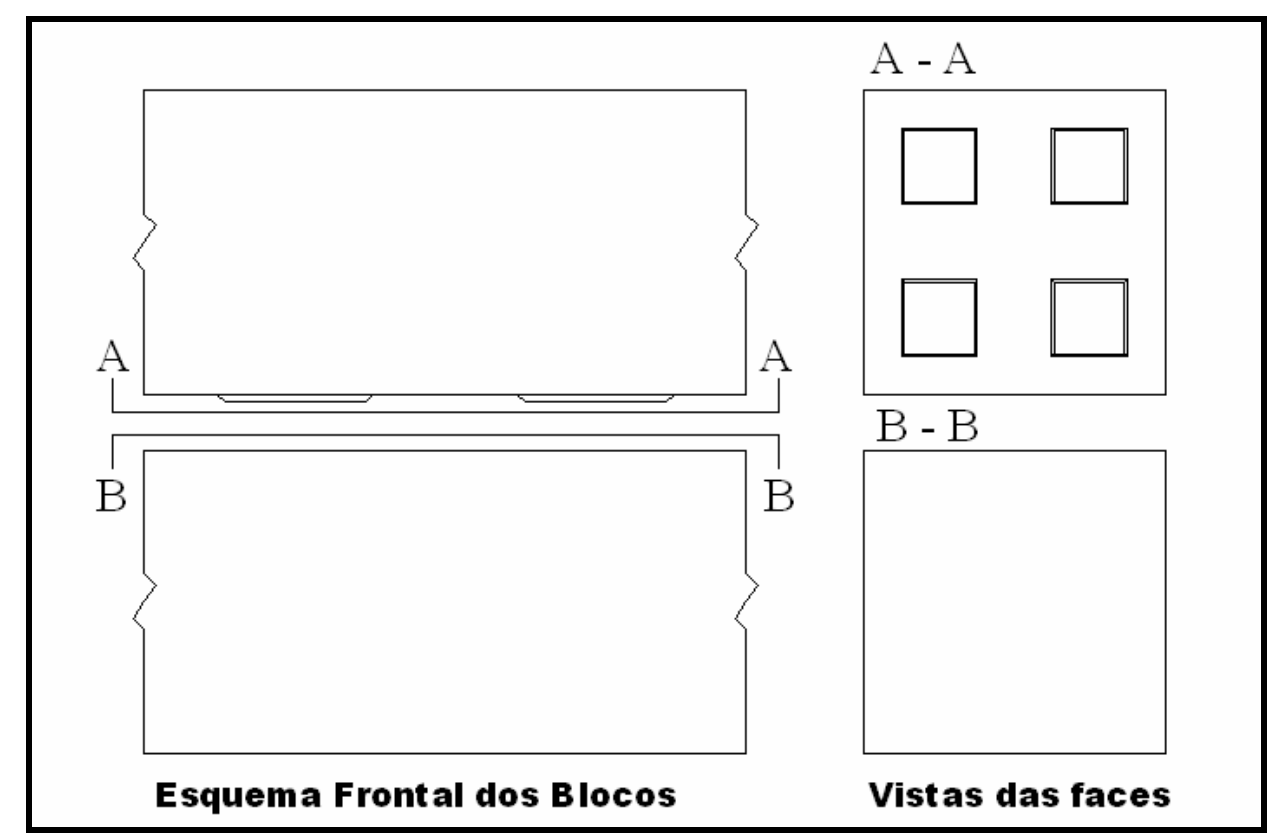

Figura 4.14: Esquema das rugosidades e colocação dos blocos para ensaio. 
Na Figura 4.14 pode-se observar o padrão de rugosidade imposto aos blocos de concreto e o posicionamento dos mesmos para o ensaio. A Figura 4.15 mostra a foto dos três tipos de blocos de concreto utilizados nesta pesquisa.

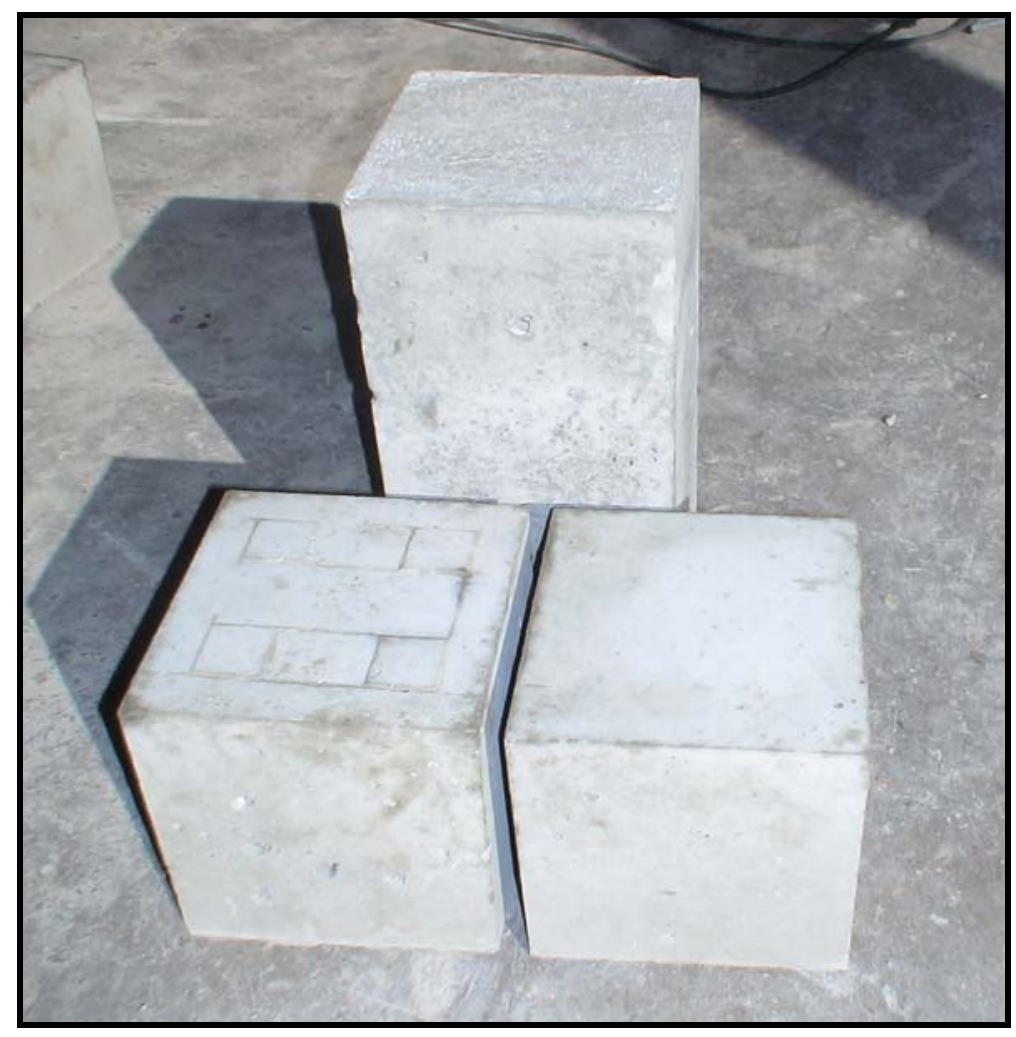

Figura 4.15: Esquema dos tipos de blocos ensaiados.

Para esses ensaios com blocos de concreto, foram introduzidas rugosidades variáveis de maneira que se pudesse verificar a capacidade de acomodação das almofadas com a presença de imperfeições na superfície. Portanto, para facilitar e padronizar a análise dos resultados estes ensaios foram divididos em séries, que serão apresentadas a seguir:

\section{$\underline{1^{a} \text { Série: }}$}

A primeira série de prismas (Figura 4.16) consistiu em ensaiar um grupo de blocos com $30 \mathrm{~cm}$ de altura simulando uma peça de concreto moldada no local e, grupos de blocos com $15 \mathrm{~cm}$ de altura, com superfície lisa sem a presença da almofada e com a presença da almofada na interface de ligação entre os blocos. 


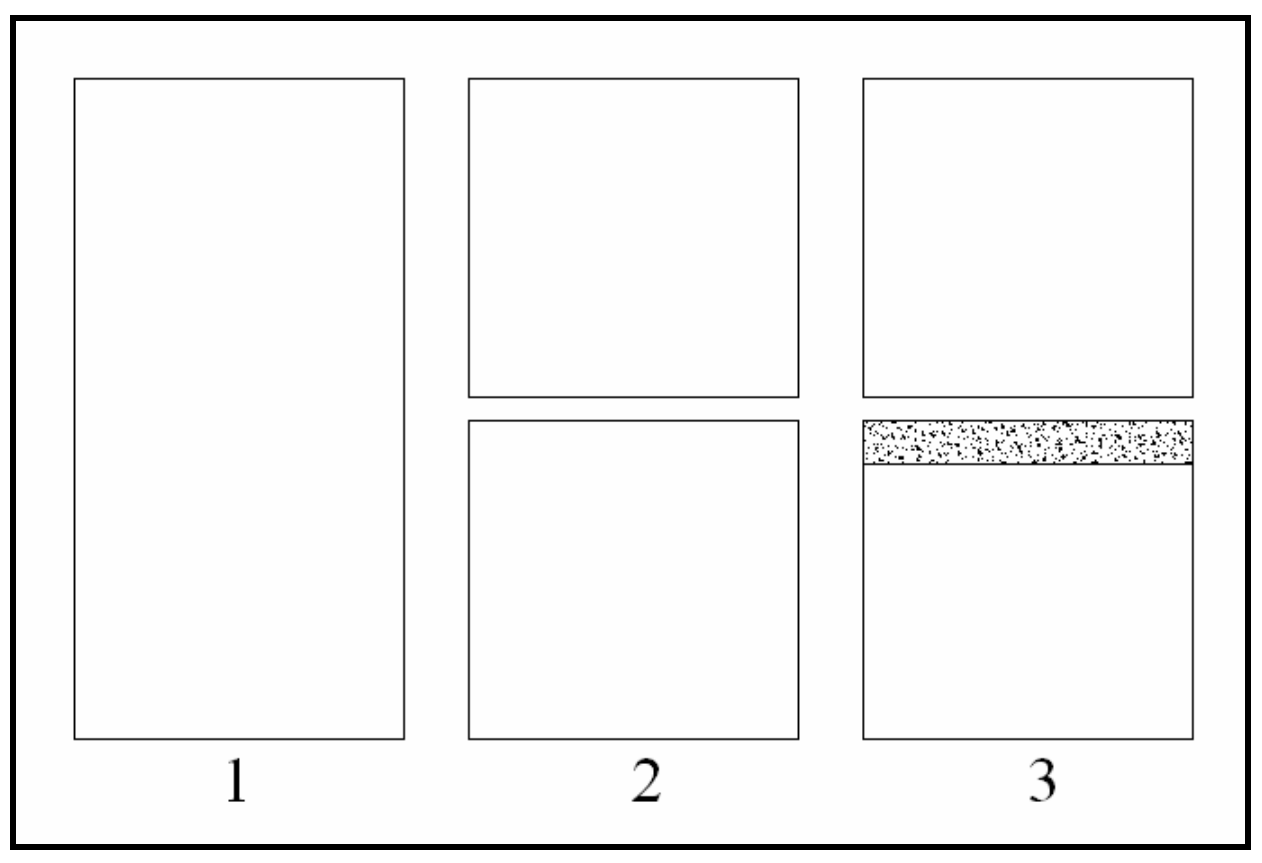

Figura 4.16:- Primeira série de ensaios de blocos.

As almofadas destes ensaios foram fundidas aos blocos de concreto que ficariam na base do elemento, como apresentado na figura, no momento da sua concretagem, para uma melhor interação destes elementos.

\section{$2^{a}$ Série:}

Para a segunda série de ensaios foram ensaiados somente blocos de $15 \mathrm{~cm}$ de altura (Figura 4.17), onde foram introduzidas rugosidades variáveis na face de um dos blocos de concreto. Os valores das rugosidades introduzidas foram de $0,75 \mathrm{~mm}, 1,00 \mathrm{~mm}$ e 1,5mm. Como dito anteriormente, buscava-se assim, a capacidade de acomodação das almofadas na presença de imperfeições nos elementos.

As almofadas desta série de ensaios também foram fundidas aos blocos de concreto no momento da sua concretagem. 


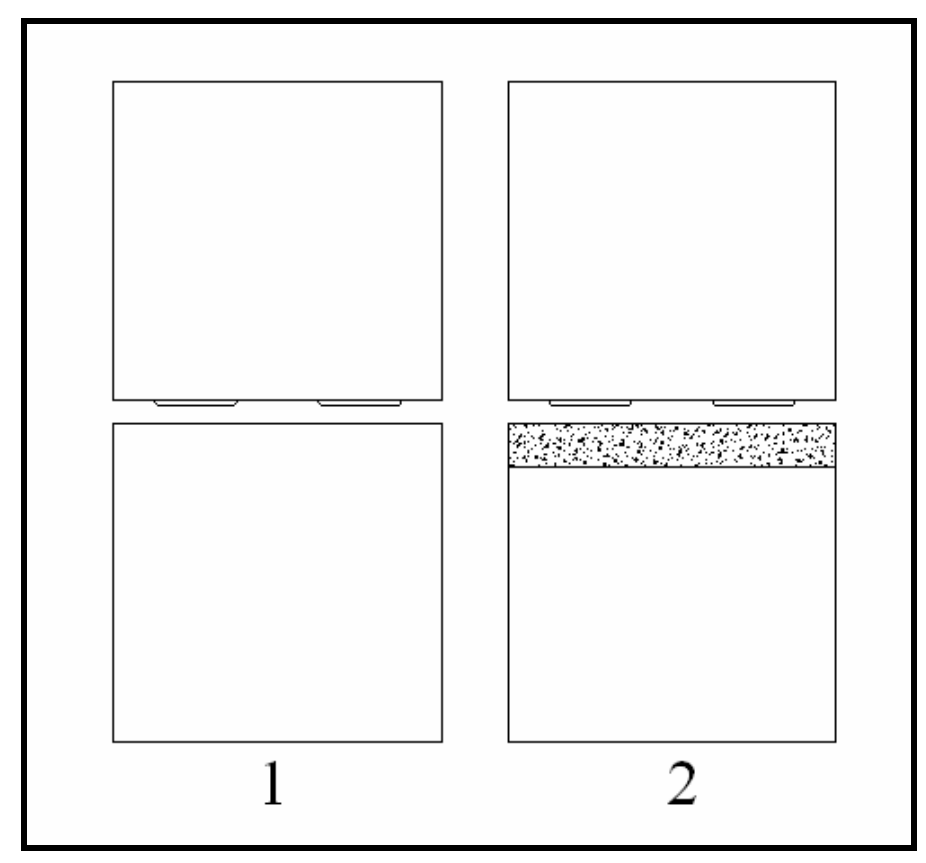

Figura 4.17: Segunda série de ensaios de blocos.

Para cada série, os números das figuras 4.16 e 4.17 indicam uma concretagem diferente, totalizando 9 moldagens em dias diferentes e, para garantir que todos os traços estivessem com um mesmo padrão de resistência do concreto, foram retirados e ensaiados corpo-de-prova cilíndricos com $10 \mathrm{~cm}$ de diâmetro por $20 \mathrm{~cm}$ de altura juntamente os blocos.

Todos os ensaios foram de compressão e realizados na máquina ELLE presente no Laboratório de Estruturas da Escola de Engenharia de São Carlos (EESC/USP). As figuras $4.18 \mathrm{a}$ e $4.18 \mathrm{~b}$ mostram fotos de dois exemplos de ensaios realizados. 


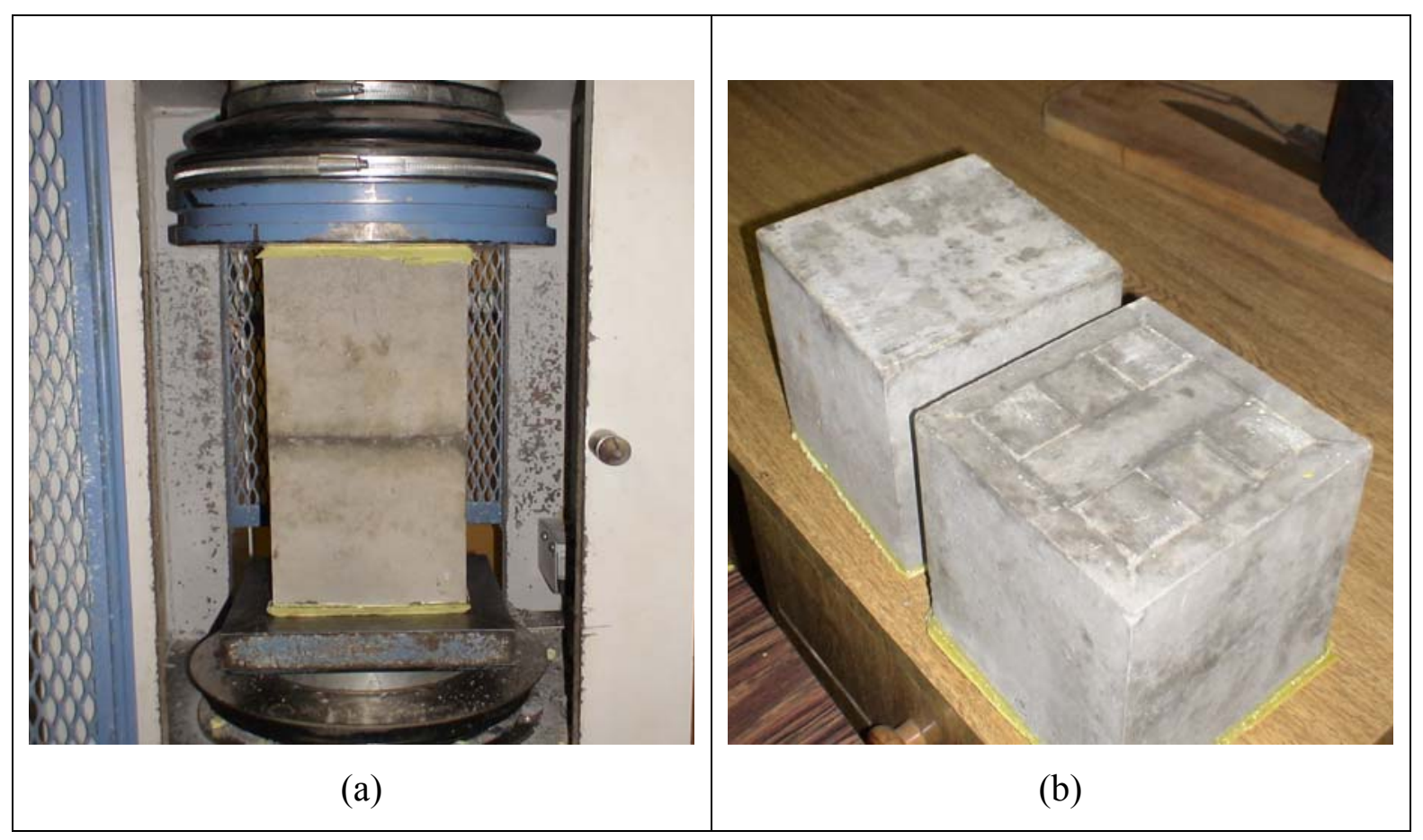

Figura 4.18: (a) Ensaio de blocos lisos sem almofada; (b) blocos para ensaio com rugosidade de $1,5 \mathrm{~mm}$ sem almofada.

\subsection{Ensaios de rotação de apoio}

Finalizando as séries de ensaios em placas foram realizados testes para medir a capacidade de rotação das almofadas. Para tanto um sistema especial de aplicação de carga nas almofadas foi preparado para que se pudesse realmente aplicar valores expressivos de carregamentos que provocassem rotações com valores relativamente altos. Sendo assim, podem-se atingir rotações com valores que foram convencionados como sendo os limites para as almofadas, obtendo-se indicações práticas para a utilização destas. Nas figuras 4.19 e 4.20 são apresentados os esquemas básicos do ensaio.

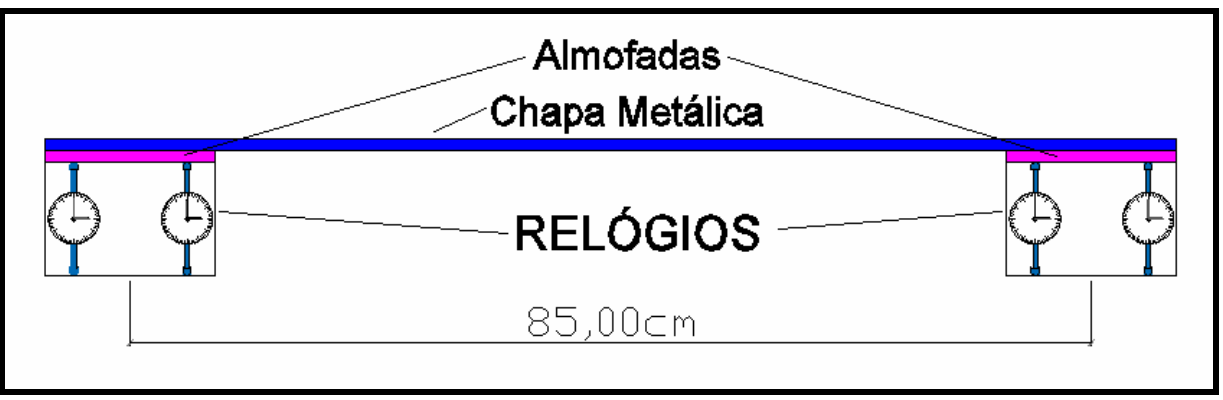

Figura 4.19: Esquema básico do ensaio de rotação. 


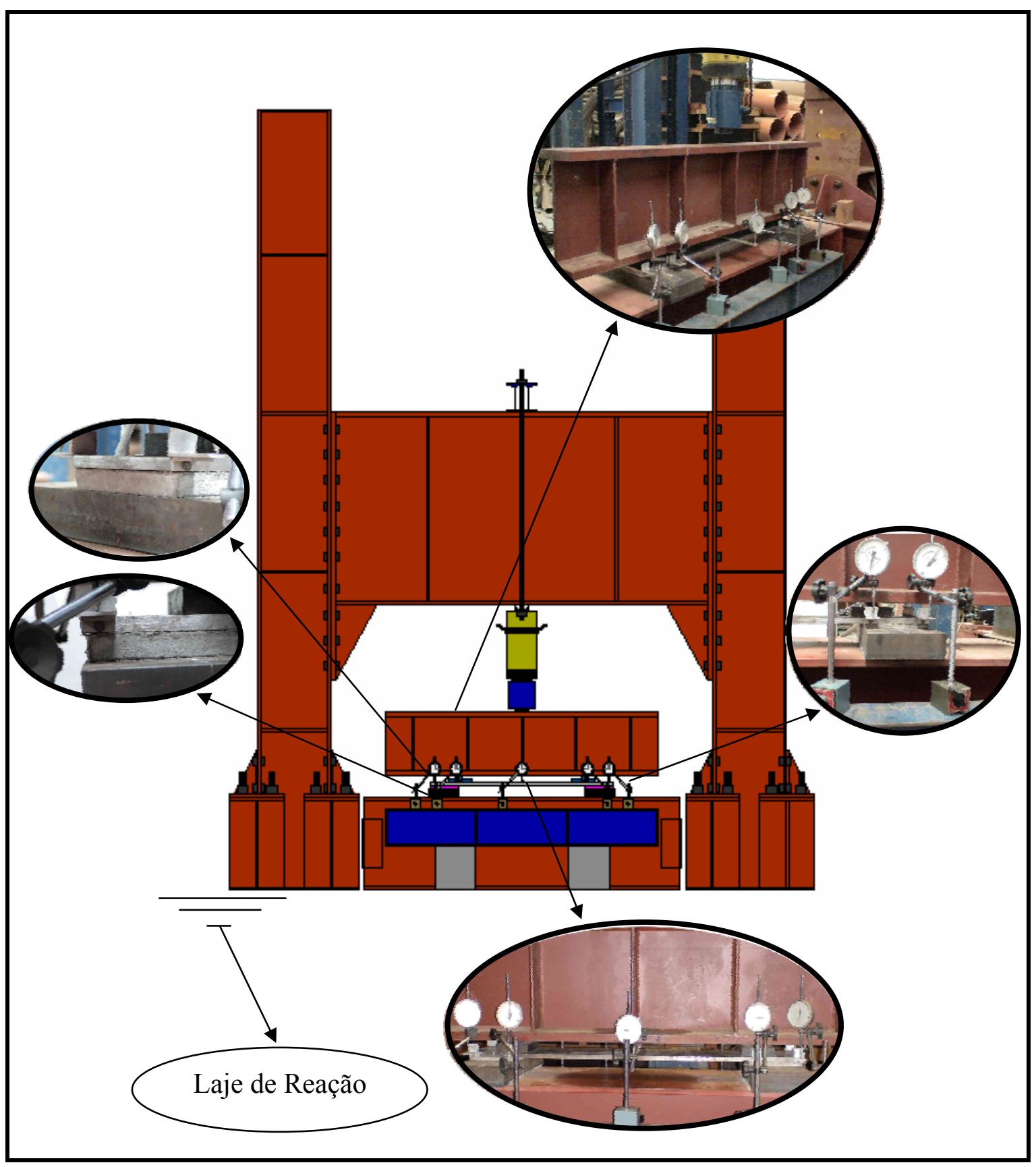

Figura 4.20: Esquema íntegro do ensaio de rotação.

Este ensaio foi dimensionado de maneira que as rotações aplicadas nas almofadas fossem maiores que as observadas em situações práticas onde se pode lançar mão do uso do compósito. Para tanto, utilizou-se como referência para o dimensionamento da chapa metálica, uma viga de ponte rolante do laboratório de Estruturas da EESC/USP, onde os giros máximos que poderiam ser observados nestas foram adotados como valores mínimos de rotações a serem aplicadas nas almofadas. Essa viga suporta uma 
ponte rolante com capacidade de 6 toneladas. Como essa é uma viga protendida e, consequentemente, os valores das rotações seriam diminuídos devido aos efeitos da protensão, o cálculo foi realizado desprezando-se a protensão, ou seja, os valores das rotações foram majorados para o caso.

Como pode ser observado nas figuras 4.19 e 4.20, para que se pudesse promover uma efetiva rotação na almofada foi utilizada uma chapa metálica de $100 \mathrm{~cm}$ de comprimento, largura de $15 \mathrm{~cm}$ e espessura de $12,5 \mathrm{~mm}$ sobre a qual, nas extremidades, foram colocadas almofadas do compósito atuando como um elemento de apoio submetido a rotação. Sobre esta chapa foram aplicadas cargas duas excêntricas próximas aos apoios. O ensaio pode ser comparado a um ensaio de flexão em quatro pontos, sendo que, os pontos de aplicação de carga ficam com uma pequena excentricidade em relação ao centro médio dos apoios (Figura 4.21).

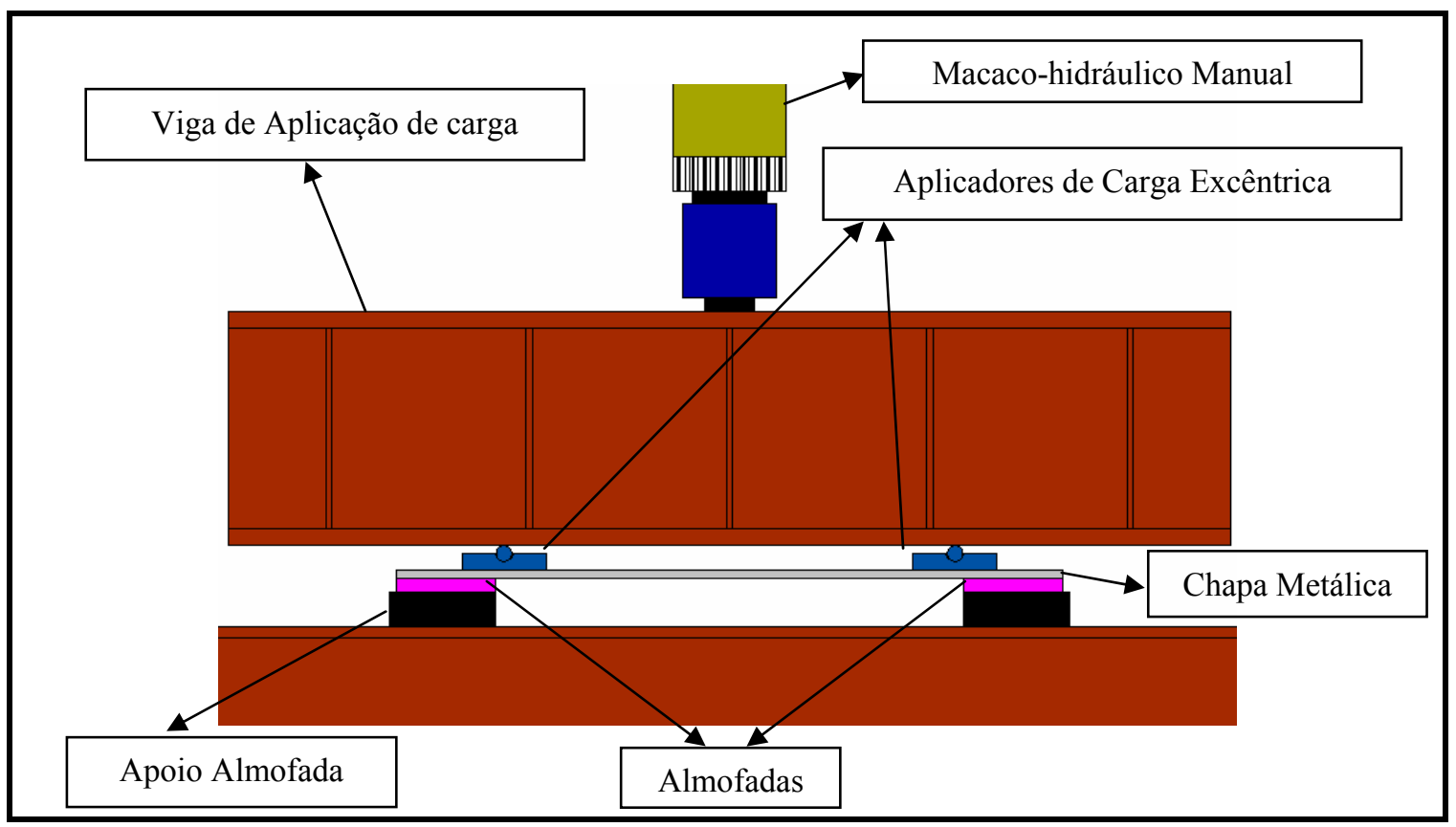

Figura 4.21: Detalhes do ensaio de rotação.

A carga foi aplicada por meio de um macaco-hidráulico manual, com capacidade de 100 toneladas. Para distribuição das forças para a chapa foi utilizada uma viga metálica de Perfil I com 350mm de altura com cinco enrigecedores de cada lado da peça para garantir que essa não sofresse deformação gradativa no processo de aplicação das forças. Os distribuidores de carga foram pensados de maneira que as posições da 
resultante das forças aplicadas aos apoios tivessem as excentricidades requeridas e as tensões aplicadas à chapa metálica não provocassem nenhum tipo de deformação plástica na mesma.

Foram posicionados cinco relógios analógicos com precisão de $0,01 \mathrm{~mm}$ (centésimo de milímetro) de cada lado da chapa. Em cada lado dos apoios colocou-se dois relógios para verificação das diferenças de afundamento sofridas na almofada, tornando possível o cálculo das rotações sofridas. No centro da chapa metálica foi posicionado um relógio, que ficou incumbido do controle de deslocamento desse ponto para que a tensão de escoamento desta não fosse atingida.

Neste ensaio foi adotada uma convenção dos relógios e das vistas da chapa metálica (Figura 4.22) de maneira a facilitar a visualização e interpretação dos resultados medidos.

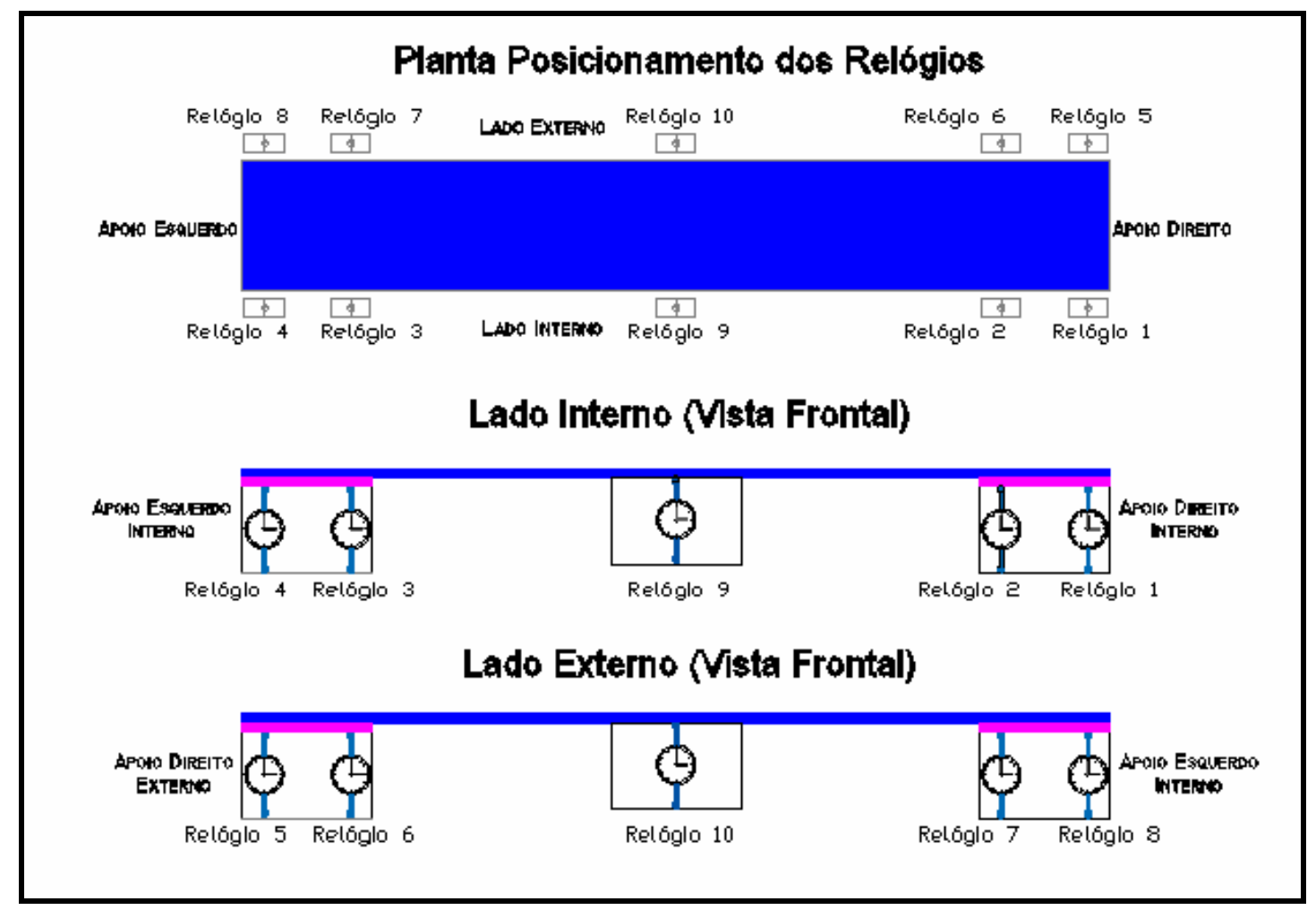

Figura 4.22: Convenção adotada para os ensaios.

As almofadas utilizadas possuíam $15 \mathrm{~cm}$ de base com espessuras de $10 \mathrm{~mm}$ e $20 \mathrm{~mm}$. Nesta fase de ensaios, como feito nos ensaios de ligação de bloco, não foram testados 
todos os traços das almofadas. Como o traço V10PP4L30 se apresentou com as características desejadas nos ensaios anteriores, os ensaios foram concentrados neste e nos traços com suas porcentagens, respectivamente, abaixo e acima deste, ou seja, os traços V5PP4,5L30 e o V15PP3,5L30. A tentativa foi de se obter uma gama de resultados em torno desse traço com 10\% de vermiculita para sua aplicação.

A aplicação de carga foi realizada manualmente e por etapas, sendo que, em cada etapa aplicou-se um incremento de $100 \mathrm{kN}$ de carga e os valores de cada relógio analógico foram lidos e anotados em uma planilha preparada para o ensaio. A carga máxima aplicada foi a de 900kN (90ton.) devido a limitação do macaco-hidráulico.

As excentricidades foram testadas de maneira empírica numa primeira etapa para que, com o carregamento aplicado e o giro sofrido pela chapa metálica, não houvesse um descolamento desta com a superfície da almofada, como pode ser visto na Figura 4.23.

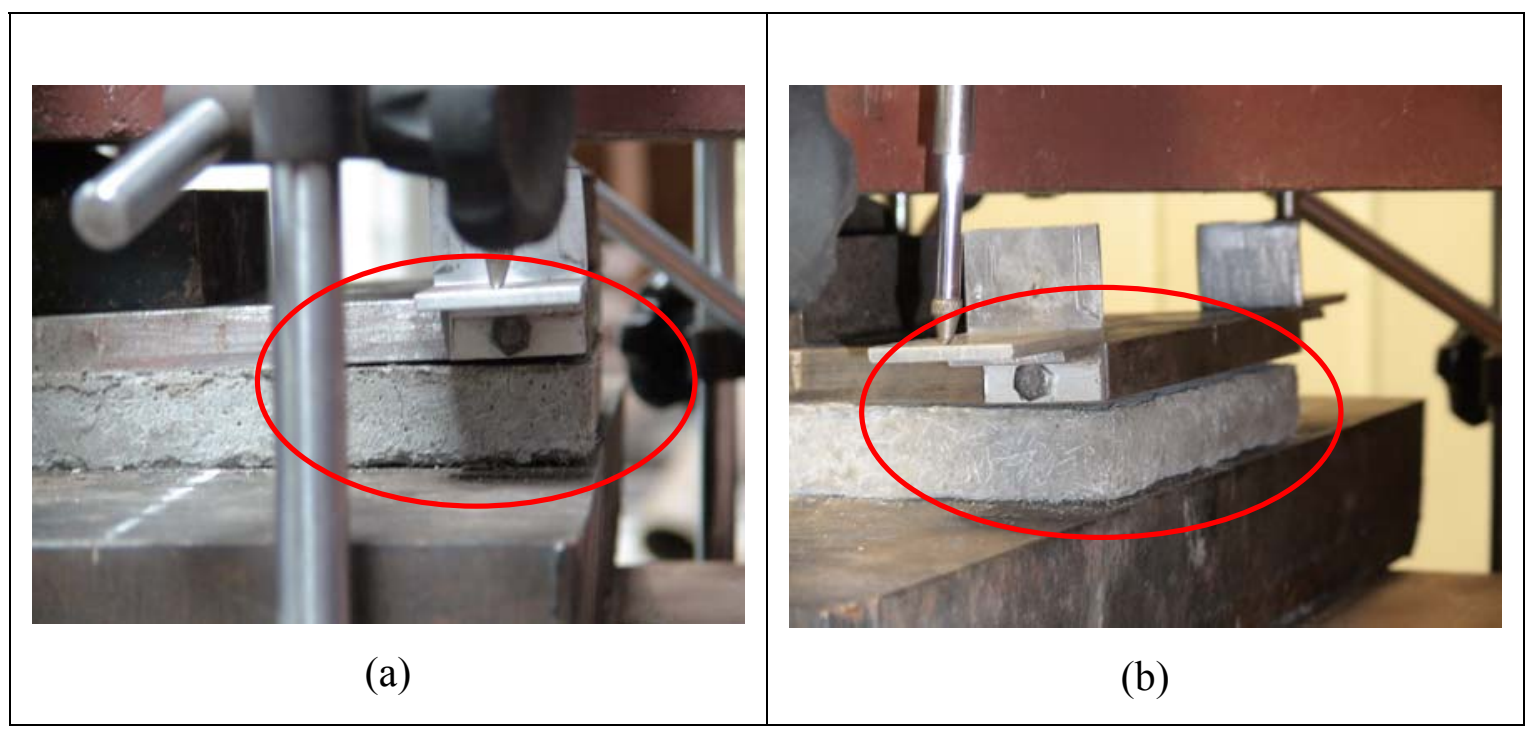

Figura 4.23: (a) e (b) Descolamento da extremidade da chapa em relação a superfície da almofada.

Para as almofadas de $10 \mathrm{~mm}$ de espessura a excentricidade obtida e adotada entre a posição da resultante do carregamento em relação ao centro do apoio foi de $60,0 \mathrm{~mm}$. Nos ensaios com almofadas de $20 \mathrm{~mm}$ essa excentricidade teve que ser diminuída para $55,0 \mathrm{~mm}$ para não ocorrer o descolamento entre as superfícies da almofada e da chapa metálica. 
Os relógios comparadores utilizados na obtenção dos resultados foram todos montados com base magnética em vigas metálicas, posicionadas em frente ao pórtico de reação utilizado para o ensaio (Figura 4.24). Esse cuidado foi tomado de maneira que os resultados das medidas dos relógios não sofressem interferências de deformações e acomodações sofridas pelo pórtico.

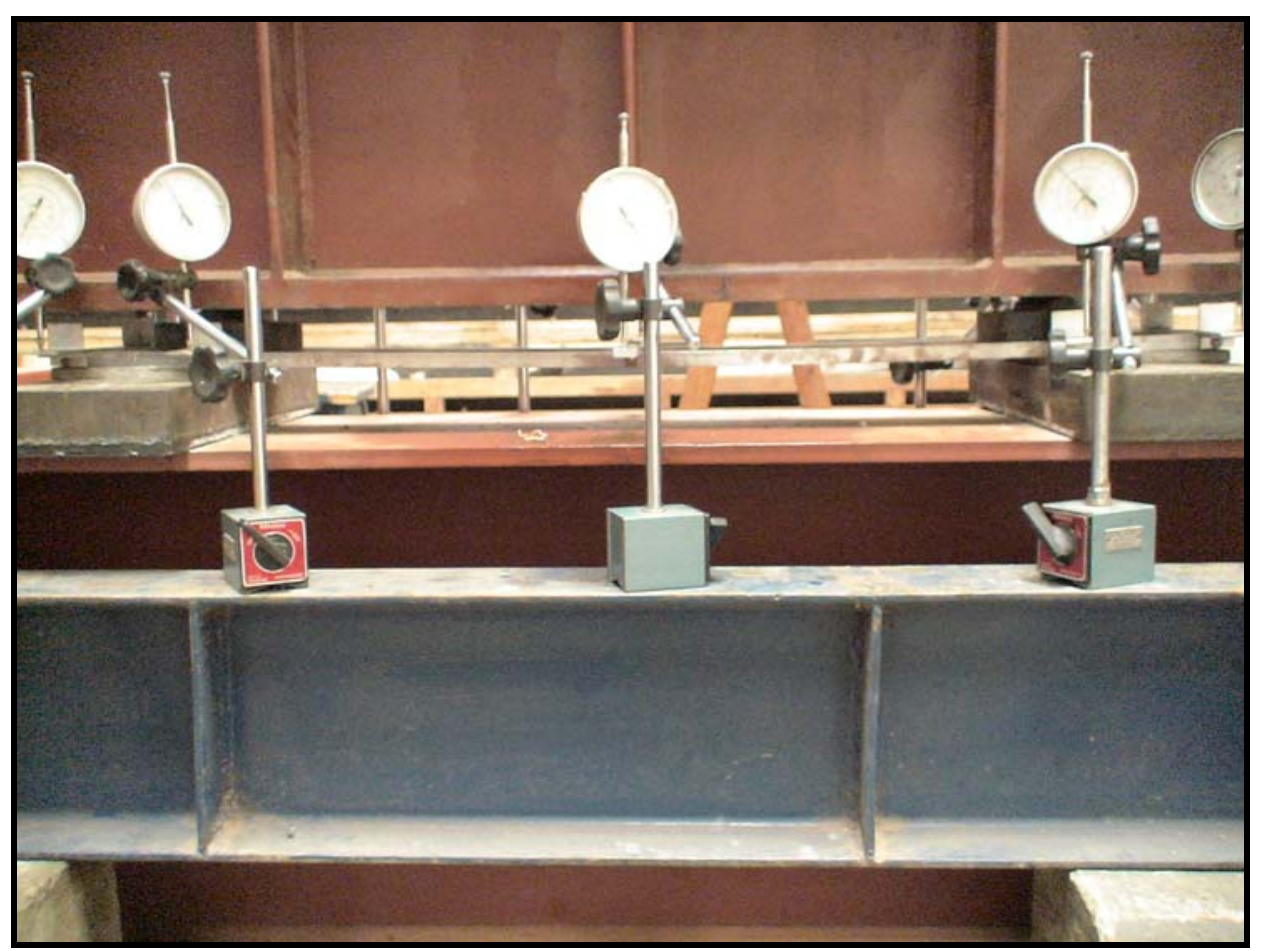

Figura 4.24: Relógios com bases magnéticas posicionados sobre base metálica.

Todos os relógios utilizados eram da marca Mitutoyo, sendo a capacidade de leitura de $50 \mathrm{~mm}$ para os relógios posicionados sobre os apoios e $30 \mathrm{~mm}$ para os alocados no meio do vão da chapa metálica.

\subsection{Ensaio de tenacidade ao fraturamento}

Os ensaios de fraturamento foram realizados com o intuito inicial de determinar a tenacidade flexional do material. Devido à grande deformabilidade apresentada pelo mesmo, bem como às limitações de curso do clip-gauge (transdutor de deslocamentos) disponível para o controle do ensaio, o objetivo inicial não pôde ser totalmente atingido. Mesmo assim, alguns resultados de caráter qualitativo puderam ser obtidos. As 
recomendações adotadas para a condução dos ensaios foram as da RILEM TC 162-TDF (2002). Apesar de destinadas à obtenção de parâmetros de tenacidade ao fraturamento de compósito reforçados com fibras de aço, as recomendações referidas foram empregadas para a determinação de indicadores da tenacidade ao fraturamento do compósito com fibras de polipropileno, investigado nesta pesquisa.

Os ensaios foram conduzidos submetendo-se pequenas vigas moldadas com 0 compósito aqui estudado, à flexão em três pontos. Cada viga foi entalhada no centro do vão objetivando a criação de um plano preferencial de fraturamento, em virtude da fragilização da seção transversal (Figura 4.25).

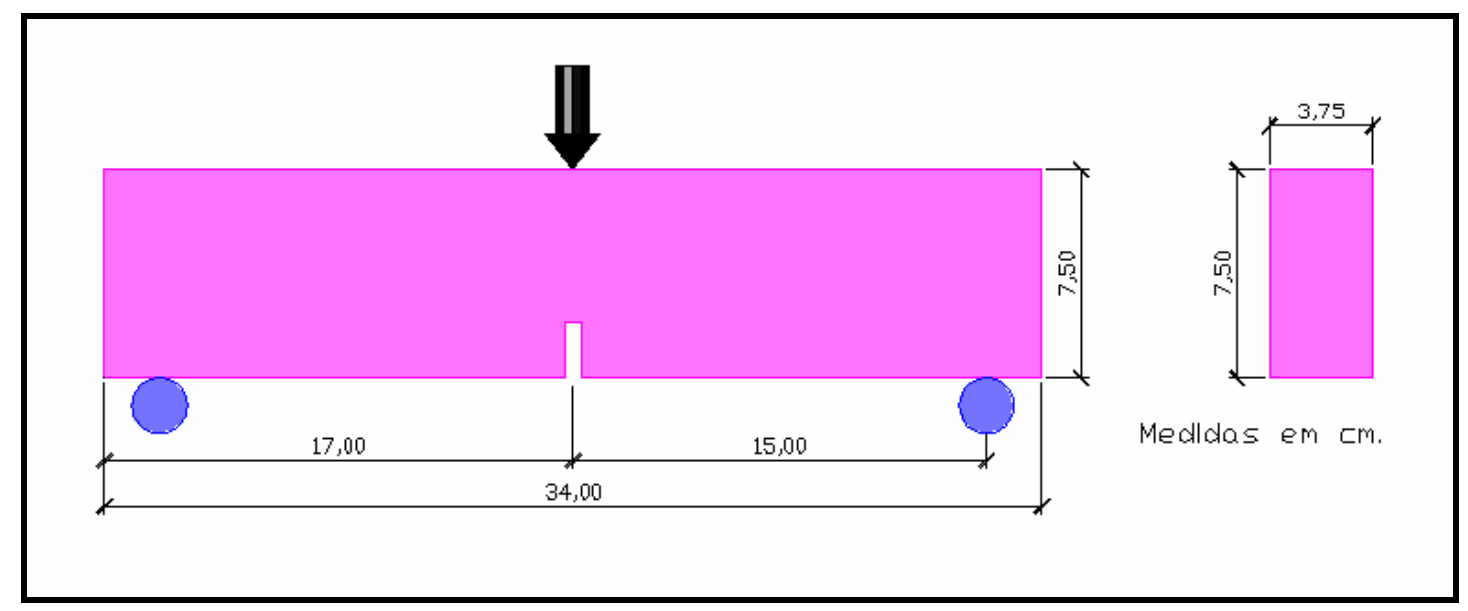

Figura 4.25: Esquema do ensaio de tenacidade ao fraturamento à flexão em três pontos.

Como pode ser observado na Figura 4.24, o comprimento nominal (1) adotado para as vigas foi de $34,00 \mathrm{~cm}$, objetivando a obtenção de vãos livres (s) iguais a $30,0 \mathrm{~cm}$. Todas as outras medidas respeitaram proporções usualmente utilizadas em ensaios desta natureza, ou seja, alturas (w) larguras (b) e profundidades dos entalhes $\left(\mathrm{a}_{0}\right)$ correspondentes a 1/4,1/8 e 1/16 do vão livre, respectivamente. As medidas adotadas resultaram, portanto, da adequação das proporções recomendadas pela RILEM para corpos-de-prova utilizados em ensaios de concreto com fibras, ao material da pesquisa.

Os parâmetros obtidos nos ensaio de fraturamento foram a tensão limite de proporcionalidade ou tensão limite da fase elástica, $\mathrm{f}_{\mathrm{fct}, \mathrm{L}}$, que corresponde à contribuição da matriz de cimento na resistência global do compósito, e as tensões residuais à tração na flexão, $\mathrm{f}_{\mathrm{R}, \mathrm{i}}$. Estas últimas podem ser traduzidas como valores da efetiva contribuição 
da fibra na resistência do compósito com a evolução do carregamento e do processo de fissuração.

Neste caso, os valores dos deslocamentos verticais da linha de carga, que são utilizados como pontos chave no cálculo dos parâmetros do ensaio, foram alterados respeitando-se as proporções indicadas nas recomendações. A Figura 4.26 apresenta esquematicamente os deslocamentos utilizados para a obtenção dos valores das tensões de interesse.

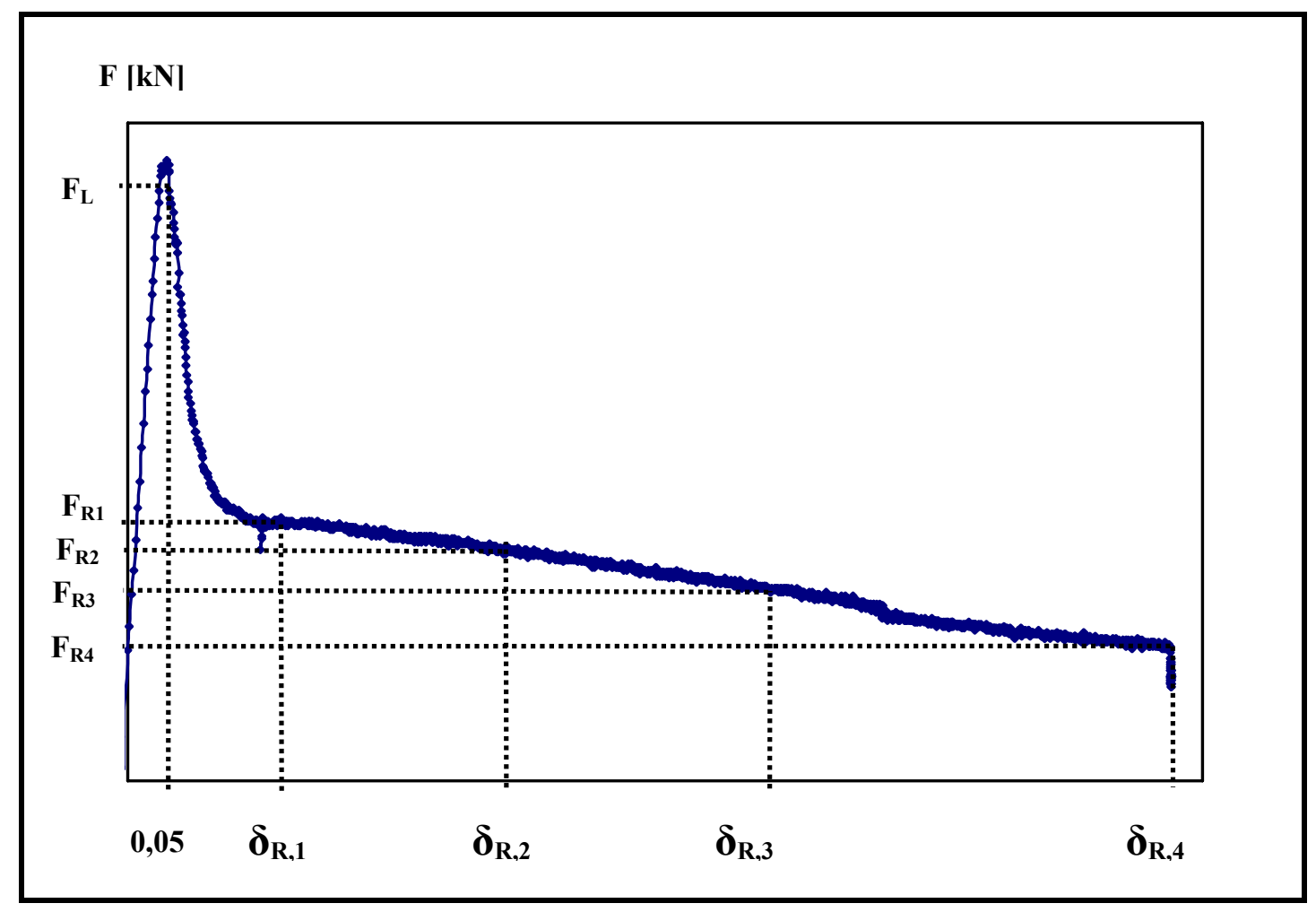

Figura 4.26: Deflexões importantes ao ensaio de tenacidade ao fraturamento.

Para o cálculo da tensão limite de proporcionalidade, $\mathrm{f}_{\mathrm{fct}, \mathrm{L}}$, utiliza-se a força denominada $\mathrm{F}_{\mathrm{L}}$, correspondente ao deslocamento de $0,05 \mathrm{~mm}$. Os demais valores de deslocamentos verticais da linha de carga, $\delta_{R, i}$, necessários aos cálculos das resistências residuais, são padronizados. A esses valores correspondem forças residuais $\mathrm{F}_{\mathrm{Ri}}$. Os deslocamentos verticais residuais apresentados na Figura 4.26, são frações do vão livre da viga com 0,276mm (1/1087), $\quad 0,786 \mathrm{~mm} \quad(1 / 382), \quad 1,29 \mathrm{~mm} \quad(1 / 233)$ e $\quad 1,80 \mathrm{~mm} \quad(1 / 167)$, respectivamente. 
Para o cálculo das tensões residuais é utilizada a equação apresentada a seguir, que decorre da teoria elementar de vigas:

$$
f_{R, i}=\frac{3}{2} \frac{F_{R, i} \cdot l}{b \cdot h_{s p}{ }^{2}}
$$

Onde:

$f_{R, i}=$ tensão residual para o deslocamento $\mathrm{i}$;

$F_{R, i}=$ força correspondente ao deslocamento i;

$l=$ vão livre da viga;

$b=$ base da viga;

$h_{s p}=$ altura do ligamento (altura da viga menos a altura do entalhe inicial e que corresponde à altura resistente à fissuração).

Para a execução dos ensaios foram utilizados apoios móveis com o objetivo de garantir liberdade de translação horizontal nas extremidades das vigas. Para o controle e a monitoração dos ensaios foram utilizados dois transdutores de deslocamentos, um posicionado na abertura do entalhe e o outro, sob a linha de carga. O primeiro deles, um clip-gauge de controle, foi posicionado na peça para o acompanhamento da abertura da fissura e conseqüente controle do ensaio. O segundo transdutor, um LVDT, foi posicionado no centro do vão de maneira a monitorar os deslocamentos verticais da peça nesta posição.

Entretanto, os ensaios não puderam ser realizados até o final. Conforme citado, o clipgauge posicionado sobre a viga possuía curso máximo de $2,0 \mathrm{~mm}$, valor inferior àqueles obtidos para as aberturas das fissuras. Assim, os dados decorrentes dos ensaios acabaram sendo insuficientes ao cálculo de todos os parâmetros de tenacidade flexional que poderiam ser conseguidos em ensaio desta natureza. Este fato terminou por limitar as análises à avaliação qualitativa da efetividade das fibras incorporadas ao compósito. A Figura 4.27 mostra alguns detalhes do ensaio.

Para a fixação do transdutor destinado à monitoração dos deslocamentos verticais, utilizou-se um suporte construído com uma fina chapa metálica, dobrada e posicionada em frente à viga por meio de sargentos metálicos. Estes, por sua vez, foram colocados 
sobre os apoios para evitar a introdução de esforços adicionais estranhos ao ensaio. $\mathrm{Na}$ extremidade superior da viga, sob o ponto de transmissão da carga, colocou-se uma cantoneira de alumínio para servir de apoio superior ao LVDT. Estes detalhes podem ser observados na Figura 4.27d.

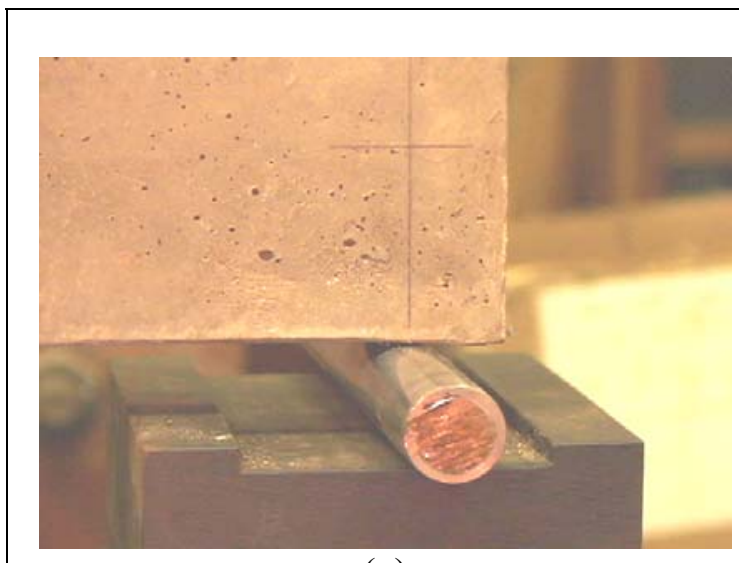

(a)

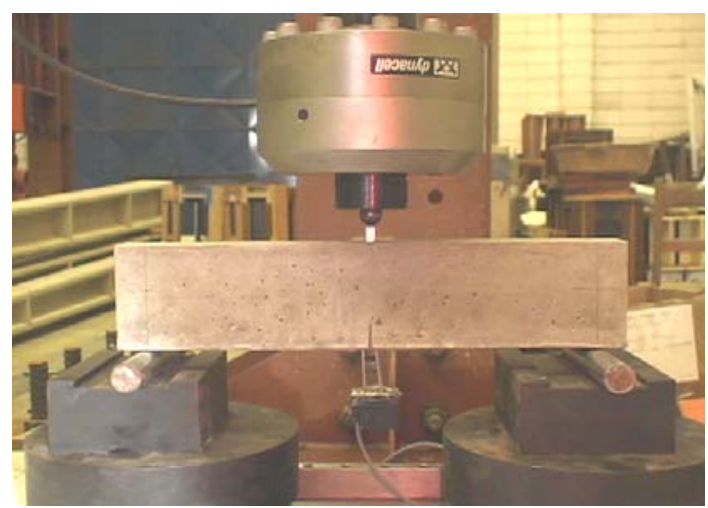

(c)

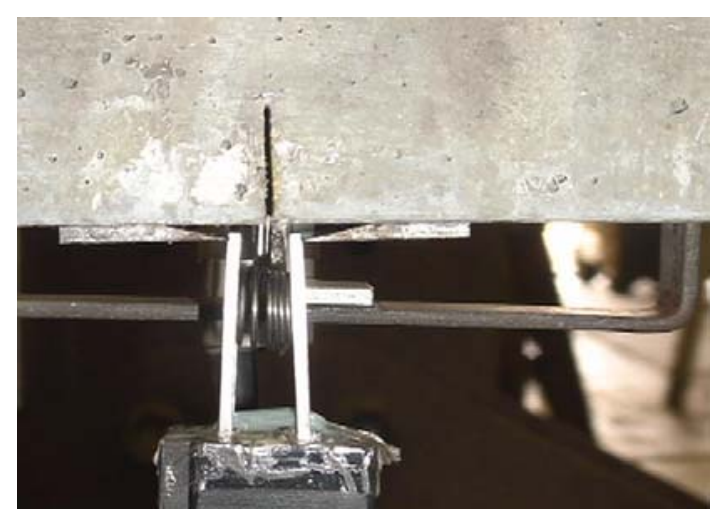

(b)

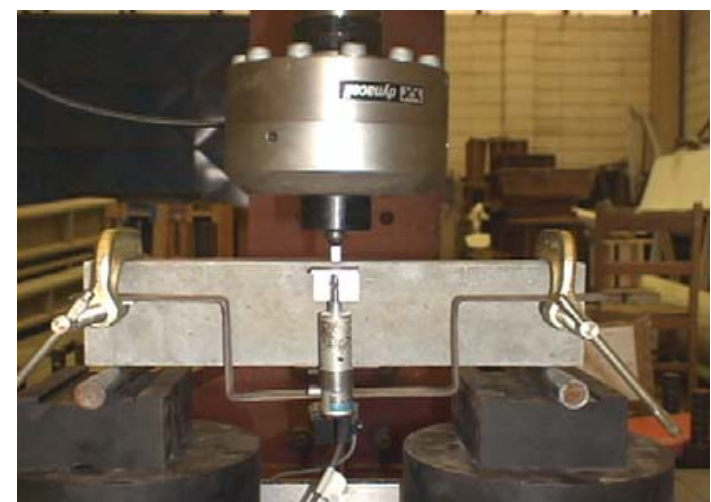

(d)

Figura 4.27: (a) Apoio móvel; (b) clip-gauge de medição da abertura da fissura; (c) detalhe do ensaio sem o LVDT de monitoração dos deslocamentos verticais; (d) esquema completo do ensaio.

Um aspecto importante a ser ressaltado é que os deslocamentos monitorados nos ensaios foram medidos sempre relativamente à própria viga, uma vez que nenhum elemento externo para fixação dos transdutores foi utilizado, o que garantiu a medida de deslocamentos relativos. Esta é uma exigência neste tipo de ensaio.

\subsection{Microscopia ótica}

Ao final de todos os ensaios com almofada, acreditou-se que devido ao processo de moldagem das mesmas, as imperfeições presentes em sua face superior seriam benéficas 
para produzir melhores efeitos de acomodação quando estas estivessem em uso. Para tanto, resolveu-se verificar o padrão dessa rugosidade superficial por meio de fotos de microscópio ótico com uma ampliação suficientemente grande de maneira a se visualizar como estava se apresentando este padrão. A Figura 4.28 mostra um detalhe da moldagem de uma peça.

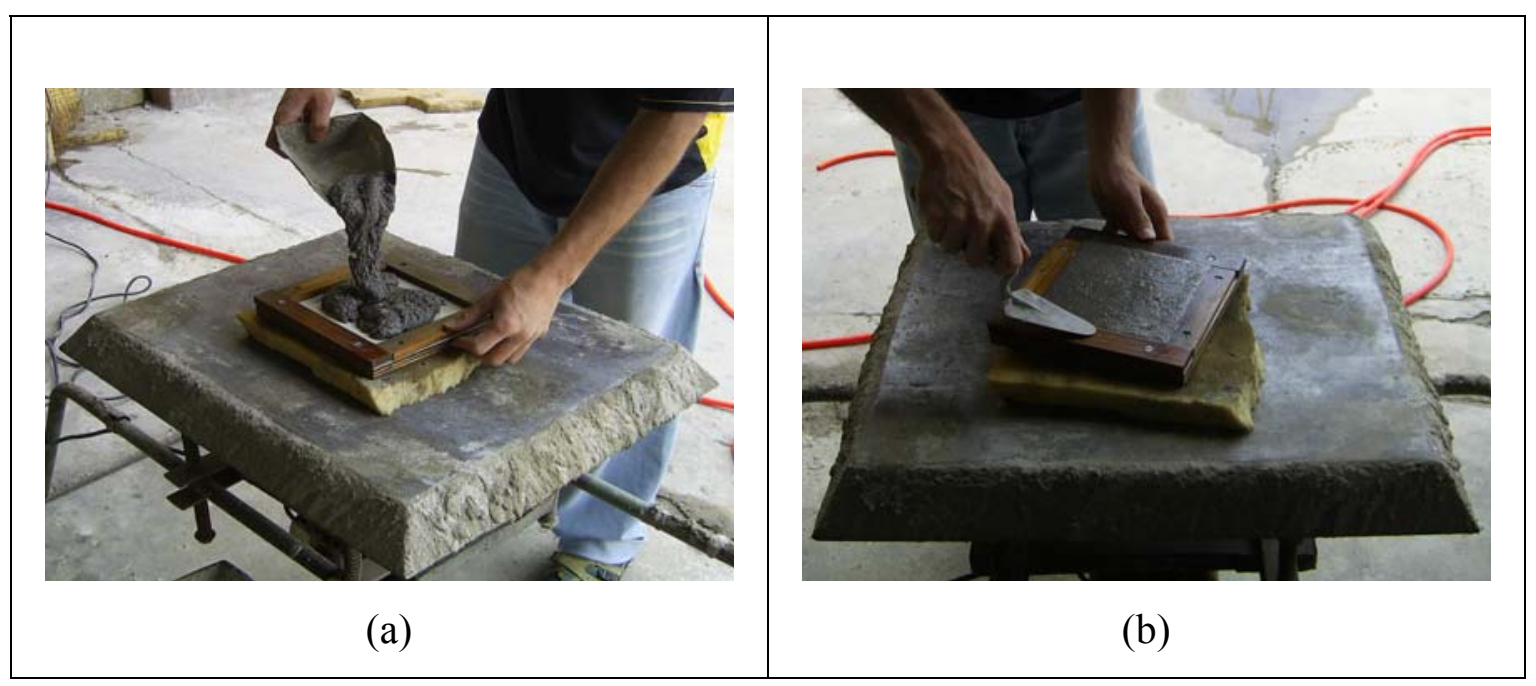

Figura 4.28: (a) Colocação da argamassa na forma; (b) acabamento superficial da almofada.

De acordo com a Figura 4.28 pode-se observar que na superfície inferior da almofada, devido ao fundo das fôrmas devidamente lisas, a almofada não apresenta padrão de rugosidade superficial, sendo perfeitamente lisa.

Para a captura das fotos do compósito foi retirada uma pequena amostra do meio de uma almofada não ensaiada e uma pequena amostra de uma almofada submetida ao ensaio cíclico de carregamento. Com estas fotos visa-se mostrar o padrão de rugosidade apresentado antes dos carregamentos na almofada e depois dos mesmos. A Figura 4.29 apresenta o esquema da retirada da amostra.

As amostras foram cortadas somente com disco especial de corte para cerâmica, não tendo-se nenhum outro tipo de cuidado especial durante a sua retirada, portanto, neste tipo de análise, não tenta-se mostrar a precisão de uma foto retirada por meio de microscopia eletrônica de varredura (MEV), mas sim uma idéia das rugosidades antes e depois de ensaiadas. 


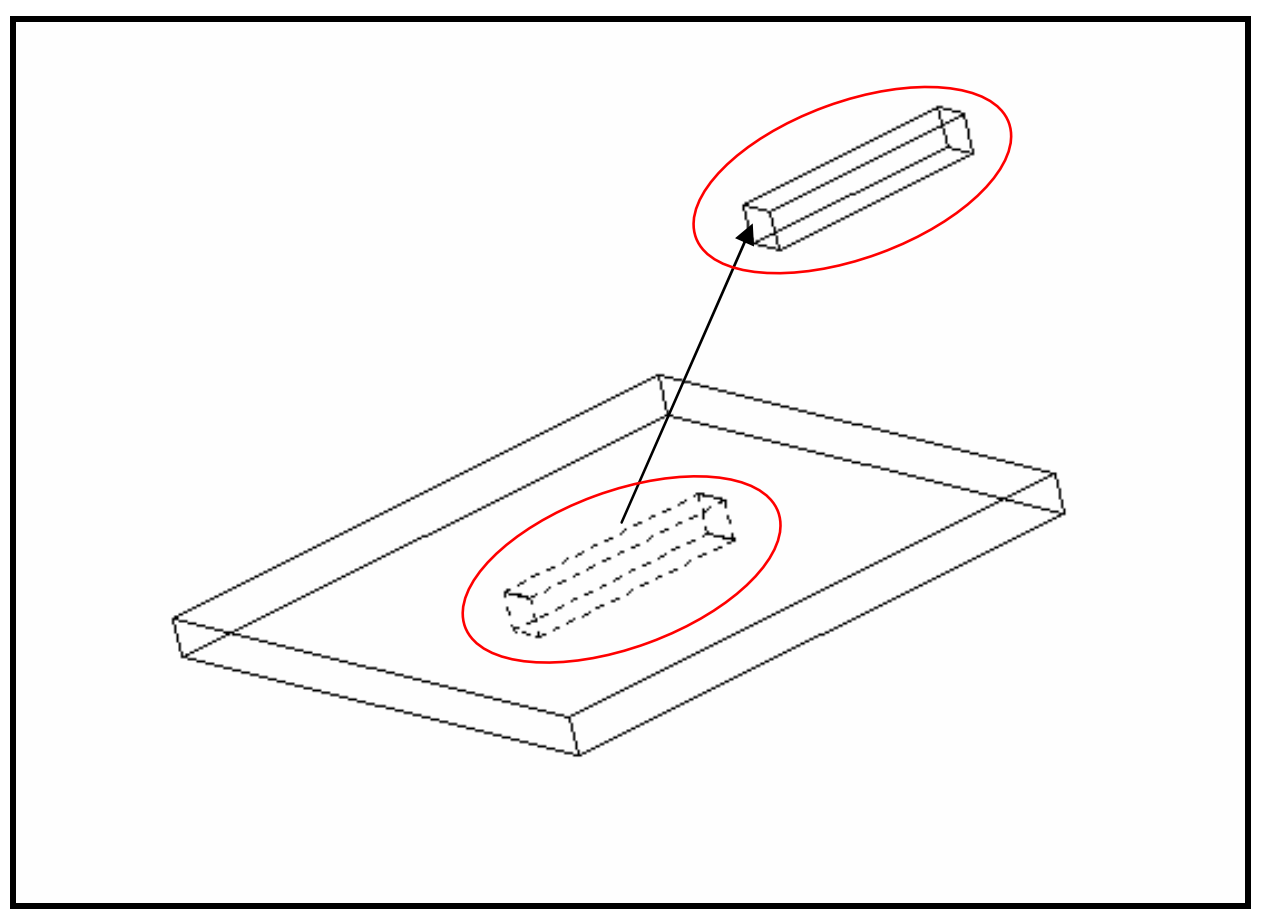

Figura 4.29: Esquema da retirada de amostra das almofadas.

\subsection{Síntese do programa experimental}

A síntese do programa experimental (Tabela 4.3) foi introduzida neste ponto do texto para facilitar o entendimento e ajudar no processo de visualização dos resultados que será apresentado no próximo capítulo. Nela são apresentados os principais pontos dos estudos desenvolvidos com uma breve descrição dos ensaios, o tipo de ensaio realizado e a quantidade de amostras ensaiadas. 
Tabela 4.3: Síntese do programa experimental.

\begin{tabular}{|c|c|c|c|}
\hline \multicolumn{4}{|c|}{ Caracterização do compósito } \\
\hline Traços & Compressão & Tração & Módulo de Elasticidade \\
\hline V0PP5L30 & \multirow{6}{*}{$\begin{array}{l}4 \text { corpos-de-prova } \\
\text { cilíndricos de } 50 \mathrm{~mm} \text { de } \\
\text { diâmetro por } 100 \mathrm{~mm} \text { de } \\
\text { altura para cada traço }\end{array}$} & \multirow{6}{*}{$\begin{array}{l}4 \text { corpos-de-prova } \\
\text { cilíndricos de } 50 \mathrm{~mm} \text { de } \\
\text { diâmetro por } 100 \mathrm{~mm} \text { de } \\
\text { altura para cada traço }\end{array}$} & \multirow{6}{*}{$\begin{array}{c}3 \text { corpos-de-prova cilíndricos } \\
\text { de } 50 \mathrm{~mm} \text { de diâmetro por } \\
\text { 100mm de altura para cada } \\
\text { traço }\end{array}$} \\
\hline V5PP4,5L30 & & & \\
\hline V10PP4L30 & & & \\
\hline V15PP3,5L30 & & & \\
\hline V20PP3L30 & & & \\
\hline V25PP2,5L30 & & & \\
\hline Total de amostras & 24 corpos-de-prova & 24 corpos-de-prova & 18 corpos-de-prova \\
\hline \multicolumn{4}{|c|}{ Ensaio de força distribuída } \\
\hline \multicolumn{2}{|c|}{ Carregamento monotônico - compressão } & \multicolumn{2}{|c|}{ Carregamento cíclico - compressão } \\
\hline V5PP4,5L30 & \multirow{5}{*}{$\begin{array}{c}2 \text { placas de } 150 \mathrm{~mm} x \\
150 \mathrm{~mm} \text { com espessura } \\
\text { de } 10 \mathrm{~mm} \text { para cada traço }\end{array}$} & V5PP4,5L30 & \multirow{5}{*}{$\begin{array}{l}\text { Aplicação de } 50 \text { e } 300 \text { ciclos } \\
\text { de carga em almofadas de } \\
\text { 10mm e } 20 \mathrm{~mm} \text { de espessura* }\end{array}$} \\
\hline V10PP4L30 & & V10PP4L30 & \\
\hline V15PP3,5L30 & & V15PP3,5L30 & \\
\hline V20PP3L30 & & - & \\
\hline V25PP2,5L30 & & - & \\
\hline Total de amostras & 10 almofadas & Total de amostras & 9 almofadas \\
\hline \multicolumn{4}{|c|}{ Aplicação de pressões com intensidades de 2,5MPa, 5,0MPa, 10,0MPa e 20,0MPa. } \\
\hline \multicolumn{4}{|c|}{ Ensaio de força concentrada } \\
\hline Traços & & Compressão & \\
\hline V0PP5L30 & \multirow{6}{*}{\multicolumn{3}{|c|}{$\begin{array}{l}10 \text { tiras de } 25 \mathrm{~mm} \times 150 \mathrm{~mm} \text { cortadas das almofadas do compósito e ensaiadas com } \\
\text { auxílio de dispositivo metálico para aplicação de força concentrada para cada traçc }\end{array}$}} \\
\hline V5PP4,5L30 & & & \\
\hline V10PP4L30 & & & \\
\hline V15PP3,5L30 & & & \\
\hline V20PP3L30 & & & \\
\hline V25PP2,5L30 & & & \\
\hline Total de amostras & \multicolumn{3}{|c|}{60 tiras de almofada } \\
\hline \multicolumn{4}{|c|}{ Ensaio de ligação de blocos } \\
\hline Traço da almofada & \multicolumn{3}{|c|}{ Compressão com rugosidade variável } \\
\hline V10PP4L30 & \multicolumn{3}{|c|}{$\begin{array}{l}9 \text { conjuntos de blocos, } 4 \text { peças para cada conjunto, que simulavam peças de } \\
\text { concreto moldado no local e concreto pré-moldado com e sem presença da } \\
\text { almofada nas ligações e com rugosidades de } 0,75 \mathrm{~mm}, 1,00 \mathrm{~mm} \text { e } 1,5 \mathrm{~mm}\end{array}$} \\
\hline Total de amostras & \multicolumn{3}{|c|}{36 blocos e 16 almofadas } \\
\hline \multicolumn{4}{|c|}{ Ensaio de rotação de apoio } \\
\hline Traços & \multicolumn{3}{|c|}{ Compressão excêntrica } \\
\hline V5PP4,5L30 & \multirow{3}{*}{\multicolumn{3}{|c|}{$\begin{array}{c}\text { aplicação cargas excêntricas gerando pressões de até } 20 \mathrm{MPa} \text { em almofadas de } \\
\text { 150mm de lado, sendo } 2 \text { almofadas de } 10 \mathrm{~mm} \text { de } 2 \text { almofadas de } 20 \mathrm{~mm} \text { de } \\
\text { espessura para cada traço }\end{array}$}} \\
\hline V10PP4L30 & & & \\
\hline V15PP3,5L30 & & & \\
\hline Total de amostras & \multicolumn{3}{|c|}{12 almofadas } \\
\hline \multicolumn{4}{|c|}{ Ensaio tenacidade ao fraturamento } \\
\hline Traços & \multicolumn{3}{|c|}{ Flexão em 3 pontos } \\
\hline V10PP4L30 & \multicolumn{3}{|c|}{$\begin{array}{c}5 \text { vigas de } 300,0 \mathrm{~mm} \text { de vão livre com altura de } 75,0 \mathrm{~mm} \text { e largura de } 37,5 \mathrm{~mm} \text { com } \\
\text { um entalhe de } 20,0 \mathrm{~mm} \text { no meio do vão }\end{array}$} \\
\hline Total de amostras & & 5 vigas & \\
\hline
\end{tabular}





\section{Análise de Resultados}

\subsection{Preliminares}

Neste capítulo serão apresentados todos os resultados dos ensaios realizados para a caracterização do compósito e também das almofadas produzidas com o compósito. A análise dos pontos importantes de cada ensaio será abordada no decorrer da apresentação dos mesmos e, assim, as discussões acerca das características obtidas serão tratadas gradativamente. O objetivo principal deste capítulo é a realização de uma análise crítica das características do compósito para sua utilização na produção das almofadas que servirão ao uso como elemento de apoio.

\subsection{Resistências e módulo de deformação}

\subsubsection{Resistência à compressão}

Os ensaios de compressão foram realizados em seis dosagens diferentes do compósito, sendo que, os resultados dessa resistência foram preponderantes na escolha dos traços que passariam por ensaios mais específicos e também na determinação do traço básico a ser utilizado na produção de almofadas para elemento de apoio. Na Tabela 5.1 são apresentados os resultados para as diferentes dosagens estudadas. 
Tabela 5.1: Resultados do ensaio de compressão simples para os traços estudados.

\begin{tabular}{cc}
\hline Traço & Tensão de Ruptura (MPa) \\
\hline V0PP5L30 & 43,00 \\
V5PP4,5L30 & 36,30 \\
V10PP4L30 & 34,90 \\
V15PP3,5L30 & 29,40 \\
V20PP3L30 & 24,40 \\
V25PP2,5L30 & 20,20 \\
\hline
\end{tabular}

Para facilitar a visualização dos resultados, na figura 5.1 é apresentado o gráfico de valores comparativos para este traço.

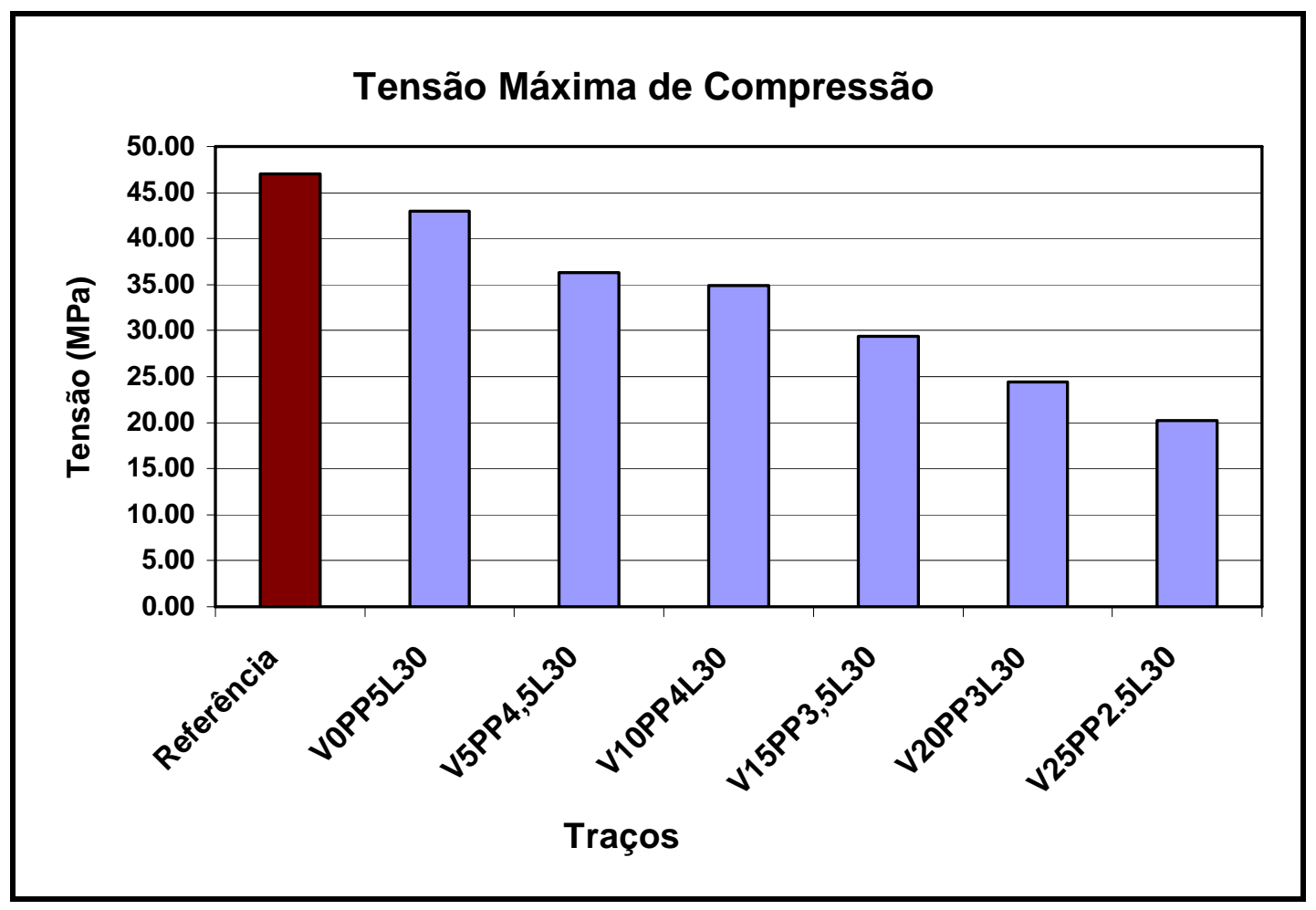

Figura 5.1: Gráfico comparativo para o ensaio de compressão simples.

Os resultados obtidos nesta pesquisa se mostram com a mesma tendência obtida pela pesquisa realizada por MONTEDOR (2004), onde a diminuição da quantidade de fibra e o aumento da quantidade de vermiculita, para amostras com valores constantes na quantidade de látex, apresentam uma diminuição no seu valor de resistência à 
compressão. Nos resultados obtidos na pesquisa anterior, quando da análise das características do compósito para cada material incorporado, tinha-se um aumento na resistência à compressão com o aumento na quantidade de fibra incorporada, diminuição da resistência com o aumento da porcentagem de vermiculita e, um aumento na resistência para valores de incorporação de látex até a ordem de 30\%, a partir desse valor ocorria uma queda nos valores da mesma.

Para o compósito estudado, apesar da mudança do tipo de fibra estudada, onde anteriormente foram utilizadas fibras de PVA e de Vidro e, agora está sendo utilizada fibra de Polipropileno, observa-se que essa tendência mantém-se apesar da diferença no tipo da fibra.

Para a confecção de almofadas a serem utilizadas como aparelho de apoio de elementos de concreto pré-moldado, o compósito necessita de certa resistência e níveis de deformabilidade condizentes à sua aplicação.

Utilizando resultados da pesquisa de MONTEDOR (2004), pode-se realizar uma comparação entre valores de resistência de elementos com a mesma quantidade de vermiculita e látex (Figura 5.2). Os valores em laranja são da pesquisa realizada anteriormente e as letras F e VD indicam a quantidade de fibra de PVA e vidro, respectivamente, que foi introduzida no compósito.

Pela análise da Figura 5.2 pode-se verificar que com a introdução da fibra de polipropileno os valores de resistência não sofreram alterações significativas, mostrando que a fibra de polipropileno pode ser utilizada sem a perda de desempenho no comportamento do compósito. Pôde-se introduzir uma quantidade maior da fibra de polipropileno, verificando-se alguns resultados de resistência maior para corpos-deprova moldados com este tipo de fibra.

Na ruptura, estes corpos-de-prova, devido à presença da fibra, não apresentaram ruptura frágil, continuando íntegros ao final do ensaio. Apresentando apenas um esmagamento em suas bases devido ao efeito de confinamento que estes estão submetidos pelos pratos da máquina de ensaios. 


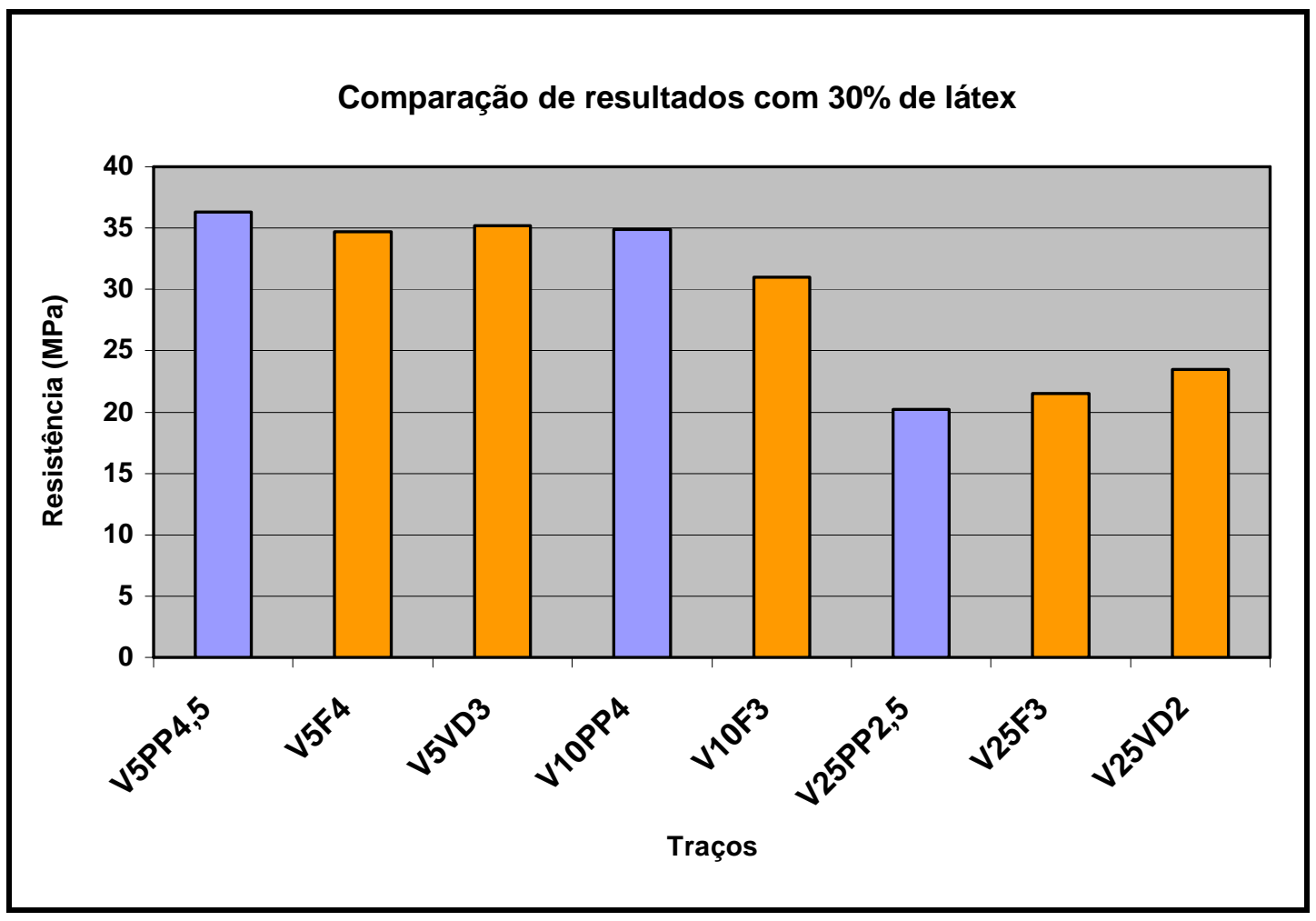

Figura 5.2: Comparação dos resultados de resistência à compressão para $30 \%$ de látex.

\subsubsection{Resistência à tração por compressão diametral}

Para os ensaios de resistência à tração por compressão diametral, também foram estudados seis traços do compósito. Na Tabela 5.2 são apresentados os resultados médios dos ensaios de quatro corpos-de-prova para cada traço.

Tabela 5.2: Resultados do ensaio tração para os traços estudados.

\begin{tabular}{cc}
\hline Traço & Tensão de Ruptura (MPa) \\
\hline V0PP5L30 & 2,87 \\
V5PP4,5L30 & 2,71 \\
V10PP4L30 & 2,66 \\
V15PP3,5L30 & 3,15 \\
V20PP3L30 & 2,36 \\
V25PP2,5L30 & 2,41 \\
\hline
\end{tabular}

Esses valores também foram plotados em forma de gráfico para facilitar a visualização e estão apresentados na Figura 5.3. 


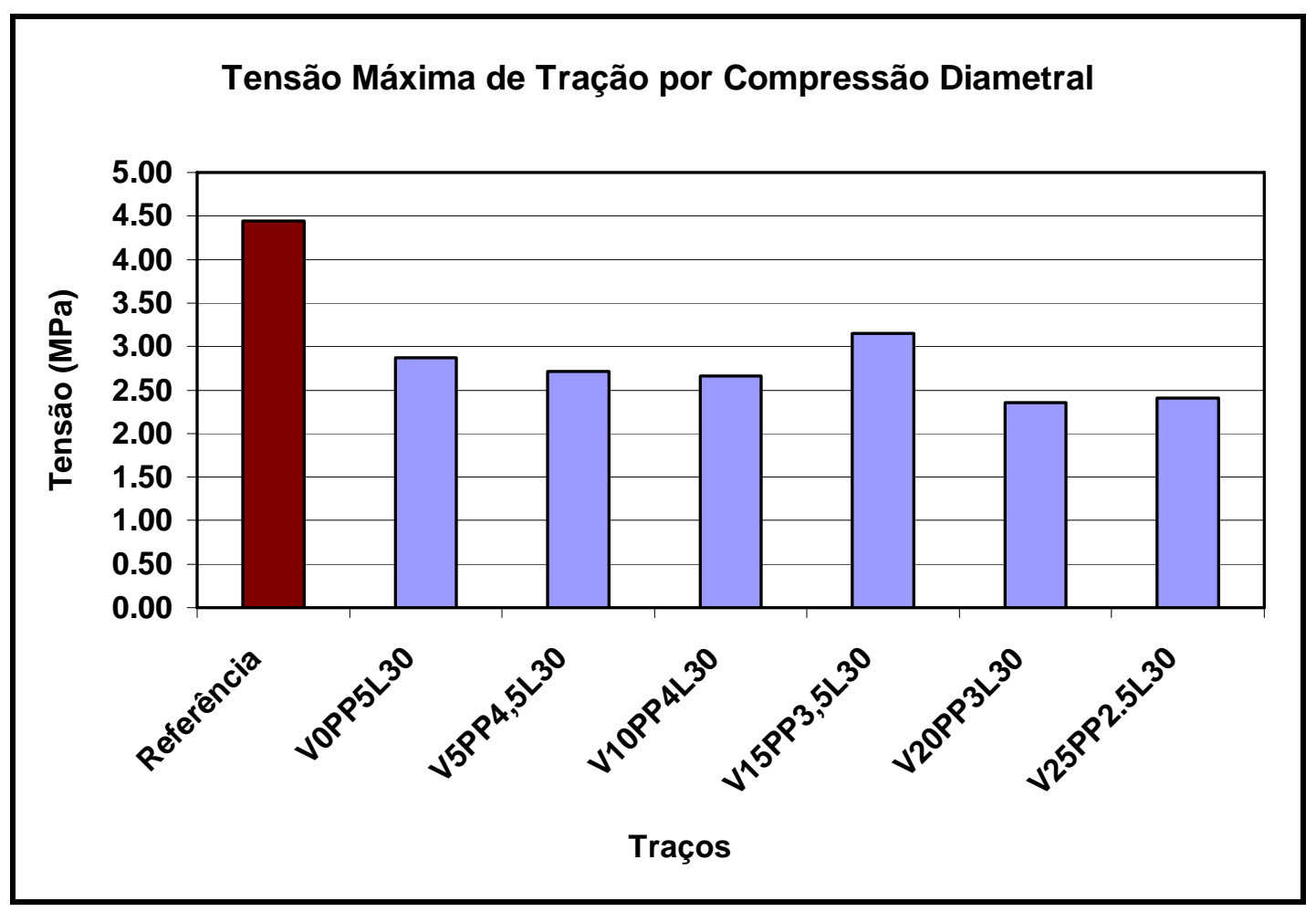

Figura 5.3: Resistência a tração por compressão diametral.

Como pode ser observado na Figura 5.3, com a diminuição da quantidade de fibra e o aumento da quantidade de vermiculita, existe a tendência de diminuição da redução da resistência a tração do compósito. Essa relação também obedece aos resultados obtidos por MONTEDOR (2004). O aumento da resistência por parte do traço V15F3,5L30 não pode ser explicada somente por meio da análise dessa amostragem. No geral, o comportamento do compósito obedece a uma tendência de resultados que já foram devidamente apresentados na pesquisa realizada anteriormente.

Como realizado para a compressão, também são comparados valores de alguns traços desta pesquisa com a pesquisa anterior (Figura 5.4), podendo-se verificar o comportamento de cada tipo de fibra incorporada.

Uma característica importante que cabe ser ressaltada aqui é que, assim como na compressão com a presença da fibra, os corpos-de-prova não apresentam ruptura frágil, apenas sofrendo um leve esmagamento no sentido diametral e rompendo sem separação de superfícies. 
Pode-se ver que para o caso da tração, existe uma diminuição mais acentuada quando se promove a mudança do tipo de fibra incorporada. A fibra de polipropileno, que possui valor de módulo de deformação e resistências menores, apresenta menor desempenho quando comparada às fibras de PVA e vidro neste tipo de ensaio.

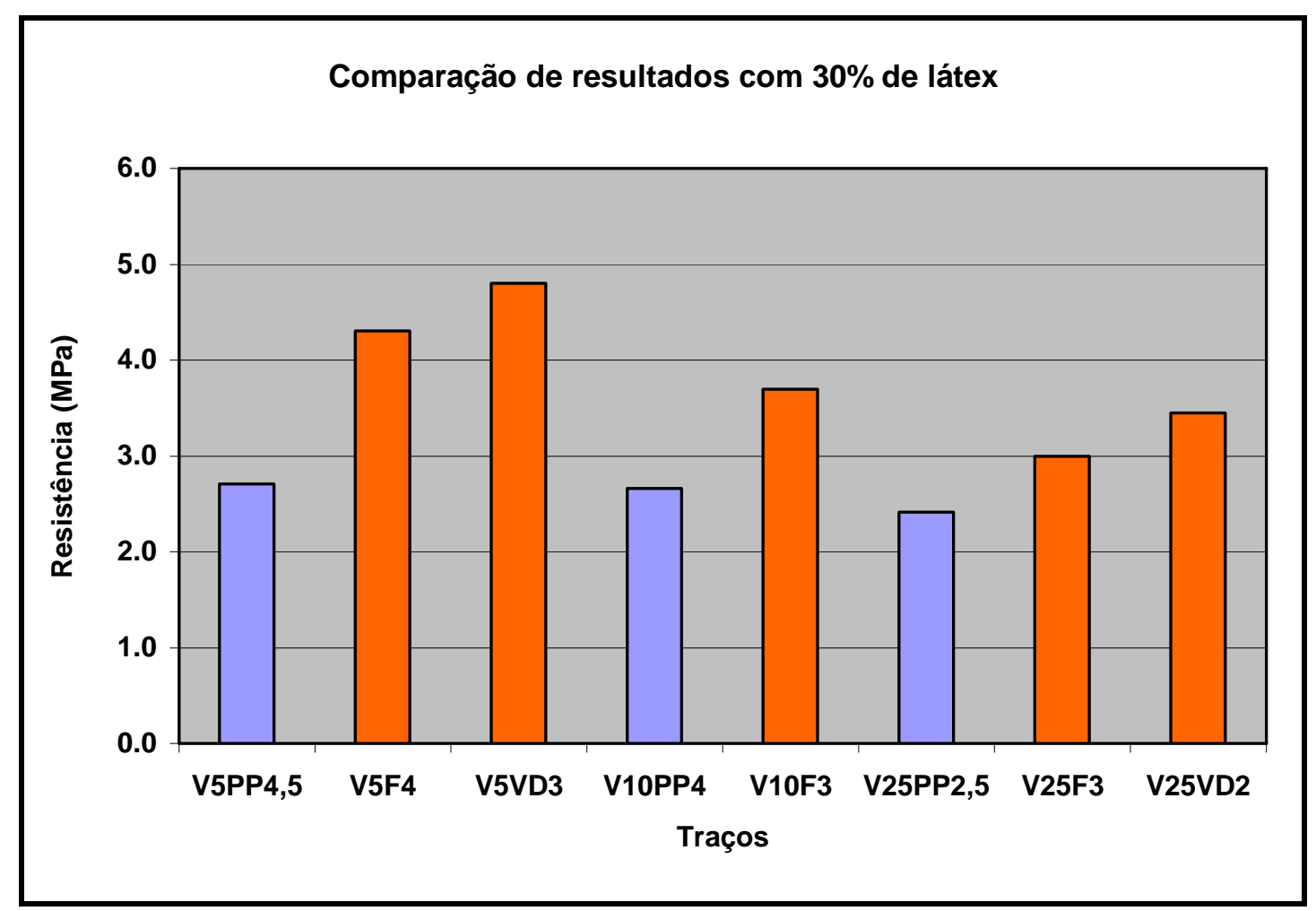

Figura 5.4: Comparação dos resultados de resistência à tração para $30 \%$ de látex.

\subsubsection{Módulo de deformação}

O foco principal deste trabalho foi diminuir o módulo de deformação da argamassa e com isso, torná-la mais deformável e propícia a ser utilizada como elemento de apoio para os elementos de concreto pré-moldado. Logicamente que somente o aumento na deformabilidade do material não seria uma boa condição para justificar sua utilização, mas, nesta fase do estudo, somente esta foi o principal foco de estudo.

Para os resultados de módulo de deformação, foram coletados dados de deslocamento e força aplicada em corpos-de-prova cilíndricos, sendo estes valores posteriormente plotados em um gráfico tensão x deformação para os mesmos, possibilitando assim, a 
obtenção dos valores dos módulos de elasticidade secante e tangente do material (figuras 5.5 e 5.6 ).

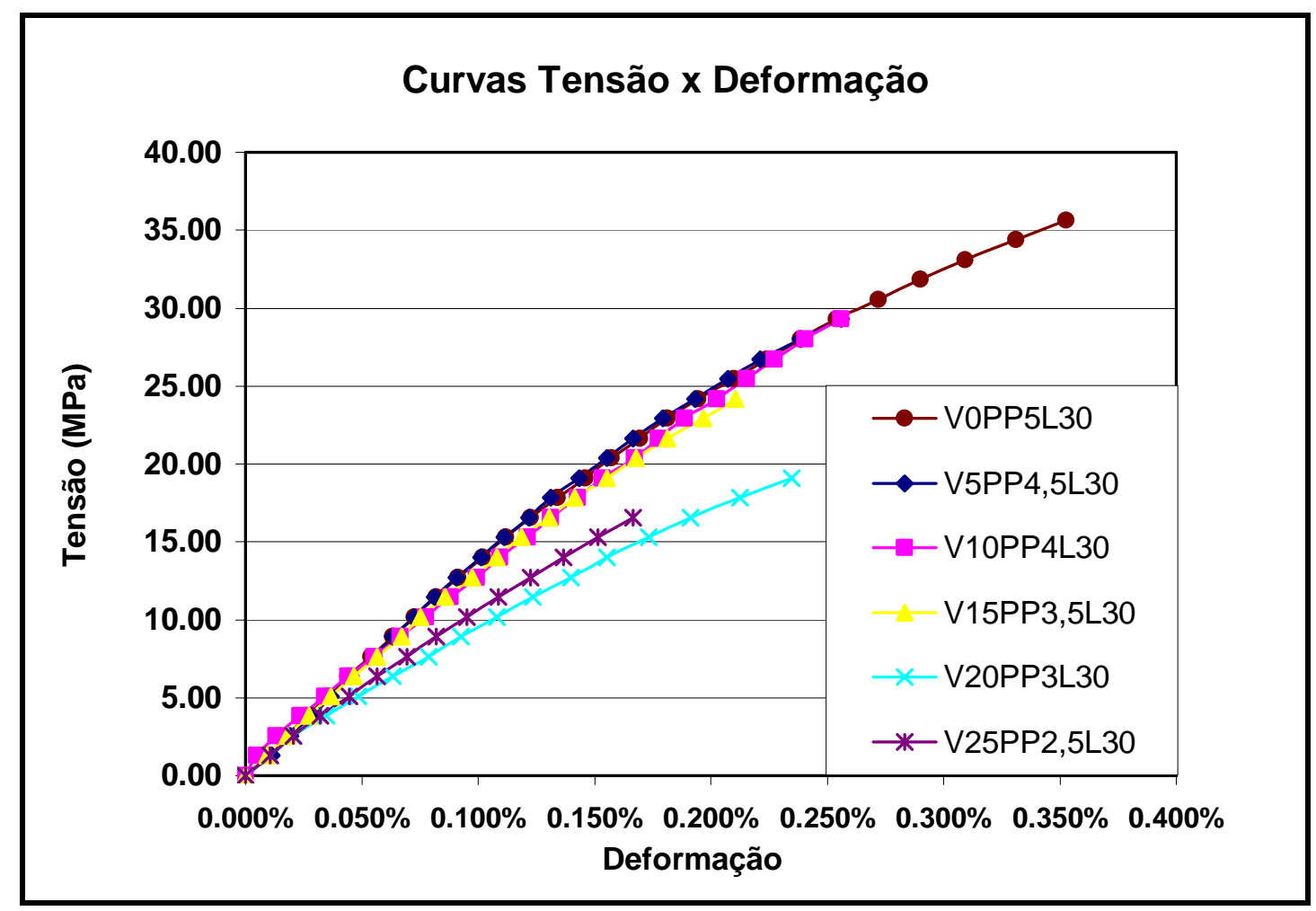

Figura 5.5: Curva tensão x deformação.

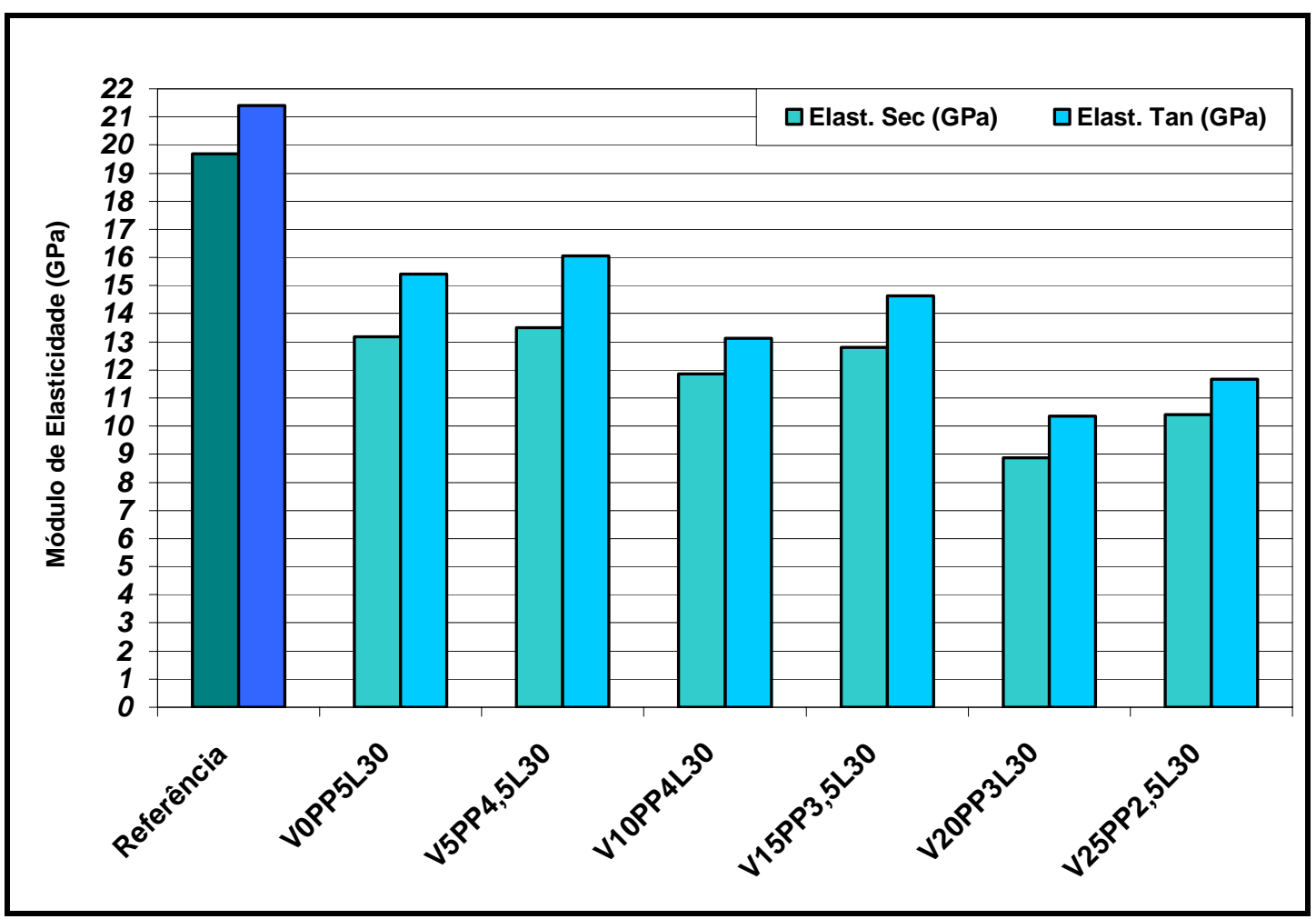

Figura 5.6: Módulo de elasticidade do compósito. 
Pode-se observar a partir da Figura 5.6, que existe uma tendência de aumento no módulo de elasticidade do compósito nos traços com uma menor quantidade de vermiculita e maior de fibra. Os valores dos traços com 15 e $25 \%$ de vermiculita se apresentaram fora do padrão de diminuição apresentado para os outros traços das argamassas, não existindo uma explicação provável somente de posse dos valores dos ensaios realizados.

A incorporação de cada um dos materiais de modificação (vermiculita, fibra ou látex) traz um tipo de mudança nas características finais do compósito. No caso desta pesquisa, partiu-se destas características que cada um dos elementos em separado traria para a almofada e, promoveu-se a junção de todos os componentes, buscando-se no final, o compósito que trouxesse a melhor resposta no conjunto de suas características.

Na Figura 5.7 apresenta-se a comparação entre alguns traços estudados nesta pesquisa e alguns traços com a mesma quantidade de vermiculita e látex estudado por MONTEDOR (2004).

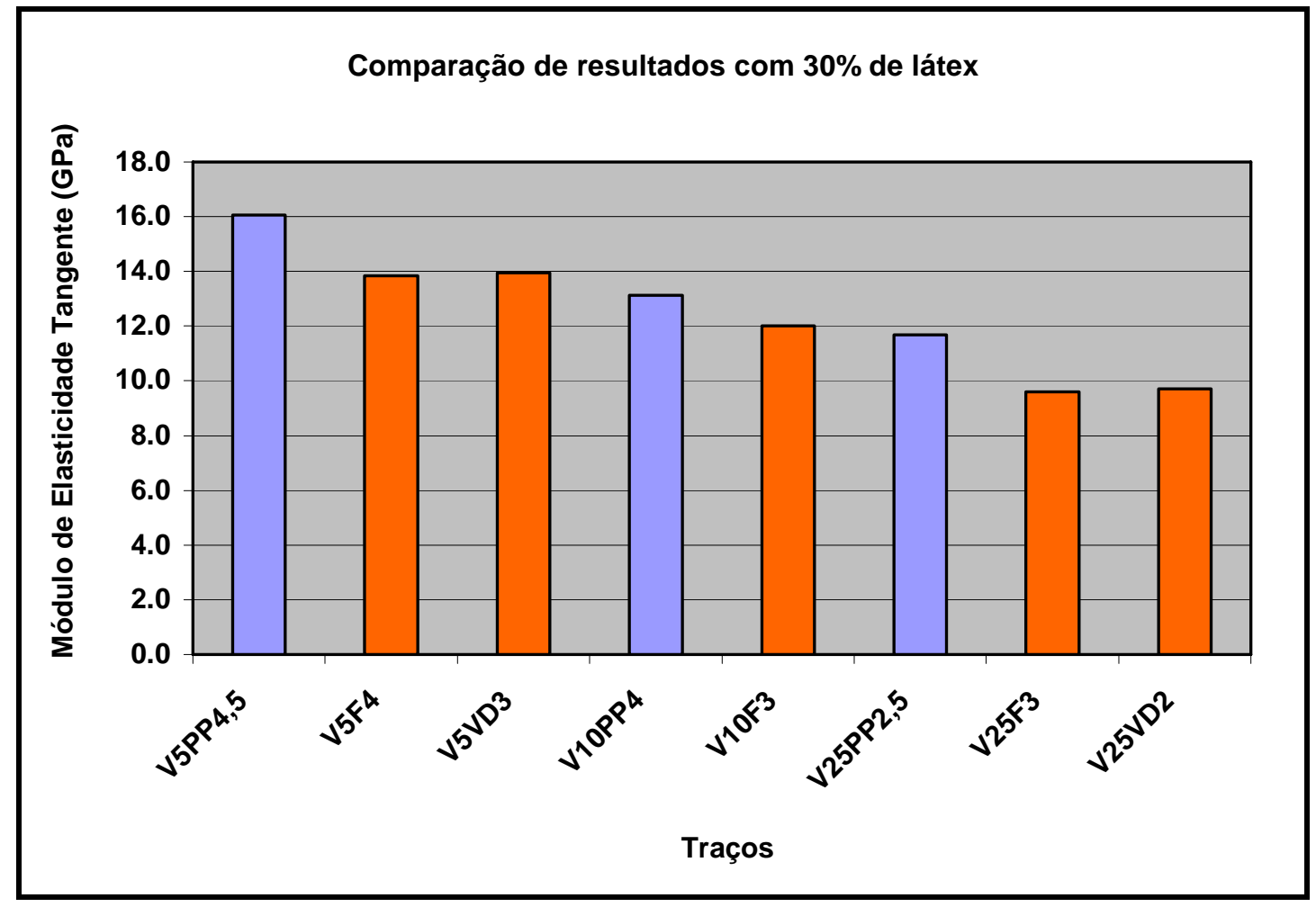

Figura 5.7: Comparação de resultados de módulo de elasticidade. 
Observando-se a Figura 5.7 pode-se ver que com a fibra de polipropileno nos corpos-deprova, os valores do módulo de elasticidade tangente foram maiores que para os corposde-prova na presença de fibras de PVA e vidro. Este fato, isoladamente, não é conclusivo para poder dizer que a utilização de fibras de polipropileno não seria recomendável frente às outras fibras, mesmo porque, os módulos de elasticidade desses traços se apresentaram inferiores aos de uma argamassa convencional de cimento.

Para finalizar o processo de análise, compararam-se os resultados de resistência a compressão com a resistência à tração do material e também resultados do módulo de elasticidade, tanto tangente quanto secante, com os valores de resistência, gerando-se as respectivas relações que estão apresentadas na Tabela 5.3.

Tabela 5.3: Relações entre resistências e módulo de elasticidade.

\begin{tabular}{|c|c|c|c|c|c|c|c|c|}
\hline Traço & $f_{c}(\mathrm{MPa})$ & $f_{t}(\mathrm{MPa})$ & $E_{c i}(\mathrm{GPa})$ & $E_{c s}(\mathrm{GPa})$ & $f_{c} / f_{t}$ & $E_{c i} / f_{c}$ & $E_{c i} / f_{c}{ }^{1 / 2}$ & $E_{c s} / f_{c}^{1 / 2}$ \\
\hline V0F5L30 & 43,00 & 2,87 & 15,4 & 13,2 & 14,98 & 358,37 & 2350 & 2008 \\
V5F4,5L30 & 36,30 & 2,71 & 16,1 & 13,5 & 13,39 & 442,42 & 2666 & 2242 \\
V10F4L30 & 34,90 & 2,66 & 13,1 & 11,9 & 13,12 & 376,22 & 2223 & 2008 \\
V15F3,5L30 & 29,40 & 3,15 & 14,6 & 12,8 & 9,33 & 497,96 & 2700 & 2363 \\
V20F3L30 & 24,40 & 2,36 & 10,4 & 8,90 & 10,34 & 424,18 & 2095 & 1794 \\
V25F2,5L30 & 20,20 & 2,41 & 11,7 & 10,4 & 8,38 & 577,72 & 2597 & 2314 \\
\hline
\end{tabular}

Observando-se os valores da relação de resistências, pode-se visualizar que os valores apresentam-se entre 8 e 15 vezes, não sendo este o indicativo principal do melhor traço a ser utilizado.

A relação de $E_{c i} / f_{c}$ (elasticidade tangente sobre resistência à compressão) foi um indicativo mais claro do desempenho dos traços do compósito. Para tornar mais clara a análise, foi utilizada a relação entre $E_{c i}$ e $E_{c s}$ (elasticidade tangente e secante) sobre $f_{c}^{1 / 2}$ (resistência à compressão elevada ao quadrado) que pode ser comparada à relação de valores de módulo de elasticidade secante e tangente sobre a resistência à compressão prescritos pela NBR-6118/2003 para concretos entre 10 e 50MPa. As relações estão descritas abaixo: 


$$
E_{c i}=5600 \cdot \sqrt{f_{c j}} \rightarrow \frac{E_{c i}}{\sqrt{f_{c j}}}=5600
$$

Sendo:

$E_{c i}=$ Módulo de elasticidade tangente;

$f_{c j}=$ Resistência à compressão do concreto aos $\mathbf{j}$ dias.

Para efeito de projeto, nas verificações em regime elástico da estrutura, tais como, esforços solicitantes e verificação de estados limites de serviço, deve ser utilizado o módulo de elasticidade secante. Portanto a relação fica da seguinte forma:

$$
E_{c s}=0,85.5600 \cdot \sqrt{f_{c k}} \rightarrow \frac{E_{c i}}{\sqrt{f_{c k}}}=4760
$$

Sendo:

$E_{c s}=$ Módulo de elasticidade secante;

$f_{c k}=$ Resistência característica do concreto à compressão.

Estas relações estão apresentadas na forma de gráfico na Figura 5.8 comparando-se os valores dos traços estudados com o concreto, de onde se pode tirar a conclusão que, como necessita-se de um material com grande capacidade de deformação com a maior resistência possível, precisamos do menor valor da relação $\mathrm{E}_{\mathrm{c}} / \mathrm{f}_{\mathrm{c}}^{1 / 2}$.

Pela análise dos resultados podemos ver que dois traços concorrem para serem eleitos os mais adequados a serem utilizados por apresentarem os menores valores de $E_{c} / f_{c}{ }^{1 / 2}$ na Figura 5.8, o traço V10PP4L30 e o V20PP3L30. Como critério de utilização da amostra foi então verificado o valor da resistência à compressão, remetendo-se a utilização do traço V10F4L30. Estes resultados nos mostram a uma tendência de um traço para ser utilizado na confecção das almofadas, um número maior de estudos se faz necessário para que se possa promover com maior grau de certeza a eleição do melhor, dentre os traços estudados, a ser utilizado na confecção das almofadas do compósito. 


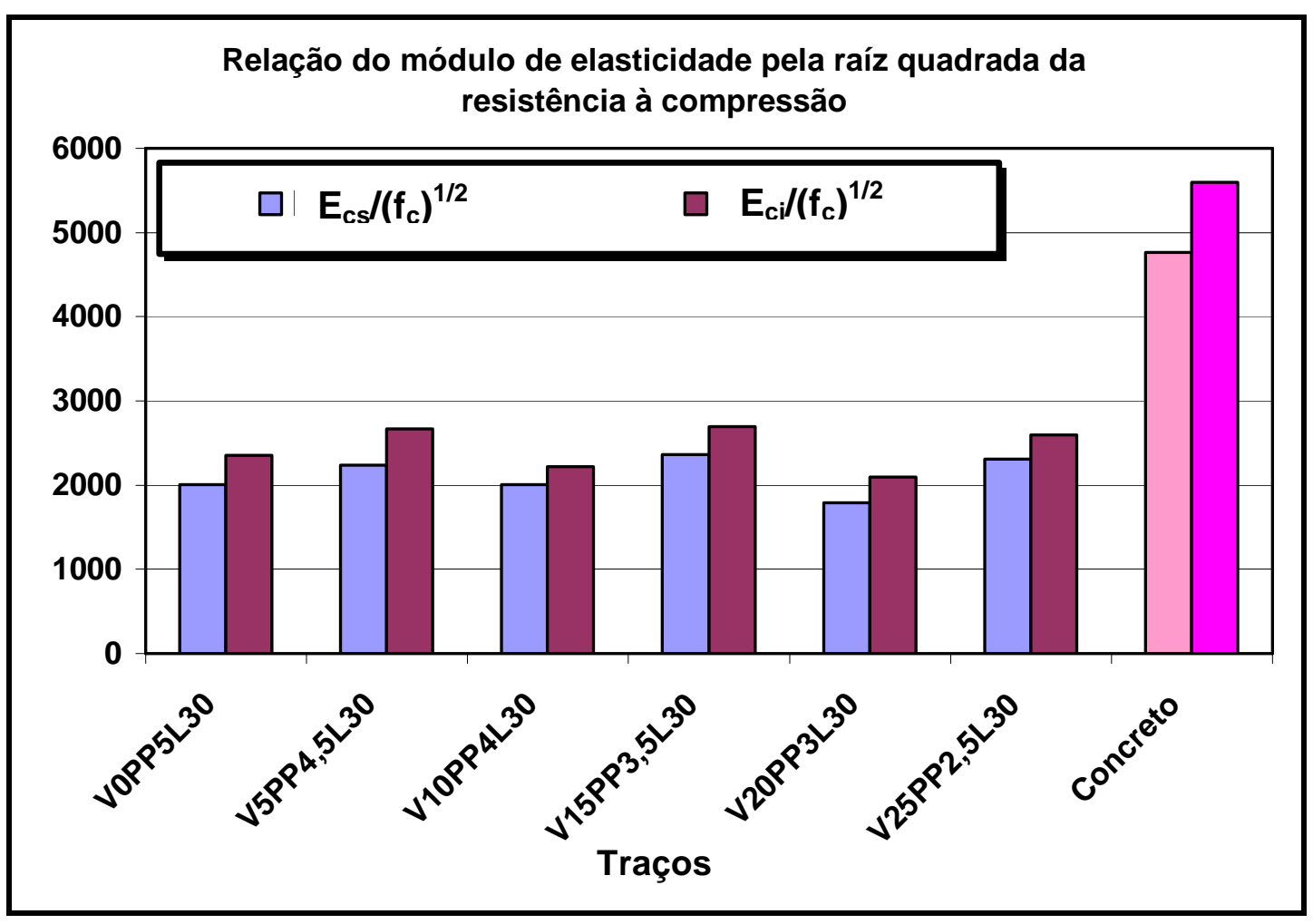

Figura 5.8: Relação entre módulos de elasticidade secante e tangente e resistência a compressão.

\subsection{Ensaios de força distribuída}

\subsubsection{Carregamento Monotônico}

Este ensaio foi realizado visando-se determinar a rigidez de placa, que nada mais é que a relação tensão x deformação das almofadas do compósito e mede a capacidade de deformação elástica do material.

A partir das curvas geradas no ensaio de carregamento monotônico, foi realizada a análise das amostras das almofadas e os resultados foram devidamente tratados. O procedimento para o cálculo da rigidez, cuja simbologia adotada neste trabalho foi a letra R, está apresentado no capítulo 4, no item 4.2. Nesta fase do trabalho foram ensaiadas placas com dimensões de $150 \mathrm{~mm}$ x 150mm de base com espessura de $10 \mathrm{~mm}$. A escolha dessa espessura foi motivada pela pesquisa realizada por MONTEDOR (2004), onde este obteve melhores resultados para alguns ensaios em específico com $10 \mathrm{~mm}$ de espessura das almofadas. 
Na Tabela 5.4 são apresentados os valores de rigidez obtidos para os traços estudados.

Tabela 5.4: Rigidez das placas dos traços estudados.

\begin{tabular}{cccc}
\hline Traço & \multicolumn{2}{c}{ Rigidezes (MPa) } & Rigidez Média \\
& PL1 & PL2 & $($ MPa) \\
\hline V5PP4,5L30 & 412 & 365 & 388 \\
V10PP4L30 & 338 & 364 & 351 \\
V15PP3,5L30 & 293 & 376 & 335 \\
V20PP3L30 & 209 & 192 & 201 \\
V25PP2,5L30 & 321 & 257 & 289 \\
\hline
\end{tabular}

Como pode ser observado na Tabela 5.4, ocorre a diminuição no valor da rigidez com o aumento da quantidade de vermiculita e diminuição da quantidade de fibra. Esta tendência também foi observada na pesquisa anterior, mantendo-se nesta pesquisa, apesar da utilização da fibra de Polipropileno em substituição das fibras de PVA e Vidro.

Para facilitar a visualização dos resultados, os valores de rigidez foram plotados em um gráfico que está apresentado na Figura 5.9.

Como se pode observar, os valores de rigidez das placas apresentaram-se bem menores que os valores do módulo de elasticidade dos corpos-de-prova, denotando-se que estas possuem uma maior capacidade de deformação e, conseqüente, melhor transmissão das tensões na região das ligações entre os elementos pré-moldados de concreto. Na Tabela 5.5 e na Figura 5.10 são apresentados os valores da relação entre os valores do módulo de elasticidade dos corpos-de-prova com a rigidez das almofadas. 


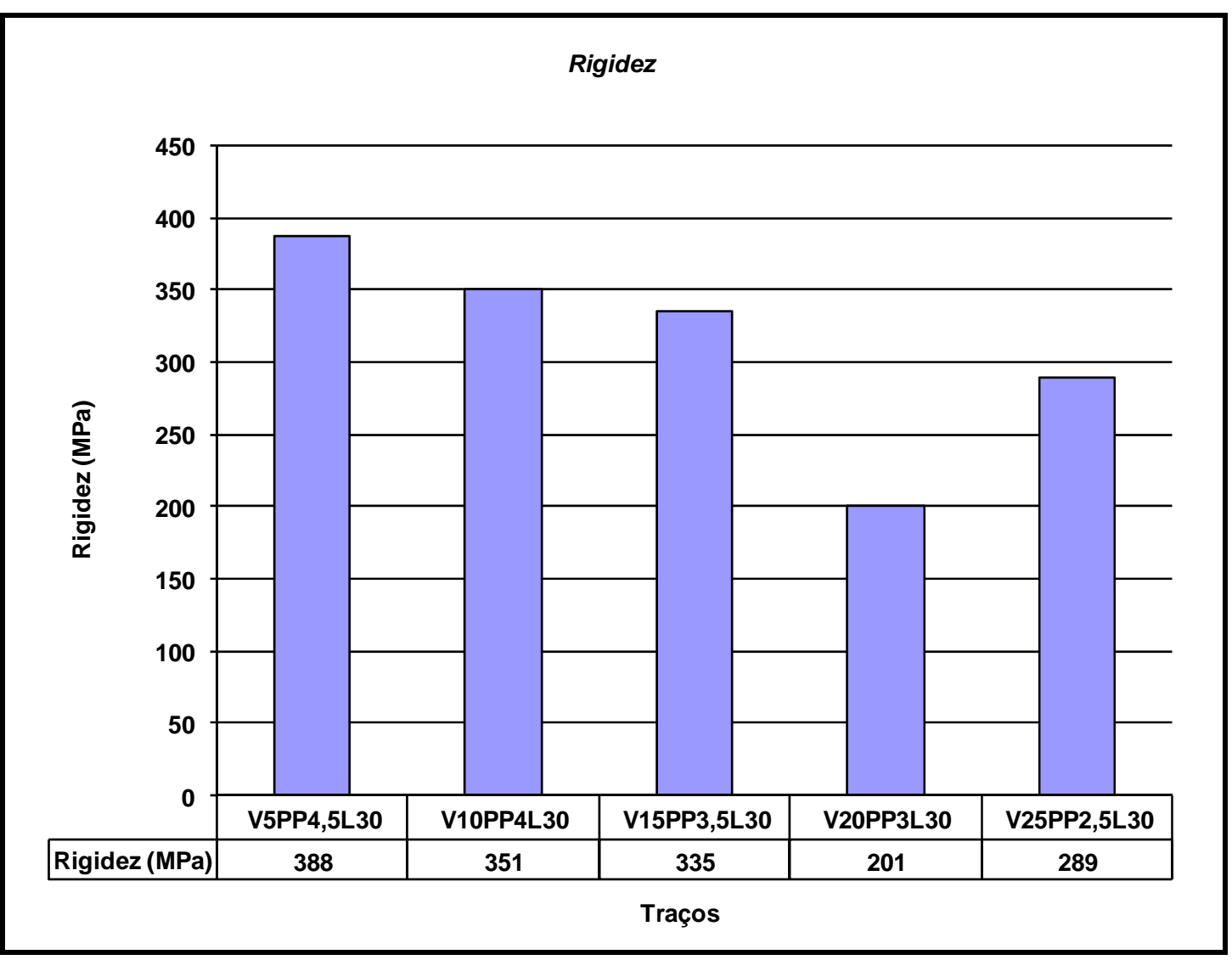

Figura 5.9: Rigidez das placas.

Tabela 5.5: Relações entre módulo de elasticidade e rigidez.

\begin{tabular}{|cccccc|}
\hline Traço & $E_{c i}(\mathrm{GPa})$ & $E_{c s}(\mathrm{GPa})$ & $R(\mathrm{MPa})$ & $E_{c i} / R$ & $E_{c s} / R$ \\
\hline V5PP4,5L30 & 16,1 & 13,5 & 388 & 41,4 & 34,8 \\
V10PP4L30 & 13,1 & 11,9 & 351 & 37,4 & 33,8 \\
V15PP3,5L30 & 14,6 & 12,8 & 335 & 43,7 & 38,2 \\
V20PP3L30 & 10,4 & $\mathbf{8 , 9 0}$ & 201 & 51,5 & 44,1 \\
V25PP2,5L30 & 11,7 & 10,4 & 289 & 40,4 & 36,0 \\
\hline
\end{tabular}




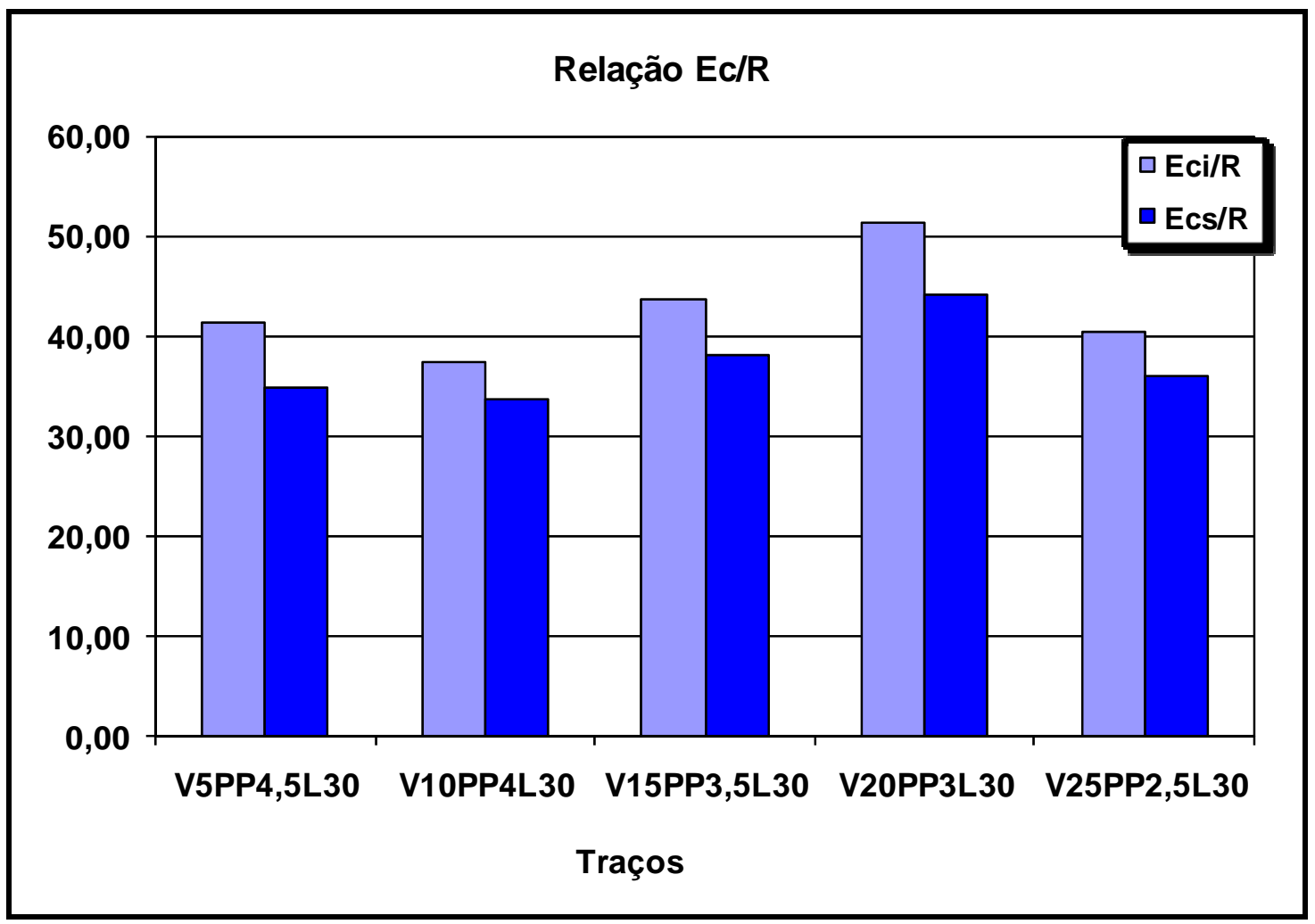

Figura 5.10: Relação entre Módulo de deformação e rigidez das placas.

Com base nestes resultados pode-se verificar uma diminuição da ordem de 35 vezes para o módulo de elasticidade em relação a rigidez das almofadas do compósito. Percebe-se que as almofadas produzidas com o compósito possuem uma capacidade de deformação grande, se comparada aos corpos-de-prova do mesmo compósito e de concreto.

Para poder mostrar a capacidade de deformação dessas almofadas serão apresentados os resultados da rigidez do compósito com a rigidez de almofadas de neoprene e almofadas estudadas de argamassa com o mesmo teor de vermiculita e látex, mas com fibras diferentes, ensaiadas por MONTEDOR (2004), com os mesmos 150mm de lado com 10mm de espessura (Figura. 5.11). 


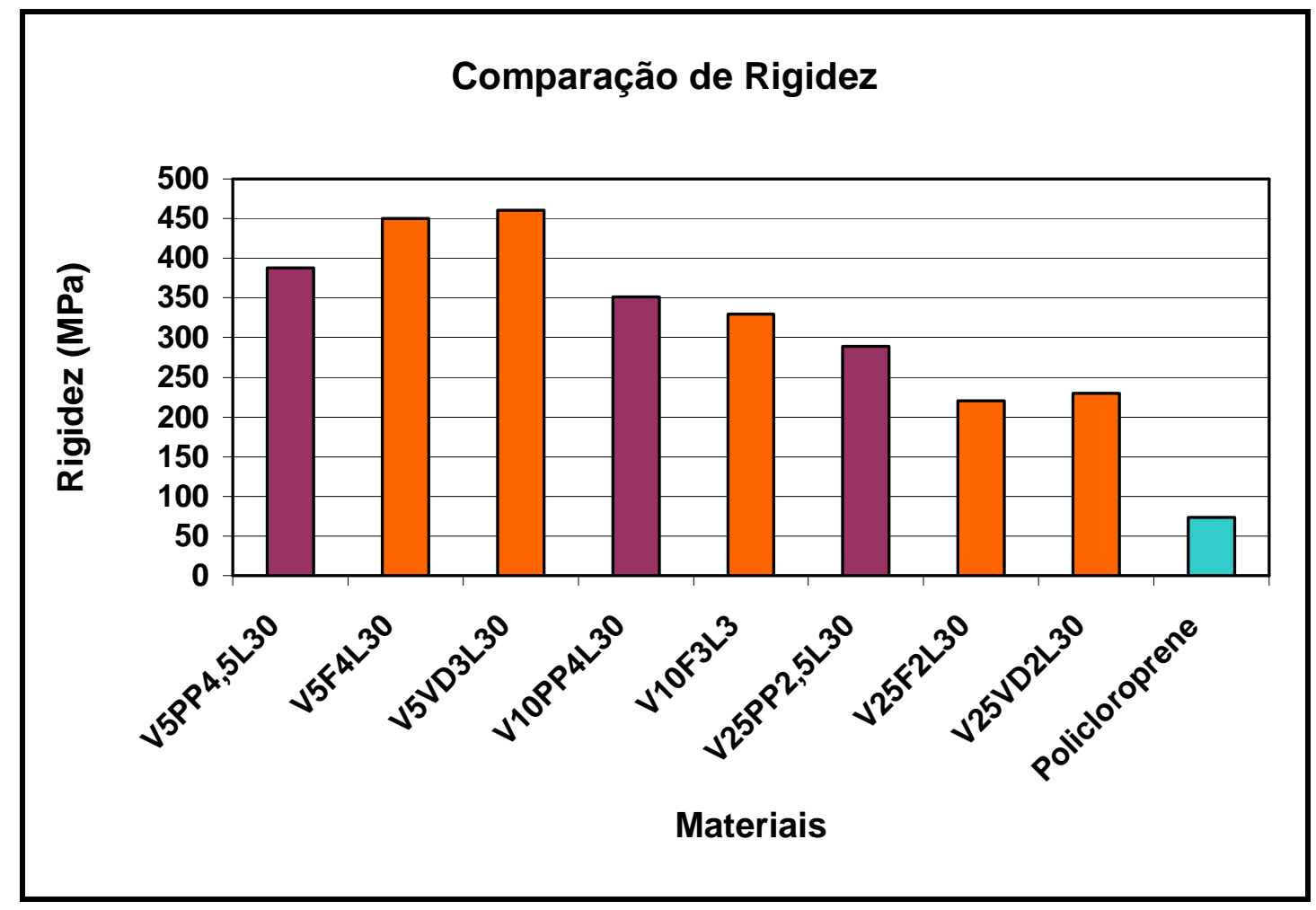

Figura 5.11: Comparação das rigidezes de almofadas do compósito e almofada de neoprene.

Observando-se a Figura 5.11 pode-se verificar que a rigidez das almofadas apresentamse da ordem de 3 a 6 vezes maiores que a rigidez do neoprene e com valores menores que apresentados para argamassas comuns de cimento. A rigidez das almofadas com os diferentes tipos de fibras se apresentam-se com valores próximos, podendo-se efetuar a troca da fibra de PVA e vidro por fibra de polipropileno, que possui custo menor, na produção das almofadas.

\subsubsection{Carregamento cíclico}

A partir da verificação dos baixos valores apresentados de rigidez das almofadas do compósito e, já se tendo ciência da potencialidade da aplicação do material como elemento de apoio, partiu-se para a análise da evolução da rigidez das placas com a aplicação de ciclos de carga e descarga nas almofadas.

Esta situação seria algo mais próximo da situação de atuação do compósito na prática, pois, este estaria sendo utilizado em situações de serviço onde os carregamentos não 
necessariamente estariam presentes o tempo todo, mas sim, se apresentariam com certa variabilidade e repetições cíclicas.

Para tanto, pensou-se em aplicar nas almofadas do compósito, tensões de contato com valores que pudessem representar uma gama de situações as quais o compósito estaria sendo submetido. Na Tabela 5.6 estão apresentados os traços ensaiados bem como as tensões utilizadas e o número de ciclos de carga a que estes foram submetidos para verificação da evolução da rigidez.

Tabela 5.6: Traços estudados nos ensaios de carregamento cíclicos.

\begin{tabular}{|c|c|c|c|c|}
\hline & \multicolumn{3}{|c|}{ TRAÇOS } & \\
\hline Tensão (MPa) & V5PP4,5L30 & V10PP4L30 & V15PP3,4L30 & \\
\hline 2,0 & \multirow{4}{*}{50 ciclos } & \multirow{4}{*}{50 ciclos } & \multirow{4}{*}{50 ciclos } & \multirow{4}{*}{$1^{-}$fase } \\
\hline 5,0 & & & & \\
\hline 10,0 & & & & \\
\hline 20,0 & & & & \\
\hline 2,0 & \multirow{4}{*}{300 ciclos } & \multirow{4}{*}{300 ciclos } & \multirow{4}{*}{300 ciclos } & \multirow{4}{*}{$2^{-}$fase } \\
\hline 5,0 & & & & \\
\hline 10,0 & & & & \\
\hline 20,0 & & & & \\
\hline
\end{tabular}

Os ensaios foram realizados em placas de $150 \mathrm{~mm}$ x $150 \mathrm{~mm}$ e espessura de $10 \mathrm{~mm}$ e foram divididos em duas fases. Na primeira fase dos estudos, para cada tensão de contato calculada e apresentada na Tabela 5.6, foram aplicados 50 ciclos de carregamento, totalizando 200 ciclos para cada almofada do compósito. Na segunda fase, o número de ciclos para cada pressão foi aumentado de 50 para 300, totalizando 1200 ciclos para cada almofada.

A seguir, nas figuras 5.12, 5.13 e 5.14, serão apresentados os gráficos obtidos para cada um dos traços da Tabela 5.6 na primeira fase do estudo. Foram ensaiadas 2 almofadas para cada um dos traços nessa primeira fase de estudos. Nas figuras serão ressaltados os primeiros e os últimos ciclos de carga para cada uma das pressões em cada almofada. 


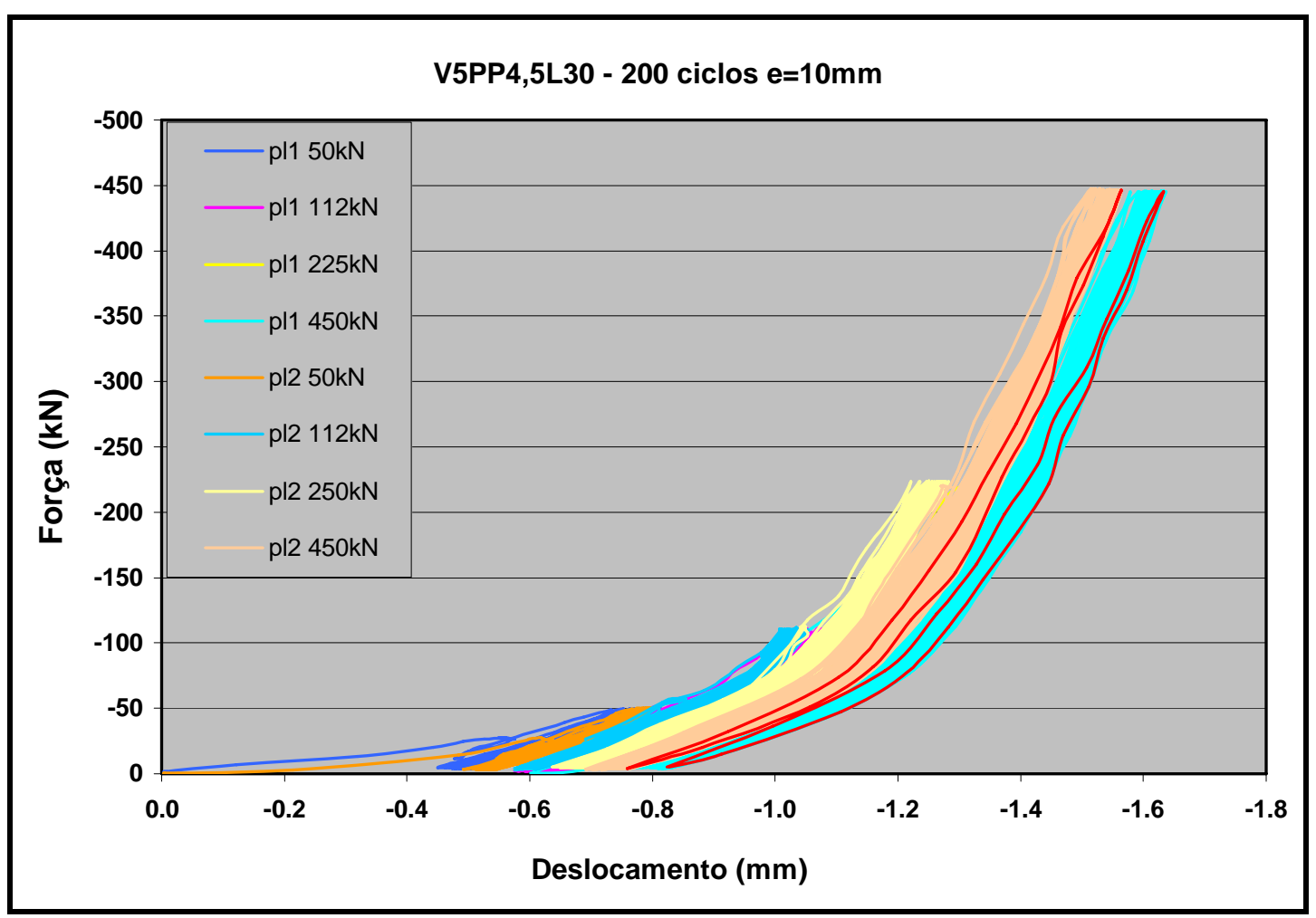

Figura 5.12: Almofadas do traço V5PP4,5L30 com 200 ciclos de carregamento.

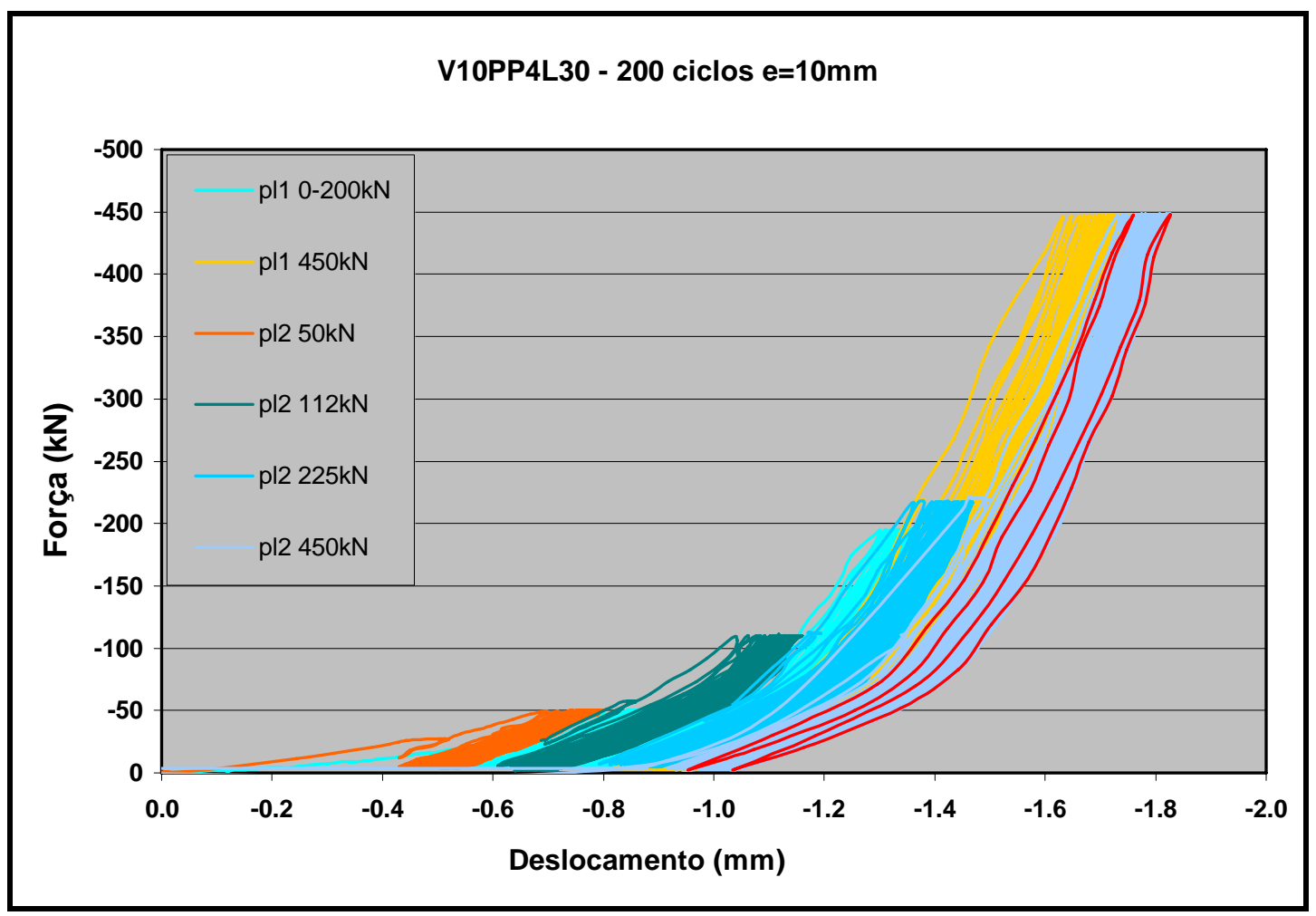

Figura 5.13: Almofadas do traço V10PP4L30 com 200 ciclos de carregamento. 


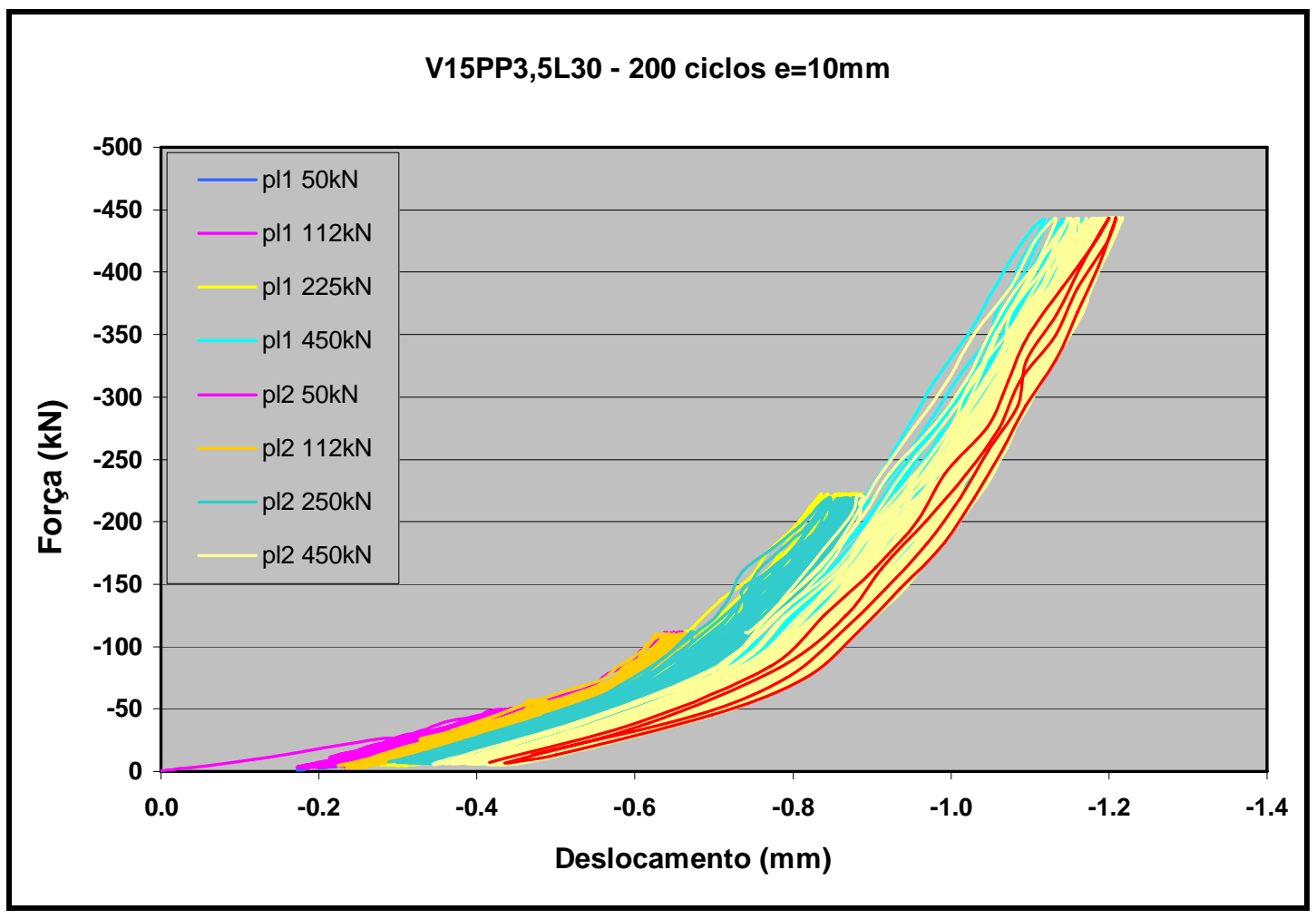

Figura 5.14: Almofadas do traço V15PP3,5L30 com 200 ciclos de carregamento.

Observando-se as figuras, pode-se visualizar o padrão de evolução da rigidez das almofadas, sendo que, a não ser por uma deformação plástica devido ao carregamento, a cada ciclo de carga o comportamento das deformações se mantém em um padrão constante, não sofrendo grandes variações. Nos traços das figuras 5.12 e 5.13 observa-se uma deformação inicial maior que o traço da Figura 5.14. Isto se deve a um problema no ajuste inicial da máquina de ensaios no momento do início do carregamento, onde esta almofada passou por um ciclo de carregamento de $50 \mathrm{kN}$. Após esse ciclo, observou-se que os valores não haviam sido calibrados e zerados antes do início da aquisição dos dados do ensaio, provocando a interrupção deste primeiro ciclo de carregamento e iniciando o ensaio novamente. Isto provocou uma acomodação inicial na superfície da almofada que justifica essa menor deformação no momento do reinício do ensaio.

O que se pode obter como positivo dessa interrupção do ensaio foi que, mesmo após um ciclo de acomodação das irregularidades da superfície da almofada pelo carregamento, a rigidez apresentou um padrão coerente e conciso durante a evolução dos ciclos de carga. 
Os valores em vermelho são do último ciclo de carga para cada almofada, podendo-se visualizar que as rigidezes estão dentro de uma região na qual não ocorre evolução dos afundamentos nas almofadas. A partir de certa acomodação inicial, os ciclos de carga e descarga se apresentam comportados, sem evolução da deterioração da rigidez da almofada, denotando a capacidade resiliente do material.

As almofadas utilizadas, após o ensaio, não apresentaram problemas quanto a coesão e estabilidade, evidenciando somente o esmagamento das imperfeições superficiais provenientes do seu processo de moldagem (Figura 5.15) e algumas pequenas fissuras nas faces de borda das almofadas.

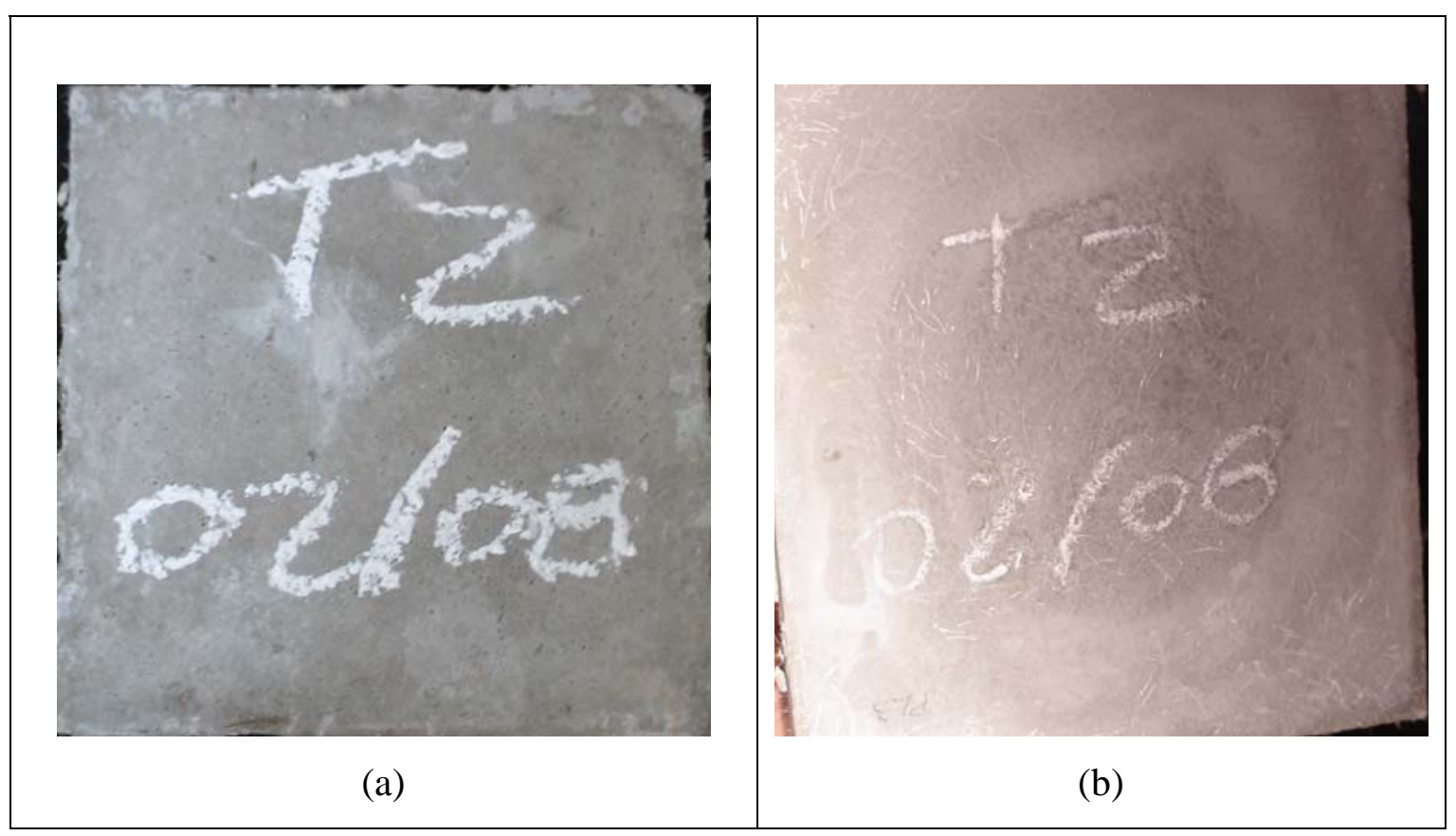

Figura 5.15: (a) Almofadas do traço V10PP4L30 antes do ensaio (b) almofada do traço V10PP4L30 após o ensaio.

Após a realização dessa primeira fase de estudos, surgiu a necessidade de promover um número maior de ciclos para verificar se a tendência da evolução das rigidezes se manteria com o mesmo padrão apresentado. Por isso realizou-se ensaios almofadas do compósito com 1200 ciclos de carregamento, 300 para cada pressão de contato, mas agora em somente uma amostra de almofada do compósito. 
Foram coletados muitos dados para cada traço, tornando a visualização dos resultados mais confusa ainda do que na primeira fase de estudos, então na apresentação destes resultados resolveu-se apresentar somente os valores do ciclo inicial das cargas, um ciclo intermediário e o ciclo final para cada pressão. Nas figuras 5.16, 5.17 e 5.18 são apresentados os gráficos de cada almofada.

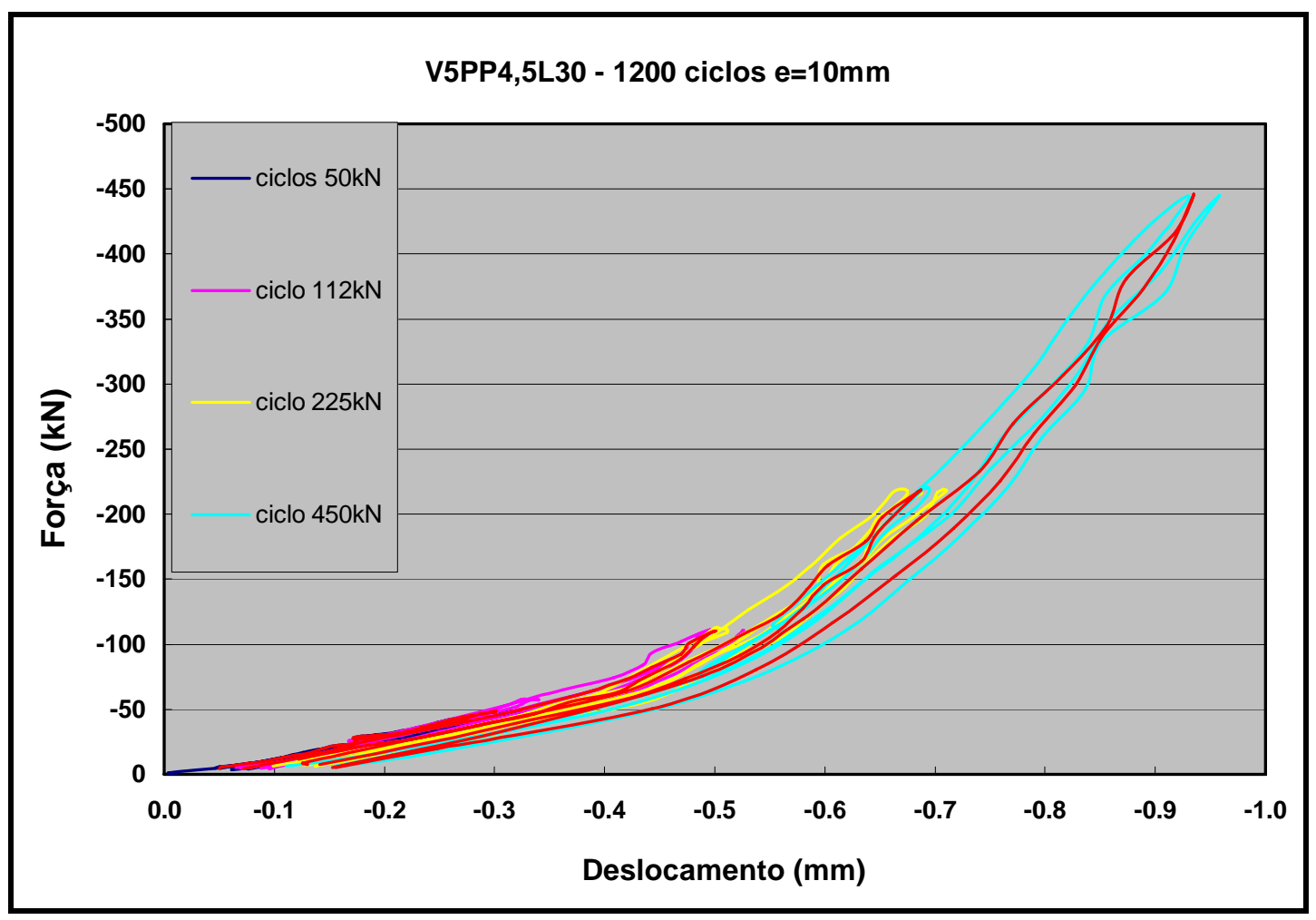

Figura 5.16: Almofada do traço V5PP4,5L30 com 1200 ciclos de carregamento.

Os resultados apresentaram-se consistentes assim como na primeira fase do estudo, sendo que, a rigidez manteve com a mesma tendência de estabilização em torno de um valor após a fase de acomodação das deformações superficiais da almofada. Em vermelho nos gráficos estão apresentados os últimos ciclos de cada pressão de contato. Observa-se que, o último ciclo de carregamento se apresenta em uma situação intermediária em cada etapa de carga, evidenciando que após a acomodação das deformações a rigidez tende a um ponto de equilíbrio não sofrendo maiores modificações. 


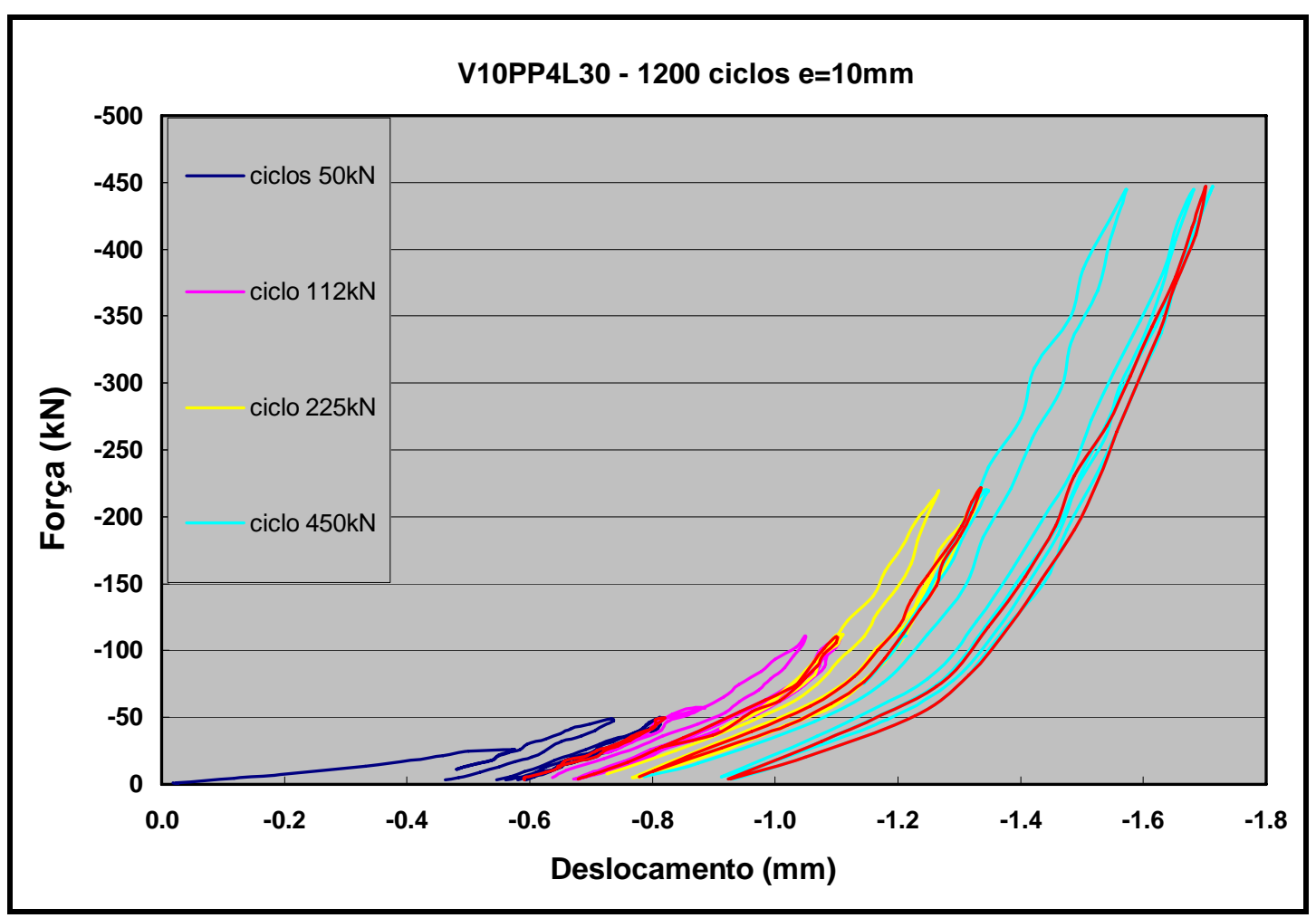

Figura 5.17: Almofada do traço V10PP4L30 com 1200 ciclos de carregamento.

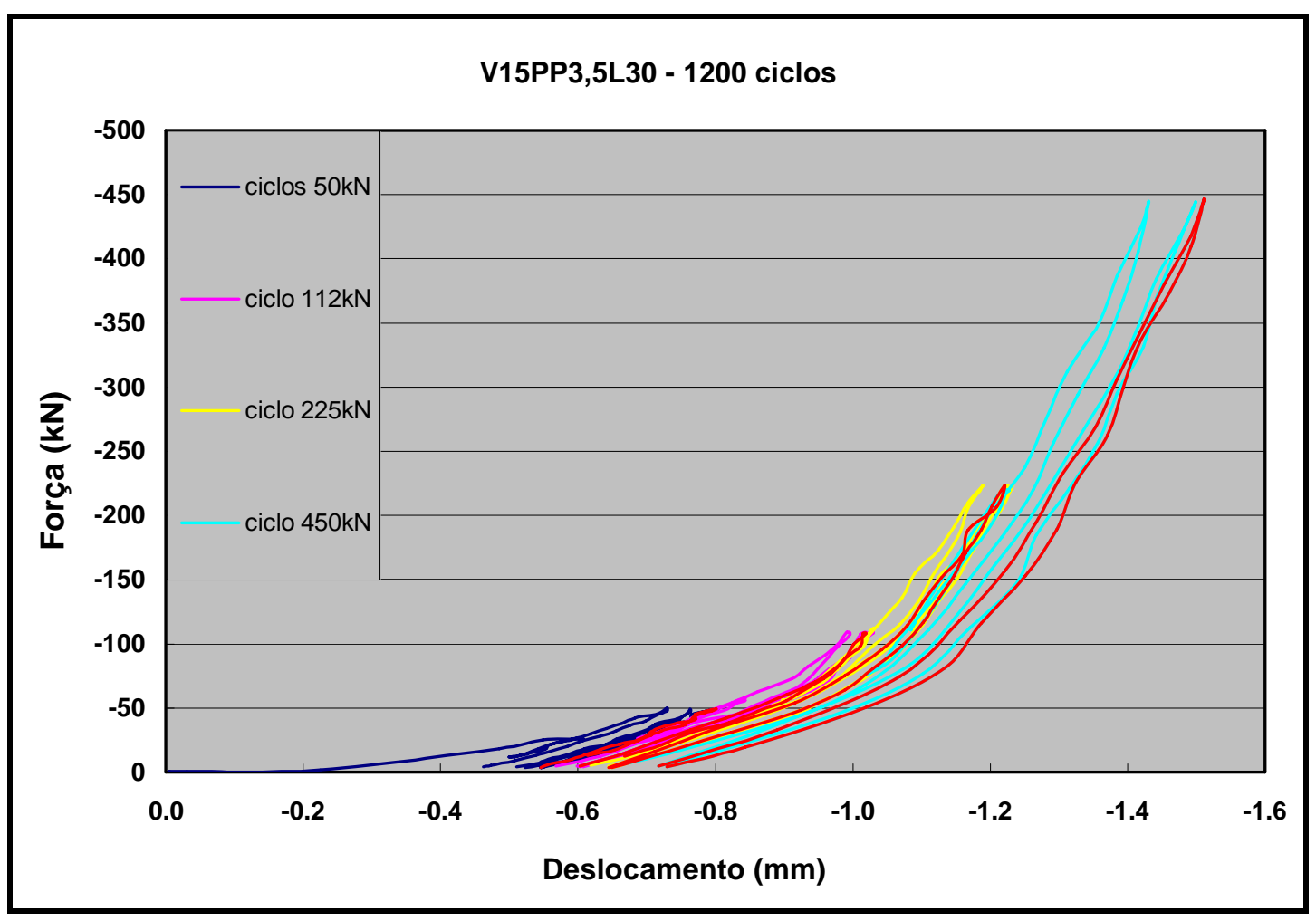

Figura 5.18:- Almofada do traço V15PP3,5L30 com 1200 ciclos de carregamento. 
Após os ensaios as almofadas mostraram-se com a mesma consistência da primeira fase do estudo, não apresentando problemas visíveis na sua estrutura, estando estas íntegras e somente com deformações discretas em sua superfície, assim como as outras almofadas.

Para o traço V15F3,5L30 ocorreu um problema na aquisição dos dados, por isso o ensaio teve de ser reiniciado, promovendo a acomodação inicial da superfície da almofada e puxando todos os valores do gráfico para deformações menores, como pode ser observado na Figura 5.18.

Deve-se ressaltar neste momento que os ensaios foram concentrados nas almofadas do traço com 10\% de vermiculita e nos traços imediatamente próximos ao mesmo, com 5 e 15\% de vermiculita, respectivamente. Adotaram-se somente estes traços de posse dos resultados das rigidezes por meio das almofadas do ensaio de carregamento monotônico.

Foram colocados em um mesmo gráfico os ciclos inicial, intermediário e final para duas almofadas do material, para se poder ter noção do comportamento da almofada com a evolução dos carregamentos, sendo uma delas submetida ao regime de 50 ciclos e a outra submetida a 300 ciclos para cada tensão de contato (Figura 5.19). 


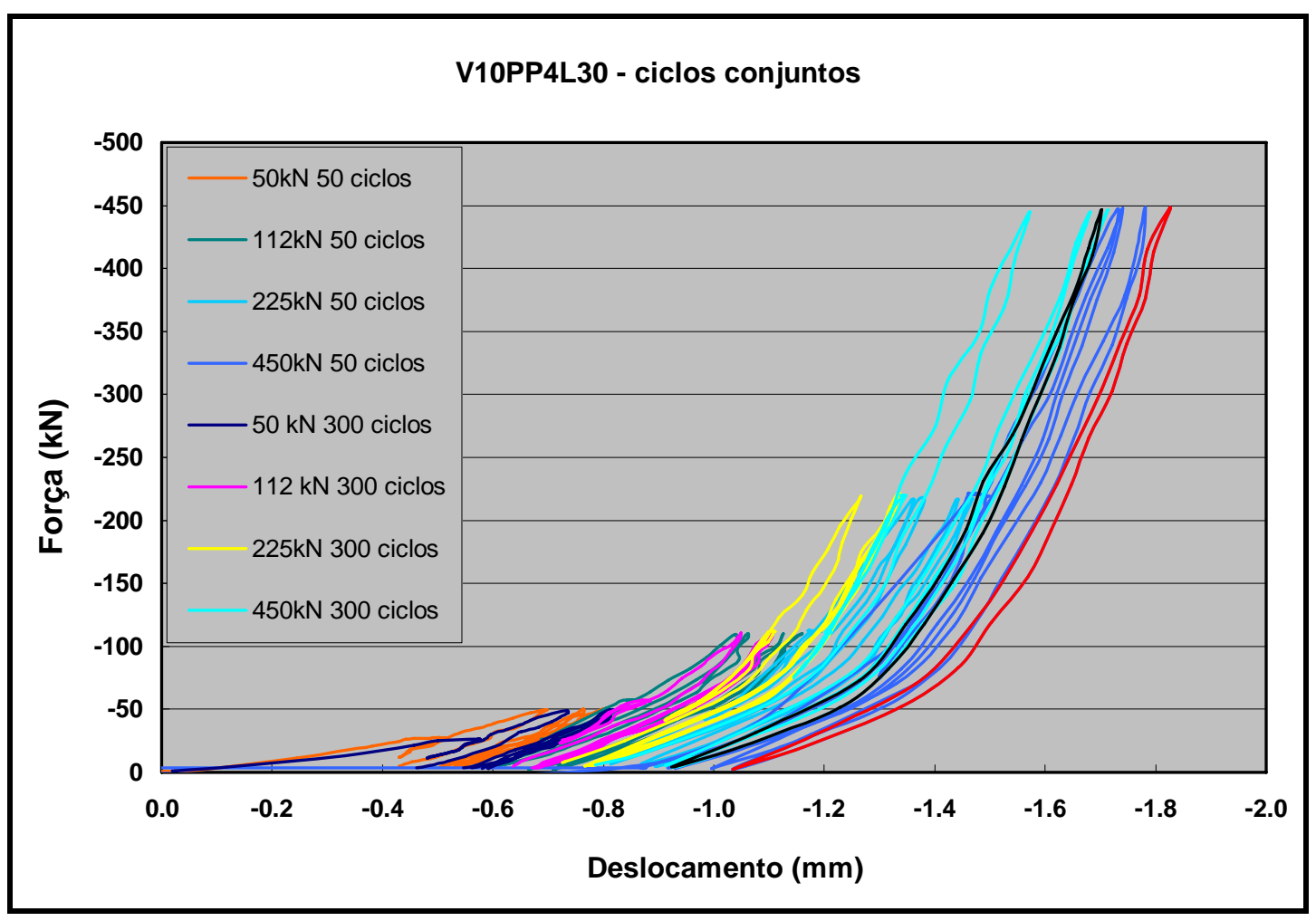

Figura 5.19: Comparação entre 50 e 200 ciclos de carga para o traço V10PP4L30.

A conclusão que se pode tirar pela análise do gráfico foi que a almofada do compósito submetida aos 1200 ciclos de carregamento, sofreu uma acomodação maior e por isso se apresentou com deformações menores durante a evolução do carregamento. É importante notar que no início do carregamento as duas almofadas possuem deformações muito próximas, sendo que a evolução do carregamento provoca uma maior acomodação para a almofada submetida a um número maior de ciclos de carregamento.

Na Tabela 5.7 são mostrados valores das deformações, para um mesmo nível de carregamento, com almofadas submetidas a carregamento monotônico, carregamento cíclico com 50 e 300 ciclos, para o traço V10PP4L30. Na Tabela 5.8 são apresentados os valores da rigidez para o último ciclo de carga de cada tipo de ensaio em comparação com a rigidez do ensaio de carregamento monotônico. 
Tabela 5.7: Comparação de valores de afundamentos para diferentes carregamentos.

\begin{tabular}{|c|c|c|c|c|}
\cline { 2 - 5 } \multicolumn{1}{c|}{} & \multicolumn{4}{|c|}{ Afundamento (mm) } \\
\hline Tipo de Carregamento & $50 \mathrm{kN}$ & $112 \mathrm{kN}$ & $225 \mathrm{kN}$ & $450 \mathrm{kN}$ \\
\hline Monotônico & 0.59 & 0.80 & 1.16 & 1.54 \\
\hline 50 Ciclos & 0.80 & 1.16 & 1.47 & 1.83 \\
\hline 300 Ciclos & 0.82 & 1.10 & 1.34 & 1.71 \\
\hline
\end{tabular}

Tabela 5.8: Comparação de valores de rigidezes para diferentes carregamentos.

\begin{tabular}{|c|c|c|c|}
\cline { 2 - 4 } \multicolumn{1}{c|}{} & \multicolumn{3}{c|}{ Rigidez $(\mathrm{MPa})$} \\
\hline Traços & 200 ciclos & 1200 ciclos & Monotônico \\
\hline V5PP4,5L30 & 420 & 370 & 388 \\
\hline V10PP4L30 & 363 & 374 & 351 \\
\hline V15PP3,5L30 & 373 & 380 & 335 \\
\hline
\end{tabular}

Pela Tabela 5.7 fica claro que o afundamento sofre uma acomodação maior para os carregamentos submetidos a um maior número de ciclos, sofrendo uma diminuição nos seus valores. Comparando-se os valores dos afundamentos sofridos com carregamento monotônico em relação ao cíclico, observa-se uma diferença nestes afundamentos, o que mostra que a rigidez dos carregamentos cíclicos é sofre uma alteração. Sendo que, essa variação no seu valor deve-se as deformações residuais que qualquer material com comportamento não elástico apresenta quando submetido a esse tipo de ensaio.

Analisando a Tabela 5.8 vemos que a rigidez não sofre grandes variações mesmo após a aplicação de um grande número de repetições de carga, mostrando assim, que o material possui capacidade resiliente.

A acomodação da rigidez após um determinado número de ciclos de carga mostra que a almofada está respondendo de maneira adequada ao seu propósito, pois, para a utilização a que se destina o material, essa capacidade resiliente é imprescindível. Acredita-se que essa propriedade fica conferida ao material devido à grande quantidade de fibra incorporada, que acaba atuando como elemento de costura das fissuras impedindo o seu aparecimento ou sua propagação, mantendo o material íntegro.

Com relação a esse aspecto, uma característica a ser ressaltada é que, apesar de a fibra utilizada nesta pesquisa ser de polipropileno, com baixo módulo de deformação, esta possui módulo de deformação maior que a rigidez das almofadas, comprovando que estas, atuam no sentido de combater o início da fissuração. Não atuando somente no 
estado pós-fissurado da argamassa, como se encontra na literatura em estudos sobre as fibras com baixo módulo de deformação.

\subsection{Ensaios de força concentrada}

Dando seqüência aos testes, foram realizados os ensaios de carga localizada, que como explicado no cap. 4, consistiram na aplicação de cargas pontuais em tiras de almofadas do compósito visando obter uma medida da capacidade de afundamento destas e através dos resultados conseguir uma medida da melhor quantidade de vermiculita a ser incorporada ao compósito.

Para este tipo de ensaio, foram realizados testes em todos os traços desenvolvidos do compósito durante a pesquisa e também foram moldadas placas para um traço sem a presença de vermiculita visando-se comprovar que a introdução desta na argamassa realmente proporciona uma maior deformabilidade do material. Na Tabela 5.9 são apresentados esses traços, lembrando que para cada traço foram ensaiadas 10 tiras de almofada, dos quais foi realizada uma análise visual das amostras com o mesmo tipo de comportamento e assim, o comportamento médio para o material foi assumido como sendo o valor destas amostras.

Tabela 5.9: Traços estudados no ensaio de carga localizada.

\begin{tabular}{cc}
\hline Traço & Descrição \\
\hline V0PP5L30 & 0\% de vermiculita e 5\% de fibra \\
V5PP4,5L30 & $5 \%$ de vermiculita e 4,5\% de fibra \\
V10PP4L30 & $10 \%$ de vermiculita e $4 \%$ de fibra \\
V15PP3,5L30 & $15 \%$ de vermiculita e 3,5\% de fibra \\
V20PP3L30 & $20 \%$ de vermiculita e $3 \%$ de fibra \\
V25PP2,5L30 & $25 \%$ de vermiculita e $2,5 \%$ de fibra \\
\hline
\end{tabular}

Neste ensaio, tentou-se traduzir uma tendência para as curvas de afundamento das amostras do material, por meio de carregamento sempre com controle dos deslocamentos da máquina de ensaio. Como se tratam de várias tiras de almofadas, a 
variabilidade dos resultados é relativamente grande, necessitando de uma análise criteriosa no momento de verificação da tendência dos afundamentos sofridos por cada traço. Nas figuras 5.20 e 5.21 são apresentados os conjuntos de curvas para o traço V10PP4L30.

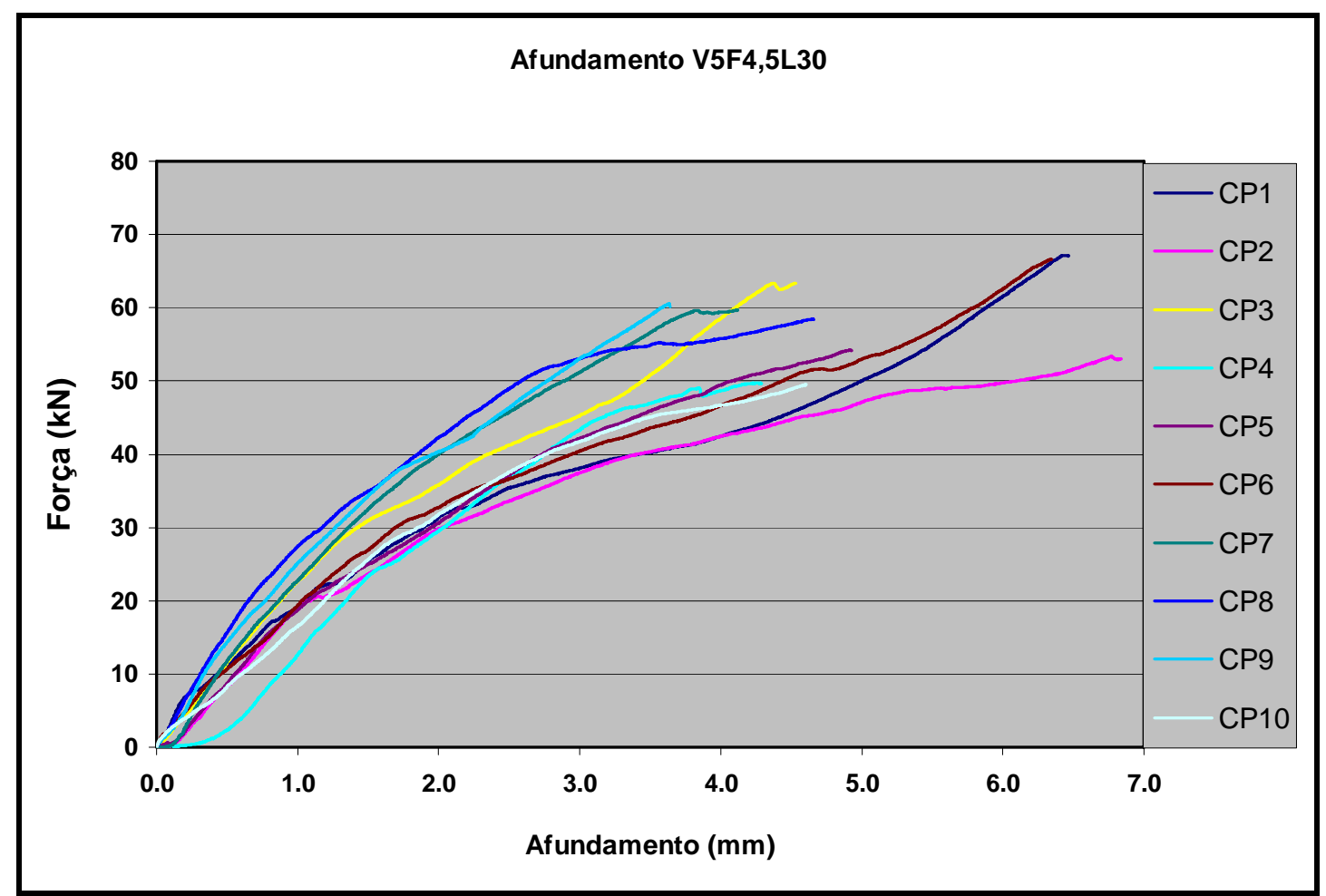

Figura 5.20: Curvas das 10 amostras do ensaio de carga localizada para o traço V5PP4,5L30. 


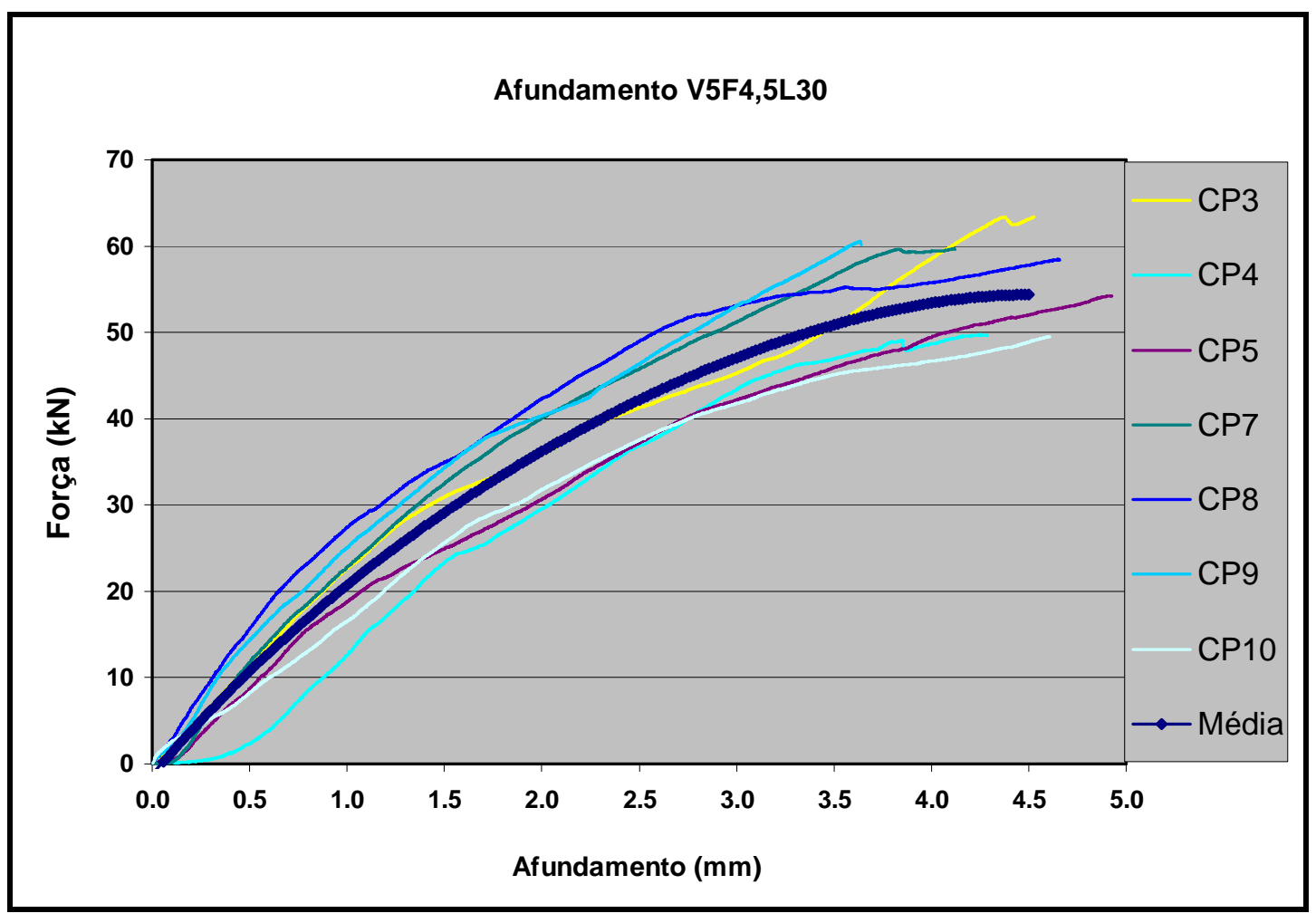

Figura 5.21: Curva média das amostras do ensaio de carga localizada para o traço V5PP4,5L30.

Como se pode se observar pelas figuras, o tratamento foi feito pela tendência de acomodação dos pontos próximos a um valor de afundamento. As curvas com comportamento muito diferente do apresentado pela maioria das amostras foram eliminadas da análise. A partir da retirada de algumas curvas, que se mostraram muito dispersas, traçou-se uma curva média para as amostras de cada traço. A mesma análise feita para uma amostra foi realizada para as demais, portanto, não serão apresentados os valores de cada traço em separado, sendo apresentadas as curvas médias de cada traço. Com esse valor médio das curvas de força aplicada por afundamento sofrido, foram plotados os valores de todos os traços em um mesmo gráfico, de maneira a facilitar a visualização do comportamento de todos esses traços estudados. A Figura 5.22 traz os gráficos da média dos afundamentos para todas as amostras dos traços estudados. 


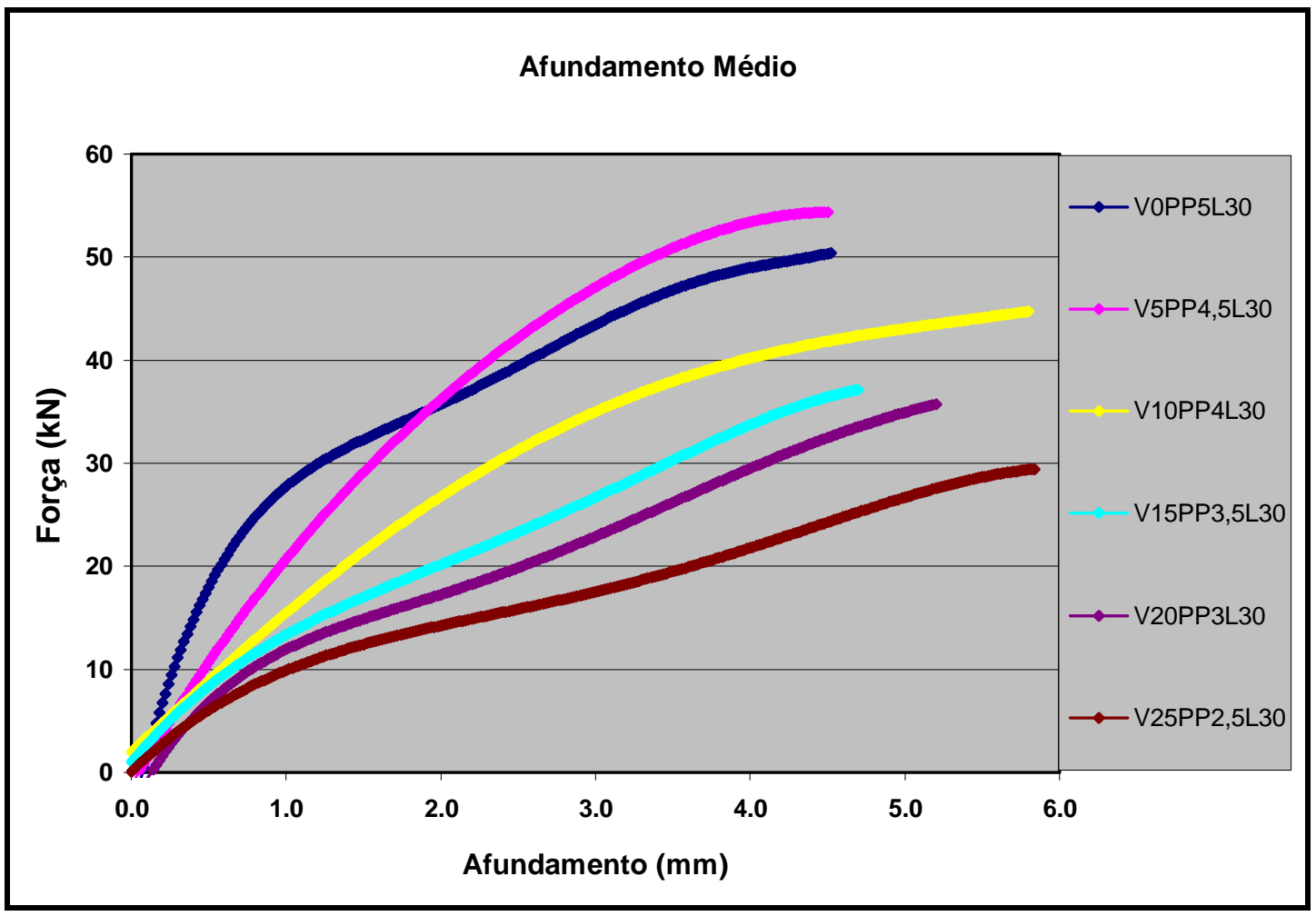

Figura 5.22: Curvas médias das amostras dos ensaios de carga localizada.

No início do carregamento, pode-se observar um comportamento bem definido do material, em que, quanto menor a quantidade de vermiculita empregada na amostra existe um aumento da rigidez das almofadas, evidenciando o aumento da deformabilidade do compósito com a adição da vermiculita. Com a evolução do carregamento esse comportamento começa a desaparecer, porque ocorre o esmagamento da almofada e as fibras começam a atuar no sentido de manter a coesão da tira da almofada, como pode ser observado na Figura 5.23.

Quando o carregamento começa a esmagar a tira da almofada e começa a fissuração na região localizada abaixo dos pontos de aplicação das forças, a inclinação da curva sofre uma pequena alteração. Sendo esta menos pronunciada nos traços com o aumento da quantidade de vermiculita ou mais pronunciada como no caso do traço sem vermiculita, onde existe uma mudança brusca na inclinação da curva, como pode ser observado na Figura 5.22.

Na região central das tiras da almofada, entre os pontos de aplicação de carga, ocorre um confinamento da peça, gerando tensões de tração nessa região e provocando a 
ruptura dessa região da tira por tensão de tração, este fenômeno pode ser observado na Figura 5.24.

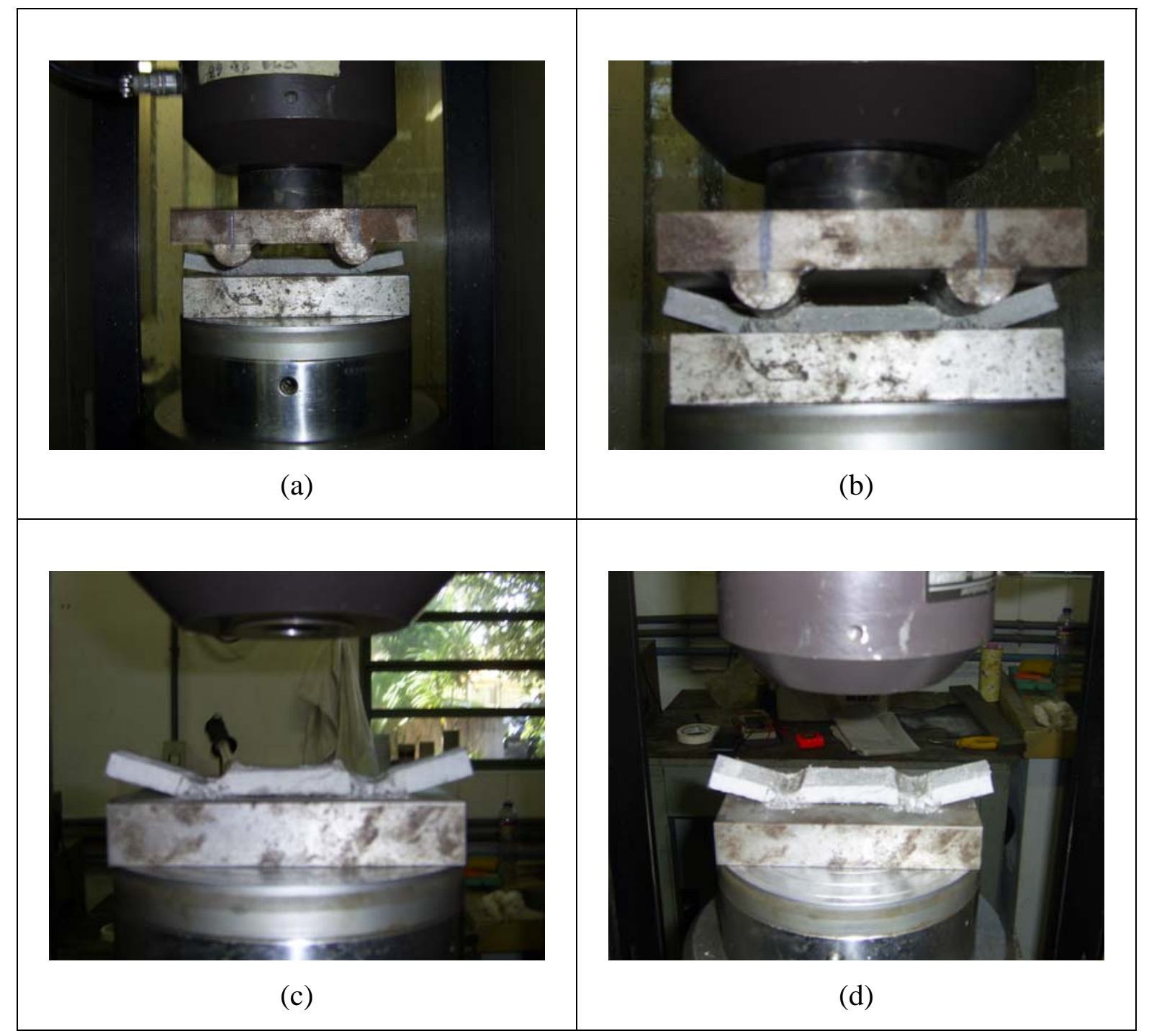

Figura 5.23: Evolução do carregamento nas tiras do compósito. 


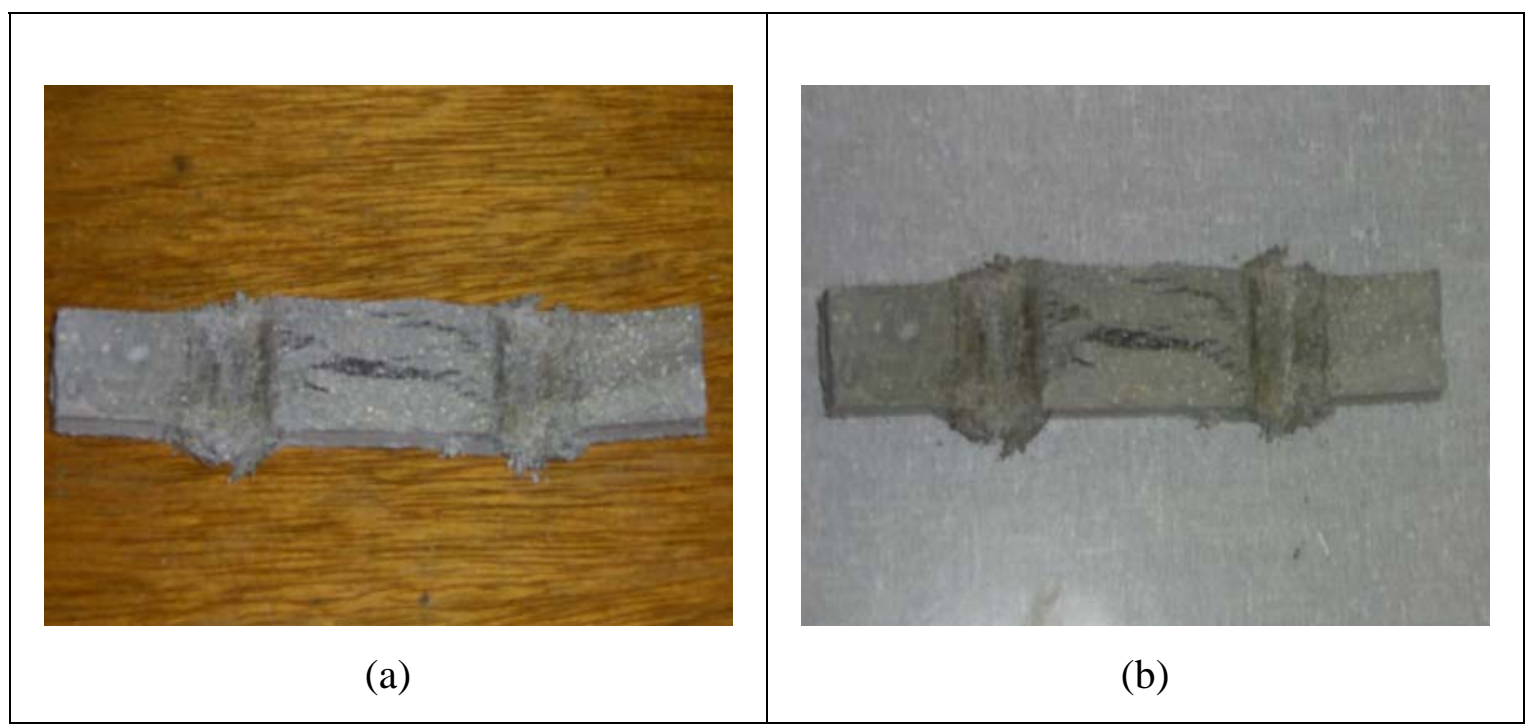

Figura 5.24: Ruptura das tiras da almofada por tração.

Na tentativa de gerar valores que sejam palpáveis no que diz respeito à medida da melhor quantidade de vermiculita a ser incorporada ao compósito, teve-se a idéia de utilizar o produto entre a força aplicada e o afundamento máximo sofridos pela tira de almofada, ou seja, o trabalho plástico da amostra. Esse é um valor que tenta quantificar a melhor quantidade de vermiculita a ser incorporada no compósito, comparando-se todos os traços estudados. Portanto, na Figura 5.25, são apresentados os valores desse fator.

A Figura 5.25 nos mostra que o traço com $10 \%$ de vermiculita se mostrou com o maior valor para o produto entre a força e o afundamento, evidenciando sua maior habilidade em suportar maiores níveis de carregamento localizado sem sofrer ruptura ou danos irreversíveis às almofadas provenientes da utilização deste traço. O que se pode verificar analisando-se as figuras 5.22 e 5.25 é que as almofadas com pequena quantidade de vermiculita e muita fibra possuem uma maior resistência inicial, rompendo-se com valores de afundamentos menores. As tiras com porcentagens altas de vermiculita incorporada são mais deformáveis, porém admitem cargas bem inferiores. 


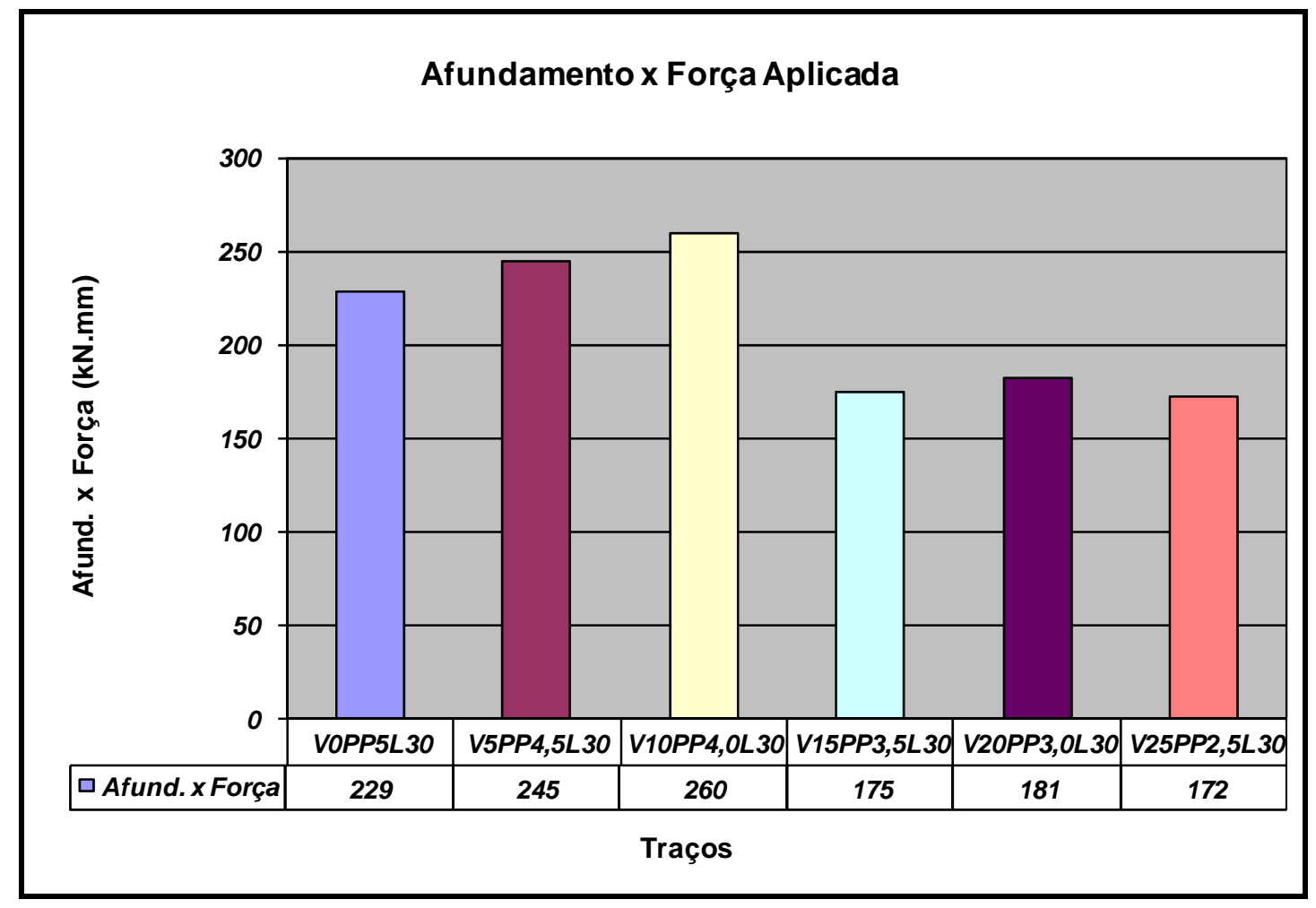

Figura 5.25: Gráfico do produto afundamento $\mathrm{x}$ força.

Cabe aqui ressaltar que os afundamentos verificados nas tiras não correspondem aos seus valores reais, somam-se a esses as folgas da máquina e dos equipamentos necessários ao ensaio, por isso, os valores obtidos podem ser adotados como valores de verificação, que tendem a mostrar um comportamento melhor para o traço V10PP4L30. Não podendo este sozinho ser fator preponderante na escolha do melhor traço para a confecção das almofadas, mas sim um parâmetro que em conjunto com todos os outros estudos indique a melhor opção.

\subsection{Ensaios de ligação de blocos}

Após a realização dos ensaios anteriores e de posse dos resultados que indicavam o traço V10F4L30 como sendo o mais indicado a ser utilizado na confecção das almofadas para elemento de apoio, partiu-se para a efetiva verificação da capacidade de atuação do compósito. Para tanto, foram realizados os ensaios de ligação de blocos, que simulam uma ligação do tipo pilar-pilar para elementos pré-moldados, podendo-se 
assim, visualizar a capacidade de transmissão das tensões e a acomodação das imperfeições inerentes a região da interface entre elementos.

Como explicado no capítulo 4, os ensaios foram divididos em duas etapas, aqui denominadas de séries de ensaios somente para facilitar a análise e visualização dos resultados. Inicialmente os resultados serão apresentados separadamente para cada série e no final será desenvolvida uma discussão de todos os resultados em conjunto.

\section{Série:}

A primeira série de ensaios consistiu na utilização de blocos prismáticos de $15 \mathrm{~cm}$ de base com altura de $30 \mathrm{~cm}$ e, cubos de $15 \mathrm{~cm}$ de lado que foram superpostos para o ensaio. Na Tabela 5.10 são apresentados os resultados desse ensaio.

Tabela 5.10: Resistências dos blocos da $1^{\mathrm{a}}$ série de ensaios.

\begin{tabular}{|c|c|c|c|}
\hline \multicolumn{2}{|c|}{ Prismas } & Cilindros (*) \\
\hline Dimensões (cm) & Resistência (MPa) & Descrição & Resistência (MPa) \\
\hline $15 \times 15 \times 30$ & 38,7 & Sem emenda & 58,0 \\
\hline $15 \times 15 \times 15$ & 33,4 & Liso com almofada & 56,5 \\
\hline $15 \times 15 \times 15$ & 32,7 & Liso sem almofada & 52,0 \\
\hline
\end{tabular}

(*) Diâmetro de 100mm e altura de 200mm.

Pela Tabela 5.10, pode-se ver que a presença da almofada nos blocos com emenda já proporcionaram uma pequena melhora na acomodação das tensões e imperfeições da região das ligações, promovendo uma correta transmissão dos esforços, melhorando um pouco a resistência dos blocos. É importante notar que a resistência do concreto do ensaio dos blocos lisos e com almofada se apresentou um pouco menor do que os outros elementos da série, como mostram os valores dos corpos-de-prova cilíndricos, moldados para o controle do concreto. Portanto, a ligação dos blocos lisos com almofada se apresentou com melhor desempenho do que a ligação dos blocos lisos sem almofada.

Na Figura 5.26 os valores das resistências dos prismas são apresentados na forma de gráfico para facilitar sua visualização. 


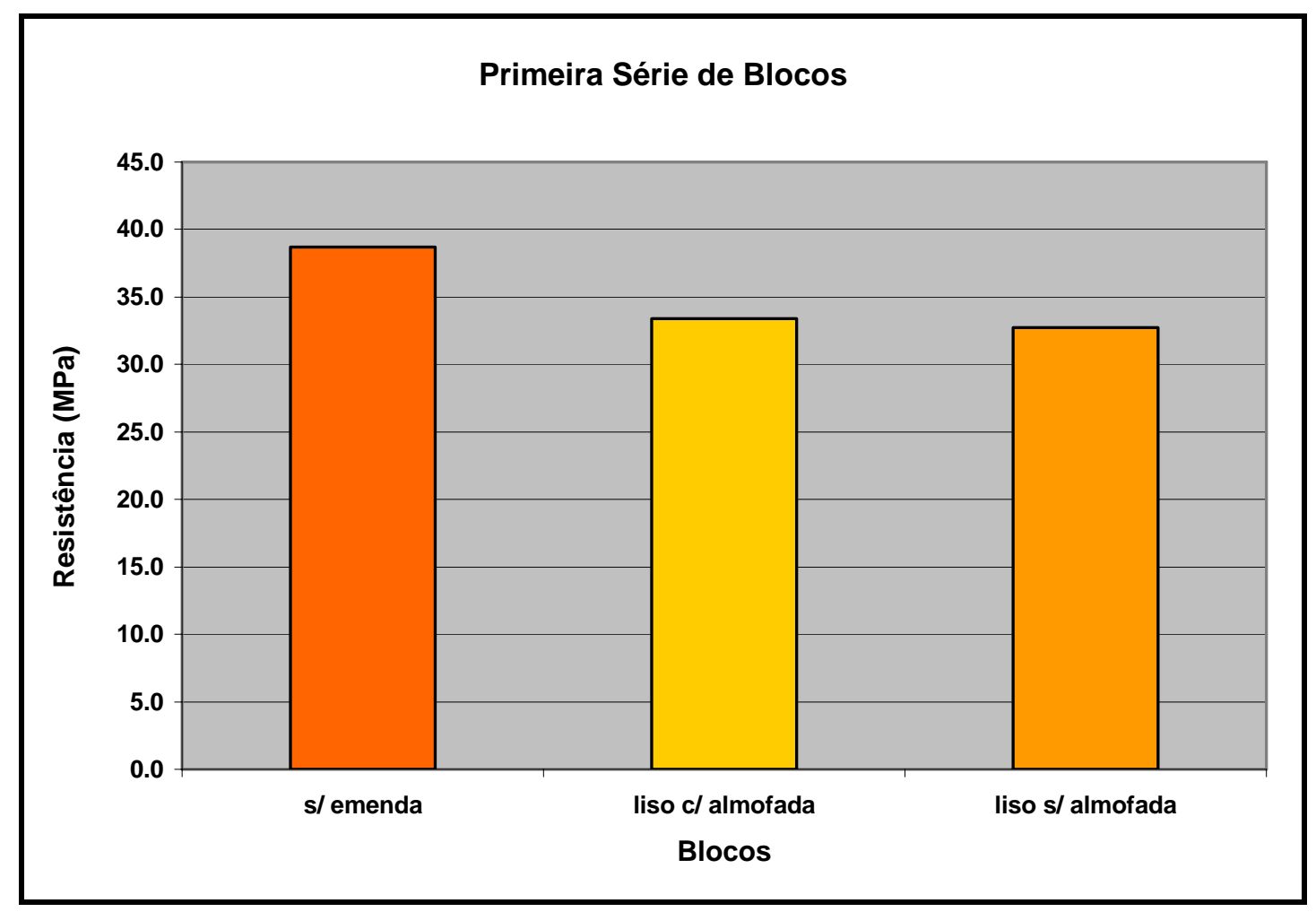

Figura 5.26: Blocos da primeira série de ensaios.

\section{$\underline{2^{a}}$ Série:}

Na segunda série de ensaios foram introduzidas rugosidades na face de contato do corpo-de-prova que ficaria sobreposto no momento do ensaio, sendo que sobre o bloco que serviria de base continha em sua extremidade almofada ou o contato era do tipo junta seca. Na Tabela 5.11 são apresentados os resultados para os ensaios com as rugosidades estudadas.

Tabela 5.11: Resistências dos blocos da $2^{\mathrm{a}}$ série de ensaios.

\begin{tabular}{|c|c|c|c|}
\hline \multicolumn{2}{|c|}{ Prismas } & Cilindros (*) \\
\hline Dimensões (cm) & Resistência (MPa) & Descrição & Resistência (MPa) \\
\hline \multirow{2}{*}{$15 \times 15 \times 15$} & 32,7 & Rugosidade $0,75 \mathrm{~mm}$ com almofada & 55,5 \\
\cline { 2 - 4 } & 20,3 & Rugosidade $0,75 \mathrm{~mm}$ sem almofada & 58,0 \\
\hline \multirow{2}{*}{$15 \times 15 \times 15$} & 25,9 & Rugosidade 1,00mm com almofada & 38,0 \\
\cline { 2 - 4 } & 18,1 & Rugosidade 1,00mm sem almofada & 53,0 \\
\hline \multirow{2}{*}{$15 \times 15 \times 15$} & 23,0 & Rugosidade 1,50mm com almofada & 61,0 \\
\cline { 2 - 4 } & 20,6 & Rugosidade $1,50 \mathrm{~mm}$ sem almofada & 56,5 \\
\hline
\end{tabular}

(*) Diâmetro de $100 \mathrm{~mm}$ e altura de $200 \mathrm{~mm}$. 
Pelos dados da Tabela 5.11 pode-se visualizar que a presença da almofada apresentou uma melhora significativa nas resistências dos blocos. Com o aumento das rugosidades, os valores das resistências sofreram significativas reduções, mas sempre com valores maiores na presença da almofada, evidenciando que o comportamento da ligação tem seu desempenho melhorado nessa situação. A Figura 5.27 mostra os valores na forma de gráfico.

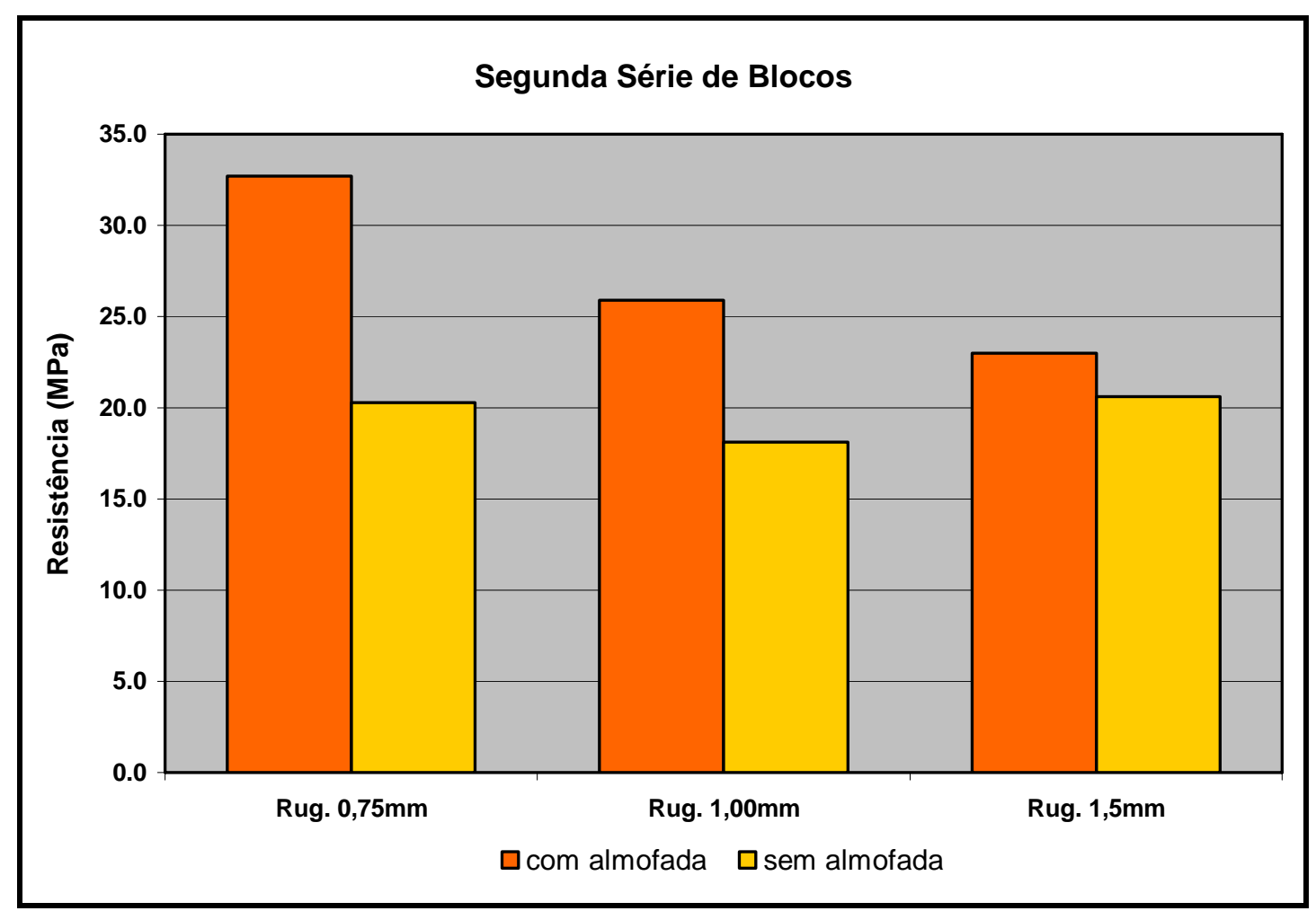

Figura 5.27: Blocos da segunda série de ensaios.

Para os blocos com rugosidade de $1,0 \mathrm{~mm}$, pode-se notar que existe uma grande diferença na resistência do concreto para os blocos com e sem almofadas, que pode ser visualizada nos corpos-de-prova cilíndricos. Este fato deve ter ocorrido pela mudança no lote do cimento utilizado entre as concretagens dos elementos da série com e sem as almofadas, que foram realizadas em datas diferentes e, porque as resistências para todos os outros traços que foram ensaiados se apresentaram com um padrão mais próximo de resistência. O fator positivo que se pode analisar através disso é que mesmo com um concreto menos resistente do que para o mesmo ensaio sem a presença da almofada, os resultados dos blocos com a almofada, se apresentaram com resistência maior, 
mostrando a atuação da almofada no sentido de uma melhor distribuição das tensões na região da ligação.

Finalizando a análise desse ensaio, todos os resultados foram colocados em um mesmo gráfico, podendo-se promover as comparações entre todos os blocos ensaiados e, podendo-se também visualizar a evolução das suas respectivas resistências(Figura. 5.28).

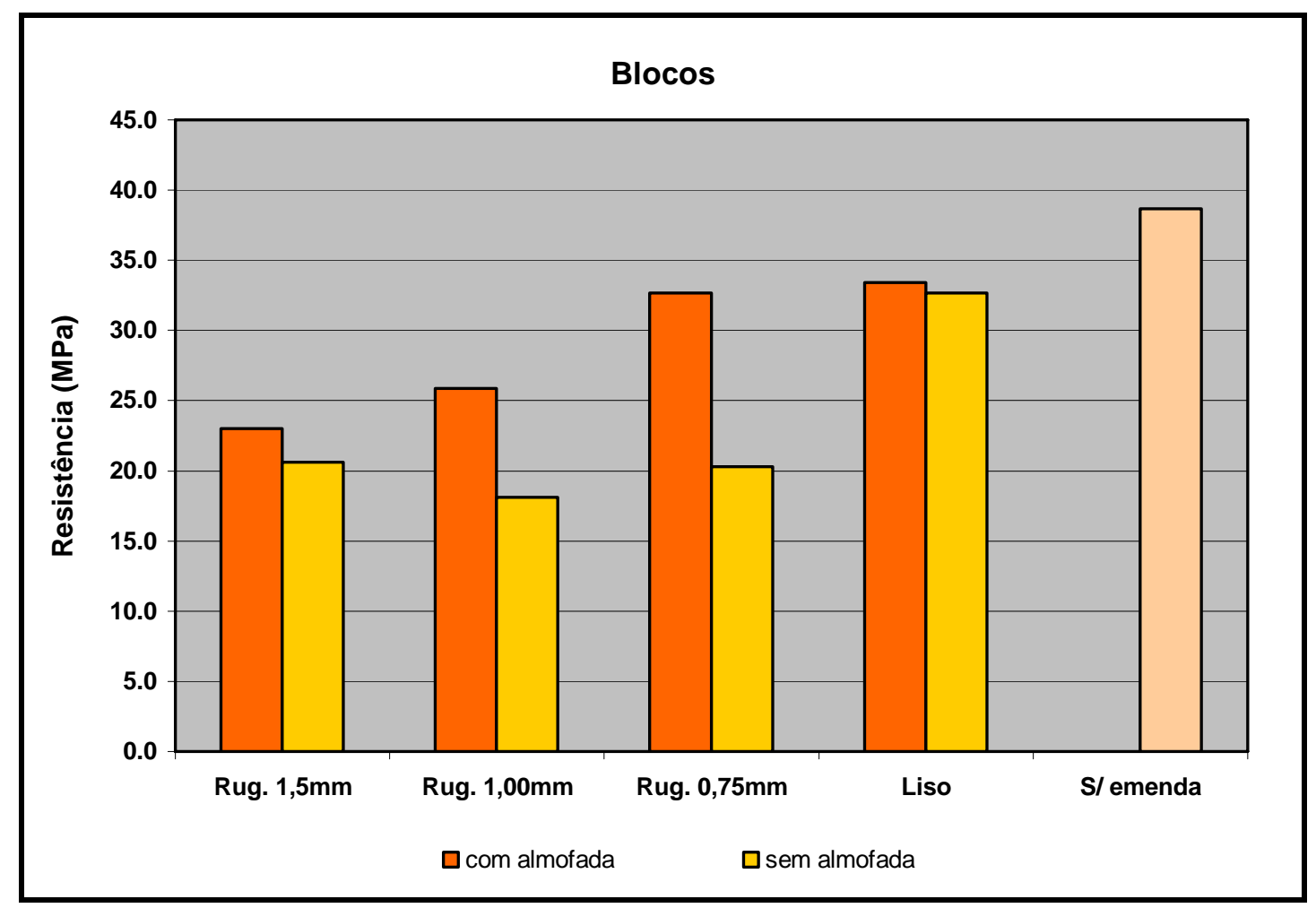

Figura 5.28: Conjunto dos ensaios de ligação de blocos.

A Figura 5.28 traduz e evidencia toda a evolução do comportamento das ligações entre blocos com e sem presença de almofadas e rugosidades variadas.

O padrão de ruptura apresentado para os blocos está apresentado nas figuras 5.29 e 5.30 . 


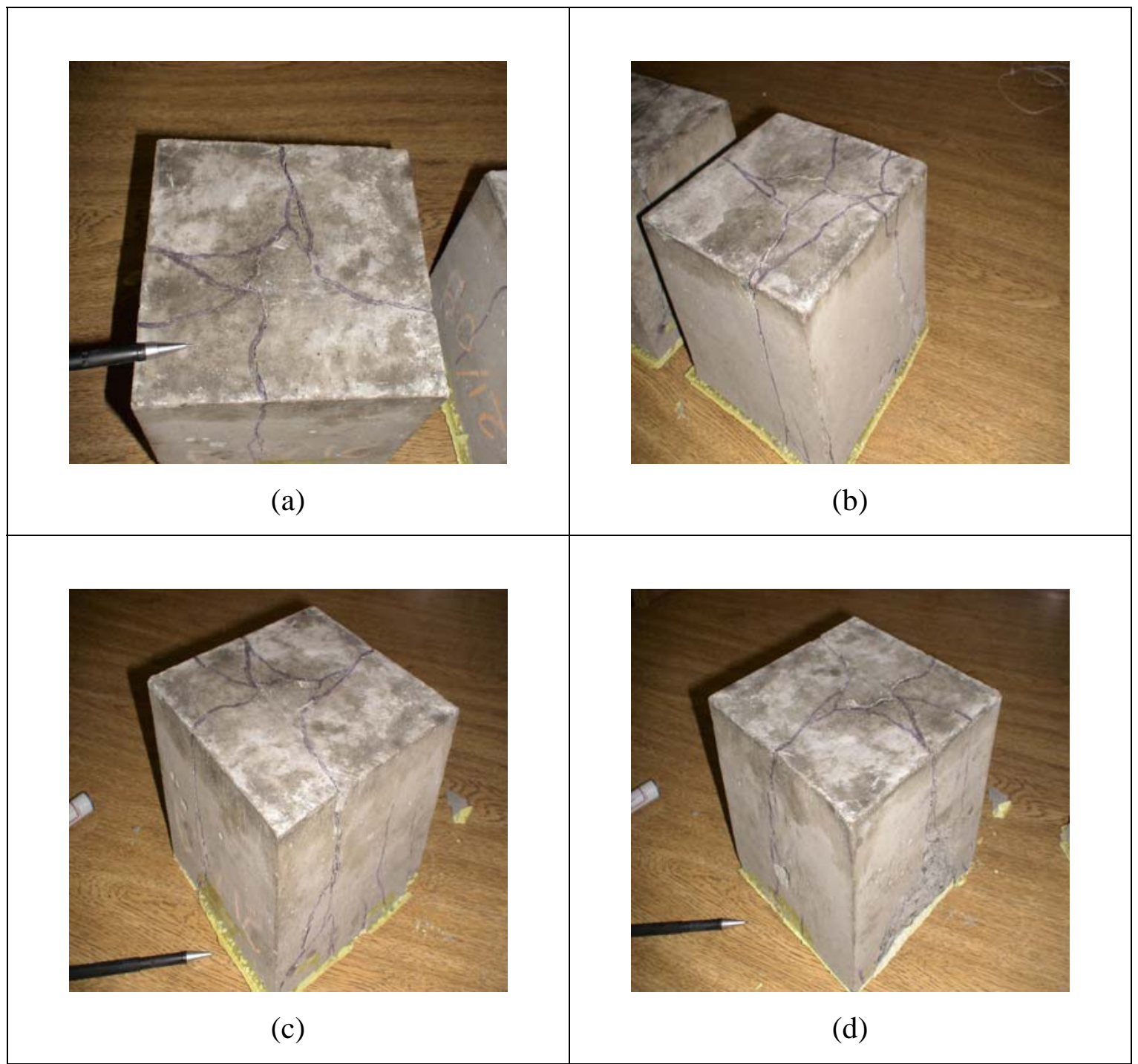

Figura 5.29: Ruptura dos blocos lisos.

Para os blocos lisos, o padrão de ruptura observado foi o de fissuras que se concentravam mais na região central dos blocos, se propagando de uma face à outra de cada bloco, mostrando-se com o mesmo comportamento para um mesmo par de blocos superpostos, na presença ou não das almofadas. Já no caso dos blocos rugosos, as fissuras se propagavam mais próximas às extremidades destes, tendendo ao arrancamento de suas arestas devido a localização das tensões provocadas pelas rugosidades, como pode ser observada na Figura 5.30. As fissuras se propagavam para os dois blocos estudados, sendo que a almofada apresentava fissuras na mesma posição das fissuras que se propagavam pelos blocos. 


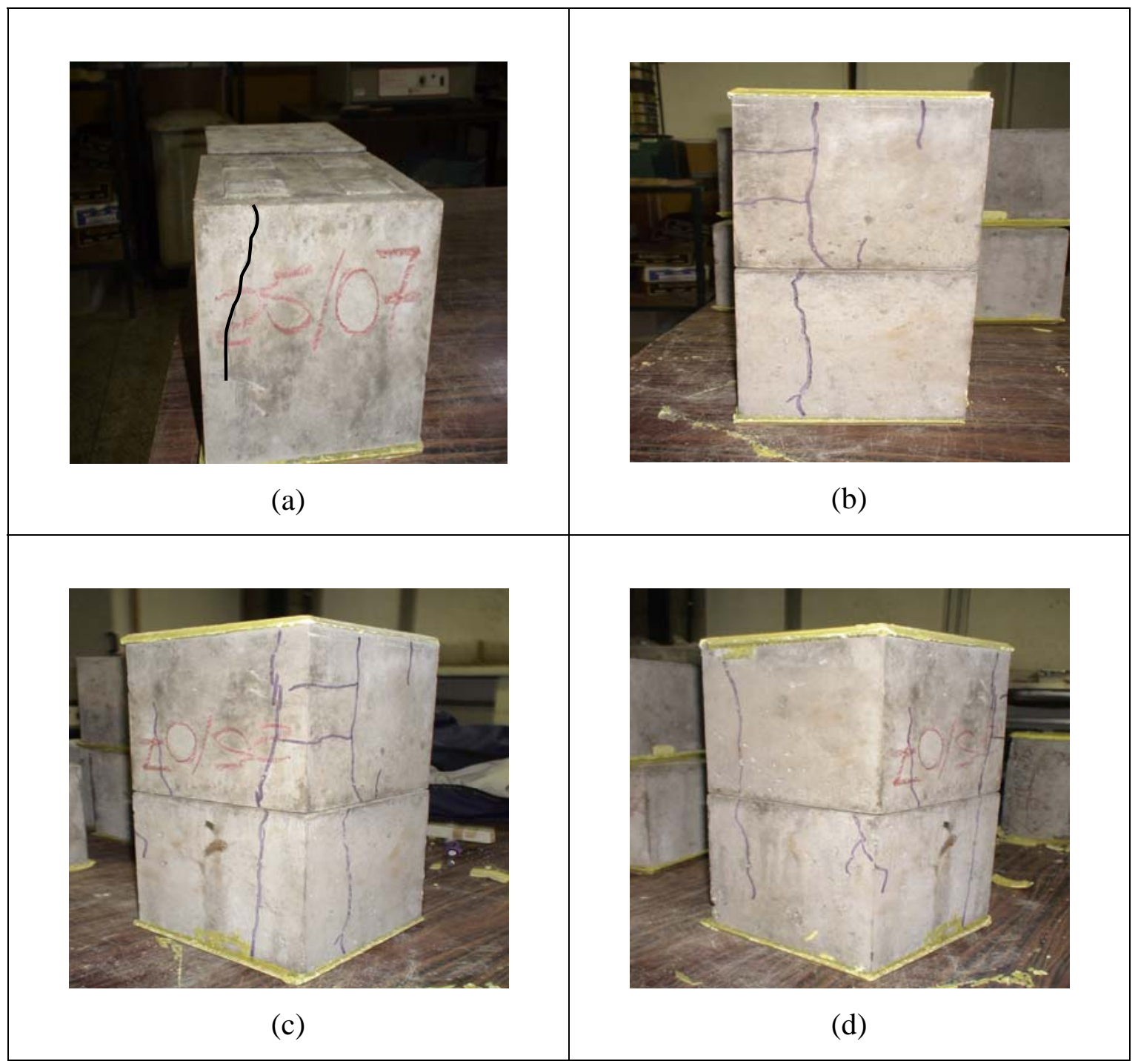

Figura 5.30: Ruptura dos blocos rugosos.

\subsection{Ensaios de rotação}

Para completar a série de verificações acerca do comportamento das almofadas, esta série de ensaios de rotação foi desenvolvida para se tentar determinar a capacidade de rotação que efetivamente se poderia aplicar sobre o material sem que esse sofresse danos irreversíveis e perdesse a capacidade de atuação como elemento de apoio.

Nesta pesquisa, como mostrado no capítulo 4, a capacidade de rotação das almofadas foi verificada aplicando-se uma carga excêntrica sobre uma chapa metálica, 
ocasionando sua rotação. Essa rotação da chapa metálica foi transmitida efetivamente às almofadas do compósito.

Para a correta verificação dos resultados, está apresentada na Figura 5.31 uma planta de posicionamento dos relógios bem como a nomenclatura do posicionamento da chapa metálica.

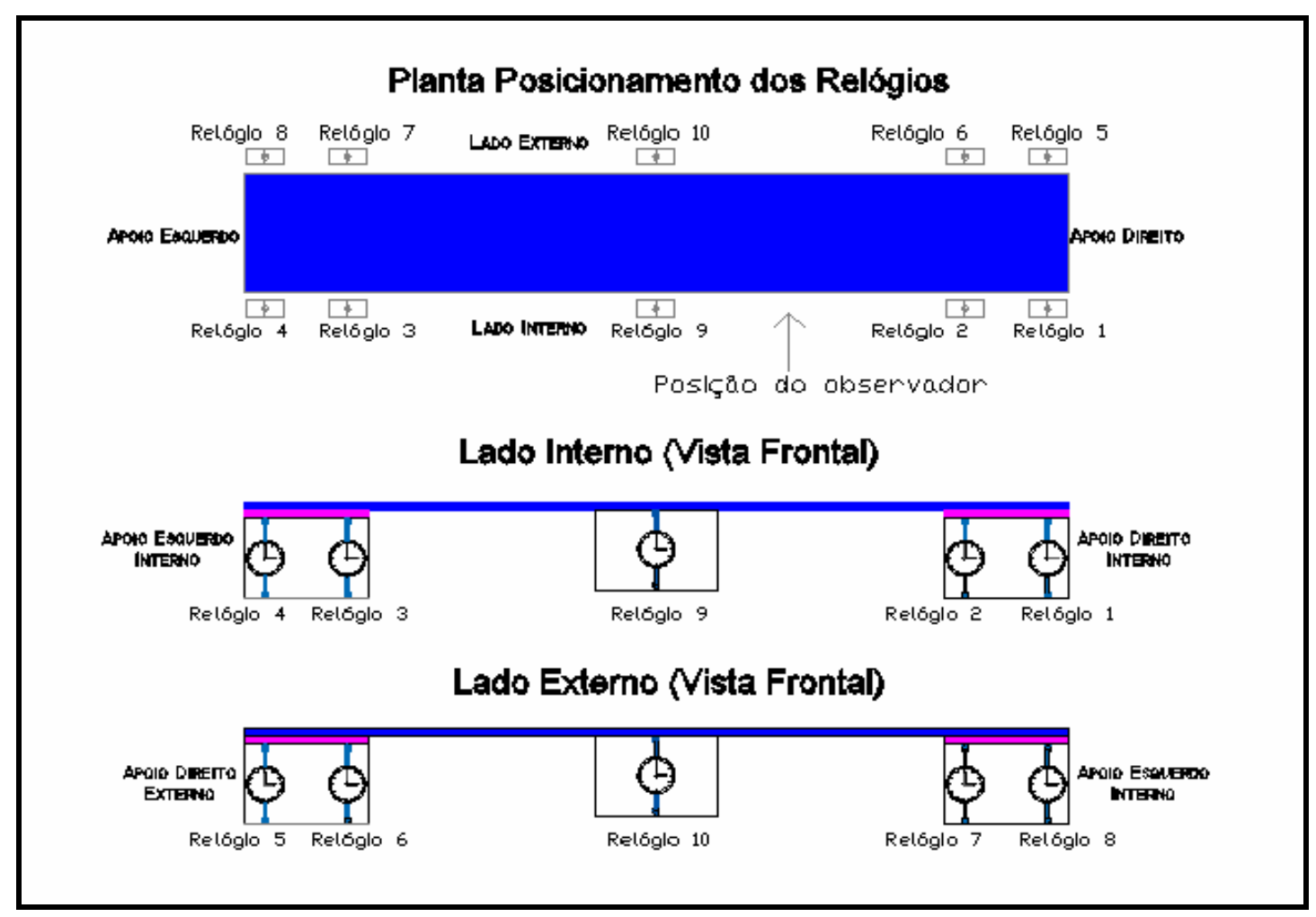

Figura 5.31: Planta de posicionamento dos relógios do ensaio de rotação.

Neste ensaio foram moldadas almofadas de três traços do material, sendo estas de duas espessuras diferentes, $10 \mathrm{~mm}$ e 20mm. Os traços estudados foram o V5PP4,5L30, V10PP4L30 e o V15PP3,5L30, com 150mm x 150mm de base. Estes traços foram escolhidos devido ao melhor desempenho apresentado nos resultados anteriores com valores de incorporação de vermiculita em torno de $10 \%$.

Os dados experimentais provenientes dos ensaios foram colocados em gráficos e serão apresentados a seguir. A apresentação dos resultados será feita por traço e espessura da almofada. Pode-se verificar que o trecho de carregamento dos gráficos apresenta valores menores de deslocamento. Ao final do carregamento e início do descarregamento das 
almofadas, estas apresentam uma acomodação lenta e com valores de deslocamentos crescentes até determinados níveis de carga. Isso se deve a lentidão da volta do pistão do macaco hidráulico no processo de descarregamento das almofadas. Após um valor de tensão, os valores de deslocamento dos relógios voltam a descer normalmente se aproximando de zero, como pode ser observado nos gráficos.

\section{V5PP4,5L30:}

\section{1) Almofada com espessura de $10 \mathrm{~mm}$ e excentricidade de $6,0 \mathrm{~cm}$ :}

$\checkmark$ Deslocamento nos Apoios: A Figura 5.32 traz os deslocamentos médios nos apoios para almofadas com espessura de $10 \mathrm{~mm}$.

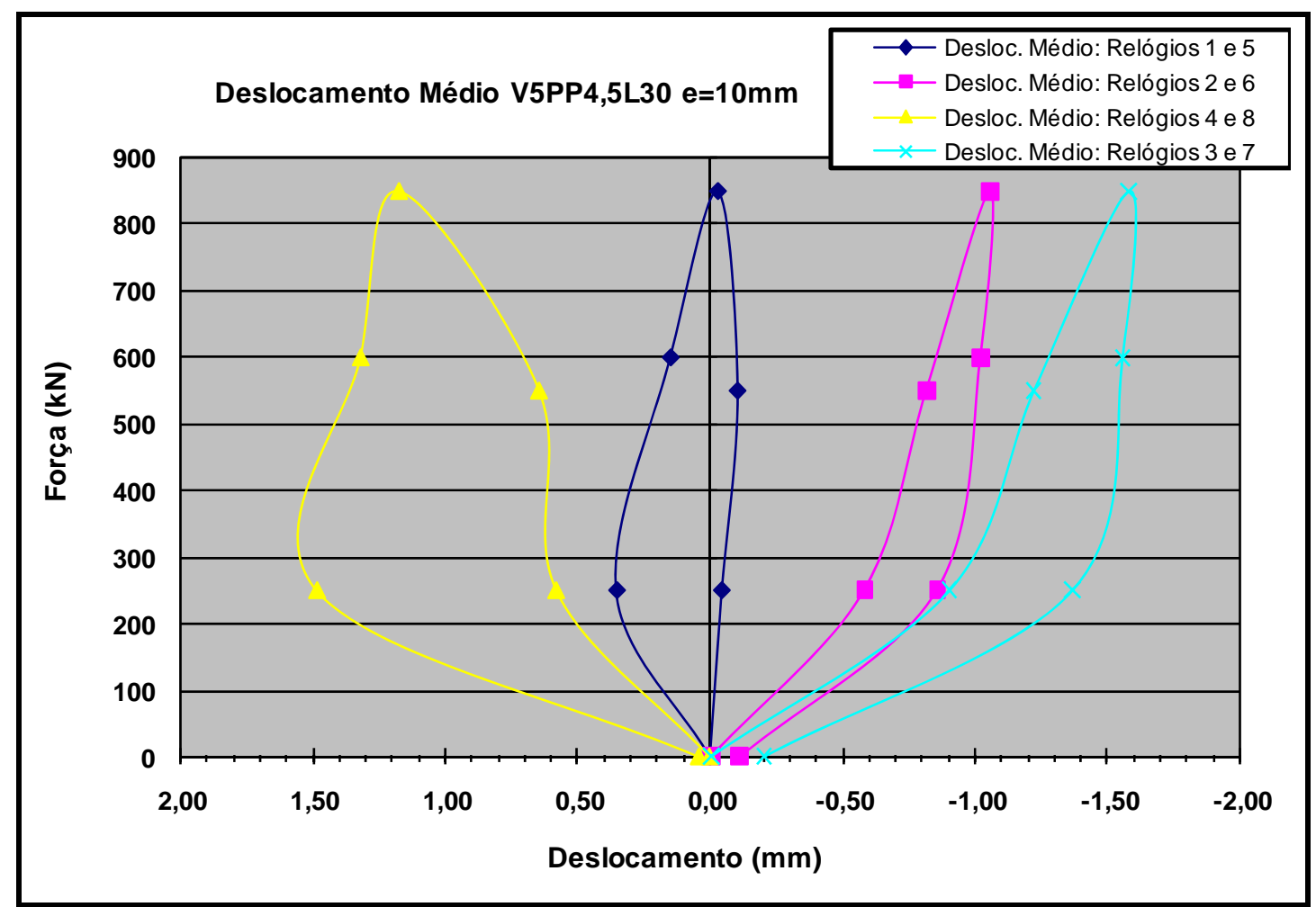

Figura 5.32: Deslocamento médio para o traço V5PP4,5L30 e=10mm.

$\checkmark$ Rotações nos Apoios: Nas figuras 5.33 e 5.34 são apresentados os resultados das rotações nos apoios para as almofadas com espessura de $10 \mathrm{~mm}$. 


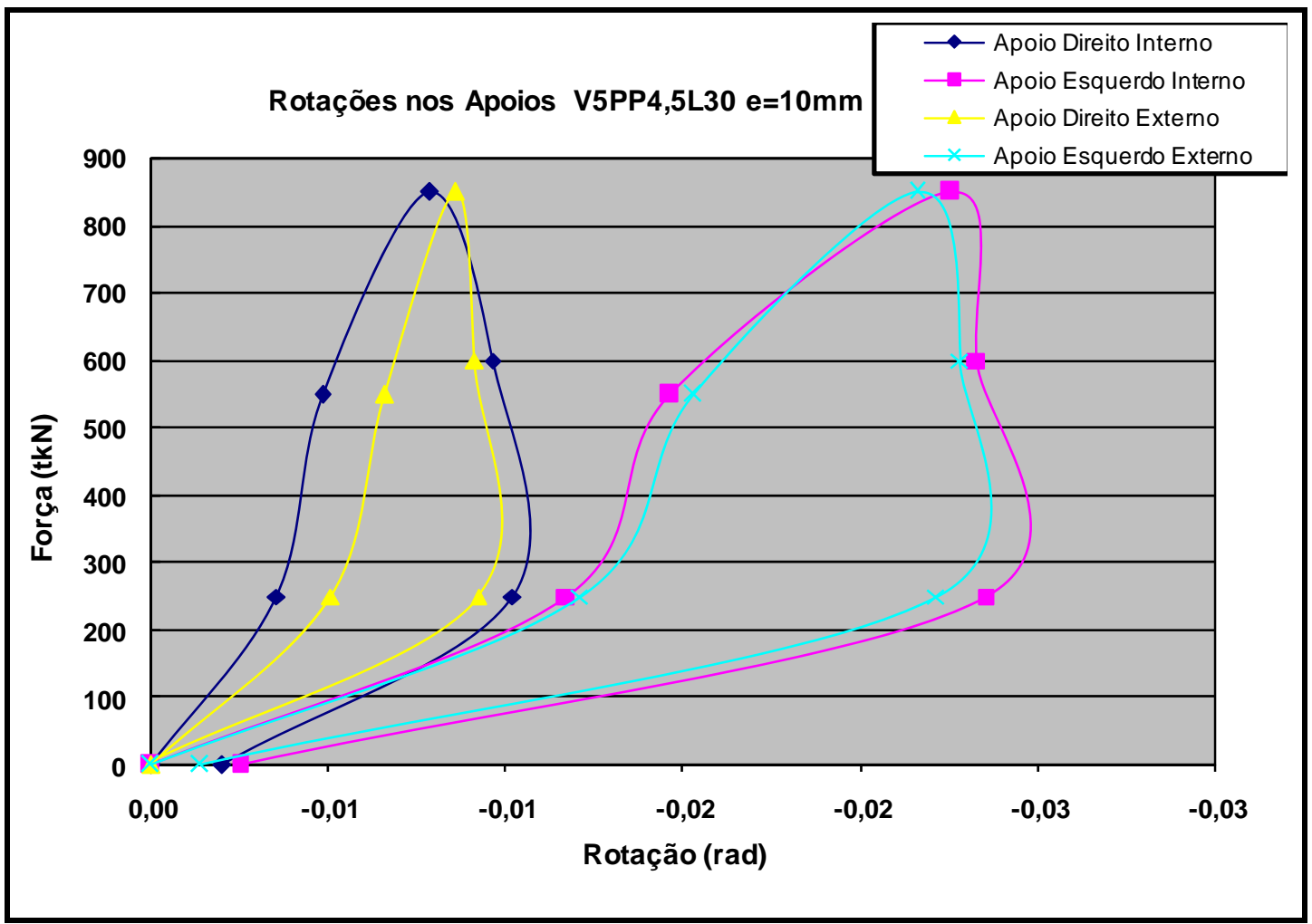

Figura 5.33: Rotações nos apoios para o traço V5PP4,5L30 e=10mm.

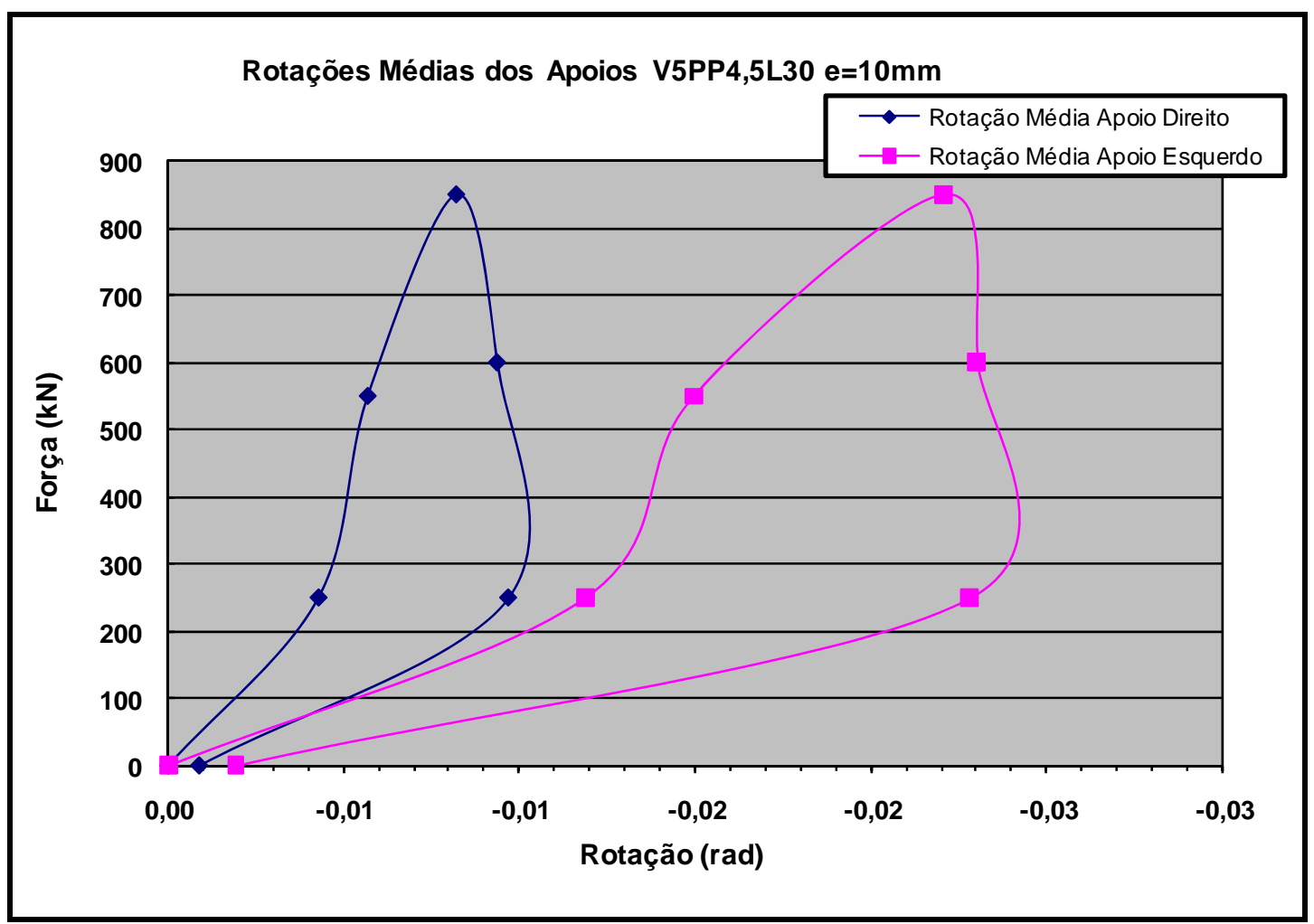

Figura 5.34: Rotações médias dos apoios para o traço V5PP4,5L30 e=10mm. 
2) Almofada com espessura de $20 \mathrm{~mm}$ e excentricidade de $5,5 \mathrm{~cm}$ :

$\checkmark$ Deslocamento nos Apoios: A Figura 5.35 traz os deslocamentos médios nos apoios para almofadas com espessura de $20 \mathrm{~mm}$.

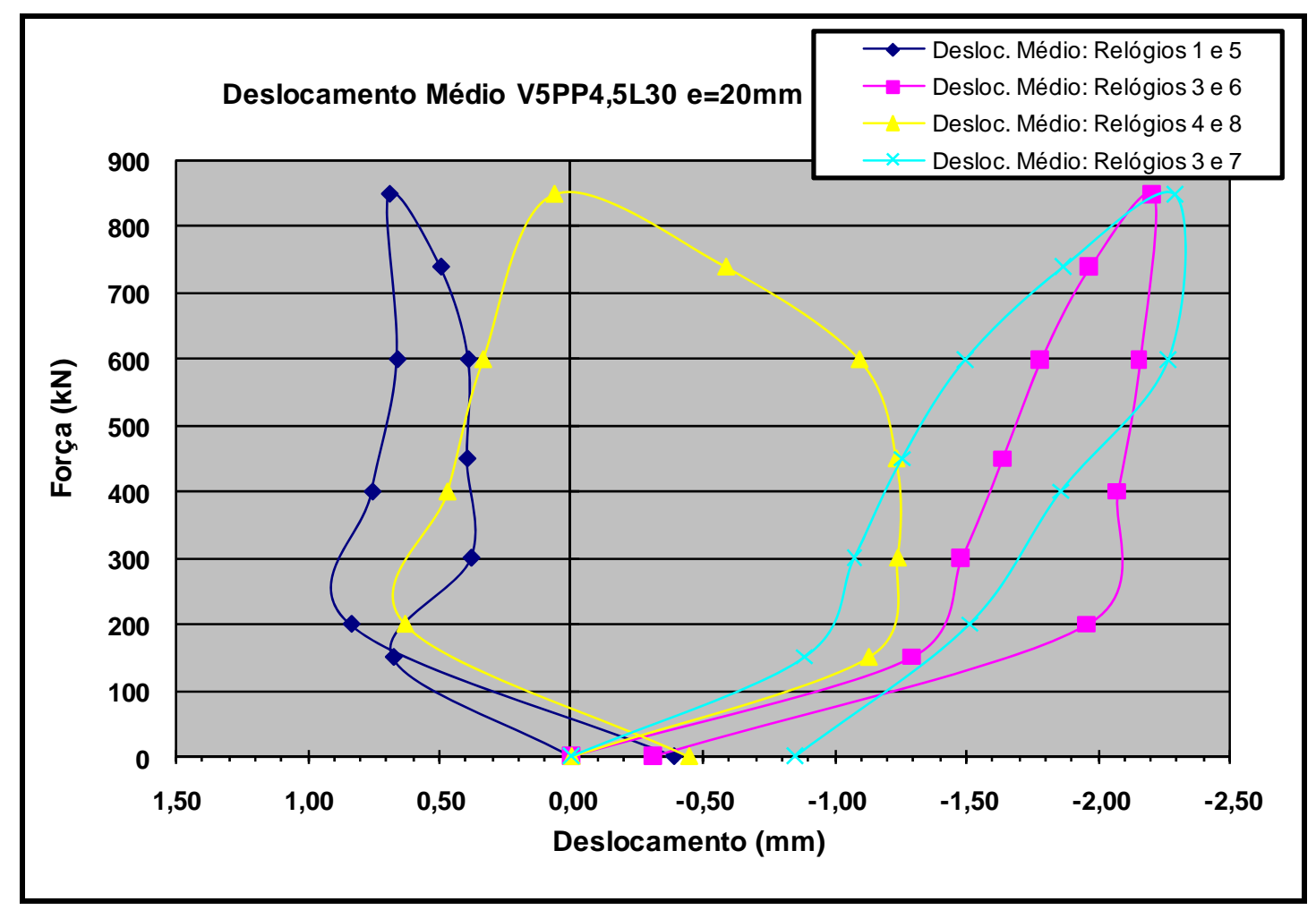

Figura 5.35: Deslocamento médio para o traço V5PP4,5L30 e=20mm.

$\checkmark$ Rotações nos Apoios: Nas figuras 5.36 e 5.37 são apresentados os resultados das rotações nos apoios para as almofadas com espessura de $20 \mathrm{~mm}$. 


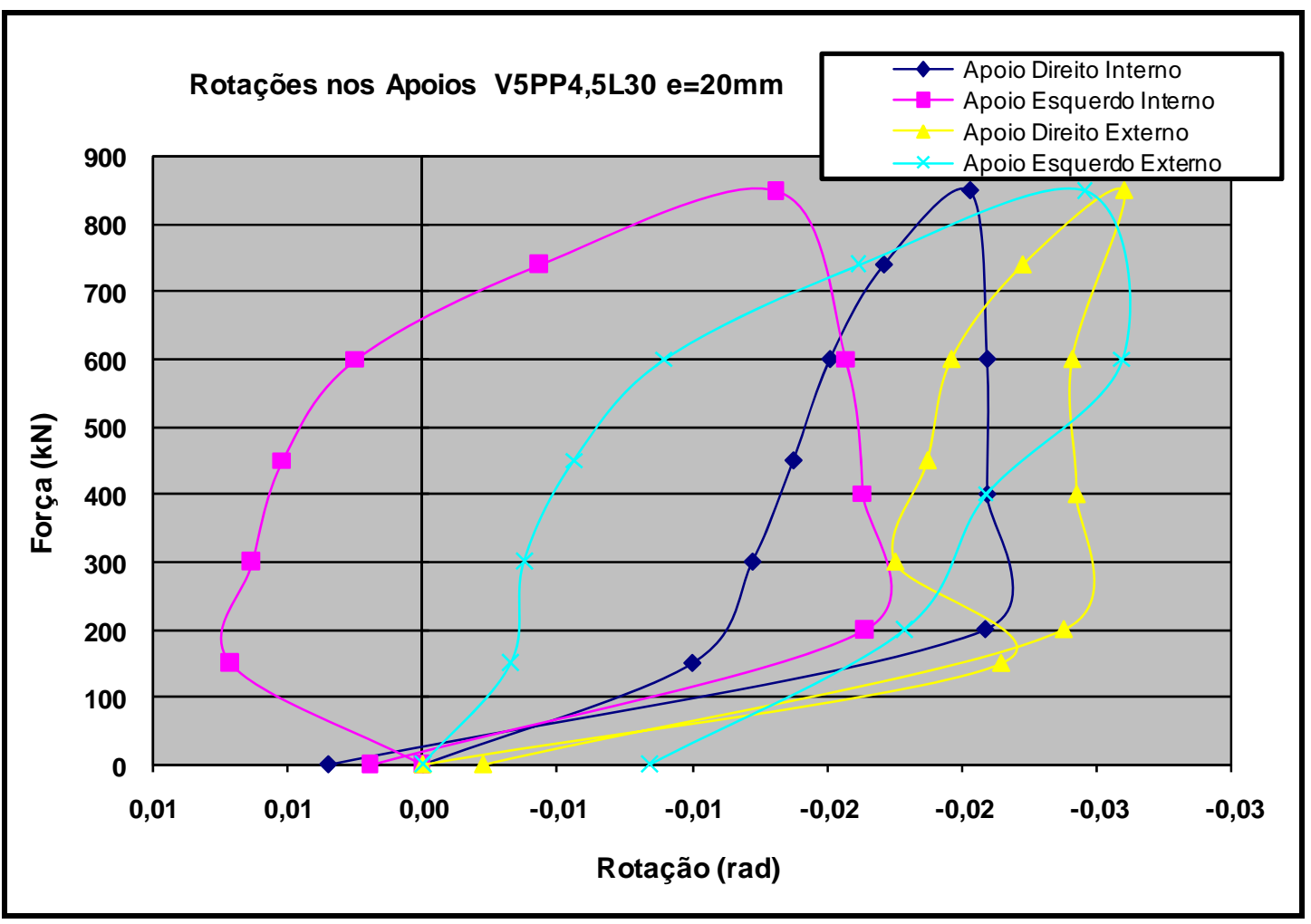

Figura 5.36: Rotações nos apoios para o traço V5PP4,5L30 e=20mm.

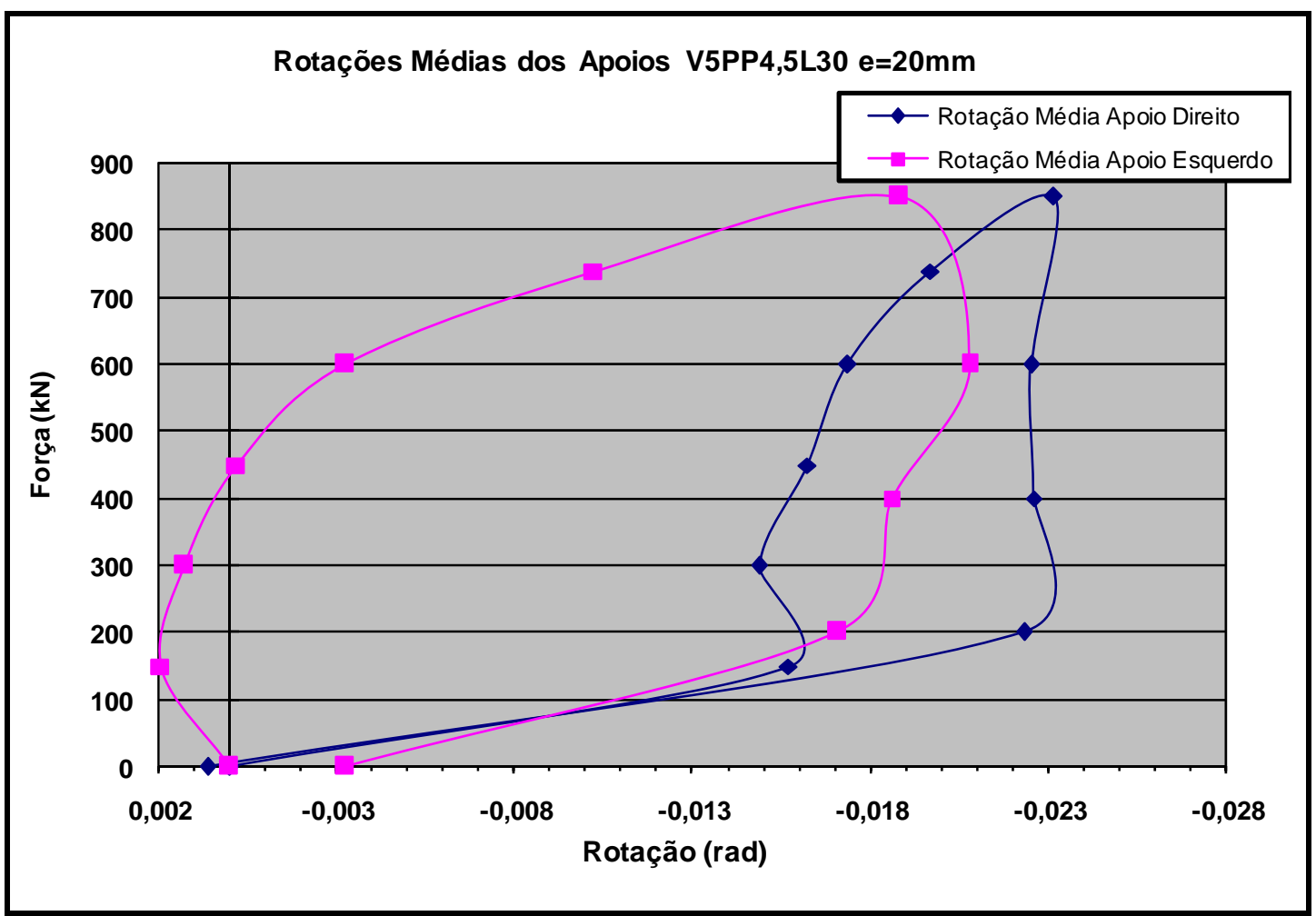

Figura 5.37: Rotações médias dos apoios para o traço V5PP4,5L30 e=20mm. 


\section{V10PP4L30:}

\section{1) Almofada com espessura de $10 \mathrm{~mm}$ e excentricidade de $6,0 \mathrm{~cm}$ :}

$\checkmark$ Deslocamento nos Apoios: A Figura 5.38 traz os deslocamentos médios nos apoios para almofadas com espessura de $10 \mathrm{~mm}$.

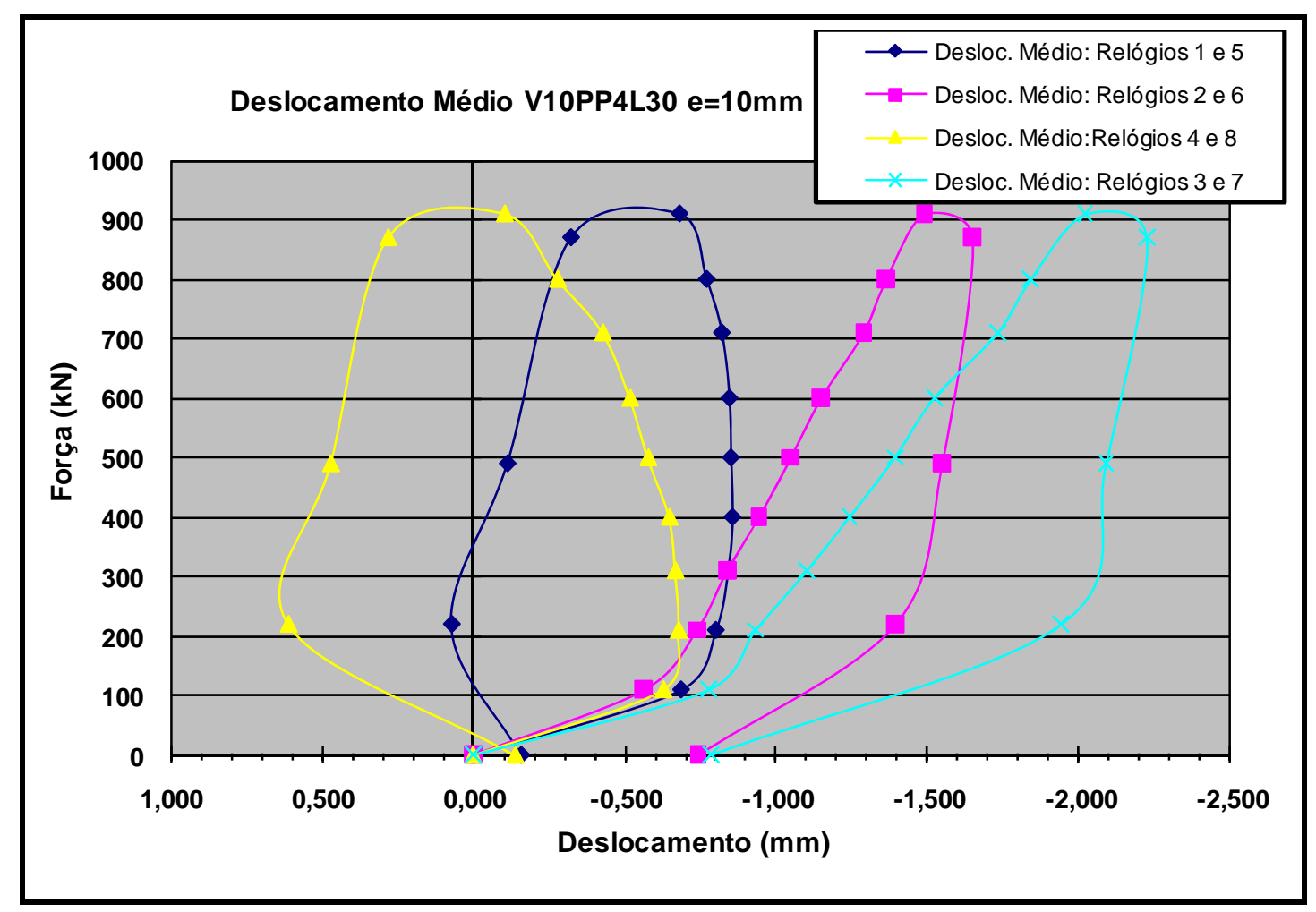

Figura 5.38: Deslocamento médio para o traço V10PP4L30 e=10mm.

$\checkmark$ Rotações nos Apoios: Nas figuras 5.39 e 5.40 são apresentados os resultados das rotações nos apoios para as almofadas com espessura de $10 \mathrm{~mm}$. 


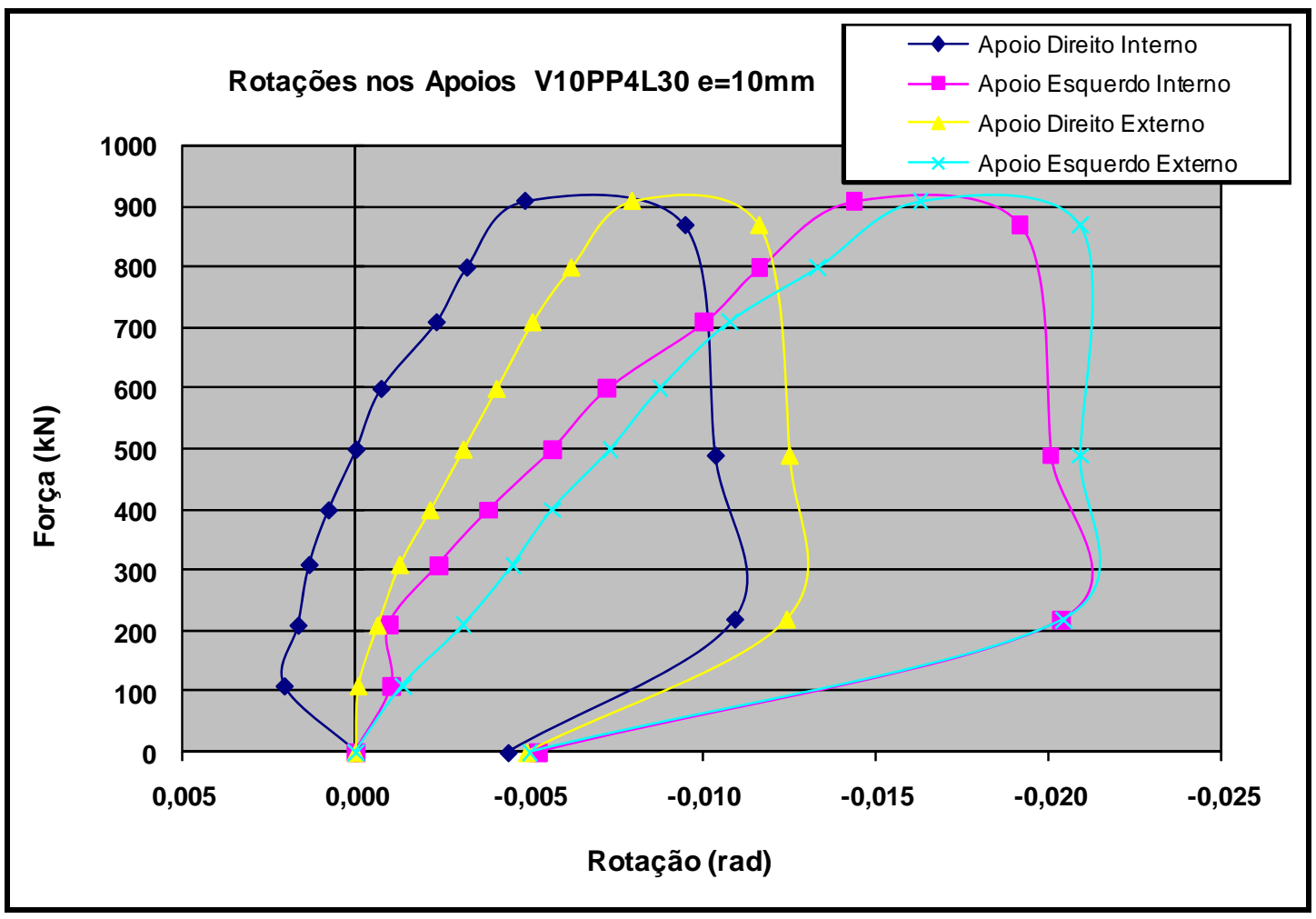

Figura 5.39: Rotações nos apoios para o traço V10PP4L30 e=10mm.

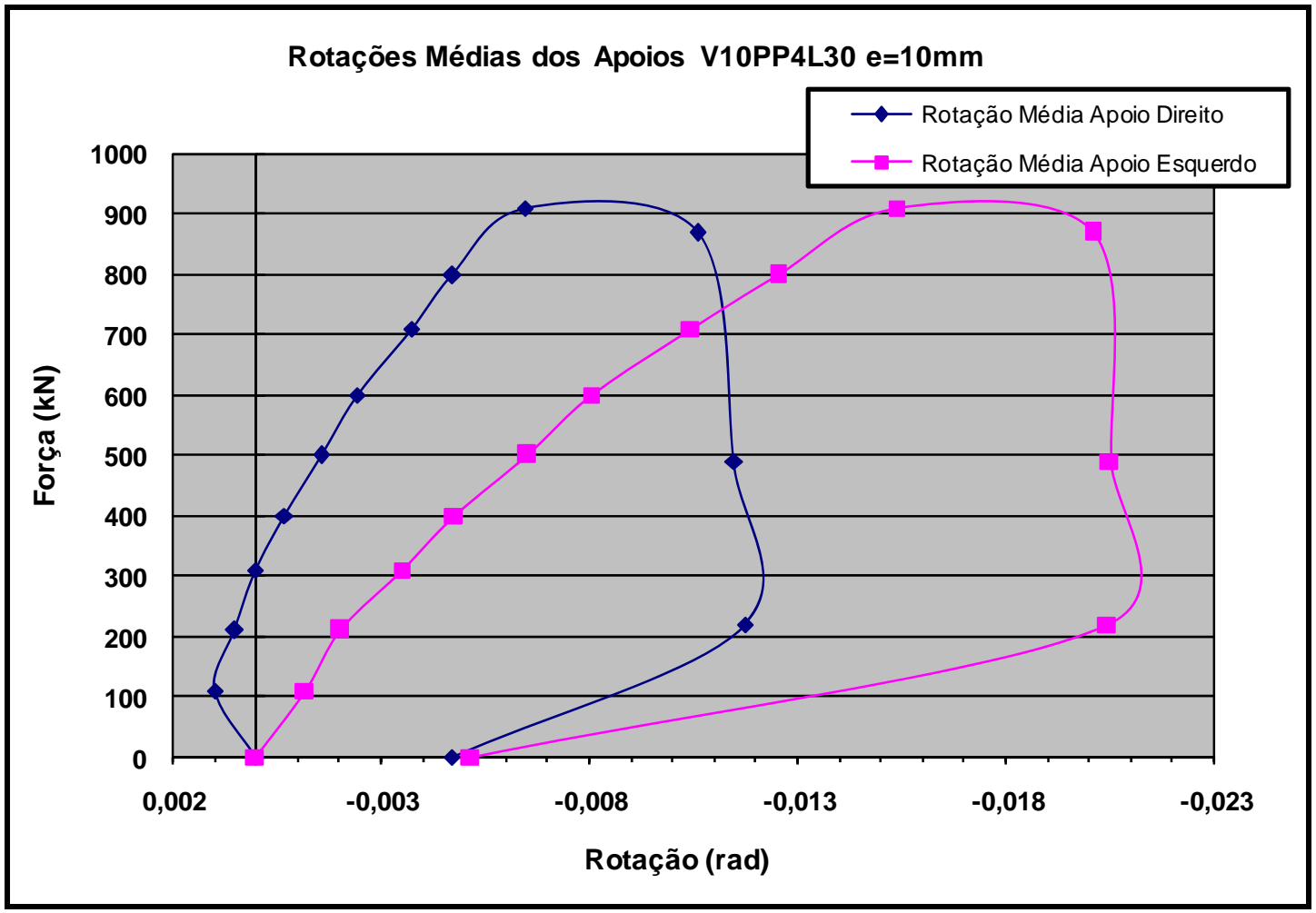

Figura 5.40: Rotações médias dos apoios para o traço V10PP4L30 e=10mm. 


\section{2) Almofada com espessura de $20 \mathrm{~mm}$ e excentricidade de $5,5 \mathrm{~cm}$ :}

$\checkmark$ Deslocamento nos Apoios: A Figura 5.41 traz os deslocamentos médios nos apoios para almofadas com espessura de $20 \mathrm{~mm}$.

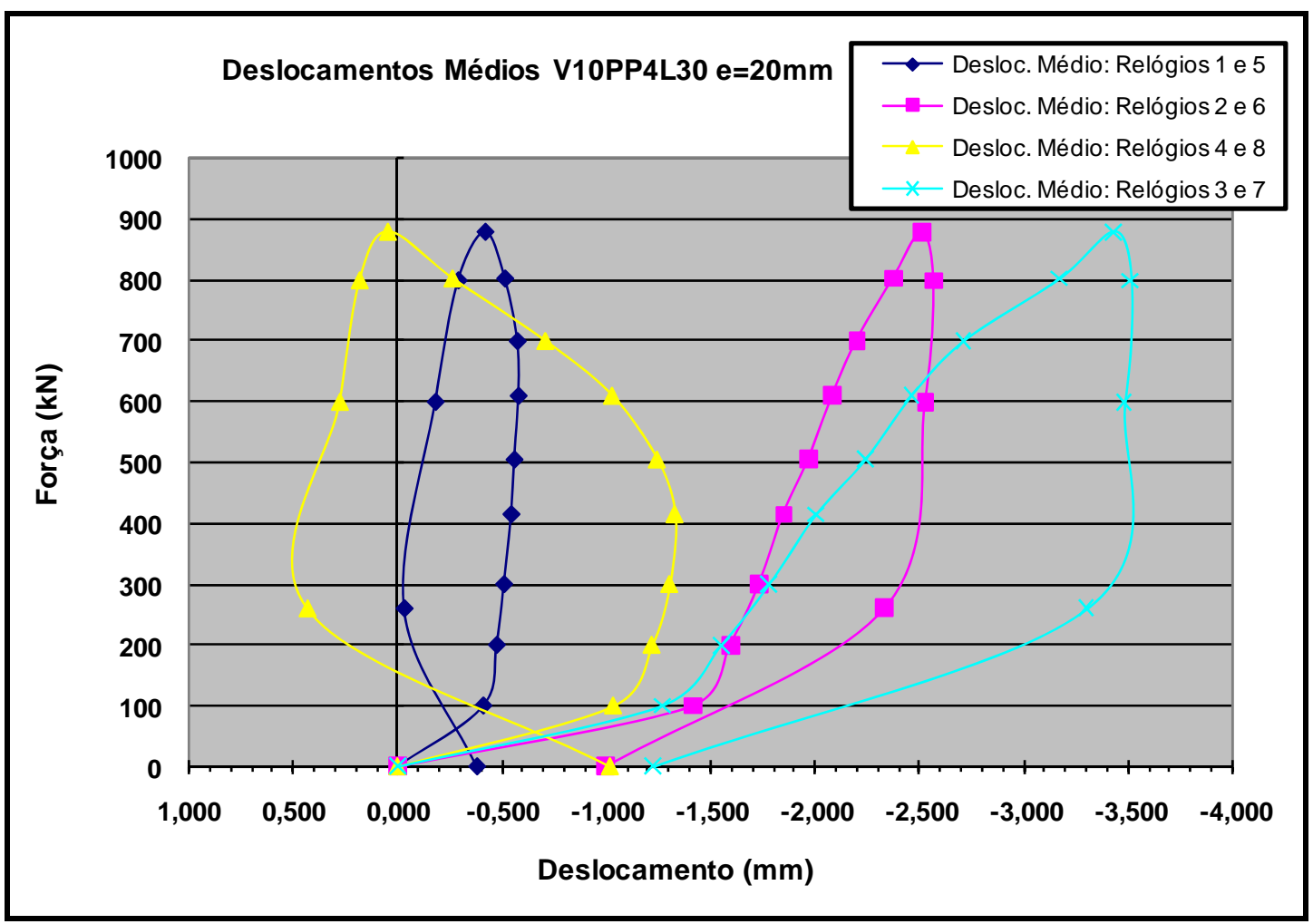

Figura 5.41: Deslocamento médio para o traço V10PP4L30 e=20mm.

$\checkmark$ Rotações nos Apoios: Nas figuras 5.42 e 5.43 são apresentados os resultados das rotações nos apoios para as almofadas com espessura de $20 \mathrm{~mm}$. 


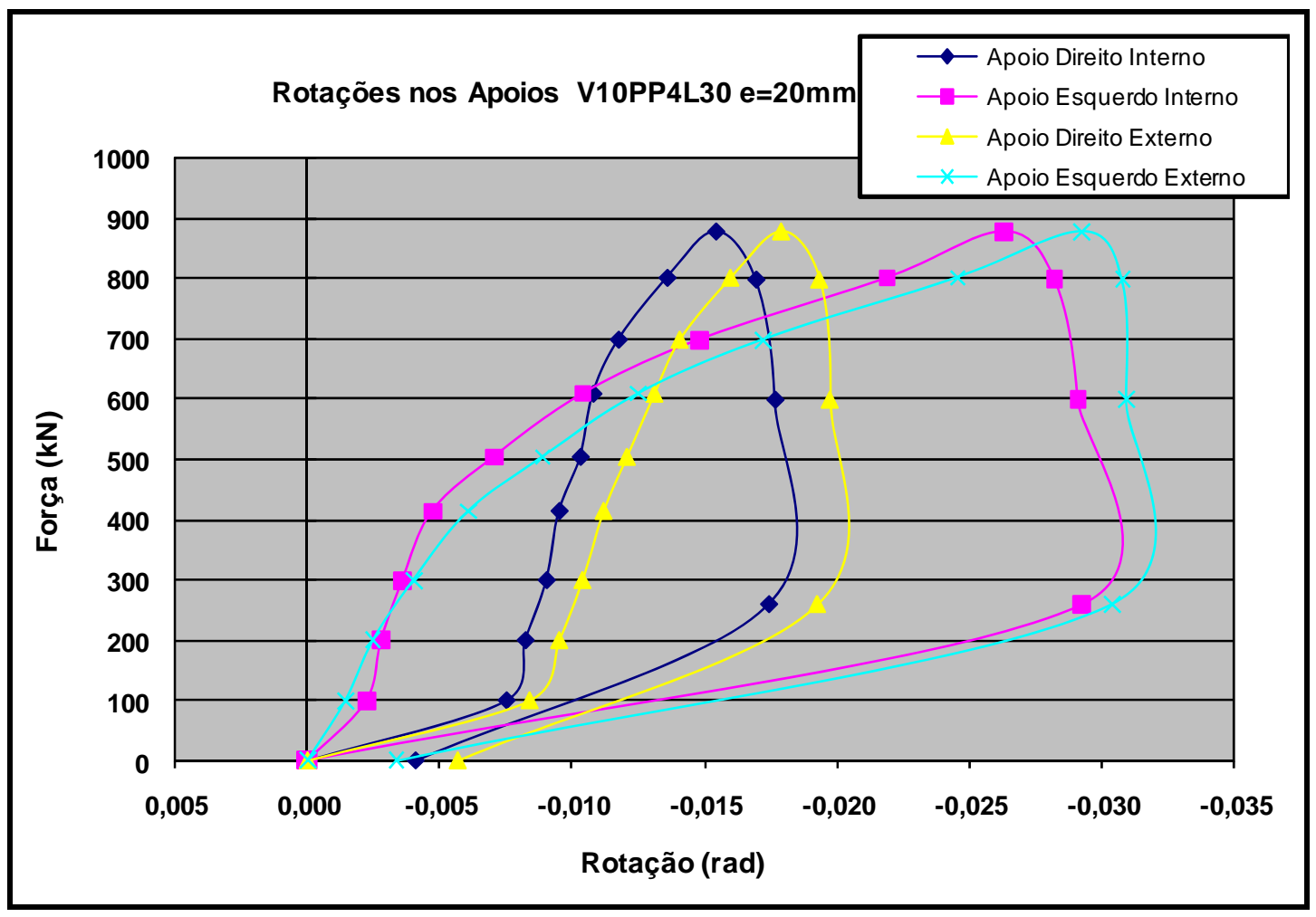

Figura 5.42: Rotações nos apoios para o traço V10PP4L30 e=20mm.

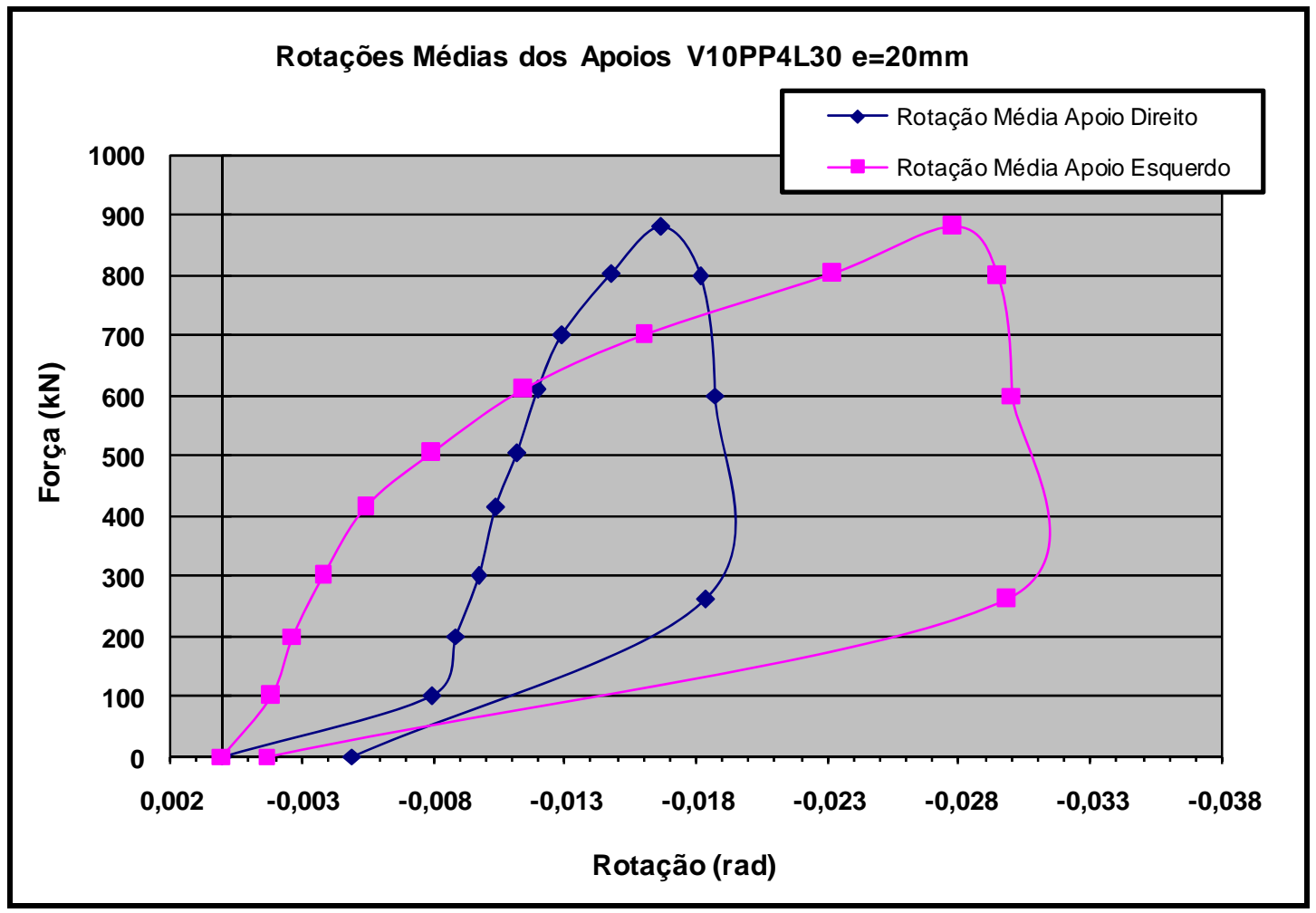

Figura 5.43: Rotações médias dos apoios para o traço V10PP4L30 e=20mm. 


\section{V15PP3,5L30:}

\section{1) Almofada com espessura de $10 \mathrm{~mm}$ e excentricidade de $6,0 \mathrm{~cm}$ :}

$\checkmark$ Deslocamento nos Apoios: A Figura 5.44 traz os deslocamentos médios nos apoios para almofadas com espessura de $10 \mathrm{~mm}$.

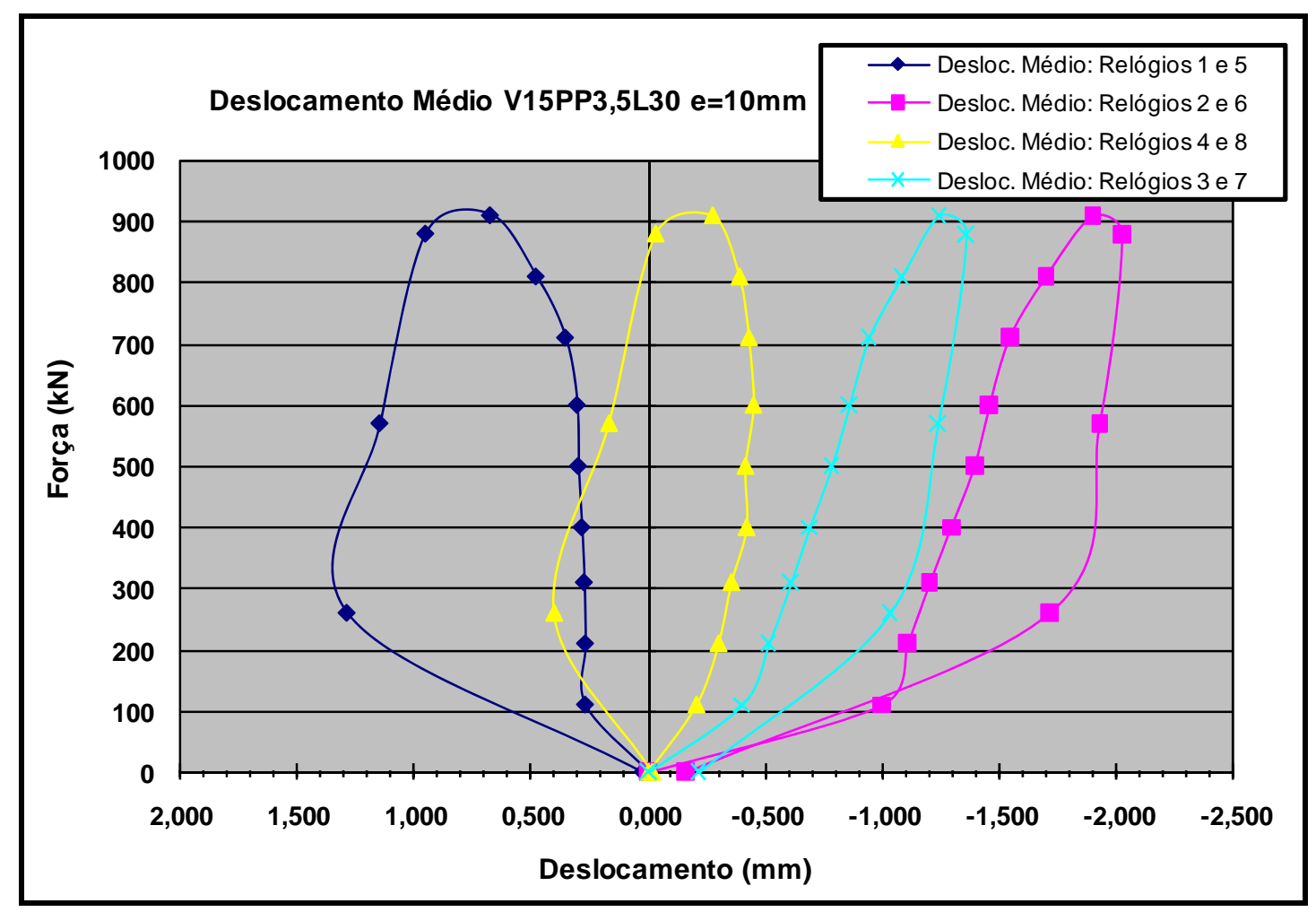

Figura 5.44: Deslocamento médio para o traço V15PP3,5L30 e=10mm.

$\checkmark$ Rotações nos Apoios: Nas figuras 5.45 e 5.46 são apresentados os resultados das rotações nos apoios para as almofadas com espessura de $10 \mathrm{~mm}$. 


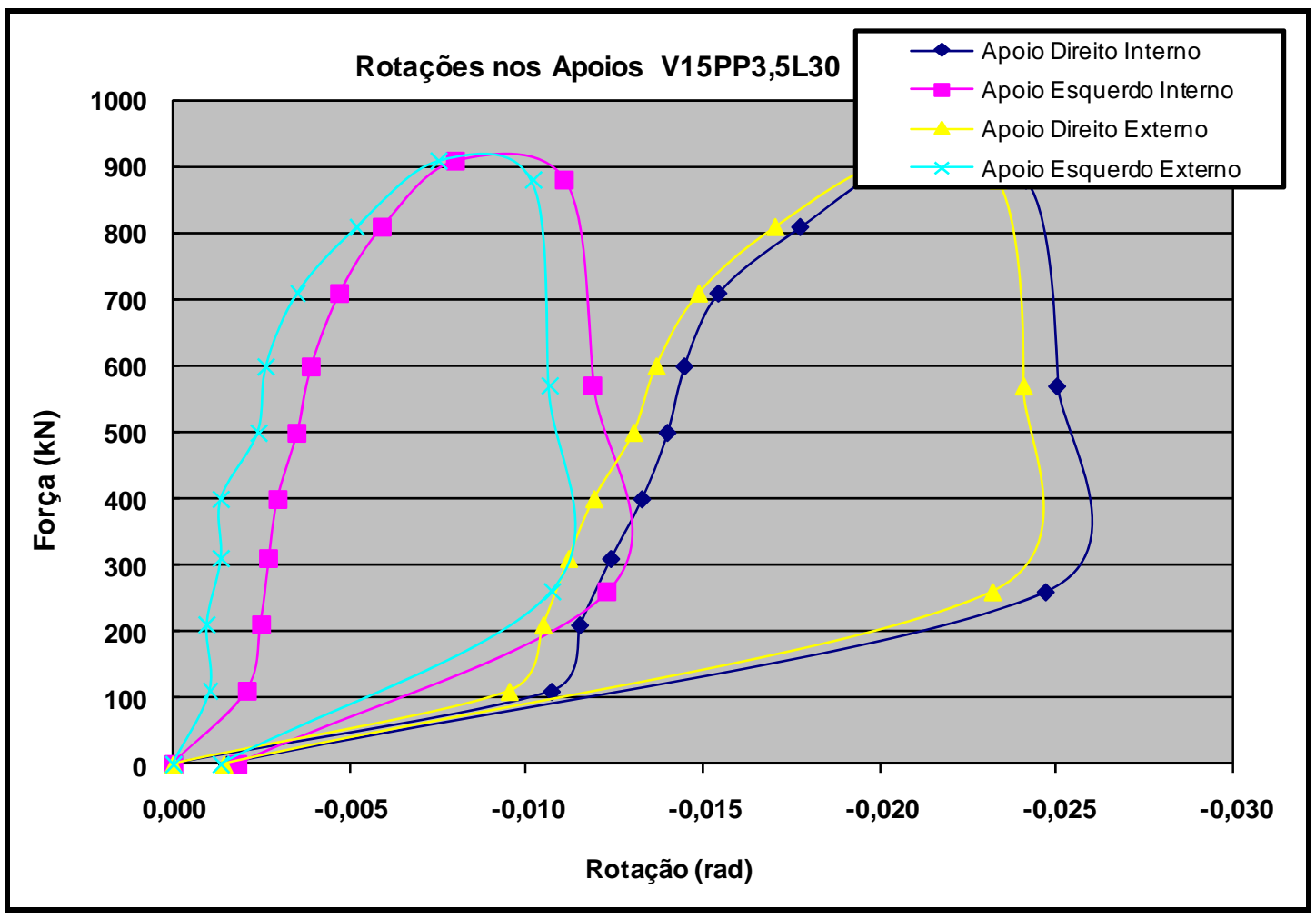

Figura 5.45: Rotações nos apoios para o traço V15PP3,5L30 e=10mm.

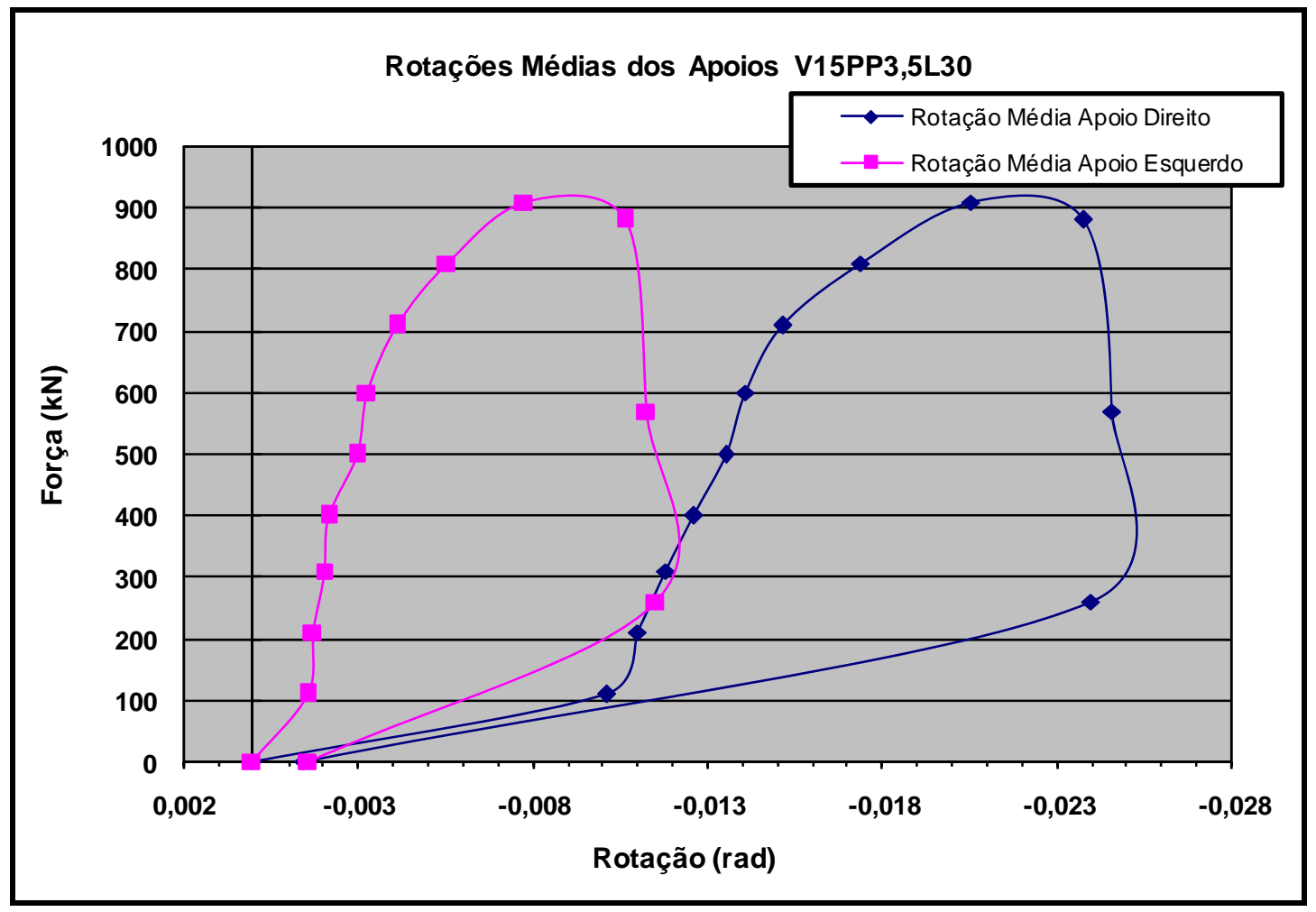

Figura 5.46: Rotações médias dos apoios para o traço V15PP3,5L30 e=10mm. 


\section{2) Almofada com espessura de $20 \mathrm{~mm}$ e excentricidade de 5,5cm:}

$\checkmark$ Deslocamento nos Apoios: A Figura 5.47 traz os deslocamentos médios nos apoios para almofadas com espessura de $20 \mathrm{~mm}$.

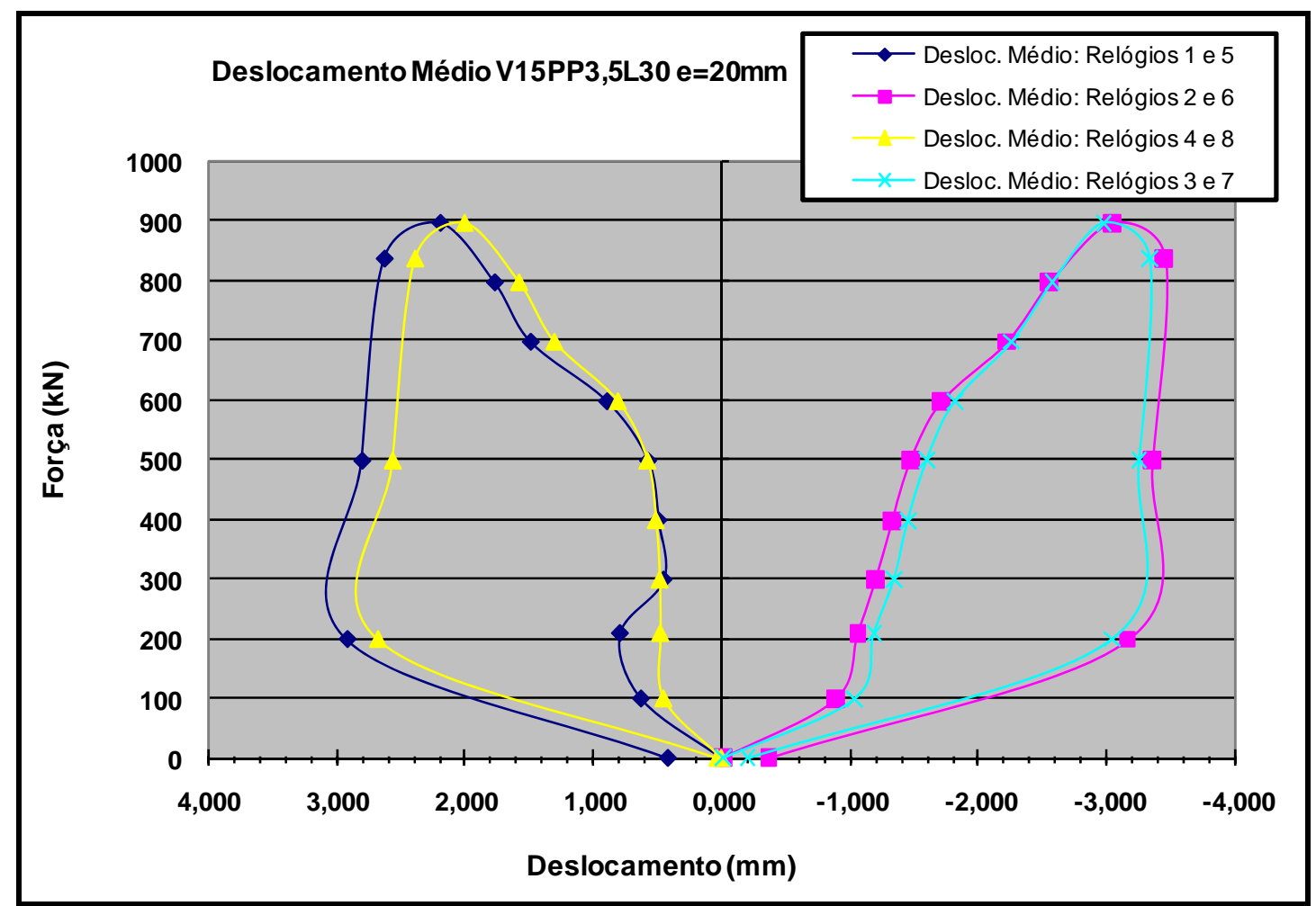

Figura 5.47: Deslocamento médio para o traço V15PP3,5L30 e=20mm.

$\checkmark$ Rotações nos Apoios: Nas figuras 5.48 e 5.49 são apresentados os resultados das rotações nos apoios para as almofadas com espessura de $20 \mathrm{~mm}$. 


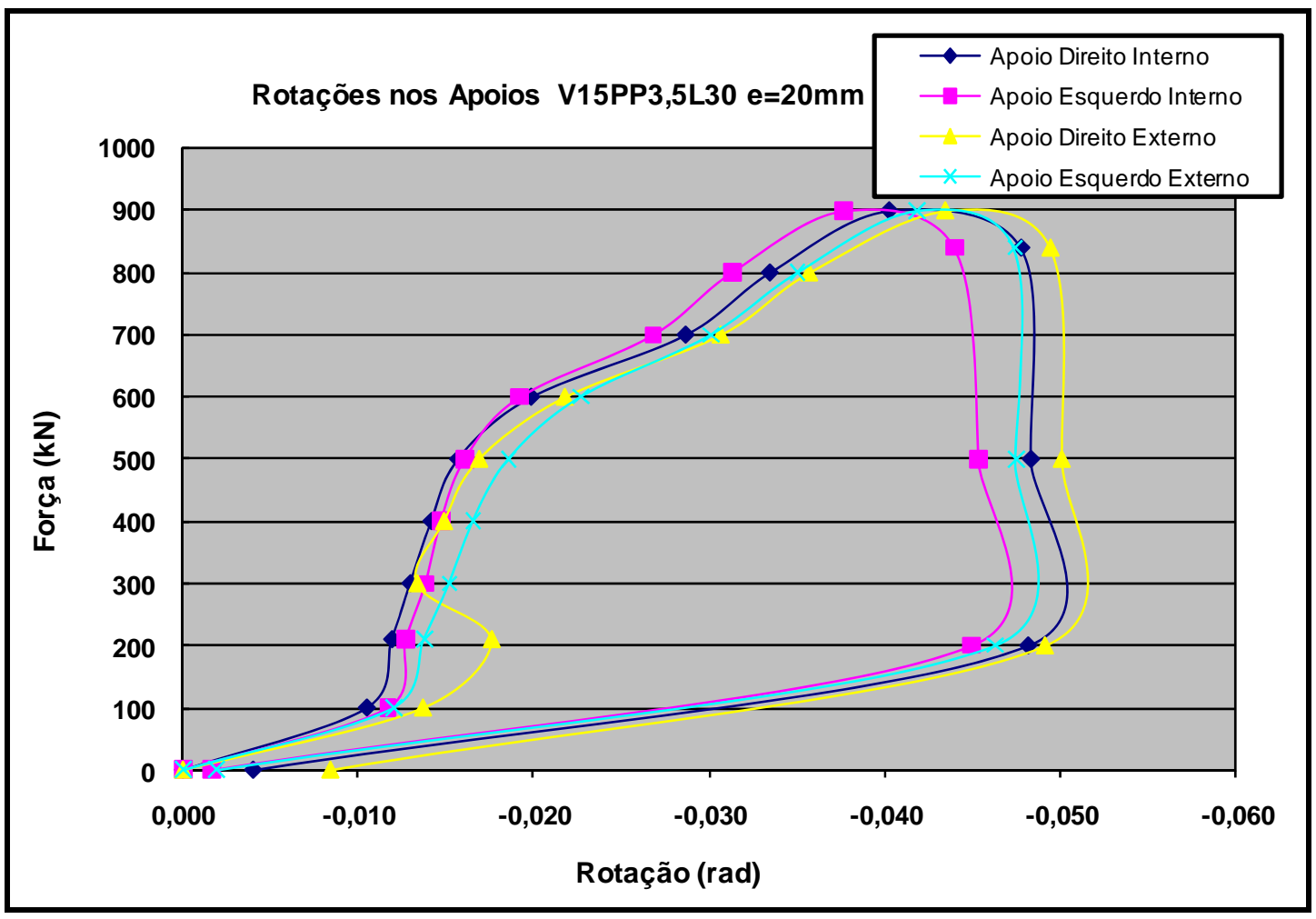

Figura 5.48: Rotações nos apoios para o traço V15PP3,5L30 e=20mm.

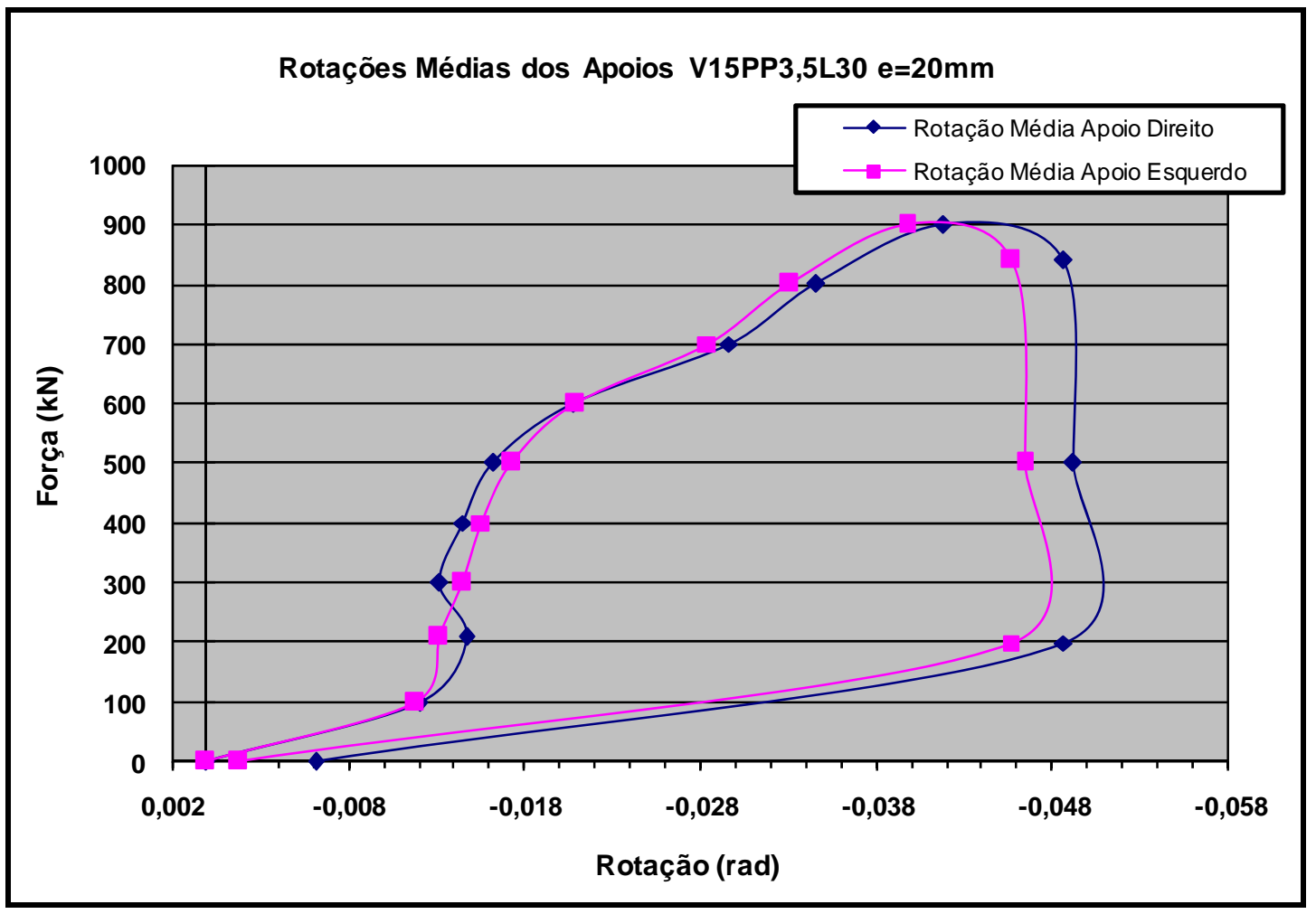

Figura 5.49: Rotações médias dos apoios para o traço V15PP3,5L30 e=20mm. 
Pela análise dos deslocamentos e giros apresentados por cada traço e espessura de almofadas, pode-se concluir que as almofadas com 20mm de espessura apresentaram grande capacidade de giro, mas também valores menos uniformes para os deslocamentos e rotações sofridas e, apresentando sempre descolamento da superfície externa da chapa em relação à almofada. Isto pode ser visualizado na Figura 5.47, onde os deslocamentos sofridos nas porções do apoio se repetem tanto para os relógios posicionados mais ao meio da placa como para os relógios mais externos, que não poderiam apresentar deslocamentos com sinais positivos. Acredita-se que esta inversão pronunciada nestes valores advém da espessura elevada da almofada, na qual o carregamento excêntrico acaba provocando um maior afundamento na porção mais interna do apoio, provocando concentração de tensões nessa região. Isso acarreta um giro maior na porção mais externa do apoio com descolamento desta face da chapa em relação à almofada, como mostra a Figura 5.50 .

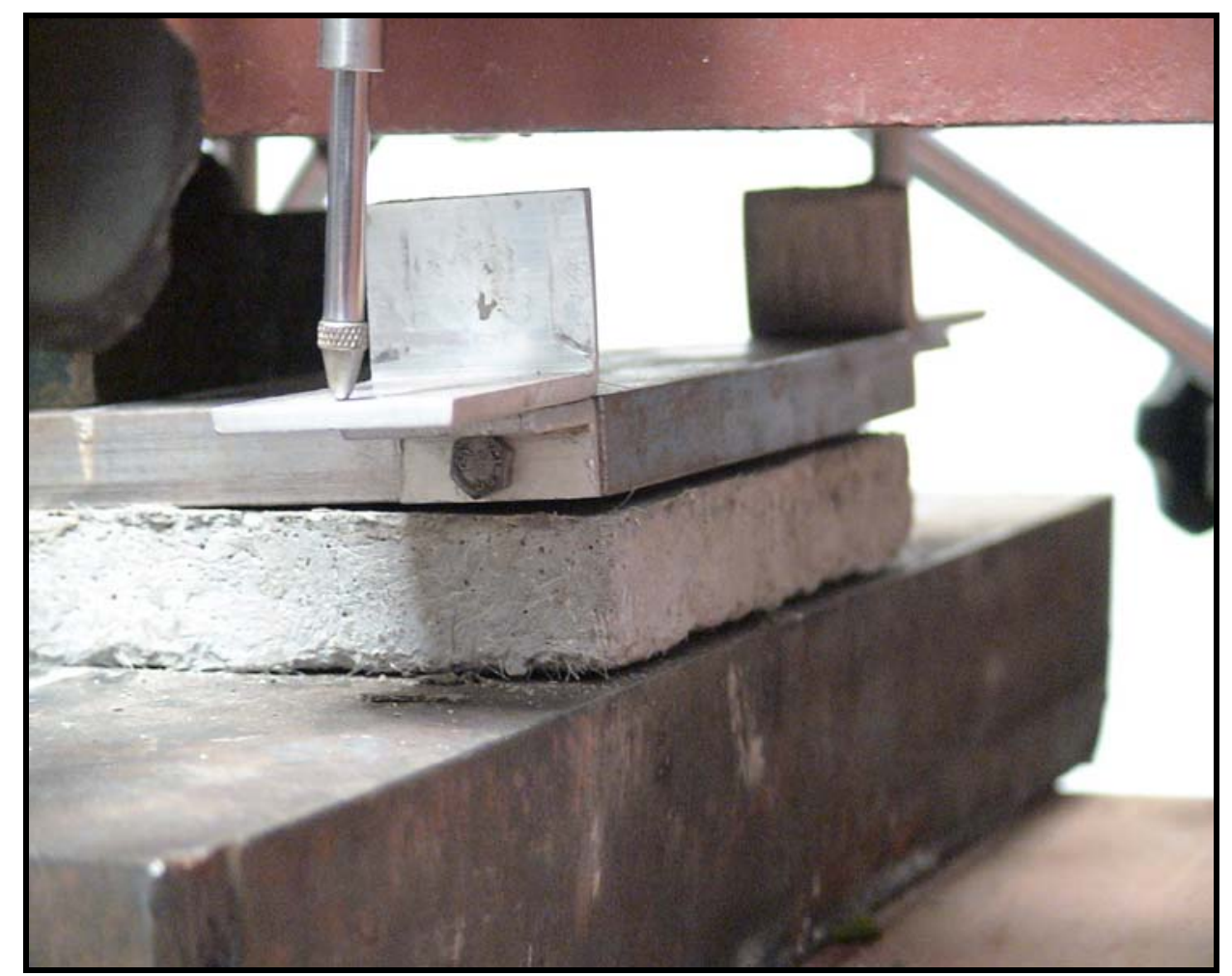

Figura 5.50: Descolamento entre a chapa metálica e almofada de 20mm.

Ocorre também, para as almofadas de $20 \mathrm{~mm}$ de espessura, um padrão de fissuração elevado, decorrente da concentração de tensões em determinadas porções destas. Este fato é prejudicial para o desempenho em situações de uso do compósito, não sendo 
recomendável sua ocorrência. Este padrão de fissuração está apresentado na Figura 5.51 .

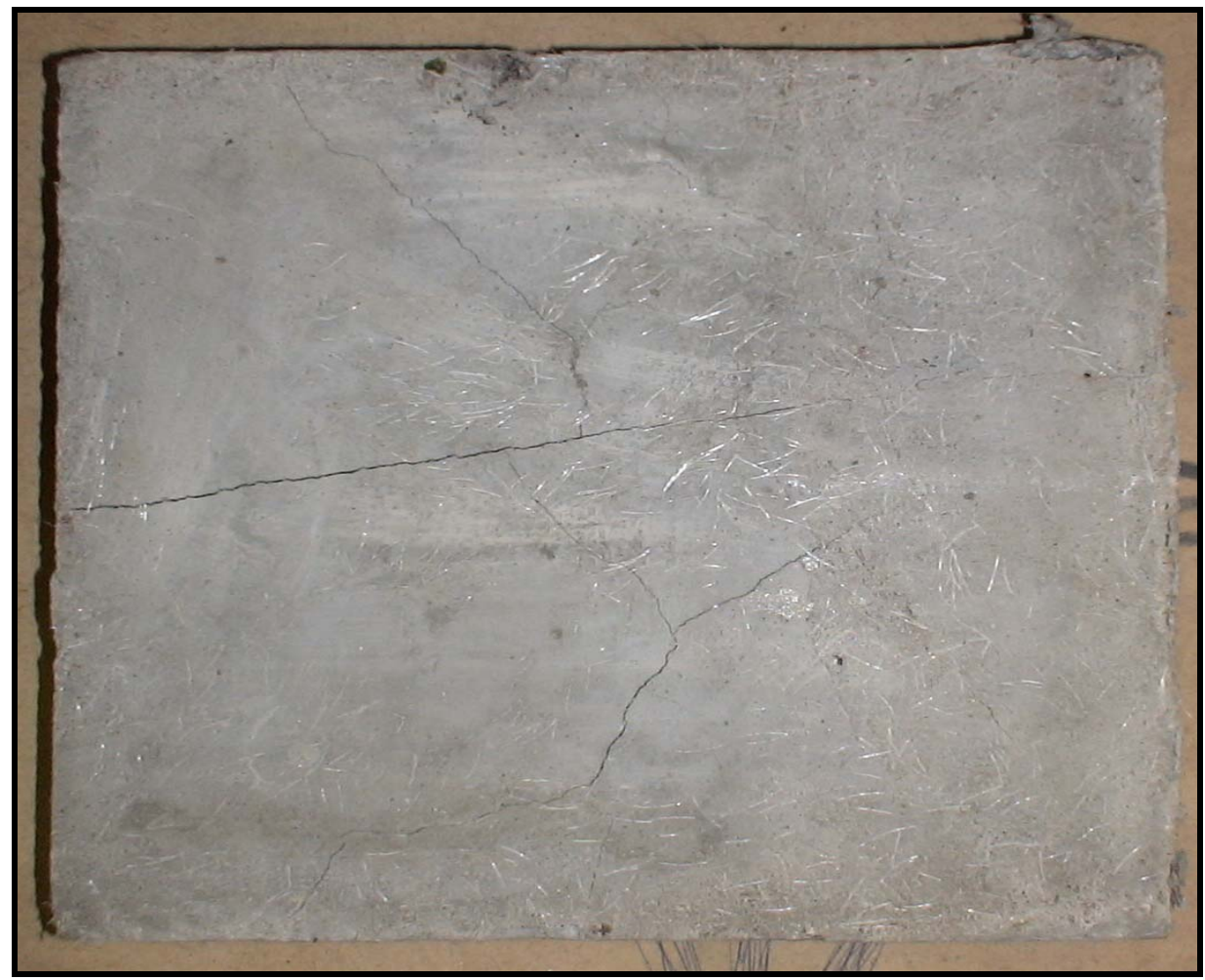

Figura 5.51: Fissuras após ensaio de rotação em almofada de $20 \mathrm{~mm}$.

Para as almofadas de $10 \mathrm{~mm}$ de espessura, obtiveram-se resultados com um padrão melhor de desempenho. Os giros máximos foram calculados aceitando-se valores positivos de até 0,5mm de deslocamento dos relógios de extremidade. Estes valores geraram descolamentos quase imperceptíveis, com pequena concentração de tensão na almofada, não sendo prejudiciais ao seu desempenho.

No traço com 5\% de vermiculita, sua maior rigidez e menor deformabilidade provocaram um descolamento da extremidade da chapa metálica em relação à almofada, como pode ser visualizado pelos deslocamentos apresentados na Figura 5.32. Esse descolamento foi responsável pelos valores elevados de capacidade de rotação para esse traço. No apoio onde o descolamento foi menor, a capacidade de giro apresentada também foi bem menor. Em situações normais, o valor adotado para a capacidade de giro deste traço seria de 0,01 rad, apresentado pela Figura 5.34 no apoio direito. 
Para o traço com 10\% de vermiculita, pode-se visualizar um padrão mais homogêneo dos deslocamentos, existindo um descolamento da chapa em relação à almofada, mas este se pronuncia na fase de descarregamento da chapa metálica (Figura 5.38). As figuras 5.39 e 5.40 mostram que os valores máximos de rotação suportados por esse traço se apresentam da ordem de 0,02 rad, o que se considera como um valor adequado de capacidade de rotação.

O traço com $15 \%$ de vermiculita já apresentou valores de capacidade de rotação da ordem de 0,025 rad (Figura 5.46), como se esperava, o aumento da quantidade de vermiculita aumentou a deformabilidade do material. Ocorreu também uma inversão dos valores de deslocamento relativo de um dos apoios, acarretando um descolamento da extremidade da chapa em relação à almofada. Como os valores experimentais se apresentaram com deslocamentos positivos maiores que $0,5 \mathrm{~mm}$, houve uma grande concentração de tensão na almofada e, esse valor de giro de 0,025 rad não pode ser considerado, com segurança, como o valor da capacidade de rotação para este traço.

Um comparativo da capacidade de giro entre as almofadas com 10mm de espessura está mostrado na Figura 5.52.

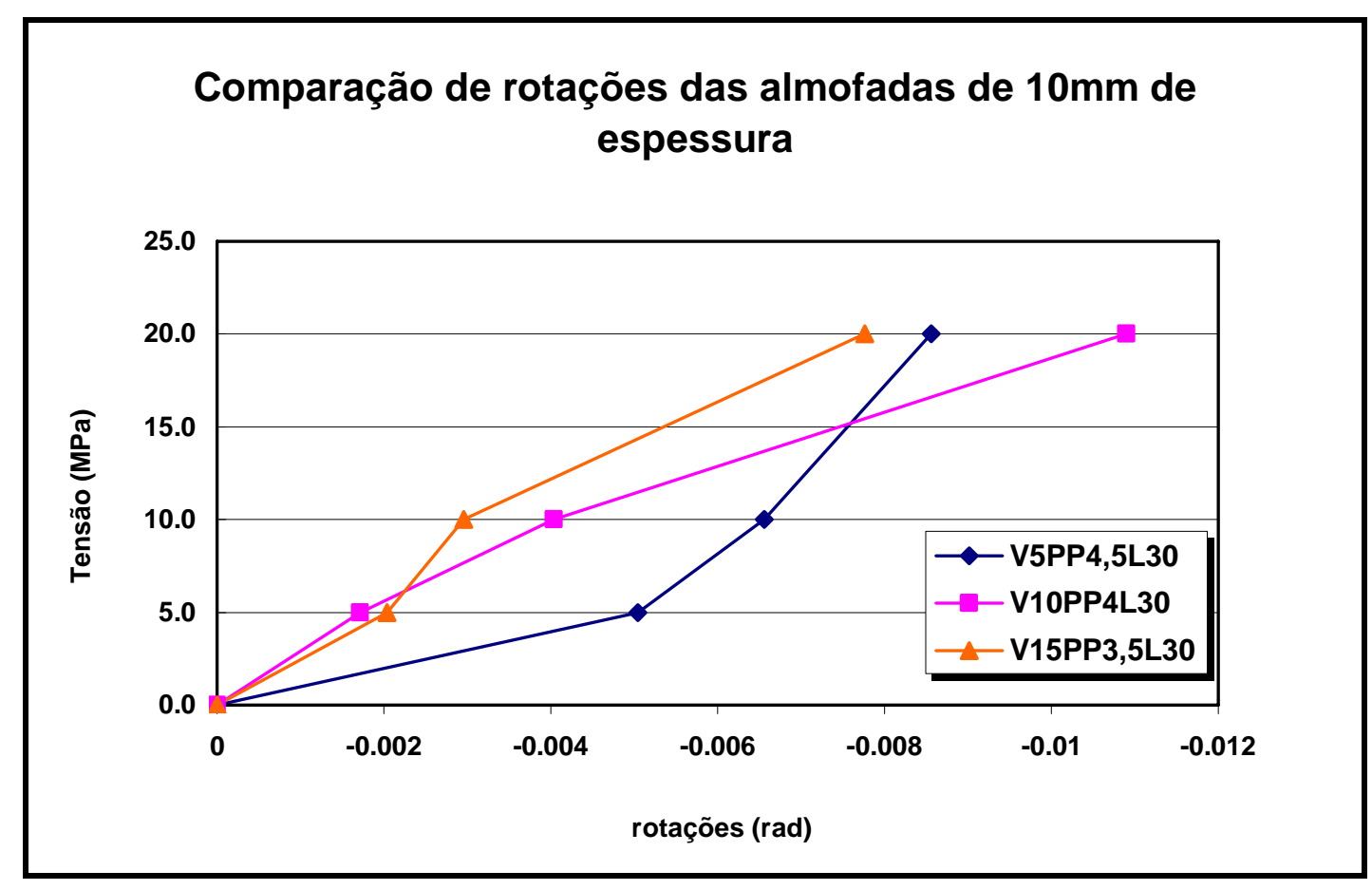

Figura 5.52: Comparação de rotações para as almofadas de 10mm de espessura. 
Na Figura 5.52, estão mostradas as leituras de rotações estritamente positivas, sem que houvesse concentração de tensões em certas regiões das almofadas, devido ao descolamento, mesmo que em pequena escala, entre esta e a chapa metálica. Para o cálculo da capacidade máxima de rotação das almofadas foram aceitos valores de deslocamento positivo de até $0,5 \mathrm{~mm}$, como dito anteriormente. Os descolamentos existentes e a concentração de tensões neste caso, não comprometeram a integridade das almofadas, ao contrário das almofadas de $20 \mathrm{~mm}$.

As rotações apresentadas na Figura 5.52 não se comportaram da maneira esperada. Com o aumento da quantidade de vermiculita acredita-se que o material aumente sua capacidade de rotação. O que pode explicar esse comportamento fora do padrão para os traços com 5 e 10\% de vermiculita foi que, ocorreram problemas de leitura dos relógios num primeiro estágio de carregamento do ensaio. $\mathrm{O}$ ensaio teve que ser reiniciado, o que determinou a deformabilidade apresentada pelo traço com $5 \%$ de vermiculita para o início do carregamento.

Para níveis de tensões maiores que 5,0MPa, o que se observa é um maior enrijecimento da almofada com 5\% de vermiculita, que pode ser comprovado pela taxa de evolução das rotações a partir deste nível de tensões. Deste ponto em diante, os traços começam a ter um comportamento mais próximo do esperado. Lembrando que, a taxa de evolução da rotação para os traços com $10 \%$ e $15 \%$ de vermiculita estão invertidas, provavelmente, devido a um carregamento e descarregamento nas almofadas com $10 \%$ de vermiculita.

Outro ponto importante a ser ressaltado é que, acredita-se que a capacidade de rotação das almofadas é maior que os valores obtidos na Figura 5.52. A configuração de aplicação dos carregamentos apresentou-se muito instável. As almofadas de 10mm, mesmo apresentando concentração de tensões se mostraram sem grande danificação aparente e sem fissurações em grande quantidade e em padrões preocupantes. Uma melhoria na execução do ensaio pode acarretar valores maiores e mais confiáveis de capacidade de rotação.

Para os valores de rotações verificados em resultados de cálculos de vigas utilizadas em situações práticas, a capacidade de rotação das almofadas se apresentou bem maior do 
que as solicitações calculadas. Os valores calculados para efetuar uma comparação foram o de uma viga de ponte rolante existente no laboratório de estruturas, cujos dados serão apresentados na Figura 5.53 e uma viga de concreto armado simples com seção e solicitação apresentados na Figura 5.54.

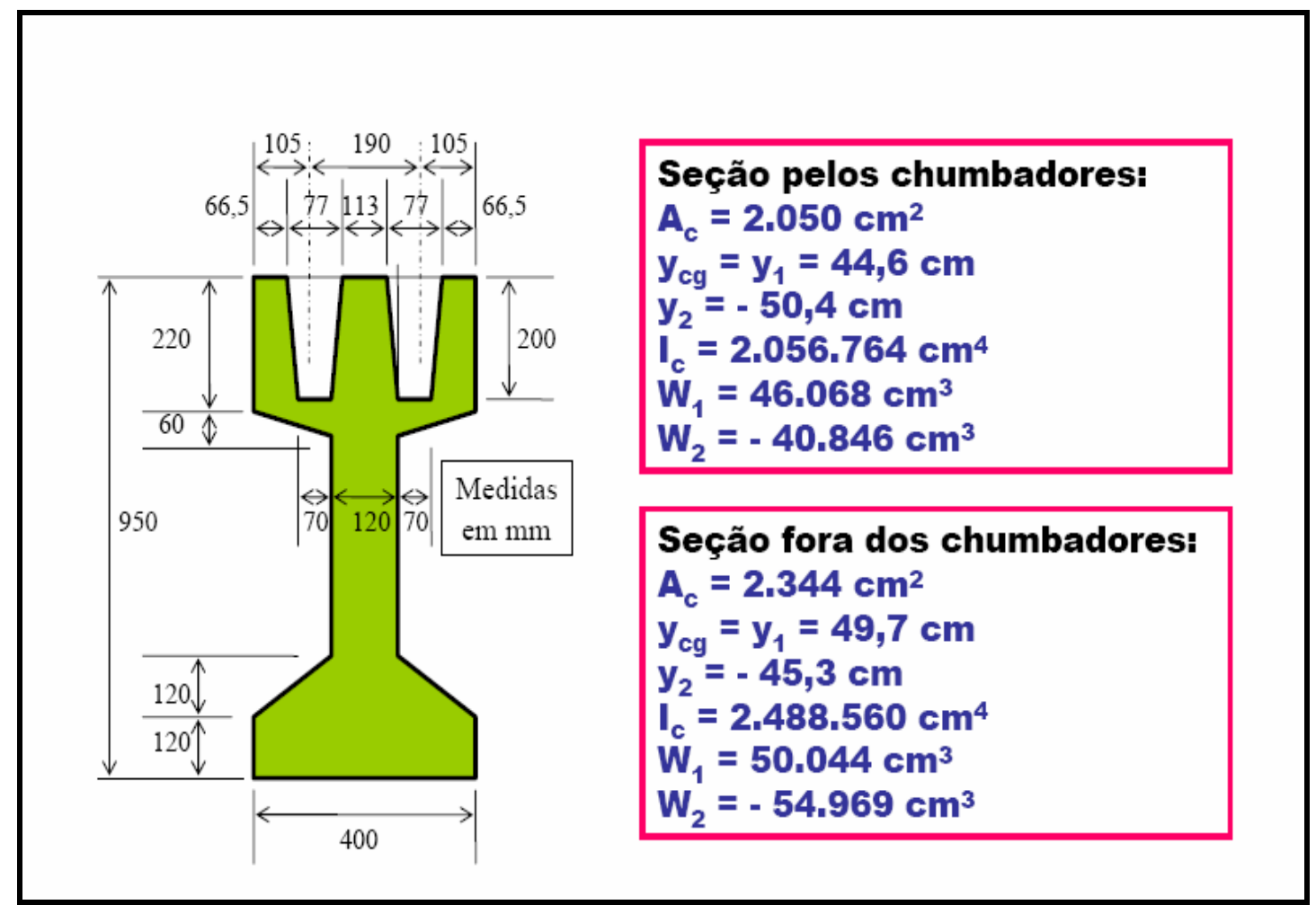

Figura 5.53: Viga de ponte rolante do laboratório de estruturas da EESC/USP.

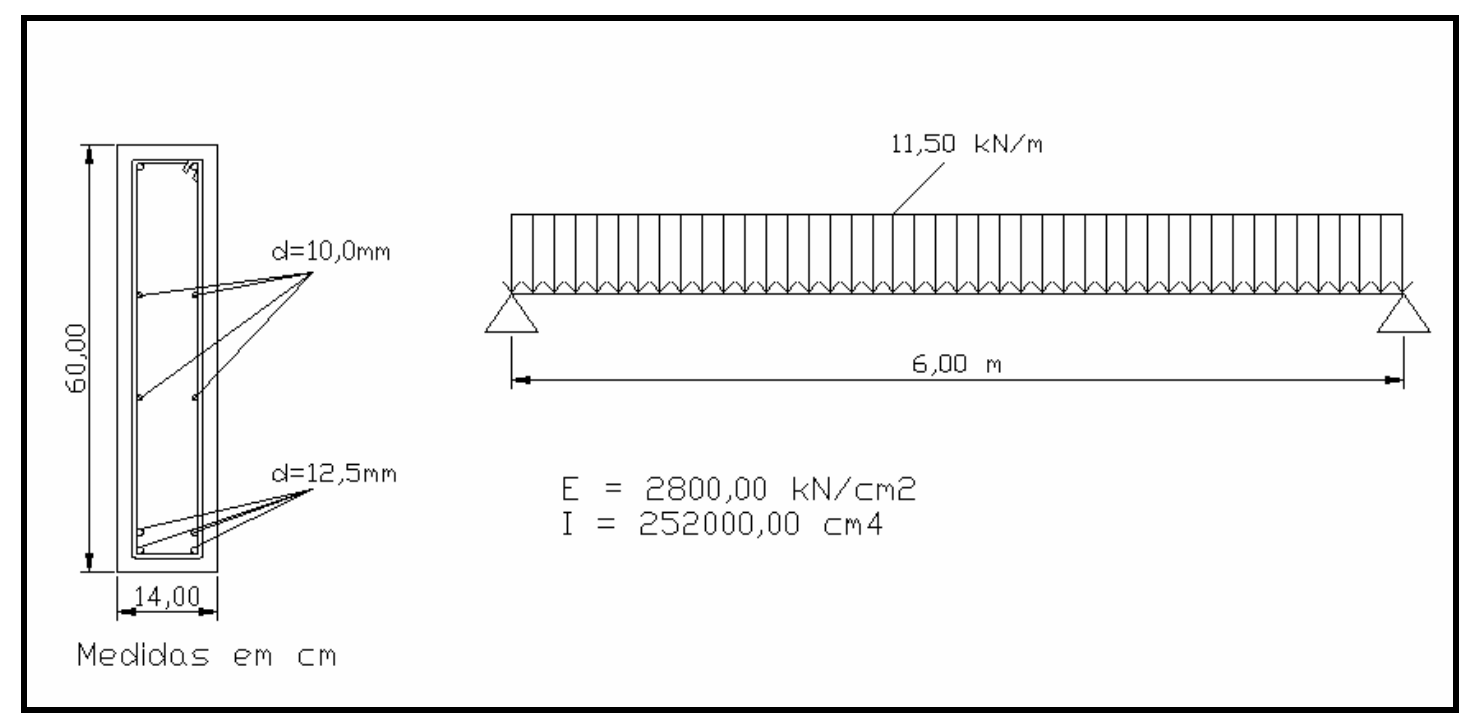

Figura 5.54: Viga de concreto armado idealizada. 
Para o caso da viga de concreto do Laboratório de Estruturas do departamento de Engenharia de Estruturas da EESC/USP, o giro máximo calculado através de tabelas adequadas para a situação de carregamento foi de $\mathbf{0 , 0 0 4}$ rad. As resultantes das forças aplicadas pela ponte rolante são de 69,0kN com distância de 3,60m. Considerando todas as ações atuando sobre a mesma e desconsiderando o efeito da protensão aplicada sobre a viga. A equação utilizada no cálculo da rotação para este caso é apresentada na equação 5.3.

$\theta_{\text {apoio }}=\frac{P a}{2 E I}(l-a)$

Sendo:

$\theta_{\text {apoio }}=$ giro nos apoios;

$P=$ forças resultantes aplicadas pela aplicadas pela ponte rolante;

$a=$ distância do apoio da viga às resultantes da ponte rolante;

$l=$ comprimento da viga;

$E I=$ rigidez da viga.

No caso da viga da Figura 5.56, pensou-se em uma viga usual de edifício de concreto armado considerando que esta estaria submetida a um carregamento elevado, com a consideração da rigidez efetiva desta da ordem de 30\% da rigidez da seção íntegra, devido ao processo de fissuração. Nestas condições a rotação máxima calculada foi de 0,005 rad. A rotação para este caso foi calculada segundo a equação 5.4.

$$
\theta_{\text {apoio }}=\frac{p l^{3}}{24 E I}
$$

Sendo:

$\theta_{\text {apoio }}=$ giro nos apoios;

$p=$ resultante do carregamento distribuído na viga;

$l=$ comprimento da viga;

$E I=$ rigidez da viga .

Tratando-se de concreto pré-moldado, no projeto dos aparelhos de apoio, as indicações de projeto aconselham adotar uma rotação inicial devido à imprecisão de montagem da ordem de 0,01 rad, segundo EL DEBS (2000). Se somarmos esta indicação de projeto 
aos valores obtidos nos cálculos, teremos rotações da ordem de $\mathbf{0 , 0 1 5} \mathbf{~ r a d}$, sendo este valor menor que a rotação obtida para as almofadas do compósito, sendo estas capazes de absorver as rotações ocasionadas por carregamentos usuais na prática.

\subsection{Ensaio de tenacidade ao fraturamento}

Como referido no capítulo 4, os ensaio de fraturamento objetivam a determinação de parâmetros relacionados à tenacidade flexional do compósito, a exemplo do limite de proporcionalidade da fase elástica do material, assim como as contribuições das fibras incorporadas, através da determinação das resistências residuais. Estes ensaios foram realizados somente no traço V10PP4L30 devido ao seu desempenho nos resultados dos ensaios realizados anteriormente.

Na Figura 5.55 são apresentadas as curvas de deslocamento vertical da linha de carga para as quatro amostras estudadas.

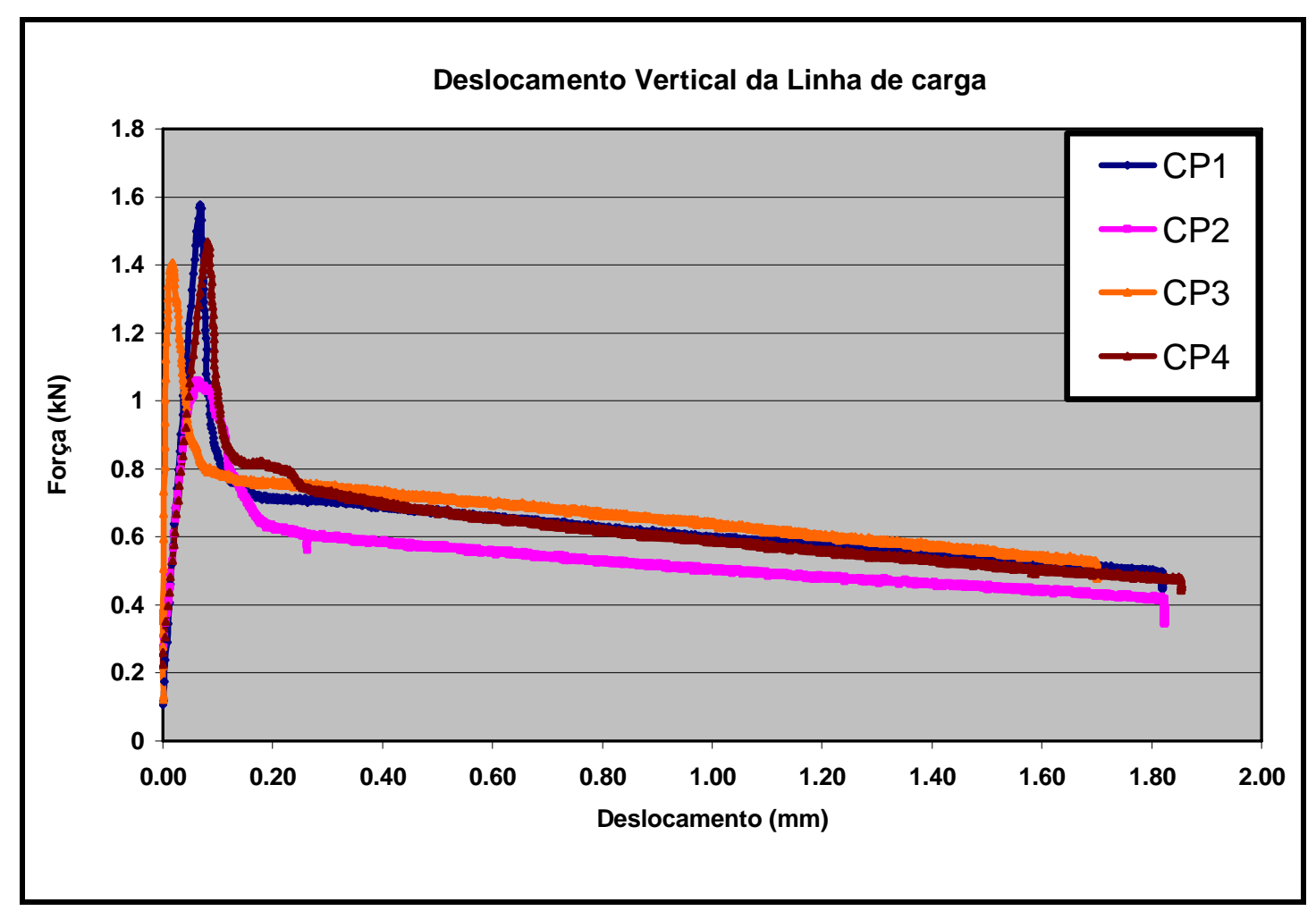

Figura 5.55: Curvas de deslocamento vertical da linha de carga do compósito. 
Por meio da observação das curvas na Figura 5.55, pode-se verificar o comportamento típico de materiais fibrosos. No presente caso, observa-se que após a carga máxima ocorre uma redução considerável da capacidade portante do elemento, decorrente da propagação da fissura. Entretanto, a deformabilidade do corpo-de-prova estende-se a níveis de deslocamento consideravelmente elevados. Em decorrência do comportamento relativamente uniforme obtido no grupo de ensaios, pode-se supor que as fibras tenham sofrido escorregamento na região da fissura, eventualmente em decorrência do comprimento das mesmas. Tendo em vista os baixos valores de módulo de elasticidade apresentados pelo compósito, comparativamente ao módulo de elasticidade das fibras, uma queda tão acentuada na resistência, após a propagação da fissura, não era esperada.

Para cada corpo-de-prova foram calculadas as tensões na fase elástica e as tensões residuais para cada uma dos deslocamentos pré-estabelecidos. Estes valores são apresentados na Tabela 5.12.

Tabela 5.12: Tensões médias para o ensaio de tenacidade flexional.

\begin{tabular}{|l|c|c|}
\hline \multicolumn{1}{|c|}{ Média dos CP's } & MPa & Contribuição da Fibra(\%) \\
\hline Tensão Limite de Proporcionalidade $f_{f c t, L}:$ & 5.064 & 0.00 \\
\hline Tensão Flexional Residual 1 $-f_{R, 1}:$ & 2.586 & 51.07 \\
\hline Tensão Flexional Residual 2 $-f_{R, 2}:$ & 2.271 & 44.84 \\
\hline Tensão Flexional Residual 3 $-f_{R, 3}:$ & 2.007 & 39.64 \\
\hline Tensão Flexional Residual 4 $-f_{R, 4}:$ & 1.718 & 33.93 \\
\hline
\end{tabular}

Por meio dos valores apresentados na Tabela 5.12, pode-se verificar que as contribuições das fibras na resistência do compósito variam de aproximadamente 50\%, para baixos níveis de deslocamento da linha de carga, até 30\% para níveis maiores de deslocamentos verticais.

Cabe aqui ressaltar que os ensaios de fraturamento conseguem mostrar adequadamente o aspecto qualitativo da interação fibra-matriz em situações de solicitações flexionais. Neste caso, a qualidade da interface fibra-matriz poderia e deveria ser melhorada com uma alteração no comprimento das fibras incorporadas ao compósito ou mesclando-se fibras de diferentes tamanhos. No caso desta pesquisa, como as almofadas foram submetidas essencialmente a esforços de compressão, acredita-se que os níveis de contribuição das fibras na resistência do compósito foram adequados. 
Por outro lado, o resultado do conjunto de ensaios realizados nas almofadas evidenciou que as mesmas apresentaram propriedades interessantes para utilização como elemento de apoio. Tendo em vista a sua capacidade de apresentar comportamento resiliente, a sua aptidão de atingir níveis de resistências adequados além de grande capacidade de deformar-se inelasticamente, acredita-se que o compósito possa ser adequadamente utilizado nos casos de estruturas submetidas a esforços repetitivos.

\subsection{Microscopia ótica}

Nesta fase do estudo foram tiradas fotos de uma tira da porção central de uma almofada ensaiada e outra não ensaiada do compósito, para que se pudesse avaliar se existe algum tipo de padrão de rugosidade superficial proveniente do processo de moldagem destas que seria benéfico para a capacidade de deformação do material.

As figuras 5.56 e 5.57 trazem as fotos ampliadas de parte da tira retirada das almofadas, onde observa-se a diferença nos padrões de forma superficial das almofadas.

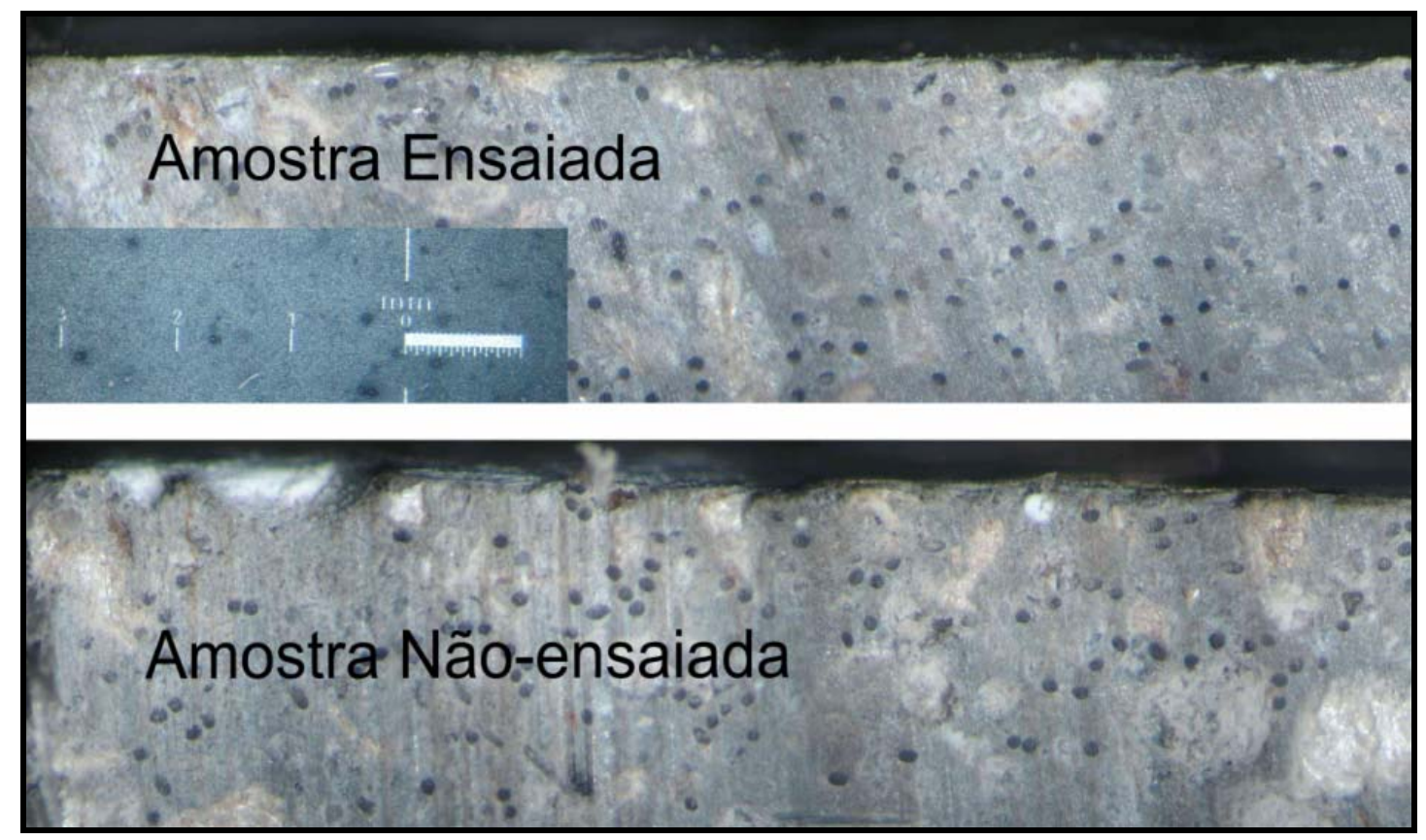

Figura 5.56: Foto de uma das extremidades da superfície das almofadas do compósito. 


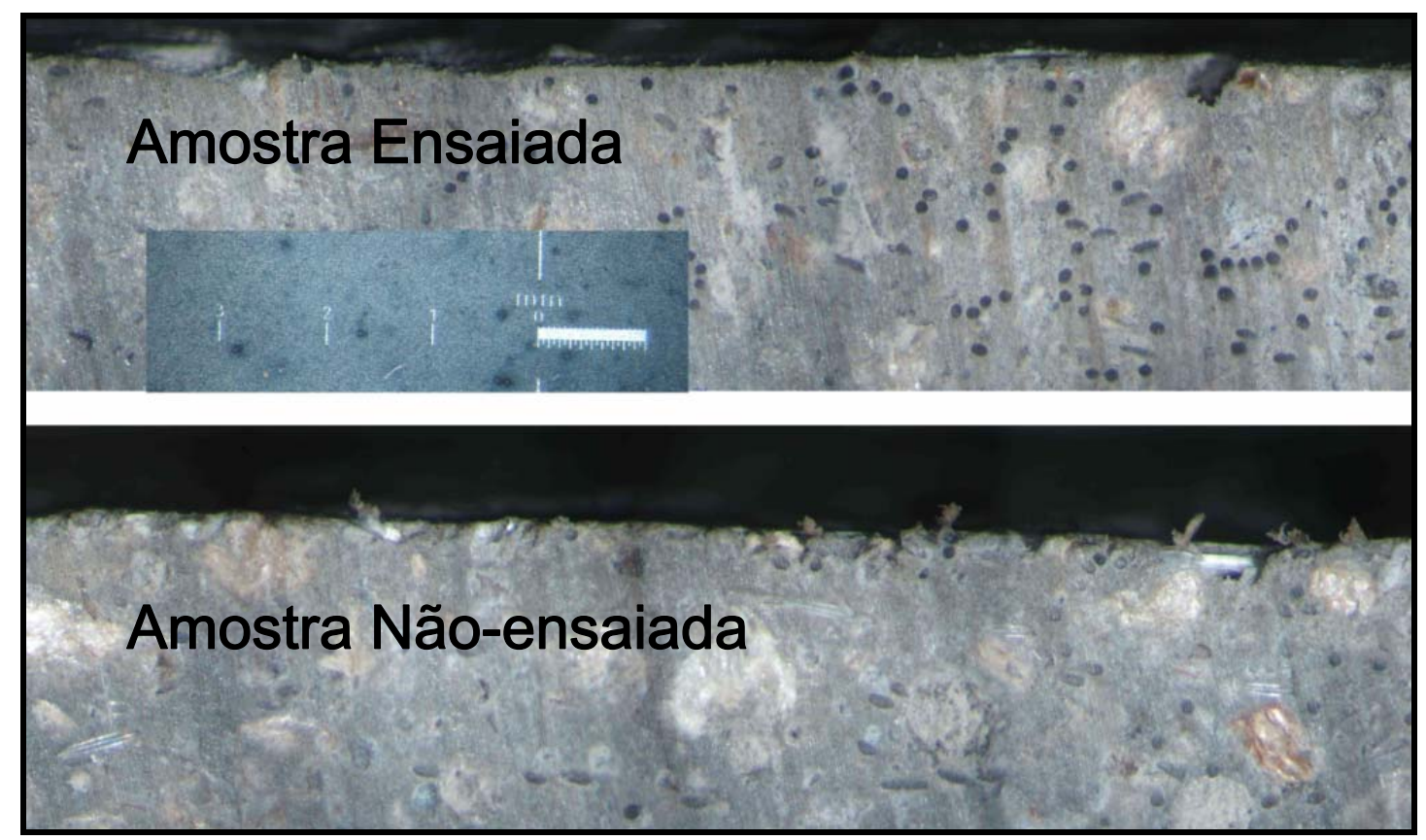

Figura 5.57: Foto da região central da superfície das almofadas do compósito.

A ordem das fotos da Figura 5.57 segue a ordem das fotos da Figura 5.56, sendo apresentadas primeiramente as almofadas ensaiadas e na seqüência as almofadas não ensaiadas. Na Figura 5.56 foi introduzida uma escala para se verificar a ampliação utilizada. A ampliação do microscópio ótico utilizada nas fotos foi de 25x, mas a obtenção das fotos foi realizada por meio de máquina fotográfica digital e, a soma da ampliação da máquina digital pode ter causado algumas distorções nessa ampliação.

Para as almofadas não-ensaiadas observa-se um padrão maior de imperfeições superficiais, fato que, observando-se as fotos das almofadas ensaiadas temos uma mostra de maior acomodação devido à deformação desta proveniente do ensaio realizado.

Este estudo foi realizado da maneira mais simples possível, sem grandes requintes de aparelhagem, portanto, só podemos ver uma tendência de acomodação dessas imperfeições provenientes do processo de moldagem das placas. Estas fotos reforçam a hipótese de que essas imperfeições ajudam no processo de acomodação das peças prémoldadas na região da ligação, mas não podem ser conclusivas para esta afirmação, sendo necessários ensaios específicos focando o processo de produção das almofadas para que se possam fazer afirmações acerca desta hipótese. 


\section{Considerações finais e conclusões}

A partir dos resultados obtidos através das séries ensaios realizados nesta pesquisa, pode-se concluir que:

a) Com relação ao módulo de elasticidade e rigidez das almofadas, obteve-se um material com valores realmente reduzidos. Em se tratando de módulo de elasticidade dos corpos-de-prova, os valores obtidos encontram-se com valores da ordem de 50 a $60 \%$ do valor de uma argamassa de cimento convencional de referência e, próximos aos valores obtidos com as fibras de PVA e vidro da pesquisa anterior. Pode-se assim constatar que, não ocorrem grandes mudanças com a utilização da fibra de polipropileno. Para a rigidez das almofadas, obteve-se um material com valores próximos aos da pesquisa anterior e, sendo estes apenas cinco a seis vezes maiores que para almofadas de policloropreno, evidenciando a capacidade de deformação do compósito. O custo de uma almofada do compósito é bem inferior ao custo de uma almofada de policroropreno, sendo o compósito, uma alternativa econômica para ser utilizado nas ligações em que este pode ser empregado.

b) Na busca de uma relação entre a quantidade de vermiculita a ser incorporada e a deformabilidade do material, os ensaios mostraram uma indicação de qual traço a ser utilizado. O conjunto de resultados mostrou que o traço que apresenta as melhores características para ser utilizado como elemento de apoio é o V10PP4L30 (traço em massa - 1:0,3:0,3:0,1 - cimento:areia:látex:água, sendo que 10\% da massa de areia é substituída por vermiculita, são introduzidos $4 \%$ de fibra de polipropileno e $1 \%$ de superplastificante), seguindo a mesma linha de conclusões da pesquisa anterior.

c) O material apresentou capacidade resiliente, o que pode ser observado nos resultados dos ensaios de carregamento cíclico, onde as rigidezes do material submetido à 
carregamento monotônico se mostraram próximas às rigidezes do último ciclo de carga deste ensaio repetitivo. O material também apresentou uma parcela de recuperação elástica de suas propriedades onde, após certa deformação inicial, a rigidez do compósito permanece constante, mesmo para um nível de tensão da ordem de 20MPa, duas vezes uma tensão normal de serviço para este tipo de almofada de apoio.

d) Nas ligações de concreto pré-moldado, a presença da almofada melhorou o desempenho da ligação quando da existência de imperfeições iniciais nas peças ou a presença de rugosidade entre as superfícies dos elementos pré-moldados da ligação. Para o caso dos elementos perfeitamente lisos o desempenho das almofadas ficou um pouco abaixo do esperado quando esta estava presente, mas deve-se ressaltar que, estes elementos lisos foram moldados com um rigoroso controle de qualidade para garantir a ausência de imperfeições. A existência de qualquer tipo de imperfeição mostra que o desempenho das ligações sem a presença das almofadas sofre uma queda. Para níveis de imperfeição e rugosidades muito elevados, maiores que $1,5 \mathrm{~mm}$, a efetividade das almofadas também é reduzida.

e) A capacidade das almofadas em absorver rotações foi adequada. Os valores de rotações máximas obtidas para o compósito foram da ordem de 25\% maiores que para casos convencionais. As almofadas de $10 \mathrm{~mm}$ de espessura se apresentaram mais adequadas do que as almofadas do mesmo material mas com $20 \mathrm{~mm}$ de espessura. A capacidade de rotação do compósito não se compara à capacidade de elementos elastoméricos, mas, a grande vantagem da utilização das almofadas de argamassa de cimento como elemento de apoio é a economia gerada. Além desta se apresentar com um custo de produção significativamente menor que os aparelhos de apoio comerciais, esta também tem vantagem no que se diz respeito ao custo de manutenção. Sendo o elemento de apoio construído com o mesmo material básico da estrutura, acredita-se que este não necessite de reparos ao longo do tempo, possuindo vida útil da ordem da vida útil da estrutura. 
Como sugestão para trabalhos futuros:

$\checkmark$ Estudar a influência da moldagem no comportamento do compósito, pois se acredita que, as rugosidades que se formam devido ao processo de moldagem utilizado nesta pesquisa ajudem na deformabilidade do material.

$\checkmark$ Estudar a influência do processo de moldagem das placas, mudando-o para o sistema de moldagem do tipo bateria para verificar se a não presença dessa rugosidade superficial afeta em grande escala a capacidade de deformação do material.

$\checkmark$ Estudar os feitos provocados pela utilização de mescla de fibras de $6 \mathrm{~mm}$ de comprimento com fibras de $12 \mathrm{~mm}$ de comprimento, para se melhorar um eventual comportamento à flexão do material.

$\checkmark$ Verificar a metodologia do ensaio de capacidade de rotação de apoio, estudando-se possíveis modificações no ensaio, principalmente a modificação do sistema de distribuição das forças à chapa metálica, podendo-se assim, verificar de uma maneira mais confiável e simples a capacidade de rotação do compósito. 



\section{Referências Bibliográficas}

AFRIDI, M.U.K.(1995). Water retention and adhesion of powdered and aqueous polymer modified mortars. Cement and Concrete Composites. Vol.17, n.4, p.113-8.

AGOPYAN, V. (1993). O emprego de materiais fibrosos na construção civil. In. SIMPÓSIO INTERNACIONAL SOBRE MATERIAIS REFORÇADOS COM FIBRAS PARA CONSTRUÇÃO CIVIL. São Paulo, 1993. Anais. Epusp. p. 11-25.

AMERICAN CONCRETE INSTITUTE - ACI. Guide for use of Polymers in Concrete. ACI Committee 548. Manual concrete of pratice, Part 5, Detroit, 1993.

AMERICAN CONCRETE INSTITUTE (1995). ACI 548.3R. State-of-the-art report on polymer- modified concrete. Detroit, ACI, 1995.

ASSOCIAÇÃO BRASILEIRA DE NORMAS TÉCNICAS. Argamassas e concretos - determinação da resistência à tração na compressão diametral de corpos-de-prova cilíndricos: método de ensaio, NBR 7222/1994, Rio de Janeiro.

ASSOCIAÇÃO BRASILEIRA DE NORMAS TÉCNICAS. Ensaio de cimento Portland: método de ensaio, NBR 7215/1996, Rio de Janeiro.

ASSOCIAÇÃO BRASILEIRA DE NORMAS TÉCNICAS. Ensaio de compressão de corpos-de-prova cilíndricos de concreto: método de ensaio, NBR 5739/1994, Rio de Janeiro.

ASSOCIAÇÃO BRASILEIRA DE NORMAS TÉCNICAS. Projeto de estruturas de concreto, NBR 6118/2003.

BALAGURU, P.N.; SHAH, S.P. (1992). Fiber Reinforced cement composites. New York: McGraw-Hill.

BALDISSERA, A. (2006). Estudo experimental de uma ligação viga-pilar de concreto pré-moldado parcialmente resistente a momento fletor. 149f. Mestrado (Engenharia de Estruturas) - Escola de Engenharia de São Carlos, Universidade de São Paulo, 2006. 
BALLISTA, L. P. Z. (2003). Avaliação de algumas propriedades de concretos estruturais com agregados graúdos reciclados modificados com látex estirenobutadieno. Dissertação de Mestrado. Escola de Engenharia de São Carlos. USP. 152p. São Carlos, 2003.

BANTHIA, N.; NADAKUMAR, N. (2003). Crack growth resistance of hibrid fiber reinforced cement composites. Cement \& Concrete Composites, v.25, p. 3-9.

BARBOSA, A.S.R. (2002). Comportamento de juntas de argamassa solicitadas à compressão na ligação entre elementos pré-moldados. 154f. Doutorado (Engenharia de Estruturas) - Escola de Engenharia de São Carlos, Universidade de São Paulo, 2002.

BARTOS, P. (1992). Performance parameters of fibre reinforced cement based materials. In REINHARDT, H.W.; NAAMAN, A. E. (Ed.) High Performance Fiber Reinforced Cement Composites. London, Rilem, 1992. p. 431-440.

BENTUR, A.; MINDESS, S. (1990). Fibre Reinforced Cementitious Composites. London, Elsevier. p. 449. 1990.

BENTUR, A.; MINDESS, S.; DIAMOND, S. (1985c). Pull out process in steel fiber reinforced cement. The International Journal of Cement Composites and Lightweight Concrete. V.7, n. 1, p. 29-37, Feb. 1985c.

BENTUR, A.; MINDESS, S.; VONDRAN, G. (1989). Bonding in polypropylene fibre reinforced concretes. The International Journal of Cement Composites and Lightweight Concrete. 11(3). p. 153-58. 1989.

BIJEN, J. (1993). Improved mechanical properties of glass fiber reinforced cement by polymer modification. Anais do simpósio internacional sobre materiais reforçados com fibras para construção civil. EPUSP. São Paulo, 1993.

CHAVES, A. L. O. Polímeros: subsídios para utilização na construção civil. $210 f$. Mestrado (Tecnologia do Ambiente Construtivo) - Escola de Engenharia de São Carlos, Universidade de São Paulo, 1999.

CHOdOUNSKY, M. A.; BINA, P. Concretos Poliméricos. In: 39a Reunião do Ibracon, São Paulo, 1997. Anais. Vol1, p.297-310.

CURRIE, B.; GARDINER, T. (1989). Bond between polypropylene fibers and cement matrix. The International Journal of Cement Composites and Lightweight Concrete. V. 11, n. 1, p. 3-9, Feb. 1989.

EL DEBS, M.K. (2000). Concreto pré-moldado: fundamentos e aplicações. EESC USP, São Carlos, 2000. 465p. 
EL DEBS, M.K; BARBOZA , A.S.R; MIOTTO, A.M.M. (2003). Development of material to be used as bearing pad in precast concrete connections. Strucut Concr, 2003;4(4): 185-93.

FELDMAN, D. (1989). Polimeric building materials. New York. Elsevier.

FERREIRA JR.; S. (1997). Concretos especiais para pavimentos: Uso do látex, microssílica e fibras de aço. São Paulo, ABCP. Publicação ET-96, 1997.

FOLIC, R,J.; RADONJANIN, V.S. (1998). Experimental research on polymer modified concrete. ACI Materials Journal, v.95, n.4, p.463-69, 1998.

GODOY, E.H.P.; BARROS, M.B. (1997). A avaliação e desempenho dos sistemas de impermeabilização com argamassas poliméricas. In: SIMPÓSIO BRASILEIRO DE IMPERMEABILIZAÇÃO, 10., São Paulo. Anais, p.206-18.

GOMES, C. E. M. (2000). Análise de algumas proriedades do concreto reforçado com fibras de aço (CRFA) com adição de sílica ativa e do látex estireno-butadieno. 72 f. Mestrado (Tecnologia do Ambiente Construído) - Escola de Engenharia de São Carlos, Universidade de São Paulo, 2000.

JIANG, W.; ROY, D. M. (1992). Mechanical behaviour of advanced cementitious materials. 9th International Congress on the Chemistry of Cement. p. 268-74. 1992.

KATTAR, J.E.; ALMEIDA, N.J. (1999). Cimento Portland. Publicação da Holdercim do Brasil. São Paulo, 1999.

KUHLMANN, L.A. (1987). Application of styrene-butadiene latx modified concrete. Concrete International, v.4, n.3, p.48-53, Dec. 1987.

MANO, E.B. (1985). Introdução a polímeros. Ed. Edgard Blücher Ltda. $4^{a}$ Edição. São Paulo, 1985.

MEHTA, P. K. \& MONTEIRO, P.J.M (1994). Concreto: estrutura, propriedades e materiais. Editora PINI. São Paulo, 1994.

MINDESS, S.; BANTHIA, N. (1994). Fiber reinforced cementitious composites: current practice and future prospects. In. Concrete Technology - past, present and future. V. Mohan Malhotra Symposium. Proceedings... Detroit: ACI. p. 417-46.

MIOTTO, A.M. (2002). Ligações viga-pilar de estruturas de concreto pré-moldado com ênfase ao estudo da deformabilidade ao momento fletor. 234f. Doutorado (Engenharia de Estruturas) - Escola de Engenharia de São Carlos, Universidade de São Paulo, 2002. 
MONTEDOR, L.M. (2004). Desenvolvimento de compósito a ser utilizado como almofada de apoio nas ligações entre elementos pré-moldados. 144f. Mestrado (Engenharia de Estruturas) - Escola de Engenharia de São Carlos, Universidade de São Paulo, 2004.

OHAMA, Y. (1987). Principle of latex modification and some typical properties of latex-modified mortars and concretes. ACI Materials Journal, n. 84, p. 511-518, 1987.

OHAMA, Y. (1991). Pore size distribuition and oxygen diffusion resistance of polymer-modified mortars. Cement and Concrete Research. Vol. 21, pp. 309-315.

OHAMA, Y. (1998). Polymer-based admixtures. Cement and concrete composites. Ed. 20. Elsevier science. 1998.

PERUZZI, A.P. (2002). Comportamento das fibras de vidro convencionais em matriz de cimento Portland modificada com látex e adição de sílica ativa. 96 f. Dissertação de Mestrado. Escola de Engenharia de São Carlos. Universidade de São Paulo, 2002.

RAY, I. et al. (1995). Effect of latex and superplasticiser on Portland cement mortar in the hardened state. Cement and Concrete Composites, v. 17, p. 9-21.

RILEM TC 162-TDF (2002): Test and Design methods for steel fibre reinforced concrete, Materials and Strucutures/Matériaux et Constructions, Vol 35, November 2002, pp579-582.

ROSSIGNOLO, J. A. (1999). Propriedades da argamassa de cimento Portland modificada com látex estireno-butadieno para revestimento de fachadas. Dissertação (Mestrado). Escola de Engenharia de São Carlos. USP. 107p. São Carlos, 1999.

ROSSIGNOLO, J. A. (2003). Concreto leve de alto desempenho modificado com SB para Pré-Fabricados esbeltos - dosagem, produção, propriedades e micro-estrutura. 211p. Tese de Doutorado (Ciência e Engenharia de Materiais). Escola de Engenharia de São Carlos, Instituto de Física de São Carlos e Instituto de Química de São Carlos. Universidade de São Paulo, 2003.

ROSSIGNOLO, J. A.; AGNESINI, M.V.C. (2000). Influência do tipo de cura nas propriedades mecânicas dos Microconcretos Leves de Alto-desempenho Modificados com Polímero para Pré-fabricados de pequena espessura. In: XXIX JORNADAS SUDAMERICANAS DE INGENIERIA ESTRUCTURAL, 2000, Montevidéu URUGUAI. p. 01-08. 
SAVASTANO JR., H. (1994). Materiais reforçados com fibras: correlação entre a zona de transição fibra-matriz e as propriedades mecânicas. São Paulo: Instituto de Pesquisas Tecnológicas (IPT) - Pini, 1994. - (Publicação IPT 2158 - Boletim 67).

SHAH, S. P. (1991). Do fibers increase the tensile strength of cement-based matrixes?. ACI Materials Journals. 88(6). p. 595-602. 1991.

SHAKER, F. A. et al. (1997). Durability of styrene-butadiene latex mofified concrete. Cement and Concrete Research, v. 27, n. 5, p. 711-720.

SILVA, I. J. (1996). Contribuição ao estudo da utilização da resina poliuretana a base de óleo de mamona na Construção Civil. Dissertação (Mestrado). Escola de Engenharia de São Carlos, Universidade de São Paulo.

SOUZA, A. (2006). Comportamento de elementos pré-moldados de concreto com ligações semi-rígidas. 99 f. Dissertação (Mestrado) - Universidade Federal de São Carlos. São Carlos, 2006.

STORTE, M. (1991). Látex estireno-butadieno: aplicação em concretos de cimento e polímero. Dissertação de Mestrado. Escola Politécnica da USP. São Paulo, 1991.

SWAMY, R. N. (1992). Structural implications of high performance fibre cement composites. In REINHARDT, H.W.; NAAMAN, A. E. (Ed.) High Performance Fiber Reinforced Cement Composites. London, Rilem, 1992. p. 529-543.

TEZUKA, Y. (1988). Concreto de cimento e polímero. São Paulo, ABCP, 1988.

TEZUKA, Y. (1989). Concreto Armado com Fibras. São Paulo, ABCP, 1989.

WALTERS, G. (1987). What are latexes?. Concrete International, v.9, n.12, p.44-7, Dec.

WALTERS, G. (1988). Látex hydraulic cement additives. Transportation Research Record. n.1204, p. 71-6.

WALTERS, G. (1990). Comparasion of latex-modiefied Portland cement mortars. ACI Materials Journal, pp. 371-377, nº 4, Vol. 87, Jul./Ag. 